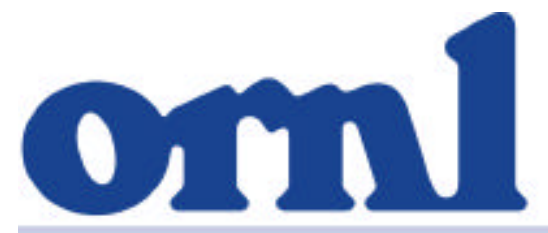

OAK RIDGE NATIONAL LABORATORY

LO C K HEED MARTIN

\section{Kinetics Parameters of VVER-1000 Core with 3 MOX Lead Test Assemblies To Be Used for Accident Analysis Codes}

\author{
A. M. Pavlovitchev \\ A. A. Gorokhov \\ V. K. Ivanov \\ Y. A. Styrin
}

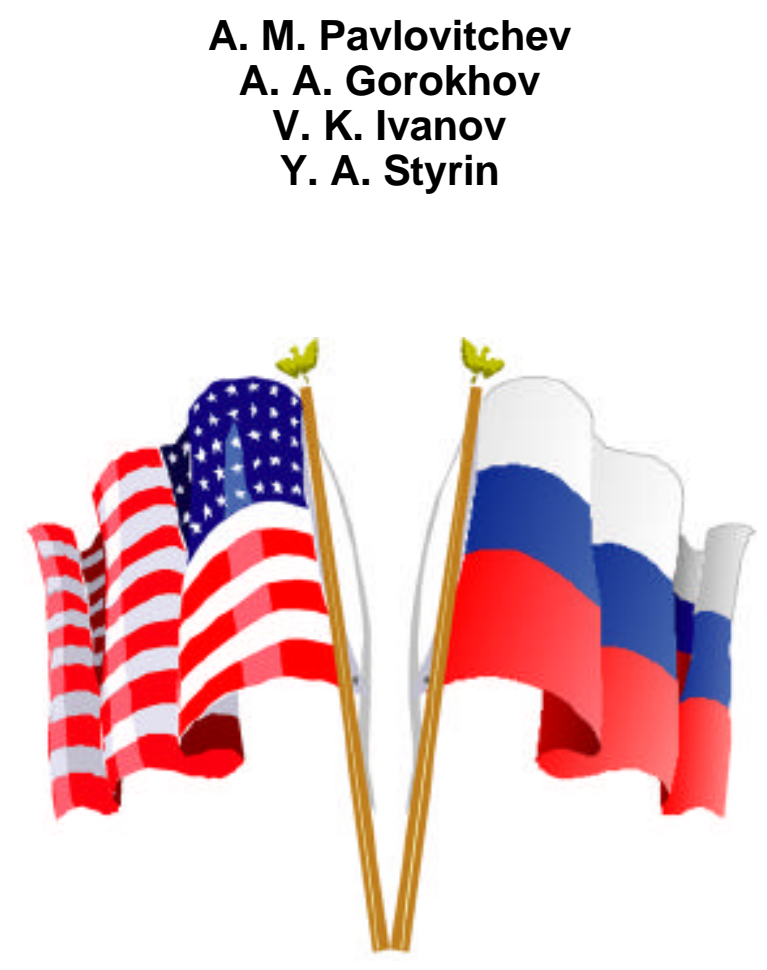

Fissile Materials Disposition Program 
Available electronically from the following source:

Web site www.doe.gov/bridge

Reports are available in paper to the public from the following source.

\author{
U.S. Department of Commerce \\ National Technical Information Service \\ 5285 Port Royal Road \\ Springfield, VA 22161 \\ Telephone 1-800-553-6847 \\ TDD 703-487-4639 \\ Fax 703-605-6900 \\ E-mail orders@ntis.fedworld.gov \\ Web site www.ntis.gov/ordering.htm
}

Reports are available in paper to U.S. Department of Energy (DOE) employees, DOE contractors, Energy Technology Data Exchange (ETDE) representatives, and International Nuclear Information System (INIS) representatives from the following source.

Office of Scientific and Technical Information

P.O. Box 62

Oak Ridge, TN 37831

Telephone 865-576-8401

Fax 865-576-5728

E-mail reports@adonis.osti.qov

\begin{abstract}
This report was prepared as an account of work sponsored by an agency of the United States Government. Neither the United States Government nor any agency thereof, nor any of their employees, makes any warranty, express or implied, or assumes any legal liability or responsibility for the accuracy, completeness, or usefulness or any information, apparatus, product, or process disclosed, or represents that its use would not infringe privately owned rights. Reference herein to any specific commercial product, process, or service by trade name, trademark, manufacturer, or otherwise, does not necessarily constitute or imply its endorsement, recommendation, or favoring by the United States Government or any agency thereof. The views and opinions of authors expressed herein do not necessarily state or reflect those of the United States Government or any agency thereof.
\end{abstract}




\title{
KINETICS PARAMETERS OF VVER-1000 CORE WITH 3 MOX LEAD TEST ASSEMBLIES TO BE USED FOR ACCIDENT ANALYSIS CODES
}

\author{
A. M. Pavlovitchev \\ A. A. Gorokhov \\ V. K. Ivanov \\ Y. A. Styrin
}

Date Published: February 2000

\author{
Prepared by \\ Russian Research Center "Kurchatov Institute" \\ Institute of Nuclear Reactors \\ under subcontract 85B-99398V
}

Funded by

Office of Fissile Materials Disposition

U.S. Department of Energy

Prepared for

Computational Physics and Engineering Division

OAK RIDGE NATIONAL LABORATORY

Oak Ridge, Tennessee 37831

managed by

Lockheed Martin Energy Research Corp.

for the

U.S. Department of Energy

under contract DE-AC05-96OR22464 



\section{Russian Research Center "Kurchatov Institute" \\ Institute of Nuclear Reactors \\ VVER Division}

Joint U.S. / Russian Project to Update, Verify and Validate Reactor Design/Safety Computer Codes Associated with Weapons-Grade Plutonium Disposition in VVER

Reactors

\section{Kinetics Parameters of VVER-1000 Core with 3 MOX Lead Test Assemblies to be used for Accident Analysis Codes}

\section{Report}

General Order 85B-99398V. Work Release 02. P. 99-2

Project Manager

A.M.Pavlovitchev

Executed by

A.A.Gorokhov

V.K.Ivanov

Y.A.Styrin

Moscow 1999 


\section{ACRONYMS}

\begin{tabular}{|c|c|c|}
\hline Russian & & $\begin{array}{l}\text { American } \\
\text { Equivalent }\end{array}$ \\
\hline AZ & emergency (accident) protection & AP \\
\hline AZ-1 & $\begin{array}{l}\text { state with all the control rods fully inserted except of } \\
\text { one the most effective stuck in upper position }\end{array}$ & AP-1 \\
\hline AKNP & Source Range Channel & \\
\hline APN & Safety Injection Pump & \\
\hline ARM & Automated Power Regulator & \\
\hline ASP & Emergency Diesel Generators (Loading Program) & \\
\hline ATWS & Anticipated Transient Without Scram & ATWS \\
\hline $\mathrm{BOC}$ & Beginning Of fuel Cycle & $\mathrm{BOC}$ \\
\hline BPR & Burnable Poison Rod & BPR \\
\hline BZOK & Rapid Cut-off Isolating Valve & \\
\hline BRU-A & Atmospheric Steam Dump (PG Relief Valves) & \\
\hline BRU-K & Condenser Steam Dump (PG Relief Valves) & \\
\hline \multirow[t]{5}{*}{ BShU } & Control Room Of the Unit & \\
\hline & Critical Heat Flux & $\mathrm{CHF}$ \\
\hline & all the control rods in upper position & CRU \\
\hline & all the control rods inserted & CRD \\
\hline & Control Rod Drive Mechanism & CRDM \\
\hline VKS & Reactor Upper Mixing Chamber & \\
\hline VPEN & Auxiliary Feedwater Electrically Driven Pump & \\
\hline VRK & Reactor Internal Control System & \\
\hline DNBR & Departure from Nucleate Boiling Ratio & DNBR \\
\hline DTC & Doppler Temperature Coefficient & DTC \\
\hline EFPD & Effective Full Power Day & EFPD \\
\hline EOC & End Of fuel Cycle & EOC \\
\hline FGR & Fission Gas Release & FGR \\
\hline FP & Fission Products & $\mathrm{FP}$ \\
\hline $\mathrm{GE}(\mathrm{YT})$ & Hydro-tank of SAOZ system (passive part of SAOZ) & $\mathrm{AC}$ \\
\hline $\mathrm{GO}$ & Containment & \\
\hline GPZ & Main Steam Valve & \\
\hline GZK & Primary Cooling Circuit & \\
\hline GZN & Primary Cooling Pump & RCP \\
\hline GZT & Main Circulation Pipeline & \\
\hline IPU & Impulse protection unit & \\
\hline ISA & Initial Event of an Accident & \\
\hline KD & Pressurizer & \\
\hline $\mathrm{KI}$ & Kurchatov Institute & $\mathrm{KI}$ \\
\hline LOCA & Loss Of Coolant Accident & LOCA \\
\hline
\end{tabular}


RUSSIAN RESEARCH CENTER KURCHATOV INSTITUTE

Kinetics Parameters of VVER-1000 Core with 3 MOX Lead Test Assemblies to be used for Accident Analysis Codes

\begin{tabular}{|c|c|c|}
\hline LTA & Lead Test Assembly & LTA \\
\hline LWR & Light Water Reactor & LWR \\
\hline MCL & Minimum Controllable reactor power Level & MCL \\
\hline MDC & Moderator Density Coefficient & MDC \\
\hline MOX & Mixed OXide & MOX \\
\hline MTC & Moderator Temperature Coefficient & MTC \\
\hline NKS & Reactor Bottom Mixing Chamber & \\
\hline NPP & Nuclear Power Plant & NPP \\
\hline OR & Regulatory Body (Control Rod) & CR \\
\hline PVD & Intermediate High Pressure Heater & \\
\hline PG & Steam Generator & SG \\
\hline PK & Relief Valve or Safety Valve & \\
\hline PZ-1 & 1st-level Preventive Protection & \\
\hline PZ-2 & 2nd-level Preventive Protection & \\
\hline PND & Intermediate Low Pressure Heater & \\
\hline PWR & Pressurized-Water Reactor & PWR \\
\hline $\mathrm{P}_{\text {prim }}$ & pressure in primary circuit (in pressurizer) & $\mathrm{P}_{\text {prim }}$ \\
\hline $\mathrm{P}_{\mathrm{sec}}$ & pressure in secondary circuit & $\mathrm{P}_{\mathrm{sec}}$ \\
\hline RIA & Reactivity Initiated Accident & RIA \\
\hline RCT & Repeat Criticality Temperature & RCT \\
\hline ROM & Power Limitation Regulator & \\
\hline RU & Reactor Unit & \\
\hline SAOZ & Emergency Core Cooling System & ECCS \\
\hline SB & Safety System & \\
\hline SLA & Accident Localisation System & \\
\hline SUZ & Reactor Control and Protection System & RPS \\
\hline SVO & Chemical Water Purification System & \\
\hline TQ12 & $\begin{array}{l}\text { High Pressure emergency injection of boron (active part } \\
\text { of SAOZ) }\end{array}$ & \\
\hline TQ14 & $\begin{array}{l}\text { Low Pressure System of core planned and emergency } \\
\text { cooling (active part of SAOZ) }\end{array}$ & \\
\hline TVS, FA & Fuel Assembly & FA \\
\hline TVEL & Fuel Element & \\
\hline TG & Turbine Generator & \\
\hline TPN & Feedwater Turbine Driven Pump & \\
\hline UOX & Uranium Oxide Fuel & UOX \\
\hline VVER & Russian water-water reactor & VVER \\
\hline EGSR & Electric - Hydraulic Regulatory System & \\
\hline
\end{tabular}




\section{EXECUTIVE SUMMARY}

In this document the kinetics parameters intended for use in transient analysis of VVER-1000 core with 3 MOX LTAs are presented. The neutronics parameters of MOX

fuelled core have been calculated by the Russian 3D code BIPR-7A and 2D code PERMAK-A using cell spectrum code TVS-M. 
CONTENTS

INTRODUCTION

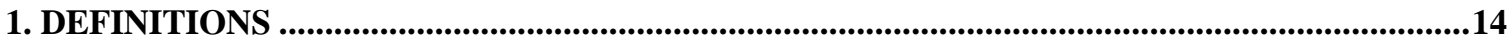

2. KINETICS PARAMETERS IN REFERENCE URANIUM CORE ................................................20

3. KINETICS PARAMETERS IN URANIUM CORE WITH 3 MOX LTAS ...................................21

4. CONSERVATISM ADOPTED FOR TRANSIENT ANALYSIS CALCULATIONS ......................22

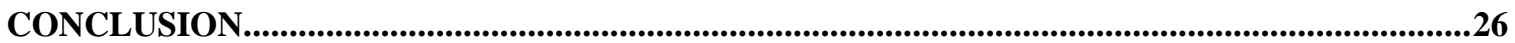

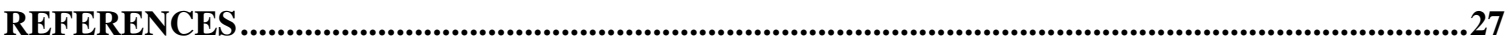


TABLE 1. DEFINITIONS

TABLE 2. NEUTRONICS DATA FOR TRANSIENTS ANALYSIS

TABLE 3. EVOLUTION OF MAIN NEUTRONICS PARAMETERS IN URANIUM REFERENCE CORE . EQUILIBRIUM CYCLE .28

TABLE 4. EVOLUTION OF MAIN NEUTRONICS PARAMETERS. FIRST CYCLE WITH 3 MOX LTAS $100 \%$ PU(4.2-3.0-2.0).

TABLE 5. EVOLUTION OF MAIN NEUTRONICS PARAMETERS. FIRST CYCLE WITH 3 MOX LTAS OF "ISLAND" TYPE: $\{$ PU(3.8-2.8) - U3.7\% $\}$

TABLE 6. EVOLUTION OF MAIN NEUTRONICS PARAMETERS. 2-ND CYCLE WITH 3 MOX

LTAS 100\% PU(4.2-3.0-2.0)

TABLE 7. EVOLUTION OF MAIN NEUTRONICS PARAMETERS. SECOND CYCLE WITH 3 MOX LTAS OF "ISLAND-2" TYPE \{ PU(3.8-2.8) - U3.7\%

TABLE 8. EVOLUTION OF MAIN NEUTRONICS PARAMETERS. 3-D CYCLE WITH 3 MOX

LTAS $100 \%$ PU(4.2-3.0-2.0).

TABLE 9. EVOLUTION OF MAIN NEUTRONICS PARAMETERS. 3-D CYCLE WITH 3 MOX

LTAS OF “ISLAND-2" TYPE $\{$ PU(3.8-2.8) - U3.7\% $\}$

TABLE 10. POWER PEAKING FACTORS ATTAINED DURING FUEL CYCLE.

TABLE 11. CORE SUBCRITICALITY (SCRAM MARGIN) IN DIFFERENT STATES IN THE PROCESS OF SCRAM ACTUATION.

TABLE 12. CONTROL RODS WORTH $\left(\right.$ RO $\left._{\text {AP-1 }}\right)$ FOR URANIUM CORE AND MOX CORES....37

TABLE 13. CORE REACTIVITY IN THE PROCESS OF CONTROL RODS MOVEMENT .........38

TABLE 14. CORE REACTIVITY VERSUS REGULATION GROUP POSITION ...........................39

TABLE 15. CORE REACTIVITY VERSUS COOLANT DENSITY

TABLE 16. CORE REACTIVITY VERSUS CORE POWER AND AVERAGE CORE FUEL TEMPERATURE (DOPPLER EFFECT), PCM.

TABLE 17. ASSEMBLY AXIAL RELATIVE POWER DISTRIBUTION FOR URANIUM REFERENCE CORE. EQUILIBRIUM CYCLE

TABLE 18. AXIAL RELATIVE POWER DISTRIBUTION IN MOX ASSEMBLIES

TABLE 19. MINIMUM EFFECTIVENESS OF REGULATION GROUP VERSUS ITS

TABLE 20. RELATIVE CORE REACTIVITY EVOLUTION IN THE PROCESS OF CONTROL RODS MOVEMENT

TABLE 21. CONSERVATIVE CURVES FOR ASSEMBLY AXIAL POWER DISTRIBUTION....46 
RUSSIAN RESEARCH CENTER KURCHATOV INSTITUTE

Kinetics Parameters of VVER-1000 Core with 3 MOX Lead Test Assemblies to be used for Accident Analysis Codes

TABLE 22. CONSERVATIVE CURVE FOR CORE REACTIVITY VERSUS COOLANT

DENSITY .47

TABLE 23. CONSERVATIVE CURVE FOR LINEAR FUEL PIN POWER .....................................48

TABLE 24. DECAY RATES OF DELAYED NEUTRONS 49 
FIG.1. EQUILIBRIUM LOADING PATTERN FOR URANIUM REFERENCE CORE WITH BORON

BPRS. CORE $60^{\circ}$ SECTOR

FIG.2. ßEFF EVOLUTION DURING CORE FUEL CYCLE FOR URANIUM AND MOX CORES ...51

FIG.3. CORE REACTIVITY EVOLUTION IN THE PROCESS OF CONTROL RODS MOVEMENT FOR URANIUM AND MOX CORES IN BOC.

FIG.3A. CORE REACTIVITY EVOLUTION IN THE PROCESS OF CONTROL RODS MOVEMENT

FOR URANIUM AND MOX CORES IN EOC.

FIGURE 4. CORE REACTIVITY VERSUS REGULATING GROUP POSITION IN BOC .54

FIGURE 4A. CORE REACTIVITY VERSUS REGULATING GROUP POSITION IN EOC 55

FIG.5. CORE REACTIVITY VERSUS COOLANT DENSITY 56

FIG.6. CORE REACTIVITY VERSUS FUEL TEMPERATURE IN BOC .57

FIG.6A. CORE REACTIVITY VERSUS FUEL TEMPERATURE IN EOC .58

FIG.7. ASSEMBLY AXIAL POWER DISTRIBUTION FOR URANIUM REFERENCE CORE. EQUILIBRIUM CYCLE

FIG.7A. AXIAL POWER DISTRIBUTION IN MOX LTAS

FIG.8. ASSEMBLY-BY-ASSEMBLY BURNUP, POWER AND TEMPERATURE DROPS DISTRIBUTIONS. EQUILIBRIUM CYCLE FOR URANIUM REFERENCE CORE WITH BORON BPRS.CORE 60 $\mathrm{SECTOR}$

FIG.9. ASSEMBLY-BY-ASSEMBLY MAXIMUM LINEAR PIN POWER DISTRIBUTION IN BOC. EQUILIBRIUM CYCLE FOR URANIUM REFERENCE CORE WITH BORON BPRS.CORE 60 SECTOR.

FIG.10. ASSEMBLY-BY-ASSEMBLY MAXIMUM LINEAR PIN POWER DISTRIBUTION IN EOC. EQUILIBRIUM CYCLE FOR URANIUM REFERENCE CORE WITH BORON BPRS.CORE 60 SECTOR.

FIG.11. PIN-BY-PIN POWER DISTRIBUTION IN THE MOST POWERED ASSEMBLY IN BOC. EQUILIBRIUM CYCLE FOR URANIUM REFERENCE CORE WITH BORON BPRS.

FIG.12. PIN-BY-PIN POWER DISTRIBUTION IN THE MOST POWERED ASSEMBLY IN EOC. EQUILIBRIUM CYCLE FOR URANIUM REFERENCE CORE WITH BORON BPRS..................65

FIG.13. CONTROL RODS GROUPING .66 
FIG.15. ASSEMBLY-BY-ASSEMBLY POWER DISTRIBUTION. FIRST CYCLE WITH 3 MOX

LTAS $100 \%$ PU (4.2-3.0-2.0)

FIG.16. ASSEMBLY-BY-ASSEMBLY BURNUP DISTRIBUTION. FIRST CYCLE WITH 3 MOX

LTAS $100 \%$ PU (4.2-3.0-2.0)

FIG.17. ASSEMBLY-BY-ASSEMBLY TEMPERATURE DROP DISTRIBUTION. FIRST CYCLE

WITH 3 MOX LTAS 100\%PU (4.2-3.0-2.0)

FIG.18. ASSEMBLY-BY-ASSEMBLY MAXIMUM LINEAR PIN POWER DISTRIBUTION IN BOC.

FIRST CYCLE WITH 3 MOX LTAS 100\%PU (4.2-3.0-2.0)...

FIG.19. ASSEMBLY-BY-ASSEMBLY MAXIMUM LINEAR PIN POWER DISTRIBUTION IN EOC.

FIRST CYCLE WITH 3 MOX LTAS 100\%PU (4.2-3.0-2.0)...

FIG.20. PIN-BY-PIN POWER DISTRIBUTION IN THE MOST POWERED ASSEMBLY IN BOC.

FIRST CYCLE WITH 3 MOX LTAS 100\%PU (4.2-3.0-2.0)

FIG.21. PIN-BY-PIN POWER DISTRIBUTION IN THE MOST POWERED ASSEMBLY IN EOC.

FIRST CYCLE WITH 3 MOX LTAS 100\%PU (4.2-3.0-2.0)

FIG.22. PIN-BY-PIN POWER DISTRIBUTION IN MOX LTA IN BOC. FIRST CYCLE WITH 3 MOX

LTAS $100 \%$ PU (4.2-3.0-2.0) .

FIG.23. PIN-BY-PIN POWER DISTRIBUTION IN MOX LTA IN EOC. FIRST CYCLE WITH 3 MOX

LTAS 100\%PU (4.2-3.0-2.0) .76

FIG.24. ASSEMBLY-BY-ASSEMBLY POWER DISTRIBUTION. FIRST CYCLE WITH 3 MOX LTAS OF "ISLAND” TYPE (PU3.8-2.8, U-3.7) .77

FIG.25. ASSEMBLY-BY-ASSEMBLY BURNUP DISTRIBUTION. FIRST CYCLE WITH 3 MOX LTAS OF "ISLAND" TYPE (PU3.8-2.8, U-3.7) . .78

FIG.26. ASSEMBLY-BY-ASSEMBLY TEMPERATURE DROP DISTRIBUTION. FIRST CYCLE WITH 3 MOX LTAS OF "ISLAND" TYPE (PU3.8-2.8, U-3.7) . .79

FIG.27. ASSEMBLY-BY-ASSEMBLY MAXIMUM LINEAR POWER DISTRIBUTION IN BOC. FIRST CYCLE WITH 3 MOX LTAS OF “ISLAND” TYPE (PU3.8-2.8-U3.7) ..

FIG.28. ASSEMBLY-BY-ASSEMBLY MAXIMUM LINEAR POWER DISTRIBUTION IN EOC. FIRST CYCLE WITH 3 MOX LTAS OF “ISLAND” TYPE (PU3.8-2.8-U3.7) .81

FIG.29. PIN-BY-PIN POWER DISTRIBUTION IN THE MOST POWERED ASSEMBLY IN BOC. FIRST CYCLE WITH 3 MOX LTAS OF “ISLAND” TYPE (PU3.8-2.8, U-3.7. .82

FIG.30. PIN-BY-PIN POWER DISTRIBUTION IN THE MOST POWERED ASSEMBLY IN EOC. FIRST CYCLE WITH 3 MOX LTAS OF “ISLAND” TYPE (PU3.8-2.8, U-3.7) ... 
FIG.31. PIN-BY-PIN POWER DISTRIBUTION IN MOX LTA IN BOC. FIRST CYCLE WITH 3 MOX LTAS OF “ISLAND” TYPE (PU3.8-2.8, U-3.7)

FIG.32. PIN-BY-PIN POWER DISTRIBUTION IN MOX LTA IN EOC. FIRST CYCLE WITH 3 MOX LTAS OF “ISLAND” TYPE (PU3.8-2.8, U-3.7).

FIG.33. RELOADING SCHEME. SECOND CYCLE WITH 3 MOX LTAS .86

FIG.34. ASSEMBLY-BY-ASSEMBLY POWER DISTRIBUTION. SECOND CYCLE WITH 3 MOX

FIG.35. ASSEMBLY-BY-ASSEMBLY TEMPERATURE DROP POWER DISTRIBUTION. SECOND

FIG.36. ASSEMBLY-BY-ASSEMBLY BURNUP DISTRIBUTION. SECOND CYCLE WITH 3 MOX

FIG.37. ASSEMBLY-BY-ASSEMBLY MAXIMUM LINEAR PIN POWER DISTRIBUTION IN BOC. SECOND CYCLE WITH 3 MOX LTAS 100\%PU (4.2-3.0-2.0).

FIG.38. ASSEMBLY-BY-ASSEMBLY MAXIMUM LINEAR PIN POWER DISTRIBUTION IN EOC. SECOND CYCLE WITH 3 MOX LTAS 100\%PU (4.2-3.0-2.0).

FIG.39. PIN-BY-PIN POWER DISTRIBUTION IN THE MOST POWERED ASSEMBLY IN BOC.

FIG.40. PIN-BY-PIN POWER DISTRIBUTION IN THE MOST POWERED ASSEMBLY IN EOC. SECOND CYCLE WITH 3 MOX LTAS 100\%PU (4.2-3.0-2.0).

FIG.41. PIN-BY-PIN POWER DISTRIBUTION IN MOX LTA IN BOC. SECOND CYCLE WITH 3 MOX LTAS 100\%PU (4.2-3.0-2.0)

FIG.42. PIN-BY-PIN POWER DISTRIBUTION IN MOX LTA IN EOC. SECOND CYCLE WITH 3 MOX LTAS 100\%PU (4.2-3.0-2.0)

FIG.43. ASSEMBLY-BY-ASSEMBLY POWER DISTRIBUTION. SECOND CYCLE WITH 3 MOX LTAS OF "ISLAND” TYPE ( PU3.8-2.8-U3.7).

FIG.44. ASSEMBLY-BY-ASSEMBLY BURNUP DISTRIBUTION. SECOND CYCLE WITH 3 MOX LTAS OF “ISLAND” TYPE ( PU3.8-2.8-U3.7)

FIG.45. ASSEMBLY-BY-ASSEMBLY TEMPERATURE DROP DISTRIBUTION. SECOND CYCLE WITH 3 MOX LTAS OF “ISLAND” TYPE ( PU3.8-2.8-U3.7)

FIG.46. ASSEMBLY-BY-ASSEMBLY MAXIMUM LINEAR PIN POWER DISTRIBUTION IN BOC. SECOND CYCLE WITH 3 MOX LTAS OF “ISLAND” TYPE ( PU3.8-2.8-U3.7)

FIG.47. ASSEMBLY-BY-ASSEMBLY MAXIMUM LINEAR PIN POWER DISTRIBUTION IN EOC. SECOND CYCLE WITH 3 MOX LTAS OF “ISLAND" TYPE ( PU3.8-2.8-U3.7). 100

FIG.48. PIN-BY-PIN POWER DISTRIBUTION IN THE MOST POWERED ASSEMBLY IN BOC. SECOND CYCLE WITH 3 MOX LTAS OF "ISLAND” TYPE ( PU3.8-2.8-U3.7) ............................101

FIG.49. PIN-BY-PIN POWER DISTRIBUTION IN THE MOST POWERED ASSEMBLY IN EOC. SECOND CYCLE WITH 3 MOX LTAS OF “ISLAND” TYPE ( PU3.8-2.8-U3.7 ). 
Kinetics Parameters of VVER-1000 Core with 3 MOX Lead Test Assemblies to be used for Accident Analysis Codes

FIG.50. PIN-BY-PIN POWER DISTRIBUTION IN MOX LTA IN BOC. SECOND CYCLE WITH 3 MOX LTAS OF “ISLAND” TYPE ( PU3.8-2.8-U3.7) 103

FIG.51. PIN-BY-PIN POWER DISTRIBUTION IN MOX LTA IN EOC. SECOND CYCLE WITH 3 MOX LTAS OF “ISLAND” TYPE ( PU3.8-2.8-U3.7 ) . .104

FIG.52. RELOADING SCHEME. THIRD CYCLE WITH 3 MOX LTAS 105

FIG.53. ASSEMBLY-BY-ASSEMBLY POWER DISTRIBUTION. THIRD CYCLE WITH 3 MOX LTAS $100 \%$ PU (4.2-3.0-2.0) 106

FIG.54. ASSEMBLY-BY-ASSEMBLY BURNUP DISTRIBUTION. THIRD CYCLE WITH 3 MOX LTAS $100 \%$ PU (4.2-3.0-2.0)

FIG.55. ASSEMBLY-BY-ASSEMBLY TEMPERATURE DROP DISTRIBUTION. THIRD CYCLE WITH 3 MOX LTAS 100\%PU (4.2-3.0-2.0) 108

FIG.56. ASSEMBLY-BY-ASSEMBLY MAXIMUM LINEAR PIN POWER DISTRIBUTION IN BOC. THIRD CYCLE WITH 3 MOX LTAS 100\%PU (4.2-3.0-2.0). 109

FIG.57. ASSEMBLY-BY-ASSEMBLY MAXIMUM LINEAR PIN POWER DISTRIBUTION IN EOC. THIRD CYCLE WITH 3 MOX LTAS 100\%PU (4.2-3.0-2.0). 110

FIG.58. PIN-BY-PIN POWER DISTRIBUTION IN THE MOST POWERED ASSEMBLY IN BOC. THIRD CYCLE WITH 3 MOX LTAS 100\%PU (4.2-3.0-2.0)

FIG.59. PIN-BY-PIN POWER DISTRIBUTION IN THE MOST POWERED ASSEMBLY IN EOC. THIRD CYCLE WITH 3 MOX LTAS 100\%PU (4.2-3.0-2.0 ).

FIG.60. PIN-BY-PIN POWER DISTRIBUTION IN MOX LTA IN BOC. THIRD CYCLE WITH 3 MOX LTAS 100\%PU (4.2-3.0-2.0)

FIG.61. PIN-BY-PIN POWER DISTRIBUTION IN MOX LTA IN EOC. THIRD CYCLE WITH 3 MOX LTAS 100\%PU (4.2-3.0-2.0)

FIG.62. ASSEMBLY-BY-ASSEMBLY POWER DISTRIBUTION. THIRD CYCLE WITH 3 MOX LTAS OF "ISLAND" TYPE (PU3.8-2.8-U3.7).

FIG.63. ASSEMBLY-BY-ASSEMBLY BURNUP DISTRIBUTION. THIRD CYCLE WITH 3 MOX LTAS OF “ISLAND” TYPE (PU3.8-2.8-U3.7).

FIG.64. ASSEMBLY-BY-ASSEMBLY TEMPERATURE DROP DISTRIBUTION. THIRD CYCLE WITH 3 MOX LTAS OF “ISLAND” TYPE (PU3.8-2.8-U3.7)

FIG.65. ASSEMBLY-BY-ASSEMBLY MAXIMUM LINEAR POWER DISTRIBUTION IN BOC.

THIRD CYCLE WITH 3 MOX LTAS OF “ISLAND” TYPE (PU3.8-2.8-U3.7) .................................118

FIG.66. ASSEMBLY-BY-ASSEMBLY MAXIMUM LINEAR POWER DISTRIBUTION IN EOC. THIRD CYCLE WITH 3 MOX LTAS OF “ISLAND” TYPE (PU3.8-2.8-U3.7).

FIG.67. PIN-BY-PIN POWER DISTRIBUTION IN THE MOST POWERED ASSEMBLY IN BOC. THIRD CYCLE WITH 3 MOX LTAS OF "ISLAND” TYPE ( PU3.8-2.8-U3.7 ) .............................120

FIG.68. PIN-BY-PIN POWER DISTRIBUTION IN THE MOST POWERED ASSEMBLY IN EOC. THIRD CYCLE WITH 3 MOX LTAS OF “ISLAND” TYPE ( PU3.8-2.8-U3.7 ). 
RUSSIAN RESEARCH CENTER KURCHATOV INSTITUTE

Kinetics Parameters of VVER-1000 Core with 3 MOX Lead Test Assemblies to be used for Accident Analysis Codes

FIG.69. PIN-BY-PIN POWER DISTRIBUTION IN MOX LTA IN BOC. THIRD CYCLE WITH 3

MOX LTAS OF “ISLAND” TYPE ( PU3.8-2.8-U3.7 ) ...............................................................122

FIG.70. PIN-BY-PIN POWER DISTRIBUTION IN MOX LTA IN EOC. THIRD CYCLE WITH 3 MOX LTAS OF “ISLAND” TYPE ( PU3.8-2.8-U3.7 ) . 


\section{INTRODUCTION}

The present work is a part of Joint U.S. / Russian Project with Weapons-Grade Plutonium Disposition in VVER Reactor and presents the neutronics calculations of kinetics parameters of VVER-1000 core with 3 introduced MOX LTAs.

MOX LTA design has been studied in [1] for two options of MOX LTA: 100\% plutonium and of "island" type. As a result, zoning i.e. fissile plutonium enrichments in different plutonium zones, has been defined. VVER-1000 core with 3 introduced MOX LTAs of chosen design has been calculated in [2].

In present work, the neutronics data for transient analysis codes (RELAP [3]) has been obtained using the codes chain of RRC "Kurchatov Institute" [5] that is to be used for exploitation neutronics calculations of VVER. Nowadays the 3D assembly-by-assembly code BIPR-7A and 2D pin-by-pin code PERMAK-A, both with the neutronics constants prepared by the cell code TVS-M, are the base elements of this chain.

It should be reminded that in [6] TVS-M was used only for the constants calculations of MOX FAs. In current calculations the code TVS-M has been used both for UOX and MOX fuel constants. Besides, the volume of presented information has been increased and additional explications have been included.

The results for the reference uranium core [4] are presented in Chapter 2.

The results for the core with 3 MOX LTAs are presented in Chapter 3.

The conservatism that is connected with neutronics parameters and that must be taken into account during transient analysis calculations, is discussed in Chapter 4. The conservative parameters values are considered to be used in 1-point core kinetics models of accident analysis codes. 


\section{DEFINITIONS}

\section{Table 1. Definitions}

\begin{tabular}{|c|c|c|c|}
\hline Parameter & Abbreviation & Units & Remarks \\
\hline Calculational system & $\mathrm{CS}$ & & Multi-Assembly or core \\
\hline CS symmetry sector & Sim & & $\begin{array}{l}30 \text { for } 30^{\circ}, \\
60 \text { for } 60^{\circ}, \\
120 \text { for } 120^{\circ} \\
360 \text { for full CS. } \\
\end{array}$ \\
\hline Reactivity of CS & RO & $\mathrm{pcm}$ & $\mathrm{RO}=($ Keff-1)/Keff $* 1 . \mathrm{E} 5$ \\
\hline Calculational volume & Vij & & $\begin{array}{l}\text { Axial fraction } \mathrm{j} \text { of assembly number } \mathrm{i} \text {. } \\
\text { In VVER-1000 calculations, 10-30 axial } \\
\text { fractions of equal volume are usually used. }\end{array}$ \\
\hline Effective multiplication factor of CS & Keff & & \\
\hline Multiplication factor of CS & Ko & & $\begin{array}{l}\text { Relation of neutron generation to neutron } \\
\text { absorption. } \\
\text { For core calculations Ko values are attributed } \\
\text { to Vij }\end{array}$ \\
\hline 3-D power distribution in core & $\mathrm{q}_{\mathrm{ij}}$ & & Power in Vij normalised by average Vij power \\
\hline Volume power peaking factor & $\mathrm{Kv}$ & & Maximum in $\mathrm{q}_{\mathrm{ij}}$ values \\
\hline $\begin{array}{l}\text { Radial position of volume power peaking } \\
\text { factor }\end{array}$ & $\mathrm{N}(\mathrm{Kv})$ or $\mathrm{N}_{\mathrm{K}}$ & & $\begin{array}{l}\text { Number of assembly in calculational core } \\
\text { sector where } \mathrm{Kv} \text { is realised }\end{array}$ \\
\hline $\begin{array}{l}\text { Axial position of volume power peaking } \\
\text { factor }\end{array}$ & $\mathrm{M}(\mathrm{Kv})$ or $\mathrm{N}_{\mathrm{Z}}$ & & Number of axial level where $\mathrm{Kv}$ is realised \\
\hline 3-D burnup distribution in core & BUij & $\mathrm{MWd} / \mathrm{kg}$ & Burnup in Vij. \\
\hline 2-D power distribution in core & $\mathrm{q}_{\mathrm{i}}$ & & $\begin{array}{l}\text { Assembly powers normalised by average } \\
\text { assembly power in core. }\end{array}$ \\
\hline
\end{tabular}


RUSSIAN RESEARCH CENTER KURCHATOV INSTITUTE

Kinetics Parameters of VVER-1000 Core with 3 MOX Lead Test Assemblies to be used for Accident Analysis Codes

\begin{tabular}{|c|c|c|c|}
\hline Radial power peaking factor & $\mathrm{Kq}$ & & Maximum in qi values \\
\hline $\begin{array}{l}\text { Radial position of radial power peaking } \\
\text { factor }\end{array}$ & $\mathrm{N}(\mathrm{Kq})$ or $\mathrm{N}_{\mathrm{K}}$ & & $\begin{array}{l}\text { Number of assembly in calculational core } \\
\text { sector where } \mathrm{Kq} \text { is realised }\end{array}$ \\
\hline Pin linear power & Q1 & $\mathrm{W} / \mathrm{cm}$ & $\begin{array}{l}\text { Pin power for } 1 \mathrm{~cm} \text { of an axial calculational } \\
\text { fraction }\end{array}$ \\
\hline Moment during fuel irradiation & $\mathrm{T}$ & EFPD & \\
\hline 2-D burnup distribution in core & BUi & $\mathrm{MWd} / \mathrm{kg}$ & Average-assembly burnup distribution in core. \\
\hline Average burnup in Uranium assemblies & $\overline{\mathrm{B}}_{\mathrm{U}}$ & $\mathrm{MWd} / \mathrm{kg}$ & \\
\hline Average burnup in MOX assemblies & $\overline{\mathrm{B}}_{\mathrm{MOX}}$ & $\mathrm{MWd} / \mathrm{kg}$ & \\
\hline $\begin{array}{l}\text { Average Boron acid }\left(\mathrm{H}_{3} \mathrm{BO}_{3}\right) \\
\text { concentration in coolant }\end{array}$ & $\begin{array}{l}\mathrm{Cb} \text { or } \\
\mathrm{C}_{\mathrm{H} 3 \mathrm{BO} 3}\end{array}$ & $\begin{array}{l}\mathrm{ppm} \\
\text { or } \mathrm{g} / \mathrm{kg}\end{array}$ & $\begin{array}{l}\mathrm{H}_{3} \mathrm{BO}_{3} \text { fraction in coolant (unit "ppm" means } \\
\text { mg of boron acid in } 1 \mathrm{Kg} \text { of } \mathrm{H}_{2} \mathrm{O} \text { ) }\end{array}$ \\
\hline Critical boron acid concentration in coolant & $\mathrm{Cb}^{\text {crit }}$ & $\begin{array}{r}\text { ppm } \\
\text { or } \mathrm{g} / \mathrm{kg} \\
\end{array}$ & $\mathrm{Cb}\left(\mathrm{C}_{\mathrm{H} 3 \mathrm{BO} 3}\right)$ value ensuring $\mathrm{Keff}=1$ \\
\hline 2-D power distribution in $\mathrm{CS}$ & $\mathrm{q}_{\mathrm{k}}-\mathrm{CS}$ & & $\begin{array}{l}\text { Power of fuel pins normalised by average fuel } \\
\text { pin power in CS. }\end{array}$ \\
\hline $\begin{array}{l}\text { Peaking factor of 2-D power distribution } \\
\text { in CS }\end{array}$ & $\mathrm{K}_{\mathrm{FA}}-\mathrm{CS}$ & & Maximum in $\mathrm{q}_{\mathrm{k}}-\mathrm{CS}$ values \\
\hline 2-D power distribution in assembly & $\mathrm{q}_{\mathrm{k}}$ & & $\begin{array}{l}\text { Power of fuel pins normalised by average fuel } \\
\text { pin power in assembly (in some axial fraction). }\end{array}$ \\
\hline $\begin{array}{l}\text { 3-D power distribution in axial volumes } \\
\text { of fuel pins in core }\end{array}$ & $\mathrm{q}_{\mathrm{ijk}}$ & & $\begin{array}{l}\text { Power of axial volumes of fuel pins normalised } \\
\text { by average power in such volumes over a whole } \\
\text { core }\end{array}$ \\
\hline
\end{tabular}

\footnotetext{
- Boron acid concentration divided by the coefficient 5.72 means natural boron (nat B) concentration. In VVER-1000 calculations the term of boron acid concentration is widely used. Below, $\mathrm{Cb}$ means boron acid concentration if there is no special indication.
} 
RUSSIAN RESEARCH CENTER KURCHATOV INSTITUTE

Kinetics Parameters of VVER-1000 Core with 3 MOX Lead Test Assemblies to be used for Accident Analysis Codes

\begin{tabular}{|c|c|c|c|}
\hline Pin power peaking factor in assembly & Kki & & $\begin{array}{l}\text { Among } q_{k} \text { values for an assembly number } i \text { for a } \\
\text { fraction number } j \text { where maximum } q_{i j} \text { for this } \\
\text { assembly is realised. }\end{array}$ \\
\hline Radial pin power peaking factor & $\mathrm{Kr}$ & & $\max (\mathrm{qi} * \mathrm{Kki})$ \\
\hline $\begin{array}{l}\text { Radial position of radial pin power } \\
\text { peaking factor }\end{array}$ & $\mathrm{N}(\mathrm{Kr})$ or $\mathrm{N}_{\mathrm{K}}$ & & $\begin{array}{l}\text { Number of assembly in calculational core } \\
\text { sector where } \mathrm{Kr} \text { is realised }\end{array}$ \\
\hline 2-D power peaking factor in assembly & $\begin{array}{c}\mathrm{K}_{\mathrm{FA}} \\
\text { (in Russian } \\
\text { exploitation } \\
\text { calculations the } \\
\text { notation } \mathrm{Kk} \text { or } \\
\mathrm{Kk}_{\max } \text { is also } \\
\text { used) }\end{array}$ & & $\begin{array}{l}\text { Maximum relative power of fuel pins } \\
\text { (maximum in } \mathrm{q}_{\mathrm{k}} \text { values) }\end{array}$ \\
\hline $\begin{array}{l}\text { Axial power peaking factor in assembly } \\
\text { or in fuel pin }\end{array}$ & $\mathrm{Kz}$ & & $\begin{array}{l}\text { Maximum relative power of axial volume in } \\
\text { assembly or in fuel pin normalised by average } \\
\text { power in such volumes (in assembly or in fuel pin) }\end{array}$ \\
\hline Total power peaking factor & Ko or $\mathrm{K}_{\text {o-total }}$ & & $\begin{array}{l}\max \left(\mathrm{q}_{\mathrm{ij}} * \mathrm{Kki}\right)=\mathrm{Kr} * \mathrm{Kz} \\
{ }_{\mathrm{ij}}\end{array}$ \\
\hline $\begin{array}{l}\text { Radial position of total power peaking } \\
\text { factor }\end{array}$ & $\begin{array}{l}N\left(K_{\text {o-total }}\right) \text { or } \\
N_{K}\end{array}$ & & $\begin{array}{l}\text { Number of assembly in calculational core } \\
\text { sector where } \mathrm{K}_{\text {o-total }} \text { is realised }\end{array}$ \\
\hline $\begin{array}{l}\text { Axial position of total power peaking } \\
\text { factor }\end{array}$ & $\begin{array}{l}\mathrm{M}\left(\mathrm{K}_{\mathrm{o}-\text { total }}\right) \text { or } \\
\mathrm{N}_{\mathrm{Z}}\end{array}$ & & Number of axial level where $\mathrm{K}_{\mathrm{o} \text {-total }}$ is realised \\
\hline Engineering factor & $\mathrm{K}_{\mathrm{eng}}$ & & $\begin{array}{l}\text { Coefficient taking account of uncertainty of a } \\
\text { hot point (maximum fuel pin local power) } \\
\text { calculations }\end{array}$ \\
\hline 2-D burnup distribution in assembly & BUk & $\mathrm{MWd} / \mathrm{kg}$ & Average-pin burnup distribution in CS. \\
\hline 1-D burnup distribution in fuel pin & BUpin & & $\begin{array}{l}\text { Burnup distribution in concentric zones of } \\
\text { equal volume in fuel pin, normalised by average }\end{array}$ \\
\hline & & & zone burnup. \\
\hline
\end{tabular}


RUSSIAN RESEARCH CENTER KURCHATOV INSTITUTE

Kinetics Parameters of VVER-1000 Core with 3 MOX Lead Test Assemblies to be used for Accident Analysis Codes

\begin{tabular}{|c|c|c|c|}
\hline 1-D power distribution in fuel pin & $\mathrm{q}_{\text {pin }}$ & & $\begin{array}{l}\text { Power distribution in concentric zones of equal } \\
\text { volume in fuel pin, normalised by average zone } \\
\text { power. }\end{array}$ \\
\hline Regulation bank position & $\mathrm{H}_{\mathrm{reg}}$ & $\mathrm{cm}$ & Distance from core bottom till rods lower edge \\
\hline Control rods worth (in core) & $(\mathrm{RO})_{\mathrm{AP}-1}$ & $\mathrm{pcm}$ & $\begin{array}{l}\text { Effect of control rods insertion in core } \\
\text { supposing the most effective single CR stuck in } \\
\text { upper position. } \\
\text { It is defined as a reactivity difference in two } \\
\text { states: } \\
\text { (RO) AP-1 = RO1-RO2. } \\
\text { The second state differs from the first one only } \\
\text { by additional CRs inserted in core. All the other } \\
\text { parameters correspond to the first state: Cb (that is } \\
\text { equal to Cb crit for the first state), temperature and } \\
\text { FP distribution in core. }\end{array}$ \\
\hline Repeat Criticality Temperature & RCT & ${ }^{\circ} \mathrm{C}$ & $\begin{array}{l}\text { Temperature that ensures a secondary critical state } \\
\text { during core cooling in EOC in such conditions: all } \\
\text { control rods inserted in core except one the most } \\
\text { effective, zero boron concentration, equilibrium xenon } \\
\text { concentration corresponding to reactor power before } \\
\text { its shut-down. }\end{array}$ \\
\hline Moderator temperature coefficient (in core) & MTC & $\mathrm{pcm} /{ }^{\circ} \mathrm{C}$ & \\
\hline Moderator density coefficient (in core) & MDC & $\mathrm{pcm} / \mathrm{g} / \mathrm{cc}$ & \\
\hline Doppler temperature coefficient (in core) & DTC & $\mathrm{pcm} /{ }^{\circ} \mathrm{C}$ & $\begin{array}{l}\text { Calculated supposing average fuel temperature } \\
\text { changing of } 1^{\circ} \mathrm{C}\end{array}$ \\
\hline $\begin{array}{l}\text { Doppler isotermic temperature coefficient } \\
\text { (in core) }\end{array}$ & DTC* & $\mathrm{pcm} /{ }^{\circ} \mathrm{C}$ & $\begin{array}{l}\text { Calculated supposing local fuel temperature } \\
\text { changing of } 1^{\circ} \mathrm{C}\end{array}$ \\
\hline
\end{tabular}


RUSSIAN RESEARCH CENTER KURCHATOV INSTITUTE

Kinetics Parameters of VVER-1000 Core with 3 MOX Lead Test Assemblies to be used for Accident Analysis Codes

\begin{tabular}{|c|c|c|c|}
\hline Doppler power coefficient (in core) & DPC & $\mathrm{pcm} / \mathrm{MW}$ & \\
\hline Boron reactivity coefficient (in core) $^{\mathrm{a}}$ & DRO/DCB & $\mathrm{pcm} / \mathrm{ppm}$ & \\
\hline Effective fraction of delayed neutrons & $\beta$ eff or $\beta_{\text {ef. }}$ & $\mathrm{pcm}$ & General characteristic of infinite grid or core \\
\hline Lifetime of prompt neutrons & $\lambda_{\mathrm{m}}$ or $\lambda_{\mathrm{im}}$ or $l_{\mathrm{im}}$ & $\mathrm{s}$ & General characteristic of infinite grid or core \\
\hline Reactor thermal power & $\mathrm{W}$ & MW & \\
\hline Specific reactor thermal power in CS & Wv & KW/litre & Reactor thermal power in CS volume unit \\
\hline Nominal reactor thermal power & Wnom & MW & Equal to $3000 \mathrm{MW}$ for VVER-1000 \\
\hline $\begin{array}{l}\text { Minimum controllable level of reactor } \\
\text { power }\end{array}$ & MCL & MW & $\begin{array}{l}\text { In calculations corresponds to Zero Power and } \\
\text { uniform temperature } 280^{\circ} \mathrm{C} \text { in core. }\end{array}$ \\
\hline Core coolant flow rate & $\mathrm{G}$ & $\mathrm{m}^{3} / \mathrm{h}$ & \\
\hline Average entry core temperature & $t_{\text {entry }}$ & ${ }^{\circ} \mathrm{C}$ or $\mathrm{K}$ & \\
\hline Average outer core temperature & $\mathrm{t}_{\text {out }}$ & ${ }^{\circ} \mathrm{C}$ or $\mathrm{K}$ & \\
\hline $\begin{array}{l}\text { Average coolant-moderator temperature in } \\
\text { CS }\end{array}$ & $\mathrm{t}_{\mathrm{mod}}$ & ${ }^{\circ} \mathrm{C}$ or $\mathrm{K}$ & \\
\hline $\begin{array}{l}\text { Average Coolant-moderator density in } \\
\text { CS }\end{array}$ & $\gamma_{\text {mod }}$ & $\mathrm{g} / \mathrm{cm}^{3}$ & \\
\hline Fuel temperature & $t_{\text {fuel }}$ & $\mathrm{K}$ & \\
\hline $\begin{array}{l}\text { Average temperature of other } \mathrm{CS} \\
\text { components }\end{array}$ & $\mathrm{t}_{\mathrm{con}}$ & ${ }^{\circ} \mathrm{C}$ or $\mathrm{K}$ & \\
\hline Fuel pin cladding temperature & $\mathrm{t}_{\text {clad }}$ & ${ }^{\circ} \mathrm{C}$ or $\mathrm{K}$ & \\
\hline $\begin{array}{l}\text { Xenon-135 concentration distribution in } \\
\text { core }\end{array}$ & $\mathrm{Xe}$ & $10^{24} / \mathrm{cc}$ & $\begin{array}{l}\text { For } 1 \text { cc in fuel. } \\
\text { In brief description of states the following } \\
\text { notations may be used: } \\
X \mathrm{Xe}=0-\mathrm{xenon} \text { is absent; } \\
\mathrm{Xe}=1-\mathrm{Xe}=\mathrm{Xe} \text { eq }(\mathrm{W}) \text {. }\end{array}$ \\
\hline
\end{tabular}

${ }^{a}$ This coefficient may be calculated either through boron acid concentration (as usual in this report) or through natural boron concentration. In the last case the special indication "(nat B)" is used. The relation is: $\mathrm{DRO} / \mathrm{DCB}$ (nat.B) $=\mathrm{DRO} / \mathrm{DCB} * 5.72$. 
RUSSIAN RESEARCH CENTER KURCHATOV INSTITUTE

Kinetics Parameters of VVER-1000 Core with 3 MOX Lead Test Assemblies to be used for Accident Analysis Codes

\begin{tabular}{|c|c|c|c|}
\hline $\begin{array}{l}\text { Equilibrium Xenon-135 concentration } \\
\text { distribution in core }\end{array}$ & Xe eq $(W)$ & $10^{24} / \mathrm{cc}$ & $\begin{array}{l}\text { Concentration formed during long working with } \\
\mathrm{W} \text { power, regulating bank in nominal position }{ }^{\mathrm{s}}\end{array}$ \\
\hline Sm-149 concentration distribution in core & $\mathrm{Sm}$ & $10^{24} / \mathrm{cc}$ & $\begin{array}{l}\text { For } 1 \text { cc in fuel. } \\
\text { In brief description of states the following } \\
\text { notations may be used: } \\
\qquad \mathrm{Sm}=0-\text { samarium is absent, } \\
\mathrm{Sm}=1-\mathrm{Sm}=\mathrm{Sm} \text { eq, } \\
\mathrm{Sm}=3-\text { in BOC full decay of Pm-149 into } \\
\text { Sm-149 is simulated. }\end{array}$ \\
\hline $\begin{array}{l}\text { Equilibrium Sm-149 concentration } \\
\text { distribution in core }\end{array}$ & Sm eq & $10^{24} / \mathrm{cc}$ & $\begin{array}{l}\text { Concentration formed during long working, } \\
\text { regulating bank in nominal position }\end{array}$ \\
\hline $\begin{array}{l}\text { Samarium-149 concentration distribution, all } \\
\text { Prometium-149 decayed in Sm }\end{array}$ & Smh & $10^{24} / \mathrm{cc}$ & \\
\hline Core reactivity while reactor shut-down & $\mathrm{RO}_{\mathrm{STOP}}$ & $\mathrm{pcm}$ & $\begin{array}{l}\text { Under conditions: } \mathrm{W}=0, \mathrm{Xe}=0, \mathrm{Sm}=\mathrm{Smh} \text {, } \\
\mathrm{t}_{\mathrm{mod}}=\mathrm{t}_{\text {fuel }}=\mathrm{t}_{\mathrm{con}}=20^{\circ} \mathrm{C}, \\
\mathrm{Cb}=16000 \mathrm{ppm}\end{array}$ \\
\hline
\end{tabular}

${ }^{\mathrm{b}}$ In VVER-1000 calculations Hreg in nominal position is equal to $80 \%$ if there is no special indication 


\section{KINETICS PARAMETERS IN REFERENCE URANIUM CORE}

Uranium core with boron BPRs (Fig.1) has been defined in [4] as a reference core for 3 MOX LTAs introduction. The assemblies marked by the same symbol indicate positioning of some assembly during irradiation in the first, second, third and, probably, forth fuel cycle.

The Figures 2-12 and Table 3 show the results of kinetics parameters calculations for the equilibrium fuel cycle in this core.

Fig. 2 and Table 3 show $\beta$ eff evolution during core cycle.

Fig. 3 and 3a, Table13 show core reactivity evolution in the process of control rods simultaneous movement (when AP is actuated) from top to the bottom of core. BOC and EOC moments are considered including the situations when the most effective single control rod is stuck in upper position. Stuck rods location corresponds to Fig.13. In the left column the time while scram actuating is indicated. The whole time of drop is conservatively adopted as equal to $4 \mathrm{~s}$ (in reality its about $2.3 \mathrm{~s}$ ).

It is seen that $(\mathrm{RO})_{\mathrm{AP}-1}$ is $8330 \mathrm{pcm}$ in $\mathrm{BOC}$ and $8570 \mathrm{pcm}$ in EOC in the case of the most effective rod stuck in the core top.

Core reactivity versus regulating group (Fig.13 - bank 10) position is demonstrated in Fig.4 and 4a, Table 14 for BOC and EOC.

Fig.5 and Table 15 show core reactivity evolution while coolant density changing. Density values from $0.2 \mathrm{~g} / \mathrm{cc}$ till $0.766 \mathrm{~g} / \mathrm{cc}$ are considered in zero power states without Xenon. The density of $0.766 \mathrm{~g} / \mathrm{cc}$ corresponds to the state of MCL.

Table 16 shows core reactivity versus core power under the condition that only fuel parameters vary (Doppler effect). For 1-point kinetics model a conventional fuel temperature, indicated also in the Table, can be related to core power levels. Fig. 6 and $6 \mathrm{a}$ give Doppler effect versus this conventional temperature.

Axial power distribution in BOC and EOC is shown in Fig.7 and in Table 17 for several fuel assemblies of different irradiation.

Fig.8 shows assembly average powers, burnup and temperature drop (heatings) ${ }^{\mathrm{a}}$ distributions in BOC and EOC calculated by 3-D code BIPR-7A with 10 levels in axial direction.

Figures 9 and 10 show correspondingly assembly-by-assembly maximum linear pin power distributions in BOC and EOC. The axial levels in Fig.9 and subsequent figures correspond to those in Table 18 (level $4=124.25 \mathrm{~cm}$, level $2=53.25 \mathrm{~cm}$, etc.). Figures 11 and 12 show correspondingly pin-by-pin power distribution in BOC and EOC for the most powered assembly. 2D pin-by-pin calculations by PERMAK-A have been performed for level $4^{\mathrm{b}}$. It is seen from combination of BIPR-7A and PERMAK-A calculations (Figures 9-10 and further 18-19, 27-28, 37-38, 46-47, 56-57, 65-66) that maximum linear pin power in BOC is attained on level 4, in EOC - on level 2.

\footnotetext{
${ }^{a}$ Temperature drop is the difference between output and input coolant temperatures for an assembly considered as a channel.

${ }^{\mathrm{b}}$ Numeration begins from core bottom.
} 


\section{RUSSIAN RESEARCH CENTER KURCHATOV INSTITUTE \\ Kinetics Parameters of VVER-1000 Core with 3 MOX Lead Test Assemblies to be used for Accident Analysis Codes \\ 3. KINETICS PARAMETERS IN URANIUM CORE WITH 3 MOX LTAs}

World experience shows that partially MOX loaded cores (widely used about 30\% MOX loaded core) significantly change the following core neutronics characteristics:

- $(\mathrm{RO})_{\mathrm{AP}-1}$ that is lower in MOX loaded cores (compared with uranium ones);

- $\quad$ Beff that is lower in MOX loaded cores ${ }^{\mathrm{a}}$;

- Doppler coefficient that increases (in absolute values) in MOX loaded cores.

In core loading patterns (Figures 14, 33, 52), chosen in [2], 3 MOX LTAs are placed:

- $\quad$ in the positions without CRs (see Fig.13);

- in core periphery (in two first cycles).

It this case MOX LTAs, even being significantly more absorbent than UOX, influence weakly upon control rods worth (RO) $)_{\mathrm{AP}-1}$. Besides, in case of 3 MOX LTAs in core, $(\mathrm{RO})_{\mathrm{AP}-1}$ depends mainly on core loading pattern and may be both lower and greater than in uranium core.

Two types of MOX LTA has been considered in [1-2]:

- $100 \%$ Plutonium,

- of "Island" type.

Table 12 shows the values of (RO) AP-1 in the case of full CRs insertion (from full power state) for different cycles in uranium reference core and in MOX loaded cores. It is seen that $(\mathrm{RO})_{\mathrm{AP}-1}$ changes weakly while passing from uranium to 3 MOX LTAs loaded cores and no clear tendency is marked. Evolution of reactivity during AP insertion into core is presented in Table 13.

In Tables 4-9 and in Figures 15-17, 24-26, 34-36, 43-45, 53-55, 62-64 the average assembly parameters distributions are presented for 3 cycles with 3 introduced MOX LTAs $100 \%$ Plutonium and of "Island" type. Parameters values evolution is very close in both cases. It is seen from Figures 20-23, 29-32, 39-42, 48-51, 58-61, 67-70 that only pinby-pin distributions are significantly different in $100 \%$ Plutonium and of "Island" type MOX assemblies. So if there is no special indication the presented data for MOX fuelled core concerns the case of $100 \%$ Plutonium MOX LTAs.

It is seen from the Tables 3-9 that $\beta$ eff and DTC evolution during fuel cycles is practically the same in Uranium and MOX loaded cores.

Core reactivity versus regulating group position is demonstrated in Table 14 for BOC and EOC.

Table 15 shows core reactivity evolution while coolant density changing.

Doppler effect (core reactivity versus core power and conventional core fuel temperature) is presented in Table 16 and Figures 6 and 6 a.

Axial power distribution in MOX assemblies for BOC and EOC is shown in Table 18 and Fig.7a.

\footnotetext{
${ }^{\mathrm{a}} \beta$ eff is 0.0064 in U-235 and 0.0021 in Pu-239.
} 


\section{CONSERVATISM ADOPTED FOR TRANSIENT ANALYSIS CALCULATIONS}

The following factors must be taken into account while using of presented neutronics parameters in transient analysis codes:

1.Calculation precision;

2. Uncertainty of reactor design parameters used in neutronics parameters calculation;

3. Possible modification of loading pattern in real conditions that will be different with the calculated case.

In VVER-1000 Uranium core calculations the following precision of neutronics parameters is adopted:

- $\mathrm{RO}-3 \%$

- $\mathrm{qi}-5 \%$;

- $\mathrm{qij}-10 \%$;

- $\mathrm{Kk}-3 \%$;

- $(\mathrm{RO})_{\mathrm{AP}-1}-10 \%$.

Being based particularly on these predictions the limiting values were developed for VVER-1000 Uranium cores to be used in accident analysis on the base of corresponding

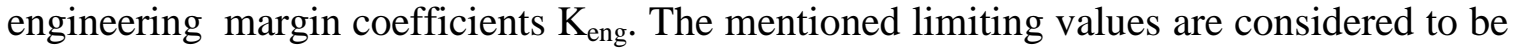
used in 1-point core kinetics model of accident analysis codes particularly in RELAP-like calculations.

The mentioned limiting values actually used in VVER-1000 safety calculations are presented in the second column of Table 2 . The limitations for $\bullet r$ and $\bullet$ o-total are aimed to respect maximum allowable pin linear powers presented in Table 23 including the cases with axial power distributions of cosinus type and of type "maximum in core upper part" (the last is the most dangerous for DNBR). These special axial power distributions are presented in Table 21.

- onservative curves presented in Tables 19-23 are proposed to adopt also for cores with 3 MOX LTAs if the best estimate values for the above-mentioned base Uranium core with boron BPRs and for 3 MOX LTAs cores are found within these limiting values.

In the third and in the forth column the calculated values are presented for the base Uranium core with boron BPRs and for the core with 3 MOX LTAs. As a rule, the parameters values for the 1-th, 2-nd and 3-d fuel cycles of MOX cores are close and in this case they are presented by averaged values. The last column contains the values recommended for VVER-1000 with 3 MOX LTAs. 
In Table 20 the standard "Conservative curve" for VVER-1000 Uranium cores is compared with the calculations of control rods worth from Table 13. The curves for the base Uranium core and MOX cores have been obtained for the minimum $(\mathrm{RO})_{\mathrm{AP}-1}$ values that is for BOC - "Uranium core" and (BOC, MOX-2) - "MOX cores". It is seen that "Conservative curve" gives the slower reactivity evolution during CRs insertion ensuring "conservatism" of accident calculations.

The same conclusion can be applied to Table 19 with "Conservative curve" for Minimum effectiveness of Regulating group.

The curve from the Table 22 leads to more rapid arrival to critical state than the curves cumulated in Table 15 and so can be used as the conservative one.

Table 11 describes the scheme of conservative evaluation of core subcriticality (scram margin) after scram actuation and reactor state transformation from nominal power to MCL. The effects and uncertainties involved in this scheme (vapor effect, absorbent irradiation, uncertainty of CRs worth calculation etc.) correspond to ones adopted in the West, particularly, in the US and France.

In Table 24 delayed neutrons parameters are presented.

In accordance with a type of accident to be calculated in VVER-1000 with 3 MOX LTAs, the corresponding conservative values must be taken from Table 2 (the last column). The details concerning utilisation of these values in different transient calculations is the case of future documents. 
Table 2. Neutronics Data for Transients Analysis

\begin{tabular}{|c|c|c|c|c|}
\hline Parameter & $\begin{array}{l}\text { Values for standard } \\
\text { accident analysis of } \\
\text { VVER-1000 }\end{array}$ & Base Uranium core & $\begin{array}{c}\text { Core with } 3 \text { MOX } \\
\text { LTAs }\end{array}$ & $\begin{array}{c}\text { Recommended values } \\
\text { for accident analysis } \\
\text { of VVER-1000 with } 3 \\
\text { MOX LTAs }\end{array}$ \\
\hline Radial pin power peaking factor $\mathbf{K r}$ & 1.60 & 1.51 (Table 10) & 1.52 (Table 10) & 1.60 \\
\hline Total power peaking factor Ko-total & 2.24 & 1.86 (Table 10) & 1.85 (Table 10$)$ & 2.24 \\
\hline Axial power distribution in assembly & Table 21 & Table17 & Table18 & Table 21 \\
\hline Maximum fuel linear power, W/cm & 448 & 309.5 (Figures 9-10) & $\begin{array}{l}307.8 \\
\text { (Figures 18-19, 27-28, } \\
37-38, \quad 46-47, \quad 56-57, \\
65-66)\end{array}$ & 448 \\
\hline $\begin{array}{l}\text { DTC, } \mathrm{pcm} /{ }^{\circ} \mathrm{C} \\
\text { BOC, MCL } \\
\text { BOC, full power } \\
\text { EOC, MCL } \\
\text { EOC, full power }\end{array}$ & $\begin{array}{l}-2.0 \\
-1.6 \\
-3.0 \\
-2.5\end{array}$ & $\begin{array}{l}-2.13 \\
-2.46 \\
-3.31 \\
-2.80\end{array}$ & $\begin{array}{l}-2.96 \\
-2.47 \\
-3.31 \\
-2.79\end{array}$ & $\begin{array}{l}-2.0 \\
-1.6 \\
-3.0 \\
-2.5\end{array}$ \\
\hline $\begin{array}{l}\text { MTC, pcm } /{ }^{\circ} \mathrm{C} \\
\text { BOC, MCL } \\
\text { BOC, full power } \\
\text { EOC, MCL } \\
\text { EOC, full power }\end{array}$ & $\begin{array}{l}0 \\
-10 \\
-65 \\
-60\end{array}$ & $\begin{array}{l}-1.23 \\
-25.94 \\
-27.52 \\
-60.05\end{array}$ & $\begin{array}{l}-0.94 \\
-24.63 \\
-27.59 \\
-59.82\end{array}$ & $\begin{array}{l}0 \\
-10 \\
-65 \\
-60\end{array}$ \\
\hline MDC, $\mathrm{pcm} / \mathrm{g} / \mathrm{cc}$ & $0-34000$ & $12293-28260$ & $11833-28338$ & $0-34000$ \\
\hline $\begin{array}{lll}\begin{array}{l}\text { Core reactivity } \\
\text { density }\end{array} & \text { versus } & \text { coolant } \\
\end{array}$ & Table 22 & Table 15 & Table 15 & Table 22 \\
\hline Boron reactivity coefficient & From - 6 & From -8.87 & From -8.87 & From - 6 \\
\hline
\end{tabular}


RUSSIAN RESEARCH CENTER KURCHATOV INSTITUTE

Kinetics Parameters of VVER-1000 Core with 3 MOX Lead Test Assemblies to be used for Accident Analysis Codes

\begin{tabular}{|c|c|c|c|c|}
\hline DRO/DCB (nat. B), pcm/ppm & till $\quad-12$ & -9.84 & Till -8.90 & -12 \\
\hline $\begin{array}{l}\text { Regulation group effectiveness, pcm } \\
\text { Minimum } \\
\text { Maximum }\end{array}$ & $\begin{array}{l}620 \\
1000\end{array}$ & $\begin{array}{l}910 \\
940\end{array}$ & $\begin{array}{l}750 \\
950\end{array}$ & $\begin{array}{c}620 \\
1000\end{array}$ \\
\hline $\begin{array}{l}\text { Minimum } \begin{array}{l}\text { effectiveness } \\
\text { Regulation } \\
\text { depth }\end{array} \\
\text { group versus insertion } \\
\end{array}$ & $\begin{array}{l}\text { Conservative curve } \\
\text { from Table } 19\end{array}$ & Table 19 & Table 19 & $\begin{array}{l}\text { Conservative } \\
\text { from Table } 19\end{array}$ \\
\hline $\begin{array}{l}\text { Control rods worth }(\mathbf{R O})_{\mathrm{AP}-\mathbf{1}} \text {, } \\
\text { Minimum over cycle, pcm } \\
\text { Full power }\end{array}$ & 5500 & 8330 & 8180 & 5500 \\
\hline $\begin{array}{l}\text { Relative Core reactivity evolution in } \\
\text { the process of control rods } \\
\text { movement }\end{array}$ & $\begin{array}{ll}\text { Conservative } & \text { core } \\
\text { from Table } 20 & \end{array}$ & Table 20 & Table 20 & $\begin{array}{l}\text { Conservative core from } \\
\text { Table } 20\end{array}$ \\
\hline $\begin{array}{lll}\text { Repeat } & \text { Criticality } & \text { Temperature } \\
\text { RCT, } & & \\
{ }^{\circ} \mathrm{C} & & \\
\end{array}$ & 210 & 124 & $\begin{array}{l}129 \text { (1-st Cycle) } \\
130 \text { (2-nd Cycle) } \\
117 \text { (3-d Cycle) }\end{array}$ & 210 \\
\hline $\begin{array}{l}\text { Beff, pcm } \\
\text { BOC } \\
\text { EOC }\end{array}$ & $\begin{array}{l}600 \\
520\end{array}$ & $\begin{array}{l}650 \\
551\end{array}$ & $\begin{array}{l}648 \\
548\end{array}$ & $\begin{array}{l}600 \\
520\end{array}$ \\
\hline $\begin{array}{l}\text { Lifetime of Prompt neutrons, micro- } \\
\text { s } \\
\text { BOC } \\
\text { EOC }\end{array}$ & $\begin{array}{l}22.0 \\
25.3\end{array}$ & $\begin{array}{l}22.4 \\
25.5\end{array}$ & $\begin{array}{l}22.3 \\
25.7\end{array}$ & $\begin{array}{l}22.0 \\
25.3\end{array}$ \\
\hline
\end{tabular}




\section{CONCLUSION}

The report is aimed to obtain data necessary for transient analysis codes while safety studying of VVER-1000 core with 3 MOX LTAs.

The set of kinetics parameters is presented both for Uranium reference core and for 3 MOX LTAs loaded cores. On this base the conservative values of neutronics parameters to be used in transient calculations are proposed.

Details about applying the presented information to different types of accidents is the case of future documents. 


\section{References}

1. S.A.Bychkov, A.A. Lazarenko, Y.A. Styrin, V.D.Sidorenko. Results of Parametric Design Studies of MOX Lead Test Assembly (Final Report for FY98).

Moscow, Kurchatov Institute 1998.

2. Y.A. Styrin. Calculations of MOX LTA Performance in VVER-1000 Core.

Moscow, Kurchatov Institute 1998.

3. RELAP5/MOD3 CODE MANUAL VOLUME I: CODE STRUCTURE, SYSTEM MODELS AND SOLUTION METHODS

NUREG/CR-5535, INEL-95/0174

4. Y.A. Styrin, I.K.Levina. Design of Lead Test MOX Assemblies for Pilot Irradiation in VVER-1000 and Related Parametric Studies. Draft.

Moscow, Kurchatov Institute 1998.

5. In-core fuel management code package validation for WWERs. IAEA-TECDOC-847. November 1995.

6. A.A.Gorokhov, Y.A. Styrin. Generation of Preliminary Kinetics Parameters for Accident Analysis Codes.

Moscow, Kurchatov Institute 1998. 
RUSSIAN RESEARCH CENTER KURCHATOV INSTITUTE

Kinetics Parameters of VVER-1000 Core with 3 MOX Lead Test Assemblies to be used for Accident Analysis Codes

Table 3. Evolution of main neutronics parameters in Uranium reference core . Equilibrium cycle

$\mathrm{Sim}=60, \mathrm{Xe}=1, \mathrm{Sm}=3$

\begin{tabular}{|c|c|c|c|c|c|c|c|c|c|c|c|c|c|c|c|c|c|c|c|c|c|c|c|}
\hline$N$ & $\begin{array}{c}\text { T } \\
\text { EFPD }\end{array}$ & $\begin{array}{c}\mathrm{H}_{\text {reg. }} \\
\mathrm{cm}\end{array}$ & $\begin{array}{l}t_{\text {entry }} \\
{ }^{\circ} \mathrm{C}\end{array}$ & $\begin{array}{c}\text { W } \\
\text { MW }\end{array}$ & $\begin{array}{c}\mathrm{Cb}^{\text {crit. }} \\
\text { ppm }\end{array}$ & $\begin{array}{c}\mathbf{G} \\
\mathrm{m}^{3} / \mathrm{h}\end{array}$ & $\mathrm{Kq}$ & Nk & $\mathrm{Kq}^{\text {MOX }}$ & Nk & $\mathrm{Kv}$ & Nk & $\mathrm{Nz}$ & $\begin{array}{c}\bar{B}_{\mathbf{U}} \\
\mathrm{MW} \bullet \\
\mathrm{d} / \mathrm{kg}\end{array}$ & $\begin{array}{c}\overline{\mathbf{B}}_{\mathbf{y o x}} \\
\text { MW• } \\
\mathrm{d} / \mathrm{kg}\end{array}$ & $\begin{array}{c}\mathrm{MDC} \\
\mathrm{pcm} \cdot \\
\left(\mathrm{g} / \mathrm{cm}^{3}\right)^{-1}\end{array}$ & $\begin{array}{c}\text { MTC } \\
\text { pcm• } \\
{ }^{\circ} \mathrm{C}^{-1}\end{array}$ & $\begin{array}{l}\text { DTC } \\
\text { pcm• } \\
{ }^{\circ} \mathrm{C}^{-1}\end{array}$ & $\begin{array}{l}\mathrm{DTC}^{*} \\
\text { pcm• } \\
{ }^{\circ} \mathrm{C}^{-1}\end{array}$ & $\begin{array}{l}\text { DPC } \\
\mathrm{pcm}^{\bullet} \\
\mathrm{MW}^{-1}\end{array}$ & $\begin{array}{c}\text { DRo/DCb } \\
\text { pcm• } \\
\mathrm{ppm}^{-1}\end{array}$ & $\begin{array}{c}\boldsymbol{\beta}_{\text {ef. }} \\
\text { pcm }\end{array}$ & $\begin{array}{r}\mathrm{l}_{\mathrm{im}} \\
\cdot 10^{5} \\
\mathrm{sec}\end{array}$ \\
\hline 1 & 0.0 & 33.2 & 87.0 & 3000 & 5657 & 84000 & 131 & 19 & 0.00 & 0 & 61 & 19 & 4 & 14.14 & 0.00 & 12293 & 2501 & 206 & -246 & -0.29 & -1.55 & 650 & 2.24 \\
\hline 2 & 20.0 & 283.2 & 287.0 & 3000 & 5318 & 84000 & 1.31 & 19 & 0.00 & 0 & .58 & 19 & 4 & & 0.00 & & -26 & & & & & 639 & 2.24 \\
\hline 3 & 40.0 & 283.2 & 287.0 & 3000 & 4899 & 84000 & 1.31 & 19 & 0.00 & 0 & 1.56 & 19 & 4 & 15.85 & 0.00 & 14000 & -29.20 & -2.94 & -2.48 & & & 630 & 2.25 \\
\hline 4 & 60.0 & 283.2 & 287.0 & 3000 & 4473 & 84000 & 1.31 & 19 & 0.00 & 0 & 1.5 & 19 & 3 & 16.70 & 0.00 & & -31.6 & -2.93 & -2.5 & & & 622 & 2.27 \\
\hline 5 & 80.0 & 283.2 & 287.0 & 3000 & 4047 & 84000 & 1.31 & 19 & 0.00 & 0 & 1.52 & 19 & 3 & 17.55 & 0.00 & 16400 & -34.24 & -2.93 & -2.52 & -0.29 & & 613 & 2.29 \\
\hline 6 & 100.0 & 283.2 & 287.0 & 3000 & 3631 & 84000 & 1.31 & 19 & 0.00 & 0 & 1.51 & 19 & 3 & 18.41 & 0.00 & 17590 & -36.77 & -2.94 & -2.55 & & & 606 & 2.31 \\
\hline 7 & 120.0 & 283.2 & 287.0 & 3000 & 3215 & 84000 & 1.30 & 19 & 0.00 & 0 & 1.50 & 19 & 3 & 19.26 & 0.00 & 18775 & -39.30 & -2.96 & -2.58 & & & 598 & 2.33 \\
\hline 8 & 140.0 & 283.2 & 287.0 & 3000 & 2813 & 84000 & 1.30 & 19 & 0.00 & 0 & 1.49 & 19 & 3 & 20.11 & 0.00 & & -41.77 & -2.97 & -2.60 & & & 591 & 2.35 \\
\hline 9 & 160.0 & 283.2 & 287.0 & 3000 & 2411 & 84000 & 1.30 & 19 & 0.00 & 0 & 1.48 & 19 & 3 & 20.96 & 0.00 & & -44.25 & -2.99 & -2.63 & & & 585 & 2.37 \\
\hline 10 & 180.0 & 283.2 & 287.0 & 3000 & 2023 & 84000 & 1.30 & 19 & 0.00 & 0 & 1.47 & 19 & 2 & 21.82 & 0.00 & 22203 & -46.69 & -3.02 & -2.66 & -0.29 & -1.64 & 578 & 2.40 \\
\hline 11 & 200.0 & & 287.0 & 3000 & 1634 & & & 19 & 0.00 & 0 & & 19 & 2 & 22.67 & 0.00 & & -49.16 & -3.04 & -2.69 & & & 573 & 2.42 \\
\hline 12 & 220.0 & 283.2 & 287.0 & 3000 & 1254 & 84000 & 1.29 & 19 & 0.00 & 0 & 1.47 & 19 & 2 & 23.52 & 0.00 & & -51.62 & -3.06 & -2.71 & & & 567 & 2.45 \\
\hline 13 & 240.0 & 283.2 & 287.0 & 3000 & 874 & 84000 & 1.29 & 19 & 0.00 & 0 & 1.47 & 19 & 2 & 24.37 & 0.00 & & -54.13 & -3.08 & -2.74 & & & 562 & 2.48 \\
\hline 14 & 260.0 & 283.2 & 287.0 & 3000 & 500 & 84000 & 1.29 & 19 & 0.00 & 0 & & 19 & 2 & 25.23 & 0.00 & & -56.64 & -3.09 & -2.76 & & & 557 & 2.51 \\
\hline 15 & 280.0 & 283.2 & 287.0 & 3000 & 127 & 84000 & 1.28 & 19 & 0.00 & 0 & 1.46 & 19 & 2 & 26.08 & 0.00 & 27869 & -59.18 & -3.11 & -2.79 & -0.30 & -1.71 & 552 & 2.54 \\
\hline 16 & 286.9 & 283.2 & 287.0 & 3000 & 0 & 84000 & 1.28 & 19 & 0.00 & 0 & 1.45 & 19 & 2 & 26.37 & 0.00 & 28260 & -60.05 & -3.12 & -2.80 & -0.30 & -1.72 & 551 & 2.55 \\
\hline
\end{tabular}


RUSSIAN RESEARCH CENTER KURCHATOV INSTITUTE

Kinetics Parameters of VVER-1000 Core with 3 MOX Lead Test Assemblies to be used for Accident Analysis Codes

Table 4. Evolution of main neutronics parameters. First cycle with 3 MOX LTAs $100 \% \mathrm{Pu}(4.2-3.0-2.0)$

$\mathrm{Sim}=360, \mathrm{Xe}=1, \mathrm{Sm}=3$

\begin{tabular}{|c|c|c|c|c|c|c|c|c|c|c|c|c|c|c|c|c|c|c|c|c|c|c|c|}
\hline$N^{n}$ & $\begin{array}{c}\mathbf{T} \\
\text { EFPD }\end{array}$ & $\begin{array}{l}\mathrm{H}_{\text {reg. }} \\
\mathrm{cm}\end{array}$ & $\begin{array}{c}t_{\text {entry }} \\
{ }^{\circ} \mathrm{C}\end{array}$ & $\begin{array}{c}\text { W } \\
\text { MW }\end{array}$ & $\begin{array}{l}\mathrm{Cb}^{\text {crit. }} \\
\mathrm{ppm}\end{array}$ & $\begin{array}{c}\mathbf{G} \\
\mathrm{m}^{3} / \mathrm{h}\end{array}$ & $\mathrm{Kq}$ & Nk & $\mathrm{Kq}^{\mathrm{xOx}}$ & Nk & Kv & Nk & $\mathrm{Nz}$ & $\begin{array}{c}\overline{\mathrm{B}}_{\mathrm{U}} \\
\mathrm{MW} \bullet \\
\mathrm{d} / \mathrm{kg}\end{array}$ & $\begin{array}{l}\bar{B}_{\text {Mox }} \\
\text { MW• } \\
d / k g\end{array}$ & $\begin{array}{c}\text { MDC } \\
\text { pcm• } \\
\left(\mathrm{g} / \mathrm{cm}^{3}\right)^{-1}\end{array}$ & $\begin{array}{l}\text { MTC } \\
\text { pcm॰ } \\
{ }^{\circ} \mathrm{C}^{-1}\end{array}$ & $\begin{array}{l}\text { DTC } \\
\text { pcm• } \\
{ }^{\circ} \mathrm{C}^{-1}\end{array}$ & $\begin{array}{l}\mathrm{DTC}^{*} \\
\text { pcm• } \\
{ }^{\circ} \mathrm{C}^{-1}\end{array}$ & $\begin{array}{l}\text { DPC } \\
\text { pcm• } \\
\mathrm{MW}^{-1}\end{array}$ & $\begin{array}{c}\text { DRo/DCb } \\
\text { pcm• }^{-1} \\
\text { ppm }^{-1}\end{array}$ & $\begin{array}{l}\boldsymbol{\beta}_{\text {ef. }} \\
\text { pcm }\end{array}$ & $\begin{array}{r}\mathrm{l}_{\mathrm{im}} \\
\cdot 10^{5} \\
\mathrm{sec}\end{array}$ \\
\hline 1 & 0.0 & 283.2 & 287.0 & 3000 & 5784 & 84000 & 1.32 & 38 & 1.03 & 8 & 1.61 & 38 & 4 & 14.26 & 0.00 & 12029 & -25.00 & -2.88 & -2.49 & -0.28 & -1.55 & 642 & 2.23 \\
\hline 2 & 20.0 & 283.2 & 287.0 & 3000 & 5439 & 84000 & 1.27 & 38 & 0.98 & 8 & 1.52 & 38 & 4 & 15.12 & 0.88 & 12614 & -25.94 & -2.89 & -2.51 & -0.28 & -1.56 & 632 & 2.24 \\
\hline 3 & 40.0 & 283.2 & 287.0 & 3000 & 5012 & 84000 & 1.27 & 38 & 0.95 & 8 & 1.49 & 11 & 4 & 15.97 & 1.71 & 13743 & -28.28 & -2.88 & -2.52 & -0.28 & -1.57 & 624 & 2.26 \\
\hline 4 & 60.0 & 283.2 & 287.0 & 3000 & 4585 & 84000 & 1.26 & 117 & 0.93 & 8 & $1.4^{7}$ & 117 & 3 & 16.82 & 2.52 & 14944 & -30.82 & -2.88 & -2.54 & -0.28 & -1.58 & 616 & 2.27 \\
\hline 5 & 80.0 & 283.2 & 287.0 & 3000 & 4152 & 84000 & 1.26 & 92 & 0.92 & 150 & 1.45 & 92 & 3 & 17.68 & 3.32 & 16173 & -33.43 & -2.89 & -2.56 & -0.28 & -1.59 & 608 & 2.29 \\
\hline 6 & 100.0 & 283.2 & 287.0 & 3000 & 3725 & 84000 & 1.26 & 92 & 0.91 & 150 & 1.45 & 92 & 3 & 18.53 & 4.10 & 17390 & -36.04 & -2.90 & -2.58 & -0.28 & -1.60 & 601 & 2.31 \\
\hline 7 & 120.0 & 283.2 & 287.0 & 3000 & 3298 & 84000 & 1.27 & 92 & 0.91 & 88 & 1.45 & 92 & 3 & 19.38 & 4.88 & 18604 & -38.65 & -2.91 & -2.61 & -0.28 & -1.61 & 594 & 2.33 \\
\hline 8 & 140.0 & 283.2 & 287.0 & 3000 & 2887 & 84000 & 1.27 & 92 & 0.90 & 88 & 1.44 & 92 & 3 & 20.24 & 5.66 & 19785 & -41.20 & -2.93 & -2.63 & -0.28 & -1.62 & 587 & 2.35 \\
\hline 9 & 160.0 & 283.2 & 287.0 & 3000 & 2476 & 84000 & 1.27 & 92 & 0.90 & 88 & 1.44 & 124 & 3 & 21.09 & 6.42 & 20964 & -43.75 & -2.95 & -2.65 & -0.29 & -1.64 & 581 & 2.38 \\
\hline 10 & 180.0 & 283.2 & 287.0 & 3000 & 2072 & 84000 & 1.27 & 92 & 0.89 & 88 & 1.44 & 124 & 2 & 21.95 & 7.19 & 22131 & -46.29 & -2.97 & -2.68 & -0.29 & -1.65 & 575 & 2.40 \\
\hline 11 & 200.0 & 283.2 & 287.0 & 3000 & 1669 & 84000 & 1.27 & 124 & 0.89 & 88 & 1.45 & 124 & 2 & 22.80 & 7.95 & 23302 & -48.86 & -2.99 & -2.70 & -0.29 & -1.66 & 569 & 2.43 \\
\hline 12 & 220.0 & 283.2 & 287.0 & 3000 & 1276 & 84000 & 1.27 & 124 & 0.88 & 88 & 1.45 & 124 & 2 & 23.65 & 8.70 & 24460 & -51.40 & -3.01 & -2.72 & -0.29 & -1.68 & 564 & 2.46 \\
\hline 13 & 240.0 & 283.2 & 287.0 & 3000 & 883 & 84000 & 1.28 & 124 & 0.88 & 88 & 1.46 & 124 & 2 & 24.51 & 9.46 & 25627 & -53.97 & -3.03 & -2.75 & -0.29 & -1.69 & 559 & 2.49 \\
\hline 14 & 260.0 & 283.2 & 287.0 & 3000 & 491 & 84000 & 1.28 & 124 & 0.88 & 88 & 1.46 & 124 & 2 & 25.36 & 10.21 & 26802 & -56.58 & -3.04 & -2.77 & -0.29 & -1.71 & 554 & 2.52 \\
\hline 16 & 285.8 & 283.2 & 287.0 & 3000 & 0 & 84000 & 1.27 & 124 & 0.88 & 88 & 1.45 & 124 & 2 & 26.47 & 11.18 & 28297 & -59.90 & -3.07 & -2.79 & -0.29 & -1.73 & 548 & 2.56 \\
\hline
\end{tabular}


RUSSIAN RESEARCH CENTER KURCHATOV INSTITUTE

Kinetics Parameters of VVER-1000 Core with 3 MOX Lead Test Assemblies to be used for Accident Analysis Codes

Table 5. Evolution of main neutronics parameters. First cycle with 3 MOX LTAs of "Island" type: $\{\mathrm{Pu}(3.8-2.8)-$ U3.7\%\}

$\mathrm{Sim}=360, \mathrm{Xe}=1, \mathrm{Sm}=3$

\begin{tabular}{|c|c|c|c|c|c|c|c|c|c|c|c|c|c|c|c|c|c|c|c|c|c|c|c|}
\hline$N$ & $\begin{array}{c}\mathbf{T} \\
\text { EFPD }\end{array}$ & $\begin{array}{c}\mathrm{H}_{\text {reg. }} \\
\mathrm{cm}\end{array}$ & $\begin{array}{c}t_{\text {entry }} \\
{ }^{\circ} \mathrm{C}\end{array}$ & $\begin{array}{c}\text { W } \\
\text { MW }\end{array}$ & $\begin{array}{l}\mathrm{Cb}^{\text {crit. }} \\
\text { ppm }\end{array}$ & $\begin{array}{c}\mathbf{G} \\
\mathrm{m}^{3} / \mathrm{h}\end{array}$ & $\mathrm{Kq}$ & Nk & $\mathrm{Kq}^{\mathrm{MOX}}$ & Nk & $\mathrm{Kv}$ & Nk & $\mathrm{Nz}$ & $\begin{array}{c}\overline{\mathrm{B}}_{\mathrm{U}} \\
\mathrm{MW} \bullet \\
\mathrm{d} / \mathrm{kg}\end{array}$ & $\begin{array}{c}\overline{\mathrm{B}}_{\text {yox }} \\
\mathrm{MW} \bullet \\
\mathrm{d} / \mathrm{kg}\end{array}$ & $\begin{array}{c}\text { MDC } \\
\text { pcm• } \\
\left(\mathrm{g} / \mathrm{cm}^{3}\right)^{-1}\end{array}$ & $\begin{array}{l}\text { MTC } \\
\text { pcm• } \\
{ }^{\circ} \mathrm{C}^{-1}\end{array}$ & $\begin{array}{l}\text { DTC } \\
\text { pcm } \\
{ }^{\circ} \mathrm{C}^{-1}\end{array}$ & $\begin{array}{l}\text { DTC } \\
\text { pcm• } \\
{ }^{\circ} \mathrm{C}^{-1}\end{array}$ & $\begin{array}{l}\text { DPC } \\
\text { pcm• } \\
\mathrm{MW}^{-1}\end{array}$ & $\begin{array}{c}\text { DRo/DCb } \\
\mathrm{pcm}^{-} \\
\mathrm{ppm}^{-1}\end{array}$ & $\begin{array}{l}\beta_{\text {ef. }} \\
\text { pcm }\end{array}$ & $\begin{array}{r}\mathrm{l}_{\mathrm{im}} \\
\cdot 10^{5} \\
\mathrm{sec}\end{array}$ \\
\hline 1 & 0.0 & 283.2 & 287.0 & 3000 & 5773 & 84000 & 1.32 & 38 & 1.01 & 8 & 161 & 38 & 4 & 14.26 & 0.00 & & -24.84 & -2.88 & -2.49 & -0.28 & -1.57 & 647 & 2.25 \\
\hline 2 & 20.0 & 283.2 & 287.0 & 3000 & 5435 & 84000 & 1.27 & 38 & 97 & 8 & 52 & 8 & 4 & 15.12 & 0.86 & & -25 & & -2 . & -0.28 & & & 2.25 \\
\hline 3 & & 283.2 & 287.0 & 3000 & 5014 & 000 & 1.26 & 38 & 0.97 & $\varepsilon$ & .49 & 8 & & 5.97 & 1.69 & & -28 & 2 & -2 & & & & .27 \\
\hline 4 & 0.0 & 283.2 & 287.0 & 3000 & 4586 & 84000 & 1.26 & 117 & 0.97 & 8 & 1.47 & 47 & 3 & 16.82 & 2.52 & & -30 & -2 & -2.5 & -0.28 & & 20 & 2.28 \\
\hline 5 & 80.0 & 283.2 & 287.0 & 3000 & 4158 & 84000 & 1.26 & 72 & 0.96 & 150 & 1.45 & 72 & 3 & 17.67 & 3.34 & 16104 & -33. & -2.88 & -2.55 & -0.28 & -1.60 & 612 & 2.30 \\
\hline 6 & 100.0 & 283.2 & 287.0 & 3000 & 3737 & 000 & 1.26 & 72 & 0.96 & 150 & 1.44 & 132 & 3 & 18.53 & 4.16 & & -35.88 & -2.89 & -2.58 & -028 & & 304 & 2.32 \\
\hline 7 & 120.0 & 283.2 & 287.0 & 3000 & 3316 & 84000 & 1.26 & 132 & 0.96 & 88 & 1.44 & 132 & 3 & 19.38 & 4.98 & & -38 & -2 . & -2.60 & -0.28 & & 97 & 2.34 \\
\hline 8 & 140.0 & 283.2 & 287.0 & 3000 & 2905 & 84000 & 1.26 & 132 & 0.96 & 88 & 1.44 & 132 & 3 & 20.23 & 5.80 & & -41.02 & -2.92 & -2.62 & -0.28 & & 90 & 2.36 \\
\hline 9 & 160.0 & 283.2 & 287.0 & 3000 & 2493 & 84000 & 1.26 & 132 & 0.96 & 8 & 1.43 & 124 & 3 & 21.09 & 6.62 & & -43 & -2.94 & -2.65 & -0.28 & & 84 & 2.39 \\
\hline 10 & 180.0 & 283.2 & 287.0 & 3000 & 2093 & 84000 & 1.27 & 132 & 0.96 & 88 & 1.44 & 124 & 2 & 21.94 & 7.44 & 22050 & -46.11 & -2.96 & -2.67 & -0.29 & -1.66 & 578 & 2.41 \\
\hline 11 & 200.0 & 283.2 & 287.0 & 3000 & 1694 & & 1.27 & 124 & 0.96 & 8 & 1.44 & 124 & 2 & 22.79 & 8.25 & & -48.66 & -2.98 & -2.7 & -0.29 & & 72 & 2.44 \\
\hline 12 & 220.0 & 283.2 & 287.0 & 3000 & 1301 & 84000 & 1.27 & 124 & 0.96 & 88 & 1.45 & 124 & 2 & 23.65 & 9.07 & & -51 & -3.0 & -2.72 & -0.29 & & 566 & 2.47 \\
\hline 13 & 240.0 & 283.2 & 287.0 & 3000 & 909 & 84000 & 1.27 & 124 & 0.96 & 88 & 1.45 & 124 & 2 & 24.50 & 9.88 & & -53.76 & -3.02 & -2.74 & -0.29 & & 561 & 2.49 \\
\hline 14 & 260.0 & 283.2 & 287.0 & 3000 & 524 & 84000 & 1.27 & 124 & 0.96 & 88 & 1.45 & 124 & 2 & 25.35 & 10.70 & & -56 & -3.04 & -2.76 & -0.29 & & 556 & 2.52 \\
\hline 15 & 280.0 & 283.2 & 287.0 & 3000 & 139 & 84000 & 1.27 & 124 & 0.96 & 88 & 1.45 & 124 & 2 & 26.21 & 11.51 & 27861 & -58.91 & -3.05 & -2.79 & -0.29 & -1.73 & 552 & 2.55 \\
\hline 16 & 287.4 & 283.2 & 287.0 & 3000 & 0 & 84000 & 1.27 & 124 & 0.96 & 88 & 1.45 & 124 & 2 & 26.52 & 11.81 & 28287 & -59.87 & -3.06 & -2.79 & -0.29 & -1.73 & 550 & 2.57 \\
\hline
\end{tabular}


RUSSIAN RESEARCH CENTER KURCHATOV INSTITUTE

Kinetics Parameters of VVER-1000 Core with 3 MOX Lead Test Assemblies to be used for Accident Analysis Codes

Table 6. Evolution of main neutronics parameters. 2-nd cycle with 3 MOX LTAs 100\%Pu(4.2-3.0-2.0)

$\mathrm{Sim}=360, \mathrm{Xe}=1, \mathrm{Sm}=3$

\begin{tabular}{|c|c|c|c|c|c|c|c|c|c|c|c|c|c|c|c|c|c|c|c|c|c|c|c|}
\hline$N^{n}$ & $\begin{array}{c}\mathrm{T} \\
\text { EFPD }\end{array}$ & $\begin{array}{c}\mathrm{H}_{\text {reg. }} \\
\mathrm{cm}\end{array}$ & $\begin{array}{c}t_{\text {entry }} \\
{ }^{\circ} \mathrm{C}\end{array}$ & $\begin{array}{c}\text { W } \\
\text { MW }\end{array}$ & $\begin{array}{l}\mathrm{Cb}^{\text {crit. }} \\
\text { ppm }\end{array}$ & $\begin{array}{c}\mathbf{G} \\
\mathrm{m}^{3} / \mathrm{h}\end{array}$ & $\mathrm{Kq}$ & Nk & $\mathrm{Kq}^{\mathrm{MOX}}$ & Nk & Kv & Nk & $\mathrm{Nz}$ & $\begin{array}{c}\overline{\mathrm{B}}_{\mathrm{U}} \\
\mathrm{MW} \bullet \\
\mathrm{d} / \mathrm{kg}\end{array}$ & $\begin{array}{c}\bar{B}_{\text {MOX }} \\
\text { MW• } \\
\text { d/kg }\end{array}$ & $\begin{array}{c}\text { MDC } \\
\text { pcm• } \\
\left(\mathrm{g} / \mathrm{cm}^{3}\right)^{-1}\end{array}$ & $\begin{array}{l}\text { MTC } \\
\text { pcm• } \\
{ }^{\circ} \mathrm{C}^{-1}\end{array}$ & $\begin{array}{c}\text { DTC } \\
\text { pcm• } \\
{ }^{\circ} \mathrm{C}^{-1}\end{array}$ & $\begin{array}{l}\text { DTC }^{*} \\
\text { pcm• } \\
{ }^{\circ} \mathrm{C}^{-1}\end{array}$ & $\begin{array}{c}\text { DPC } \\
\text { pcm• } \\
\mathrm{MW}^{-1}\end{array}$ & $\begin{array}{c}\text { DRo/DCb } \\
\mathrm{pcm}^{-} \\
\mathrm{ppm}^{-1}\end{array}$ & $\begin{array}{l}\boldsymbol{\beta}_{\text {ef. }} \\
\mathrm{pcm}\end{array}$ & $\begin{array}{l}\mathrm{l}_{\mathrm{im}} \\
\cdot 10^{5} \\
\mathrm{sec}\end{array}$ \\
\hline 1 & 0.0 & 283.2 & 287.0 & 3000 & 5666 & 84000 & 1.34 & 153 & 1.21 & 141 & 1.66 & 153 & 4 & 13.82 & 11.18 & 12450 & -26.03 & -2.89 & -2.49 & -0.28 & -1.55 & 642 & 2.23 \\
\hline 2 & 20.0 & 283.2 & 287.0 & 3000 & 5325 & 84000 & 1.28 & 153 & 1.20 & 141 & 1.56 & 153 & 4 & 14.67 & 12.21 & 13070 & -27.06 & -2.89 & -2.50 & -0.28 & -1.55 & 632 & 2.24 \\
\hline 3 & 40.0 & 283.2 & 287.0 & 3000 & 4904 & 84000 & 1.28 & 153 & 1.18 & 141 & 1.53 & 153 & 4 & 15.52 & 13.23 & 14186 & -29.37 & -2.88 & -2.52 & -0.28 & -1.56 & 624 & 2.25 \\
\hline 4 & 60.0 & 283.2 & 287.0 & 3000 & 4484 & 84000 & 1.28 & 153 & 1.17 & 141 & 1.50 & 153 & 3 & 16.37 & 14.23 & 15365 & -31.85 & -2.88 & -2.53 & -0.28 & -1.57 & 616 & 2.27 \\
\hline 5 & 80.0 & 283.2 & 287.0 & 3000 & 4055 & 84000 & 1.27 & 153 & 1.16 & 141 & 1.47 & 153 & 3 & 17.22 & 15.23 & 16573 & -34.41 & -2.88 & -2.56 & -0.28 & -1.58 & 608 & 2.28 \\
\hline 7 & 120.0 & 283.2 & 287.0 & 3000 & 3212 & 84000 & 1.25 & 153 & 1.15 & 18 & 1.43 & 47 & 3 & 18.92 & 17.21 & 18964 & -39.52 & -2.90 & -2.60 & -0.28 & -1.61 & 594 & 2.33 \\
\hline 8 & 140.0 & 283.2 & 287.0 & 3000 & 2805 & 84000 & 1.25 & 110 & 1.14 & 18 & 1.41 & 47 & 3 & 19.77 & 18.19 & 20126 & -42.02 & -2.92 & -2.62 & -0.28 & -1.62 & 587 & 2.35 \\
\hline 9 & 160.0 & 283.2 & 287.0 & 3000 & 2398 & 84000 & 1.25 & 110 & 1.14 & 18 & 1.41 & 110 & 3 & 20.62 & 19.16 & 21284 & -44.52 & -2.93 & -2.65 & -0.28 & -1.63 & 581 & 2.37 \\
\hline 10 & 180.0 & 283.2 & 287.0 & 3000 & 2000 & 84000 & 1.25 & 110 & 1.13 & 18 & 1.41 & 110 & 2 & 21.47 & 20.13 & 22429 & -47.00 & -2.95 & -2.67 & -0.29 & -1.65 & 575 & 2.40 \\
\hline 11 & 200.0 & 283.2 & 287.0 & 3000 & 1602 & 84000 & 1.25 & 110 & 1.12 & 18 & 1.42 & 110 & 2 & 22.32 & 21.09 & 23578 & -49.50 & -2.97 & -2.69 & -0.29 & -1.66 & 569 & 2.42 \\
\hline 12 & 220.0 & 283.2 & 287.0 & 3000 & 1215 & 84000 & 1.26 & 110 & 1.12 & 18 & 1.42 & 110 & 2 & 23.17 & 22.05 & 24712 & -51.98 & -2.99 & -2.72 & -0.29 & -1.67 & 564 & 2.45 \\
\hline 13 & 240.0 & 283.2 & 287.0 & 3000 & 827 & 84000 & 1.26 & 110 & 1.12 & 18 & 1.43 & 110 & 2 & 24.02 & 23.00 & 25855 & -54.49 & -3.01 & -2.74 & -0.29 & -1.69 & 559 & 2.48 \\
\hline 14 & 260.0 & 283.2 & 287.0 & 3000 & 446 & 84000 & 1.26 & 110 & 1.11 & 18 & 1.43 & 110 & 2 & 24.87 & 23.96 & 26995 & -57.00 & -3.03 & -2.76 & -0.29 & -1.70 & 554 & 2.51 \\
\hline 16 & 283.5 & 283.2 & 287.0 & 3000 & 0 & 84000 & 1.26 & 110 & 1.11 & 18 & 1.43 & 56 & 2 & 25.87 & 25.07 & 28338 & -59.98 & -3.05 & -2.79 & -0.29 & -1.72 & 549 & 2.54 \\
\hline
\end{tabular}


RUSSIAN RESEARCH CENTER KURCHATOV INSTITUTE

Kinetics Parameters of VVER-1000 Core with 3 MOX Lead Test Assemblies to be used for Accident Analysis Codes

Table 7. Evolution of main neutronics parameters. Second cycle with 3 MOX LTAs of "Island-2" type \{ Pu(3.8-2.8) $-\mathrm{U} 3.7 \%$

$\mathrm{Sim}=360, \mathrm{Xe}=1, \mathrm{Sm}=3$

\begin{tabular}{|c|c|c|c|c|c|c|c|c|c|c|c|c|c|c|c|c|c|c|c|c|c|c|c|}
\hline$N$ & $\begin{array}{c}\mathrm{T} \\
\text { EFPD }\end{array}$ & $\begin{array}{c}\mathrm{H}_{\text {reg. }} \\
\mathrm{cm}\end{array}$ & $\begin{array}{c}t_{\text {entry }} \\
{ }^{\circ} \mathrm{C}\end{array}$ & $\begin{array}{c}\text { W } \\
\text { MW }\end{array}$ & $\begin{array}{l}\mathrm{Cb}^{\text {crit. }} \\
\text { ppm }\end{array}$ & $\begin{array}{c}\mathbf{G} \\
\mathrm{m}^{3} / \mathrm{h}\end{array}$ & $\mathrm{Kq}$ & Nk & $\mathrm{Kq}^{\operatorname{Mox}}$ & Nk & Kv & Nk & $\mathrm{Nz}$ & $\begin{array}{c}\overline{\mathrm{B}}_{\mathbf{U}} \\
\mathrm{MW} \bullet \\
\mathrm{d} / \mathrm{kg}\end{array}$ & $\begin{array}{c}\overline{\mathrm{B}}_{\text {Mox }} \\
\mathrm{MW} \bullet \\
\mathrm{d} / \mathrm{kg}\end{array}$ & $\begin{array}{c}\mathrm{MDC} \\
\mathrm{pcm} \cdot \\
\left(\mathrm{g} / \mathrm{cm}^{3}\right)^{-1}\end{array}$ & $\begin{array}{l}\text { MTC } \\
\text { pcm॰ } \\
{ }^{\circ} \mathrm{C}^{-1}\end{array}$ & $\begin{array}{l}\text { DTC } \\
\text { pcm• } \\
{ }^{\circ} \mathrm{C}^{-1}\end{array}$ & $\begin{array}{l}\text { DTC } \\
\text { pcm• } \\
{ }^{\circ} \mathrm{C}^{-1}\end{array}$ & $\begin{array}{l}\text { DPC } \\
\text { pcm• } \\
\mathrm{MW}^{-1}\end{array}$ & $\begin{array}{c}\text { DRo/DCb } \\
\text { pcm• }^{-1} \\
\text { ppm }^{-1}\end{array}$ & $\begin{array}{c}\beta_{\text {ef. }} \\
\mathrm{pcm}\end{array}$ & $\begin{array}{l}\mathrm{l}_{\mathrm{im}} \\
\cdot 10^{5} \\
\mathrm{sec}\end{array}$ \\
\hline 1 & 0.0 & 283.2 & 287.0 & 3000 & 5658 & 84000 & 1.34 & 153 & 1.23 & 141 & 1.66 & 153 & 4 & 13.86 & 11.81 & 12366 & -25.86 & -2.87 & -2.47 & -0.28 & -1.57 & 647 & 2.25 \\
\hline 2 & 20.0 & 283.2 & 287.0 & 3000 & 5322 & 84000 & 1.28 & 153 & 1.23 & 141 & 1.55 & 153 & 4 & 14.70 & 12.86 & 12989 & -26.89 & -2.88 & -2.49 & -0.28 & -1.57 & 636 & 2.25 \\
\hline 3 & 40.0 & 283.2 & 287.0 & 3000 & 4905 & 84000 & 1.28 & 153 & 1.22 & 141 & 1.52 & 153 & 4 & 15.55 & 13.91 & 14105 & -29.20 & -2.87 & -2.51 & -0.28 & -1.57 & 628 & 2.27 \\
\hline 4 & 60.0 & 283.2 & 287.0 & 3000 & 4487 & 84000 & 1.27 & 153 & 1.21 & 141 & 1.49 & 153 & 3 & 16.40 & 14.95 & 15283 & -31.67 & -2.87 & -2.53 & -0.28 & -1.58 & 619 & 2.28 \\
\hline 5 & 80.0 & 283.2 & 287.0 & 3000 & 4061 & 84000 & 1.27 & 153 & 1.20 & 141 & 1.47 & 153 & 3 & 17.25 & 15.98 & 16492 & -34.24 & -2.87 & -2.55 & -0.28 & -1.59 & 612 & 2.30 \\
\hline 6 & 100.0 & 283.2 & 287.0 & 3000 & 3641 & 84000 & 1.26 & 153 & 1.20 & 18 & 1.45 & 47 & 3 & 18.10 & 17.00 & 17687 & -36.78 & -2.88 & -2.57 & -0.28 & -1.61 & 604 & 2.32 \\
\hline 7 & 120.0 & 283.2 & 287.0 & 3000 & 3221 & 84000 & 1.25 & 153 & 1.19 & 18 & 1.43 & 47 & 3 & 18.95 & 18.03 & 18878 & -39.34 & -2.90 & -2.60 & -0.28 & -1.62 & 597 & 2.34 \\
\hline 8 & 140.0 & 283.2 & 287.0 & 3000 & 2817 & 84000 & 1.24 & 47 & 1.19 & 18 & 1.41 & 47 & 3 & 19.80 & 19.04 & 20037 & -41.83 & -2.91 & -2.62 & -0.28 & -1.63 & 590 & 2.36 \\
\hline 9 & 160.0 & 283.2 & 287.0 & 3000 & 2413 & 84000 & 1.24 & 110 & 1.18 & 18 & 1.40 & 110 & 3 & 20.65 & 20.05 & 21192 & -44.32 & -2.93 & -2.65 & -0.28 & -1.64 & 584 & 2.38 \\
\hline 10 & 180.0 & 283.2 & 287.0 & 3000 & 2016 & 84000 & 1.24 & 110 & 1.18 & 18 & 1.40 & 110 & 2 & 21.50 & 21.06 & 22334 & -46.80 & -2.95 & -2.67 & -0.29 & -1.65 & 578 & 2.41 \\
\hline 11 & 200.0 & 283.2 & 287.0 & 3000 & 1620 & 84000 & 1.25 & 110 & 1.17 & 18 & 1.41 & 110 & 2 & 22.35 & 22.07 & 23479 & -49.29 & -2.97 & -2.70 & -0.29 & -1.67 & 572 & 2.44 \\
\hline 12 & 220.0 & 283.2 & 287.0 & 3000 & 1234 & 84000 & 1.25 & 110 & 1.17 & 18 & 1.42 & 110 & 2 & 23.20 & 23.06 & 24610 & -51.76 & -2.99 & -2.72 & -0.29 & -1.68 & 566 & 2.46 \\
\hline 13 & 240.0 & 283.2 & 287.0 & 3000 & 849 & 84000 & 1.25 & 110 & 1.17 & 18 & 1.42 & 110 & 2 & 24.05 & 24.06 & 25749 & -54.26 & -3.01 & -2.74 & -0.29 & -1.69 & 561 & 2.49 \\
\hline 14 & 260.0 & 283.2 & 287.0 & 3000 & 469 & 84000 & 1.25 & 110 & 1.16 & 18 & 1.42 & 110 & 2 & 24.90 & 25.05 & 26885 & -56.76 & -3.03 & -2.76 & -0.29 & -1.71 & 556 & 2.52 \\
\hline 15 & 280.0 & 283.2 & 287.0 & 3000 & 90 & 84000 & 1.25 & 110 & 1.16 & 18 & 1.42 & 110 & 2 & 25.75 & 26.05 & 28028 & -59.29 & -3.04 & -2.79 & -0.29 & -1.72 & 552 & 2.55 \\
\hline 16 & 284.8 & 283.2 & 287.0 & 3000 & 0 & 84000 & 1.25 & 110 & 1.16 & 18 & 1.42 & 56 & 2 & 25.95 & 26.28 & 28301 & -59.90 & -3.05 & -2.79 & -0.29 & -1.73 & 551 & 2.56 \\
\hline
\end{tabular}


RUSSIAN RESEARCH CENTER KURCHATOV INSTITUTE

Kinetics Parameters of VVER-1000 Core with 3 MOX Lead Test Assemblies to be used for Accident Analysis Codes

Table 8. Evolution of main neutronics parameters. 3-d cycle with 3 MOX LTAs 100\%Pu(4.2-3.0-2.0)

$\operatorname{Sim}=360, \mathrm{Xe}=1, \mathrm{Sm}=3$

\begin{tabular}{|c|c|c|c|c|c|c|c|c|c|c|c|c|c|c|c|c|c|c|c|c|c|c|c|}
\hline$N$ & $\begin{array}{c}\mathbf{T} \\
\text { EFPD }\end{array}$ & $\begin{array}{c}\mathrm{H}_{\text {reg. }} \\
\mathrm{cm}\end{array}$ & $\begin{array}{c}t_{\text {entry }} \\
{ }^{\circ} \mathrm{C}\end{array}$ & $\begin{array}{c}\text { W } \\
\text { MW }\end{array}$ & $\begin{array}{l}\mathrm{Cb}^{\text {crit. }} \\
\mathrm{ppm}\end{array}$ & $\begin{array}{c}\mathbf{G} \\
\mathrm{m}^{3} / \mathrm{h}\end{array}$ & $\mathrm{Kq}$ & Nk & $\mathrm{Kq}^{\mathrm{MOx}}$ & Nk & $\mathbf{K v}$ & Nk & $\mathrm{Nz}$ & $\begin{array}{c}\overline{\mathrm{B}}_{\mathbf{U}} \\
\mathrm{MW} \bullet \\
\mathrm{d} / \mathrm{kg}\end{array}$ & $\begin{array}{c}\overline{\mathrm{B}}_{\text {Mox }} \\
\mathrm{MW} \bullet \\
\mathrm{d} / \mathrm{kg}\end{array}$ & $\begin{array}{c}\text { MDC } \\
\text { pcm• } \\
\left(\mathrm{g} / \mathrm{cm}^{3}\right)^{-1}\end{array}$ & $\begin{array}{l}\text { MTC } \\
\text { pcm॰ } \\
{ }^{\circ} \mathrm{C}^{-1}\end{array}$ & $\begin{array}{l}\text { DTC } \\
\text { pcm } \\
{ }^{\circ} \mathrm{C}^{-1}\end{array}$ & $\begin{array}{l}\mathrm{DTC}^{*} \\
\mathrm{pcm} \bullet \\
{ }^{\circ} \mathrm{C}^{-1}\end{array}$ & $\begin{array}{l}\mathrm{DPC} \\
\mathrm{pcm} \bullet \\
\mathrm{MW}^{-1}\end{array}$ & $\begin{array}{c}\text { DRo/DCb } \\
\text { pcm• }^{-1} \\
\text { ppm }^{-1}\end{array}$ & $\begin{array}{l}\beta_{\text {ef. }} \\
\text { pcm }\end{array}$ & $\begin{array}{r}\mathrm{l}_{\mathrm{im}} \\
\cdot 10^{5} \\
\mathrm{sec}\end{array}$ \\
\hline 1 & 0.0 & 283.2 & 287.0 & 3000 & 5810 & 4000 & 1.33 & 126 & 1.04 & 111 & 1.64 & 126 & 4 & 13.36 & 25.07 & 11897 & -2477 & -2.89 & -2.48 & -0.28 & -1.55 & 647 & 2.23 \\
\hline 2 & 20.0 & 283.2 & 287.0 & 3000 & 5472 & 84000 & 1.28 & 11 & 1.06 & 111 & 1.54 & 126 & 4 & 14.21 & 25.96 & & -25.89 & -2.88 & -2.49 & .28 & & 636 & 2.24 \\
\hline 3 & 40.0 & 283.2 & 287.0 & 3000 & 5054 & 84000 & 1.28 & 11 & 1.05 & 111 & 1.51 & 11 & 4 & 15.06 & 26.86 & 6885 & -28.21 & -2.88 & -2.51 & -0.28 & & 628 & 2.25 \\
\hline 4 & 60.0 & 283.2 & 287.0 & 3000 & 4629 & 84000 & 1.27 & 11 & 1.05 & 111 & 1.48 & 126 & 3 & 15.91 & 27.75 & 14883 & -30.74 & -2.87 & -2.53 & -0.28 & & 620 & 2.27 \\
\hline 5 & 80.0 & 283.2 & 287.0 & 3000 & 4204 & 84000 & 1.26 & 11 & 1.04 & 111 & 1.46 & 126 & 3 & 16.76 & 28.64 & & -33.31 & -2.88 & -2.55 & & & 612 & 2.28 \\
\hline 6 & 100.0 & 283.2 & 287.0 & 3000 & 3779 & 84000 & 1.25 & 124 & 1.04 & 111 & 1.44 & 124 & 3 & 17.62 & 29.53 & 17306 & -35.90 & -2.89 & -2.57 & -0.28 & -1.59 & 604 & 2.30 \\
\hline 7 & 120.0 & 283.2 & 287.0 & 3000 & 3368 & 84000 & 1.25 & 124 & 1.04 & 111 & 1.44 & 124 & 3 & 18.47 & 30.42 & & -38 & -2.90 & -2.60 & & & 597 & 2.32 \\
\hline 8 & 140.0 & 283.2 & 287.0 & 3000 & 2958 & 84000 & 1.25 & 124 & 1.04 & 111 & 1.43 & 124 & 3 & 19.32 & 31.30 & & -40 & -2.91 & -2.62 & & & 91 & 2.34 \\
\hline 9 & 160.0 & 283.2 & 287.0 & 3000 & 2547 & 84000 & 1.25 & 124 & 1.04 & 111 & 1.42 & 124 & 3 & 20.17 & 32.18 & 20833 & -43.48 & -2.93 & -2.64 & -0.28 & -1.63 & 84 & 2.37 \\
\hline 10 & 180.0 & 283.2 & 287.0 & 3000 & 2150 & 84000 & 1.25 & 124 & 1.04 & 111 & 1.42 & 124 & 2 & 21.02 & 33.07 & 21979 & -45.97 & -2.95 & -2.67 & -0.29 & -1.64 & 578 & 2.39 \\
\hline 11 & 200.0 & 283.2 & 287.0 & 3000 & 1754 & 84000 & 1.25 & 134 & 1.04 & 111 & 1.42 & 124 & 2 & 21.88 & 33.95 & 23129 & -48.47 & -2.97 & -2.69 & -0.29 & -1.66 & 572 & 2.42 \\
\hline 12 & 220.0 & 283.2 & 287.0 & 3000 & 1357 & 84000 & 1.25 & 134 & 1.04 & 111 & 1.42 & 124 & 2 & 22.73 & 34.83 & 24284 & -51.00 & -2.99 & -2.72 & -0.29 & -1.67 & 567 & 2.45 \\
\hline 13 & 240.0 & 283.2 & 287.0 & 3000 & 974 & 84000 & 1.25 & 134 & 1.04 & 111 & 1.42 & 124 & 2 & 23.58 & 35.72 & 25422 & -53.50 & -3.01 & -2.74 & -0.29 & -1.69 & 561 & 2.47 \\
\hline 14 & 260.0 & 283.2 & 287.0 & 3000 & 591 & 84000 & 1.25 & 134 & 1.04 & 111 & 1.42 & 134 & 2 & 24.43 & 36.60 & 26568 & -56.03 & -3.02 & -2.76 & -0.29 & & 557 & 2.50 \\
\hline 15 & 280.0 & 283.2 & 287.0 & 3000 & 208 & 84000 & 1.25 & 134 & 1.04 & 111 & 1.42 & 134 & 2 & 25.28 & 37.49 & 27720 & -58.58 & -3.04 & -2.78 & -0.29 & -1.71 & 552 & 2.53 \\
\hline 16 & 291.0 & 283.2 & 287.0 & 3000 & 0 & 84000 & 1.25 & 134 & 1.04 & 111 & 1.42 & 134 & 2 & 25.75 & 37.97 & 28351 & -59.99 & -3.05 & -2.79 & -0.29 & -1.72 & 550 & 2.55 \\
\hline
\end{tabular}


RUSSIAN RESEARCH CENTER KURCHATOV INSTITUTE

Kinetics Parameters of VVER-1000 Core with 3 MOX Lead Test Assemblies to be used for Accident Analysis Codes

Table 9. Evolution of main neutronics parameters. 3-d cycle with 3 MOX LTAs of “Island-2” type \{ Pu(3.8-2.8) U3.7\%\}

$\mathrm{Sim}=360, \mathrm{Xe}=1, \mathrm{Sm}=3$

\begin{tabular}{|c|c|c|c|c|c|c|c|c|c|c|c|c|c|c|c|c|c|c|c|c|c|c|c|}
\hline$N^{n}$ & $\begin{array}{c}\mathrm{T} \\
\text { EFPD }\end{array}$ & $\begin{array}{c}\mathrm{H}_{\text {reg. }} \\
\mathrm{cm}\end{array}$ & $\begin{array}{c}\mathrm{t}_{\text {entry }} \\
{ }^{\circ} \mathrm{C}\end{array}$ & $\begin{array}{c}\text { W } \\
\text { MW }\end{array}$ & $\begin{array}{c}\mathrm{Cb}^{\text {erit. }} \\
\mathrm{ppm}\end{array}$ & $\begin{array}{c}\mathbf{G} \\
\mathrm{m}^{3} / \mathrm{h}\end{array}$ & $\mathrm{Kq}$ & Nk & $\mathrm{Kq}^{\mathbf{M O X}}$ & Nk & $\mathrm{Kv}$ & Nk & $\mathrm{Nz}$ & $\begin{array}{c}\bar{B}_{\mathrm{U}} \\
\mathrm{MW} \bullet \\
\mathrm{d} / \mathrm{kg}\end{array}$ & $\begin{array}{l}\overline{\mathrm{B}}_{\text {Mox }} \\
\text { MW० } \\
\mathrm{d} / \mathrm{kg}\end{array}$ & $\begin{array}{c}\mathrm{MDC} \\
\mathrm{pcm} \cdot \\
\left(\mathrm{g} / \mathrm{cm}^{3}\right)^{-1}\end{array}$ & $\begin{array}{l}\text { MTC } \\
\mathrm{pcm} \cdot \\
{ }^{\circ} \mathrm{C}^{-1}\end{array}$ & $\begin{array}{l}\text { DTC } \\
\text { pcm. } \\
{ }^{\circ} \mathrm{C}^{-1}\end{array}$ & $\begin{array}{l}\text { DTC } \\
\text { pcm- } \\
{ }^{\circ} \mathrm{C}^{-1}\end{array}$ & $\begin{array}{l}\text { DPC } \\
\text { pcm• } \\
\mathrm{MW}^{-1}\end{array}$ & $\begin{array}{c}\mathrm{DRo} / \mathrm{DCb} \\
\mathrm{pcm}^{\bullet} \\
\mathrm{ppm}^{-1}\end{array}$ & $\begin{array}{l}\beta_{\text {ef. }} \\
\text { pcm }\end{array}$ & $\begin{array}{l}l_{\mathrm{im}} \\
\cdot 10^{5} \\
\sec \end{array}$ \\
\hline 1 & 0.0 & & 7.0 & 000 & & 000 & & 126 & & 111 & 64 & 126 & 4 & 13.41 & 6.28 & 11833 & -2463 & -2.89 & -2.49 & -0.28 & -1.56 & 48 & 2.24 \\
\hline 2 & & & & & & & & & & & & 12 & 4 & 26 & & & & & & & & & .25 \\
\hline 4 & & 33.2 & 77.0 & & & 1000 & 1.27 & 124 & & 11 & 48 & 12 & & & & & & & & & & & 2.28 \\
\hline 5 & 80.0 & 283.2 & 287.0 & 3000 & 4193 & 4000 & 1.27 & 124 & 1.05 & 111 & 1.47 & 124 & 3 & 16.82 & 29.85 & 012 & & 2.89 & -2. & 0.28 & 1.59 & 13 & 2.29 \\
\hline 6 & 100.0 & & 37.0 & & 3770 & 000 & 1.27 & 124 & 1.04 & & 1.46 & 124 & & & & & & & & & & & 2.31 \\
\hline 10 & 180.0 & 283.2 & 287.0 & 000 & $214^{7}$ & 000 & 1.26 & 124 & 1.0 & 11 & 1.43 & 124 & & 21.08 & & & & & & & & & 2.40 \\
\hline 11 & & & & & & & & & & & & & & & & & & & & & & & 2.43 \\
\hline 12 & $2 ?$ & 3.2 & 7.0 & & & & 1.26 & 124 & & 11 & & 12 & & & & & & & & & & & 2.46 \\
\hline 13 & 240.0 & 283.2 & 7.0 & & & & 1.2 & 124 & & 11 & & 12 & & & & & & & & & & & 2.49 \\
\hline 14 & & & & & & & & 124 & & & & & & & & & & & & & & & 2.51 \\
\hline 15 & 280.0 & 3.2 & 77.0 & & 210 & & 1.26 & 124 & 1.06 & 111 & 1.44 & 124 & 2 & 25.34 & 8.78 & & & 04 & 98 & & -1.72 & 3 & 2.54 \\
\hline 16 & 291.2 & 283.2 & 287.0 & 000 & 0 & 84000 & 1.26 & 124 & 1.06 & 111 & 1.43 & 124 & 2 & 25.81 & 39.28 & 28277 & -59.82 & -3.05 & -2.79 & -0.29 & -1.73 & 551 & 2.56 \\
\hline
\end{tabular}


Table 10. Power Peaking Factors Attained During Fuel Cycle

\begin{tabular}{|c|c|c|c|c|c|c|c|c|}
\hline & & Uranium & MOX-1 & & MOX-2 & & MOX-3 & \\
\hline & & & $100 \% \mathrm{Pu}$ & Island & $100 \% \mathrm{Pu}$ & Island & $100 \% \mathrm{Pu}$ & Island \\
\hline & $\mathrm{BOC}$ & 1.86 & 1.79 & 1.79 & 1.85 & 1.84 & 1.83 & 1.82 \\
\hline $\mathrm{K}_{\mathrm{tatan}}$ & $\mathrm{EOC}$ & 1.52 & 1.52 & 1.51 & 1.49 & 1.48 & 1.46 & 1.47 \\
\hline & $\max$ & 1.86 & 1.79 & 1.79 & 1.85 & 1.84 & 1.83 & 1.82 \\
\hline & $\mathrm{BOC}$ & 19 & 38 & 38 & 153 & 141 & 126 & 126 \\
\hline $\mathrm{N}\left(\mathrm{K}_{\mathrm{t}, \mathrm{ta}}\right)$ & EOC & 19 & 124 & 124 & 56 & 56 & 134 & 124 \\
\hline & $\max$ & 19 & 38 & 38 & 153 & 141 & 126 & 126 \\
\hline & BOC & 4 & 4 & 4 & 4 & 4 & 4 & 4 \\
\hline $\mathrm{M}\left(\mathrm{K}_{\mathrm{a}-\mathrm{tata})}\right)$ & EOC & 2 & 2 & 2 & 2 & 2 & 2 & 2 \\
\hline & $\max$ & 4 & 4 & 4 & 4 & 4 & 4 & 4 \\
\hline & BOC & 1.51 & 1.47 & 1.47 & 1.49 & 1.52 & 1.48 & 1.48 \\
\hline $\mathrm{Kr}$ & EOC & 1.34 & 1.33 & 1.32 & 1.31 & 1.31 & 1.29 & 1.30 \\
\hline & $\max$ & 1.51 & 1.47 & 1.47 & 1.49 & 1.52 & 1.48 & 1.48 \\
\hline & BOC & 19 & 38 & 38 & 153 & 141 & 126 & 126 \\
\hline $\mathrm{N}(\mathrm{Kr})$ & EOC & 6 & 124 & 124 & 110 & 18 & 152 & 124 \\
\hline & $\max$ & 19 & 38 & 38 & 153 & 141 & 126 & 126 \\
\hline
\end{tabular}

$\square$ - Power Peaking Factor is attained in MOX LTA 
Table 11. Core Subcriticality (Scram Margin) in different states in the process of Scram actuation

\begin{tabular}{|c|c|c|c|c|c|c|c|c|c|c|c|c|c|}
\hline \multicolumn{6}{|c|}{ State parameters } & \multicolumn{8}{|c|}{ RO, pcm } \\
\hline \multirow{2}{*}{ 咅家 } & \multirow{2}{*}{$\sum^{k}$} & \multirow{2}{*}{$\stackrel{\circ}{\circ}$} & \multirow[t]{2}{*}{$\stackrel{00}{0}$} & \multirow{2}{*}{ 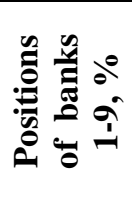 } & \multirow{2}{*}{ 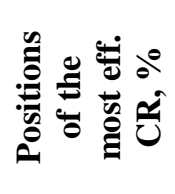 } & \multicolumn{2}{|c|}{ UOX } & \multicolumn{2}{|c|}{$\begin{array}{c}\text { MOX } \\
\text { 1er } \\
\text { cycle }\end{array}$} & \multicolumn{2}{|c|}{$\begin{array}{c}\text { MOX } \\
\text { 2nd } \\
\text { cycle }\end{array}$} & \multicolumn{2}{|c|}{$\begin{array}{c}\text { MOX } \\
\text { 3d } \\
\text { cycle }\end{array}$} \\
\hline & & & & & & BOC & EOC & BOC & EOC & BOC & EOC & BOC & EOC \\
\hline \multirow[t]{2}{*}{1} & 3000 & Nominal. & 100 & 100 & 100 & +522 & +605 & +483 & +600 & +434 & +563 & +449 & +569 \\
\hline & \multicolumn{13}{|c|}{ Regulation margin of reactivity } \\
\hline \multirow[t]{2}{*}{2} & 3000 & Nominal. & 50 & 100 & 100 & 0. & 0. & 0. & 0. & 0. & 0. & 0. & 0. \\
\hline & \multicolumn{13}{|c|}{ Scram actuation without sticking of the most effective CR } \\
\hline \multirow[t]{2}{*}{3} & 3000 & Nominal. & 0 & 0 & 0 & -8833 & -9136 & -8772 & -9043 & -8806 & -9064 & -8994 & -9150 \\
\hline & \multicolumn{13}{|c|}{ Scram actuation with sticking of the most effective CR } \\
\hline \multirow[t]{2}{*}{4} & 3000 & Nominal. & 0 & 0 & 100 & -7970 & -8262 & -7964 & -8178 & -7889 & -8153 & -8671 & -8282 \\
\hline & \multicolumn{13}{|c|}{ Doppler effect } \\
\hline \multirow[t]{2}{*}{5} & 0 & Nominal. & 0 & 0 & 100 & -6391 & -6807 & -6989 & -7296 & -6865 & -7244 & -7628 & -7379 \\
\hline & \multicolumn{13}{|c|}{ Moderator temperature effect } \\
\hline \multirow[t]{2}{*}{6} & 0 & 287 & 0 & 0 & 100 & -5550 & -5088 & -5718 & -5001 & -5609 & -5000 & -6488 & -5192 \\
\hline & \multicolumn{13}{|c|}{ Moderator temperature effect } \\
\hline \multirow[t]{2}{*}{7} & 0 & 280 & 0 & 0 & 100 & -5358 & -4711 & -5530 & -4624 & -5417 & -4624 & -6294 & -4817 \\
\hline & \multicolumn{13}{|c|}{ Vapor effect $(\Delta \rho=50 \mathrm{pcm})$} \\
\hline \multirow[t]{2}{*}{8} & 0 & 280 & 0 & 0 & 100 & -5308 & -4661 & -5480 & -4574 & -5367 & -4574 & -6244 & -4767 \\
\hline & \multicolumn{13}{|c|}{ Uncertainty of (RO) $)_{\mathrm{AP}}$ calculation ( $10 \%$ of p. 4 ) } \\
\hline \multirow[t]{2}{*}{9} & 0 & 280 & 0 & 0 & 100 & -4511 & -3835 & -4684 & -3756 & -4578 & -3759 & -5377 & -3939 \\
\hline & \multicolumn{13}{|c|}{ Uncertainty of temperature effect calculation $(\Delta \rho=180 \mathrm{pcm})$} \\
\hline 10 & 0 & 280 & 0 & 0 & 100 & -4331 & -3655 & -4504 & -3576 & -4398 & -3579 & -5197 & -3759 \\
\hline & Absorb & nt irradia & on effe & $(\Delta \rho=1$ & $00 \mathrm{pcm})$ & & & & & & & & \\
\hline 11 & 0 & 280 & 0 & 0 & 100 & -4231 & -3555 & -4404 & -3476 & -4298 & -3479 & -5097 & -3659 \\
\hline
\end{tabular}


Kinetics Parameters of VVER-1000 Core with 3 MOX Lead Test Assemblies to be used for Accident Analysis Codes

Table 12. Control Rods Worth $\left(\mathrm{RO}_{\mathrm{AP}-1}\right)$ for Uranium core and MOX cores

\begin{tabular}{|l|c|c|c|c|}
\hline & $\begin{array}{c}\text { Uranium } \\
\text { Core }\end{array}$ & $\begin{array}{c}\text { First cycle } \\
\text { with } 3 \text { MOX } \\
\text { LTAs }\end{array}$ & $\begin{array}{c}\text { 2-nd cycle } \\
\text { with } 3 \text { MOX } \\
\text { LTAs }\end{array}$ & $\begin{array}{c}\text { 3-d cycle } \\
\text { with 3 MOX } \\
\text { LTAs }\end{array}$ \\
\hline BOC & $\mathbf{8 3 3 0}$ & 8300 & 8180 & 8930 \\
\hline EOC & $\mathbf{8 5 7 0}$ & 8480 & 8430 & 8560 \\
\hline
\end{tabular}


RUSSIAN RESEARCH CENTER KURCHATOV INSTITUTE

Kinetics Parameters of VVER-1000 Core with 3 MOX Lead Test Assemblies to be used for Accident Analysis Codes

Table 13. Core reactivity in the process of control rods movement

\begin{tabular}{|c|c|c|c|c|c|c|c|c|c|c|c|}
\hline \multirow{3}{*}{$\begin{array}{l}T, \\
S\end{array}$} & \multirow{3}{*}{$\begin{array}{c}\text { AP } \\
\text { Position,\% } \\
\text { (Hreg=80\%) }\end{array}$} & \multicolumn{10}{|c|}{ BOC } \\
\hline & & \multicolumn{2}{|c|}{ Uranium } & \multicolumn{4}{|c|}{ MOX-1 } & \multicolumn{2}{|c|}{ MOX-2 } & \multicolumn{2}{|c|}{ MOX-3 } \\
\hline & & No stuck & $\begin{array}{c}\text { Stuck } \\
\text { N } 55\end{array}$ & $\begin{array}{c}\text { No } \\
\text { stuck } \\
100 \%\end{array}$ & $\begin{array}{c}\text { No } \\
\text { stuck } \\
\text { Island }\end{array}$ & $\begin{array}{c}\text { Stuck } \\
\text { N } 67 \\
100 \%\end{array}$ & $\begin{array}{l}\text { Stuck } \\
\text { N } 67 \\
\text { Island }\end{array}$ & $\begin{array}{c}\text { No } \\
\text { stuck }\end{array}$ & $\begin{array}{l}\text { Stuck } \\
\text { N } 109\end{array}$ & $\begin{array}{c}\text { No } \\
\text { stuck }\end{array}$ & $\begin{array}{l}\text { Stuck } \\
\text { N } 112\end{array}$ \\
\hline 0 & 100 & 0 & 0 & 0 & 0 & 0 & 0 & 0 & 0 & 0 & 0 \\
\hline 0,4 & 90 & -120 & -120 & -120 & -120 & -120 & -120 & -110 & -110 & -120 & -120 \\
\hline 0,8 & 80 & -210 & -210 & -210 & -210 & -210 & -210 & -200 & -200 & -200 & -200 \\
\hline 1,2 & 70 & -310 & -310 & -310 & -310 & -310 & -310 & -290 & -290 & -300 & -300 \\
\hline 1,6 & 60 & -460 & -460 & -450 & -450 & -450 & -450 & -430 & -430 & -440 & -440 \\
\hline 2,0 & 50 & -700 & -700 & -680 & -690 & -680 & -680 & -660 & -660 & -680 & -670 \\
\hline 2,4 & 40 & -1150 & -1140 & -1110 & -1110 & -1100 & -1110 & -1070 & -1070 & -1090 & -1090 \\
\hline 2,8 & 30 & -2000 & -1990 & -1920 & -1920 & -1910 & -1920 & -1860 & -1850 & -1900 & -1890 \\
\hline 3,2 & 20 & -3620 & -3590 & -3490 & -3500 & -3470 & -3480 & -3430 & -3400 & -3480 & -3460 \\
\hline 3,6 & 10 & -7050 & -6810 & -6930 & -6950 & -6730 & -6740 & -6900 & -6660 & -7010 & -6880 \\
\hline 4,0 & 0 & -9150 & -8330 & -9060 & -9070 & -8300 & -8300 & -9060 & -8180 & -9250 & -8930 \\
\hline
\end{tabular}

\begin{tabular}{|c|c|c|c|c|c|c|c|c|c|c|c|}
\hline \multirow{3}{*}{$\begin{array}{l}\mathrm{T}, \\
\mathbf{S}\end{array}$} & \multirow{3}{*}{$\begin{array}{c}\text { AP } \\
\text { Position,\% } \\
\text { (Hreg=80\%) }\end{array}$} & \multicolumn{10}{|c|}{ EOC } \\
\hline & & \multicolumn{2}{|c|}{ Uranium } & \multicolumn{4}{|c|}{ MOX-1 } & \multicolumn{2}{|c|}{ MOX-2 } & \multicolumn{2}{|c|}{ MOX-3 } \\
\hline & & No stuck & $\begin{array}{c}\text { Stuck } \\
\text { N } 55\end{array}$ & $\begin{array}{c}\text { No } \\
\text { stuck } \\
100 \%\end{array}$ & $\begin{array}{l}\text { No } \\
\text { stuck } \\
\text { Island }\end{array}$ & $\begin{array}{c}\text { Stuck } \\
\text { N 97 } \\
100 \%\end{array}$ & $\begin{array}{l}\text { Stuck } \\
\text { N } 97 \\
\text { Island }\end{array}$ & $\begin{array}{c}\text { No } \\
\text { stuck }\end{array}$ & $\begin{array}{c}\text { Stuck } \\
\text { N } 97\end{array}$ & $\begin{array}{c}\text { No } \\
\text { stuck }\end{array}$ & $\begin{array}{c}\text { Stuck } \\
\text { N } 97\end{array}$ \\
\hline 0 & 100 & 0 & 0 & 0 & 0 & 0 & 0 & 0 & 0 & 0 & 0 \\
\hline 0,4 & 90 & -140 & -140 & -140 & -140 & -140 & -140 & -130 & -130 & -140 & -140 \\
\hline 0,8 & 80 & -190 & -190 & -190 & -190 & -190 & -190 & -190 & -190 & -190 & -190 \\
\hline 1,2 & 70 & -260 & -260 & -260 & -260 & -260 & -250 & -250 & -250 & -260 & -260 \\
\hline 1,6 & 60 & -360 & -360 & -360 & -350 & -360 & -350 & -350 & -350 & -350 & -350 \\
\hline 2,0 & 50 & -530 & -530 & -530 & -530 & -530 & -530 & -520 & -520 & -530 & -530 \\
\hline 2,4 & 40 & -880 & -870 & -870 & -870 & -870 & -860 & -850 & -850 & -860 & -860 \\
\hline 2,8 & 30 & -1590 & -1580 & -1570 & -1570 & -1570 & -1560 & -1540 & -1530 & -1540 & -1540 \\
\hline 3,2 & 20 & -3000 & -2980 & -2960 & -2950 & -2940 & -2930 & -2910 & -2890 & -2910 & -2890 \\
\hline 3,6 & 10 & -6300 & -6160 & -6200 & -6190 & -6060 & -6050 & -6180 & -6020 & -6190 & -6060 \\
\hline 4,0 & 0 & -9410 & -8570 & -9310 & -9310 & -8480 & -8480 & -9310 & -8430 & -9400 & -8560 \\
\hline
\end{tabular}


RUSSIAN RESEARCH CENTER KURCHATOV INSTITUTE

Kinetics Parameters of VVER-1000 Core with 3 MOX Lead Test Assemblies to be used for Accident Analysis Codes

Table 14. Core reactivity versus regulation group position

\begin{tabular}{|c|c|c|c|c|c|c|c|c|}
\hline Hreg, \% & \multicolumn{4}{|c|}{ BOC } & \multicolumn{4}{|c|}{ EOC } \\
\hline & U & MOX1 & MOX2 & MOX3 & U & MOX1 & MOX2 & MOX3 \\
\hline 100 & 210 & 200 & 180 & 180 & 350 & 350 & 330 & 330 \\
\hline 90 & 130 & 130 & 120 & 120 & 200 & 200 & 190 & 190 \\
\hline 80 & 10 & 10 & 10 & 10 & 0 & 0 & 0 & 0 \\
\hline 70 & -120 & -110 & -100 & -100 & -140 & -140 & -130 & -130 \\
\hline 60 & -240 & -220 & -190 & -200 & -250 & -250 & -230 & -240 \\
\hline 50 & -350 & -310 & -280 & -290 & -330 & -330 & -310 & -320 \\
\hline 40 & -450 & -400 & -360 & -380 & -410 & -400 & -380 & -390 \\
\hline 30 & -540 & -490 & -440 & -460 & -470 & -470 & -440 & -440 \\
\hline 20 & -620 & -560 & -500 & -520 & -520 & -520 & -490 & -500 \\
\hline 10 & -680 & -610 & -550 & -580 & -570 & -570 & -540 & -550 \\
\hline 0 & -700 & -630 & -570 & -600 & -590 & -600 & -560 & -570 \\
\hline
\end{tabular}


RUSSIAN RESEARCH CENTER KURCHATOV INSTITUTE

Kinetics Parameters of VVER-1000 Core with 3 MOX Lead Test Assemblies to be used for Accident Analysis Codes

Table 15. Core Reactivity Versus Coolant Density

\begin{tabular}{|c|c|c|c|c|c|c|c|c|}
\hline & \multicolumn{2}{|c|}{ UOX } & \multicolumn{2}{|c|}{ MOX -1st cycle } & \multicolumn{2}{|c|}{ MOX -2nd cycle } & \multicolumn{2}{|c|}{ MOX -3d cycle } \\
\hline & BOC & EOC & & & & & & \\
\hline & $\begin{array}{l}\text { CB=8730 } \\
\text { ppm, } \\
\text { Hreg=100\% }\end{array}$ & $\begin{array}{l}\text { CB=3530 } \\
\text { ppm, } \\
\text { Hreg=100\% }\end{array}$ & $\begin{array}{l}\text { CB=8870 } \\
\text { ppm, } \\
\text { Hreg=100\% }\end{array}$ & \begin{tabular}{|l|}
$\mathrm{CB}=3580$ \\
ppm, \\
Hreg=100\%
\end{tabular} & $\begin{array}{l}\text { CB=8730 } \\
\text { ppm, } \\
\text { Hreg=100\% } \\
\end{array}$ & \begin{tabular}{|l|}
$\mathrm{CB}=3540$ \\
ppm, \\
Hreg=100\%
\end{tabular} & \begin{tabular}{|l|}
$\mathrm{CB}=8860$ \\
ppm, \\
Hreg=100\%
\end{tabular} & $\begin{array}{l}\text { CB }=3550 \\
\text { ppm, } \\
\text { Hreg }=100 \%\end{array}$ \\
\hline $\begin{array}{c}\text { Density, } \\
\text { G/cm3 }\end{array}$ & \multicolumn{8}{|c|}{ RO, pcm } \\
\hline 0.2 & -26696 & -41633 & -26699 & -41431 & -27067 & -41477 & -26883 & -41552 \\
\hline 0.4 & -7353 & -14144 & -7358 & -14067 & -7555 & -14112 & -7446 & -14148 \\
\hline 0.6 & -1449 & -3978 & -1467 & -3961 & -1548 & -3986 & -1490 & -3994 \\
\hline 0.766 & 0 & 0 & 0 & 0 & 0 & 0 & 0 & 0 \\
\hline
\end{tabular}


Table 16. Core Reactivity versus Core Power and Average Core Fuel Temperature (Doppler Effect), pcm

\begin{tabular}{|c|c|c|c|c|c|c|c|c|c|c|c|c|c|}
\hline \multirow{2}{*}{$\begin{array}{c}\text { Power, } \\
\text { MW }\end{array}$} & \multirow{2}{*}{$\begin{array}{c}\mathbf{t}_{\text {fuel }} \\
\mathrm{K}\end{array}$} & \multicolumn{4}{|c|}{ BOC, Xe eq, Hreg=80\% } & \multicolumn{4}{|c|}{ EOC, Xe eq, Hreg=80\% } & \multicolumn{4}{|c|}{ EOC, $\mathrm{Xe}=0$, Hreg $=80 \%$} \\
\hline & & UOX & $\begin{array}{c}\text { MOX } \\
1 \\
\text { cycle }\end{array}$ & $\begin{array}{c}\text { MOX } \\
2 \\
2 \\
\text { cycle }\end{array}$ & $\begin{array}{c}\text { MOX } \\
3 \\
3 \\
\text { cycle }\end{array}$ & UOX & $\begin{array}{c}\text { MOX } \\
1 \\
1 \\
\text { cycle }\end{array}$ & $\begin{array}{c}\text { MOX } \\
2 \\
\text { cycle }\end{array}$ & $\begin{array}{c}\text { MOX } \\
3 \\
3 \\
\text { cycle }\end{array}$ & UOX & $\begin{array}{c}\text { MOX } \\
1 \\
\text { cycle }\end{array}$ & $\begin{array}{c}\text { MOX } \\
2 \\
2 \\
\text { cycle }\end{array}$ & $\begin{array}{c}\text { MOX } \\
3 \\
\text { cycle }\end{array}$ \\
\hline 6000 & 1207 & -709 & -701 & -701 & -702 & -703 & -698 & -696 & -700 & 2316 & 2317 & 2315 & 2313 \\
\hline 5400 & 1146 & -592 & -584 & -583 & -585 & -585 & -580 & -578 & -581 & 2428 & 2428 & 2427 & 2425 \\
\hline 4800 & 1085 & -463 & -456 & -456 & -457 & -455 & -451 & -449 & -452 & 2549 & 2549 & 2548 & 2546 \\
\hline 4500 & 1055 & -394 & -387 & -387 & -388 & -386 & -382 & -380 & -384 & 2614 & 2614 & 2612 & 2611 \\
\hline 3900 & 994 & -245 & -240 & -240 & -240 & -239 & -236 & -234 & -237 & 2753 & 2752 & 2750 & 2748 \\
\hline 3600 & 963 & -165 & -161 & -161 & -161 & -161 & -159 & -157 & -160 & 2827 & 2825 & 2823 & 2821 \\
\hline 3300 & 933 & -81 & -78 & -78 & -78 & -79 & -78 & -77 & -79 & 2903 & 2901 & 2898 & 2897 \\
\hline 3000 & 902 & 0 & 0 & 0 & 0 & 0 & 0 & 0 & 0 & 2983 & 2973 & 2971 & 2972 \\
\hline 2700 & 871 & 99 & 98 & 98 & 98 & 92 & 91 & 93 & 90 & 3065 & 3055 & 3052 & 3053 \\
\hline 2400 & 839 & 194 & 191 & 192 & 192 & 183 & 180 & 182 & 179 & 3150 & 3139 & 3136 & 3137 \\
\hline 1800 & 775 & 398 & 389 & 390 & 390 & 372 & 367 & 368 & 364 & 3329 & 3316 & 3312 & 3312 \\
\hline 1200 & 711 & 617 & 601 & 602 & 603 & 573 & 565 & 565 & 561 & 3519 & 3503 & 3498 & 3498 \\
\hline 600 & 645 & 854 & 829 & 831 & 831 & 786 & 775 & 773 & 770 & 3720 & 3702 & 3695 & 3695 \\
\hline 300 & 612 & 979 & 949 & 952 & 952 & 897 & 886 & 883 & 879 & 3826 & 3806 & 3799 & 3799 \\
\hline 0 & 579 & 1112 & 1076 & 1079 & 1080 & 1013 & 1000 & 996 & 992 & 3936 & 3915 & 3907 & 3906 \\
\hline
\end{tabular}


Table 17. Assembly Axial Relative Power Distribution for Uranium Reference Core. Equilibrium Cycle

\begin{tabular}{|c|c|c|c|c|c|c|}
\hline \multirow{2}{*}{$\begin{array}{c}\text { Axial } \\
\text { position, } \\
\mathrm{cm}\end{array}$} & \multicolumn{3}{|c|}{ BOC } & \multicolumn{3}{|c|}{ EOC } \\
\hline & $\begin{array}{l}\text { 1st year } \\
\text { (N17) }\end{array}$ & $\begin{array}{c}\text { 2nd year } \\
\text { (N15) }\end{array}$ & $\begin{array}{c}\text { 3d year } \\
\text { (N16) }\end{array}$ & $\begin{array}{l}\text { 1st year } \\
\text { (N17) }\end{array}$ & $\begin{array}{c}\text { 2nd year } \\
\text { (N15) }\end{array}$ & $\begin{array}{c}\text { 3d year } \\
\text { (N16) }\end{array}$ \\
\hline 337.250 & 0.472 & 0.520 & 0.530 & 0.688 & 0.756 & 0.777 \\
\hline 301.750 & 0.837 & 0.858 & 0.866 & 1.010 & 1.028 & 1.041 \\
\hline 266.250 & 1.012 & 1.026 & 1.020 & 1.043 & 1.045 & 1.041 \\
\hline 230.750 & 1.114 & 1.119 & 1.111 & 1.036 & 1.028 & 1.023 \\
\hline 195.250 & 1.182 & 1.170 & 1.166 & 1.038 & 1.020 & 1.014 \\
\hline 159.750 & 1.223 & 1.194 & 1.192 & 1.050 & 1.023 & 1.017 \\
\hline 124.250 & 1.234 & 1.189 & 1.190 & 1.072 & 1.034 & 1.029 \\
\hline 88.750 & 1.202 & 1.153 & 1.155 & 1.107 & 1.064 & 1.059 \\
\hline 53.250 & 1.072 & 1.061 & 1.059 & 1.124 & 1.107 & 1.102 \\
\hline 17.750 & 0.653 & 0.709 & 0.715 & 0.832 & 0.895 & 0.897 \\
\hline
\end{tabular}


Table 18. Axial Relative Power Distribution in MOX Assemblies

\begin{tabular}{|c|c|c|c|c|c|c|}
\hline $\begin{array}{c}\text { Axial } \\
\text { position, } \\
\text { cm }\end{array}$ & \multicolumn{3}{|c|}{ BOC } & \multicolumn{3}{c|}{ EOC } \\
\cline { 2 - 7 } & $\begin{array}{c}\mathbf{1} \\
\text { Cycle }\end{array}$ & $\begin{array}{c}\mathbf{2} \\
\text { Cycle }\end{array}$ & $\begin{array}{c}\mathbf{3} \\
\text { Cycle }\end{array}$ & $\begin{array}{c}\mathbf{1} \\
\text { Cycle }\end{array}$ & $\begin{array}{c}\mathbf{2} \\
\text { Cycle }\end{array}$ & $\begin{array}{c}\mathbf{3} \\
\text { Cycle }\end{array}$ \\
\hline $\mathbf{3 3 7 . 2 5 0}$ & 0.499 & 0.510 & 0.528 & 0.725 & 0.737 & 0.724 \\
\hline $\mathbf{3 0 1 . 7 5 0}$ & 0.877 & 0.859 & 0.848 & 1.043 & 1.027 & 0.979 \\
\hline $\mathbf{2 6 6 . 2 5 0}$ & 1.032 & 1.012 & 1.040 & 1.052 & 1.041 & 1.040 \\
\hline $\mathbf{2 3 0 . 7 5 0}$ & 1.117 & 1.104 & 1.134 & 1.036 & 1.029 & 1.037 \\
\hline $\mathbf{1 9 5 . 2 5 0}$ & 1.172 & 1.166 & 1.178 & 1.033 & 1.028 & 1.033 \\
\hline $\mathbf{1 5 9 . 7 5 0}$ & 1.206 & 1.203 & 1.192 & 1.039 & 1.033 & 1.037 \\
\hline $\mathbf{1 2 4 . 2 5 0}$ & 1.214 & 1.211 & 1.178 & 1.055 & 1.049 & 1.050 \\
\hline $\mathbf{8 8 . 7 5 0}$ & 1.182 & 1.179 & 1.136 & 1.085 & 1.080 & 1.079 \\
\hline $\mathbf{5 3 . 2 5 0}$ & 1.057 & 1.071 & 1.046 & 1.108 & 1.111 & 1.116 \\
\hline $\mathbf{1 7 . 7 5 0}$ & 0.641 & 0.687 & 0.718 & 0.823 & 0.863 & 0.904 \\
\hline
\end{tabular}


Table 19. Minimum effectiveness of Regulation group versus its positioning, pcm

\begin{tabular}{|l|l|l|l|l|l|l|l|l|l|l|}
\hline Hreg, \% & $\mathbf{9 0}$ & $\mathbf{8 0}$ & $\mathbf{7 0}$ & $\mathbf{6 0}$ & $\mathbf{5 0}$ & $\mathbf{4 0}$ & $\mathbf{3 0}$ & $\mathbf{2 0}$ & $\mathbf{1 0}$ & $\mathbf{0}$ \\
\hline $\begin{array}{l}\text { Standard “Conservative curve" } \\
\text { for VVER-1000 uranium core }\end{array}$ & 40 & 100 & 170 & 240 & 320 & 390 & 460 & 520 & 580 & 620 \\
\hline Base Uranium core & 80 & 200 & 330 & 450 & 560 & 660 & 750 & 830 & 890 & 910 \\
\hline Cores with 3 MOX LTAs & 60 & 170 & 280 & 370 & 460 & 540 & 620 & 680 & 730 & 750 \\
\hline
\end{tabular}


Table 20. Relative Core Reactivity Evolution in the Process of Control Rods Movement

\begin{tabular}{|l|l|l|l|l|l|l|l|l|l|l|}
\hline Insertion in core, \% & $\mathbf{1 0}$ & $\mathbf{2 0}$ & $\mathbf{3 0}$ & $\mathbf{4 0}$ & $\mathbf{5 0}$ & $\mathbf{6 0}$ & $\mathbf{7 0}$ & $\mathbf{8 0}$ & $\mathbf{9 0}$ & $\mathbf{1 0 0}$ \\
\hline $\begin{array}{l}\text { Standard "Conservative curve" } \\
\text { for VVER-1000 uranium core }\end{array}$ & 0.01 & 0.02 & 0.03 & 0.05 & 0.07 & 0.11 & 0.19 & 0.36 & 0.74 & 1.00 \\
\hline Base Uranium Core & 0.02 & 0.03 & 0.04 & 0.06 & 0.09 & 0.14 & 0.24 & 0.43 & 0.82 & 1.00 \\
\hline Core with 3 MOX LTAs & 0.01 & 0.03 & 0.04 & 0.05 & 0.08 & 0.13 & 0.23 & 0.42 & 0.81 & 1.00 \\
\hline
\end{tabular}


Kinetics Parameters of VVER-1000 Core with 3 MOX Lead Test Assemblies to be used for Accident Analysis Codes

Table 21. Conservative Curves for Assembly Axial Power Distribution

\begin{tabular}{|l|l|l|l|l|l|l|l|l|l|l|}
\hline $\begin{array}{l}\text { Axial Position, } \\
\%\end{array}$ & 5 & 15 & 25 & 35 & 45 & 55 & 65 & 75 & 85 & 95 \\
\hline $\begin{array}{l}\text { Relative power, } \\
\text { BOC }\end{array}$ & 0.36 & 0.82 & 1.12 & 1.31 & 1.39 & 1.39 & 1.31 & 1.12 & 0.82 & 0.36 \\
\hline $\begin{array}{l}\text { Relative power } \\
\text { EOC }\end{array}$ & 0.74 & 1.00 & 1.01 & 1.00 & 1.01 & 1.03 & 1.08 & 1.13 & 1.10 & 0.90 \\
\hline
\end{tabular}


RUSSIAN RESEARCH CENTER KURCHATOV INSTITUTE

Kinetics Parameters of VVER-1000 Core with 3 MOX Lead Test Assemblies to be used for Accident Analysis Codes

Table 22. Conservative Curve for Core Reactivity Versus Coolant Density

\begin{tabular}{|l|l|l|l|l|l|l|l|}
\hline Density, g/cc & 0.2 & 0.3 & 0.4 & 0.5 & 0.6 & 0.7 & 0.8 \\
\hline $\begin{array}{l}\text { Reactivity, } \\
\text { pcm }\end{array}$ & -20000 & -8600 & -4200 & -1800 & -600 & -200 & 0 \\
\hline
\end{tabular}


RUSSIAN RESEARCH CENTER KURCHATOV INSTITUTE

Kinetics Parameters of VVER-1000 Core with 3 MOX Lead Test Assemblies to be used for Accident Analysis Codes

Table 23. Conservative Curve for Linear Fuel Pin Power

\begin{tabular}{|l|l|l|l|l|l|l|l|l|l|l|}
\hline Axial layer & 1 & 2 & 3 & 4 & 5 & 6 & 7 & 8 & 9 & 10 \\
\hline $\begin{array}{l}\text { Linear Fuel } \\
\text { Pin Power, } \\
\text { W/cm }\end{array}$ & 448 & 448 & 448 & 448 & 448 & 428 & 392 & 360 & 338 & 316 \\
\hline
\end{tabular}


RUSSIAN RESEARCH CENTER KURCHATOV INSTITUTE

Kinetics Parameters of VVER-1000 Core with 3 MOX Lead Test Assemblies to be used for Accident Analysis Codes

Table 24. Decay rates of delayed neutrons

\begin{tabular}{|l|l|l|l|l|l|l|}
\hline Group & 1 & 2 & 3 & 4 & 5 & 6 \\
\hline Decay rate, 1/s & 0.0124 & 0.0305 & 0.111 & 0.301 & 1.13 & 3 \\
\hline
\end{tabular}


Fig.1. Equilibrium Loading Pattern for Uranium Reference Core with Boron BPRs. Core $60^{\circ}$ Sector

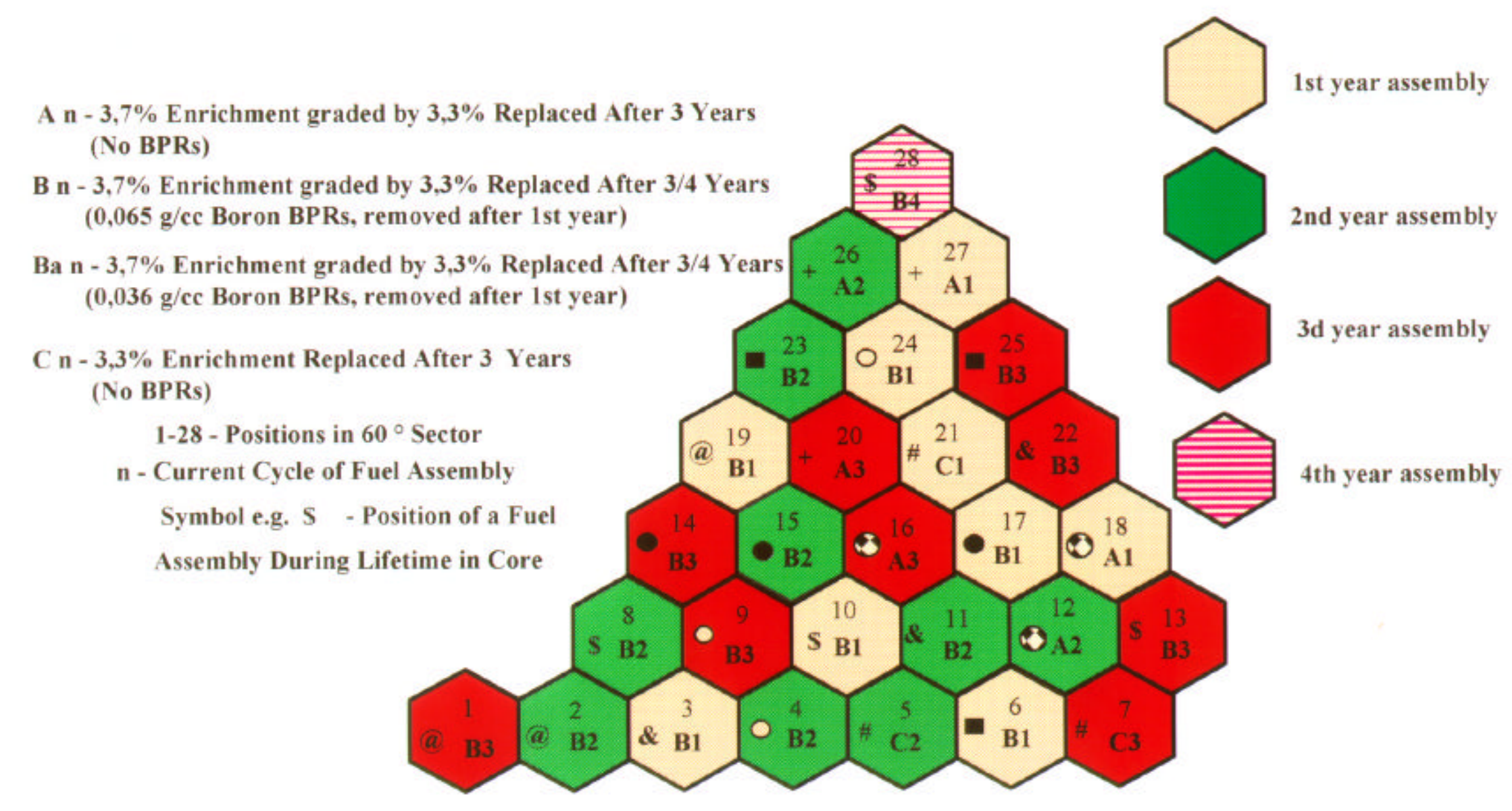


RUSSIAN RESEARCH CENTER KURCHATOV INSTITUTE

Kinetics Parameters of VVER-1000 Core with 3 MOX Lead Test Assemblies to be used for Accident Analysis Codes

Fig.2. ßeff Evolution During Core Fuel Cycle for Uranium and MOX Cores

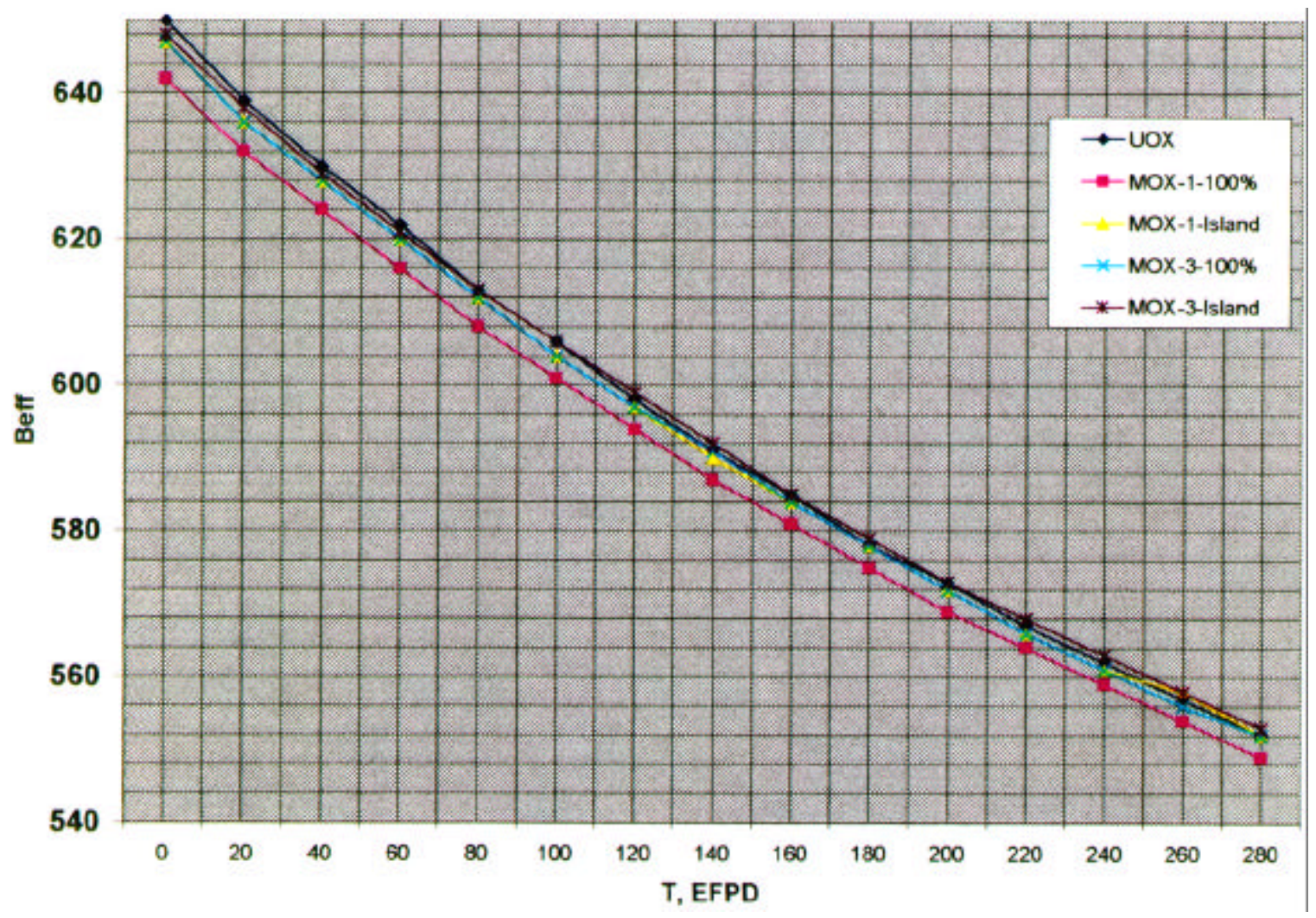


Fig.3. Core Reactivity Evolution in the Process Of Control Rods Movement for Uranium and MOX cores in BOC

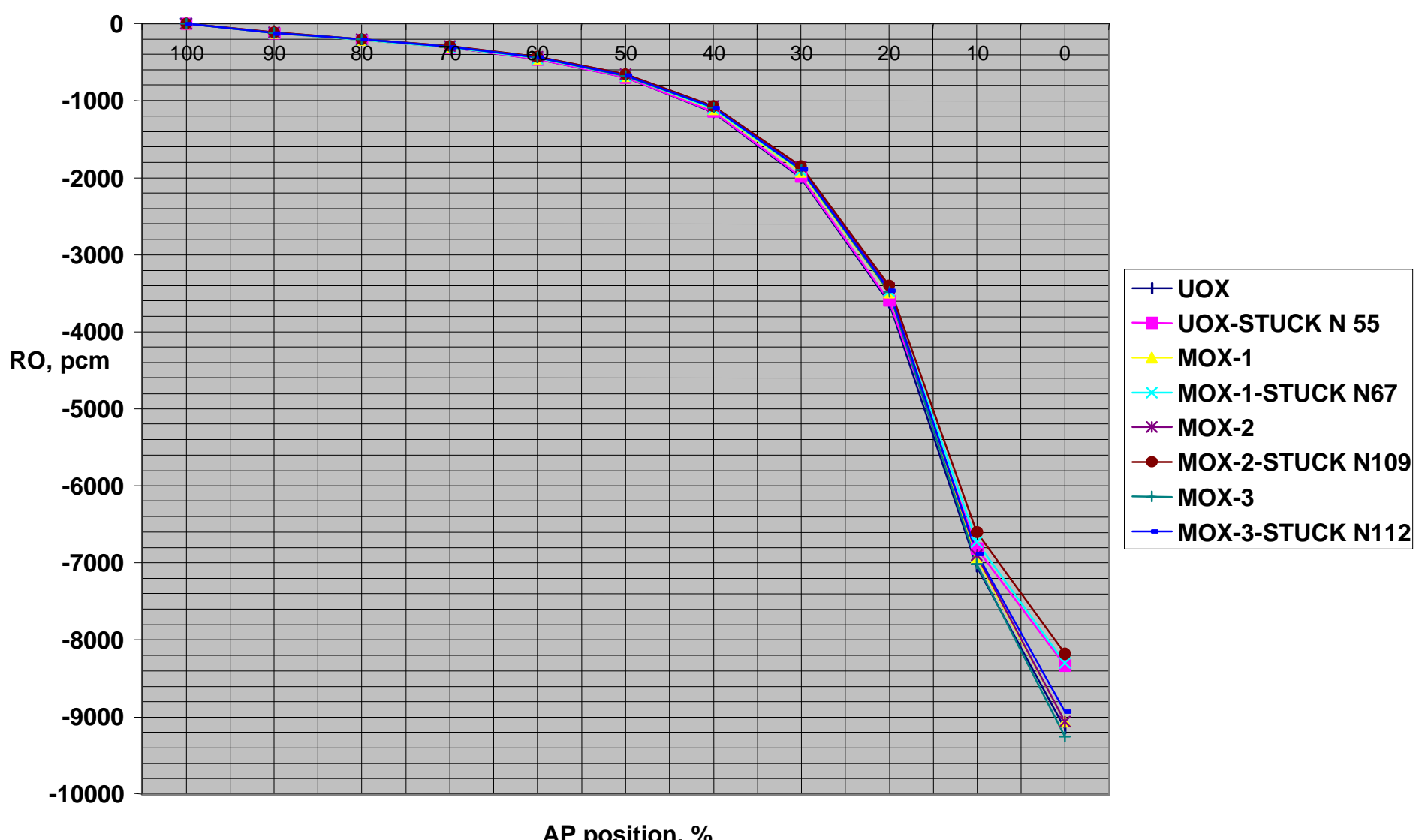


Fig.3a. Core Reactivity Evolution in the Process Of Control Rods Movement for Uranium and MOX cores in EOC

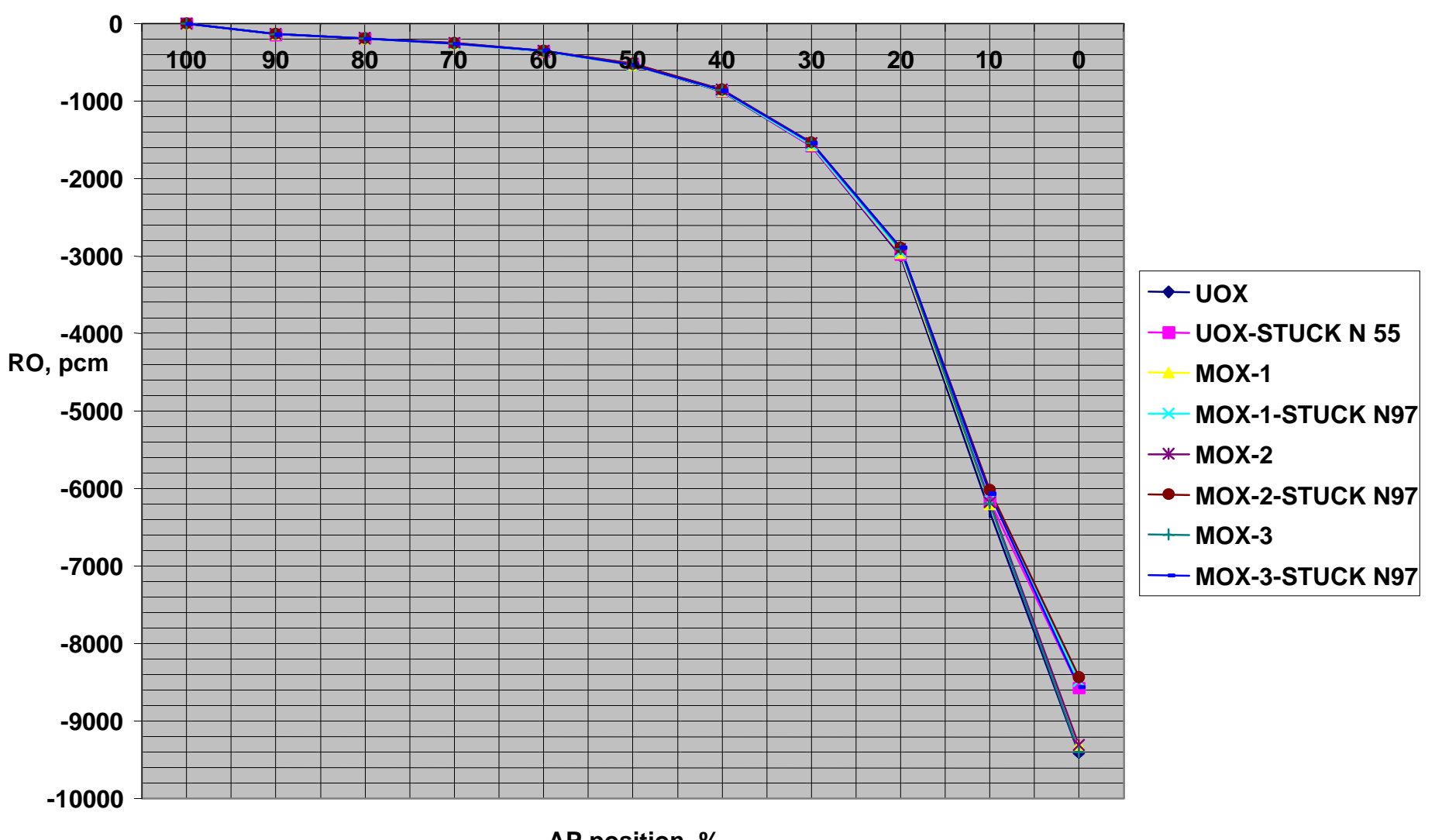


Figure 4. Core Reactivity Versus Regulating Group Position in BOC

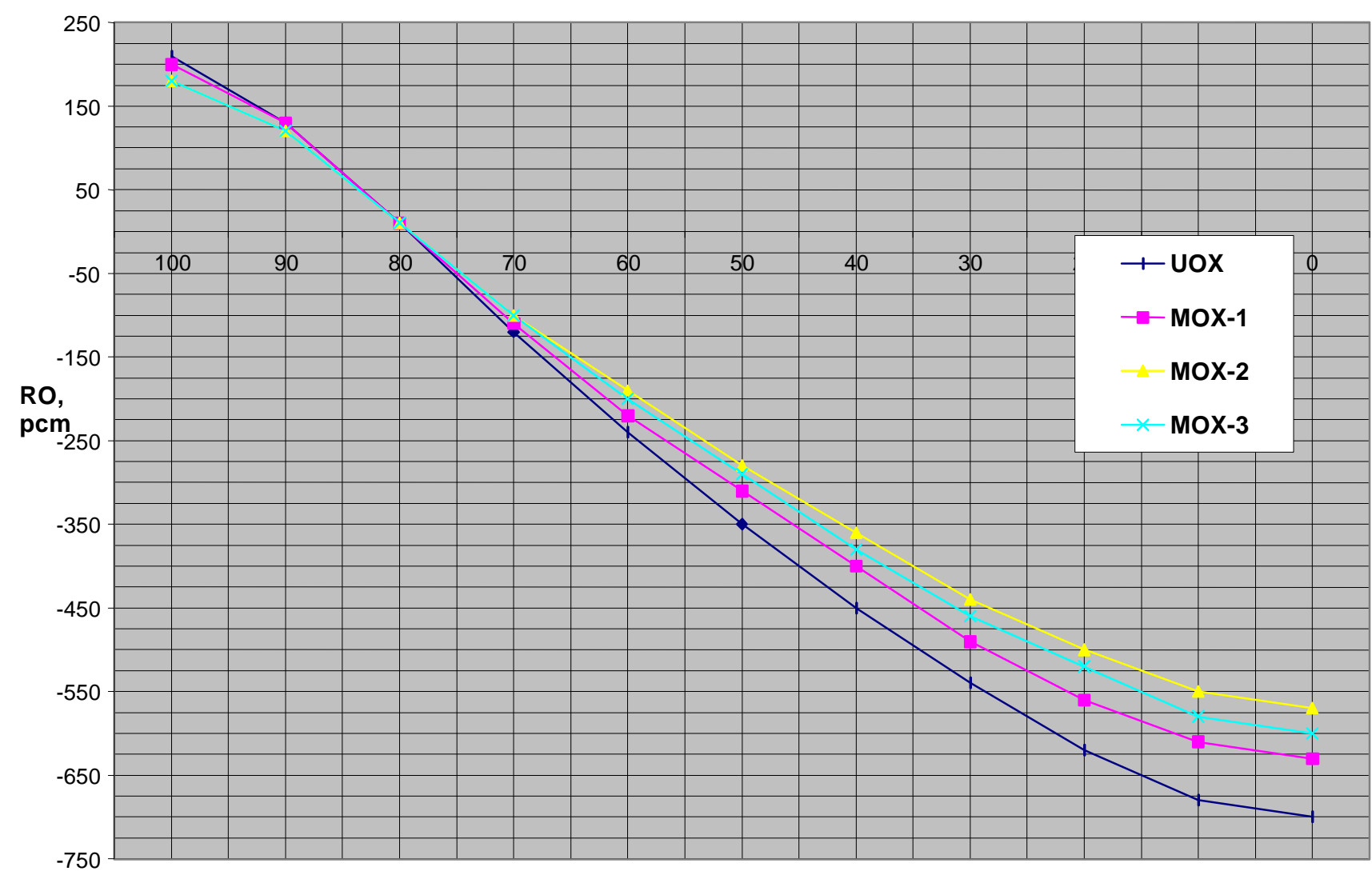

Hreg, \% 
Figure 4a. Core Reactivity Versus Regulating Group Position in EOC

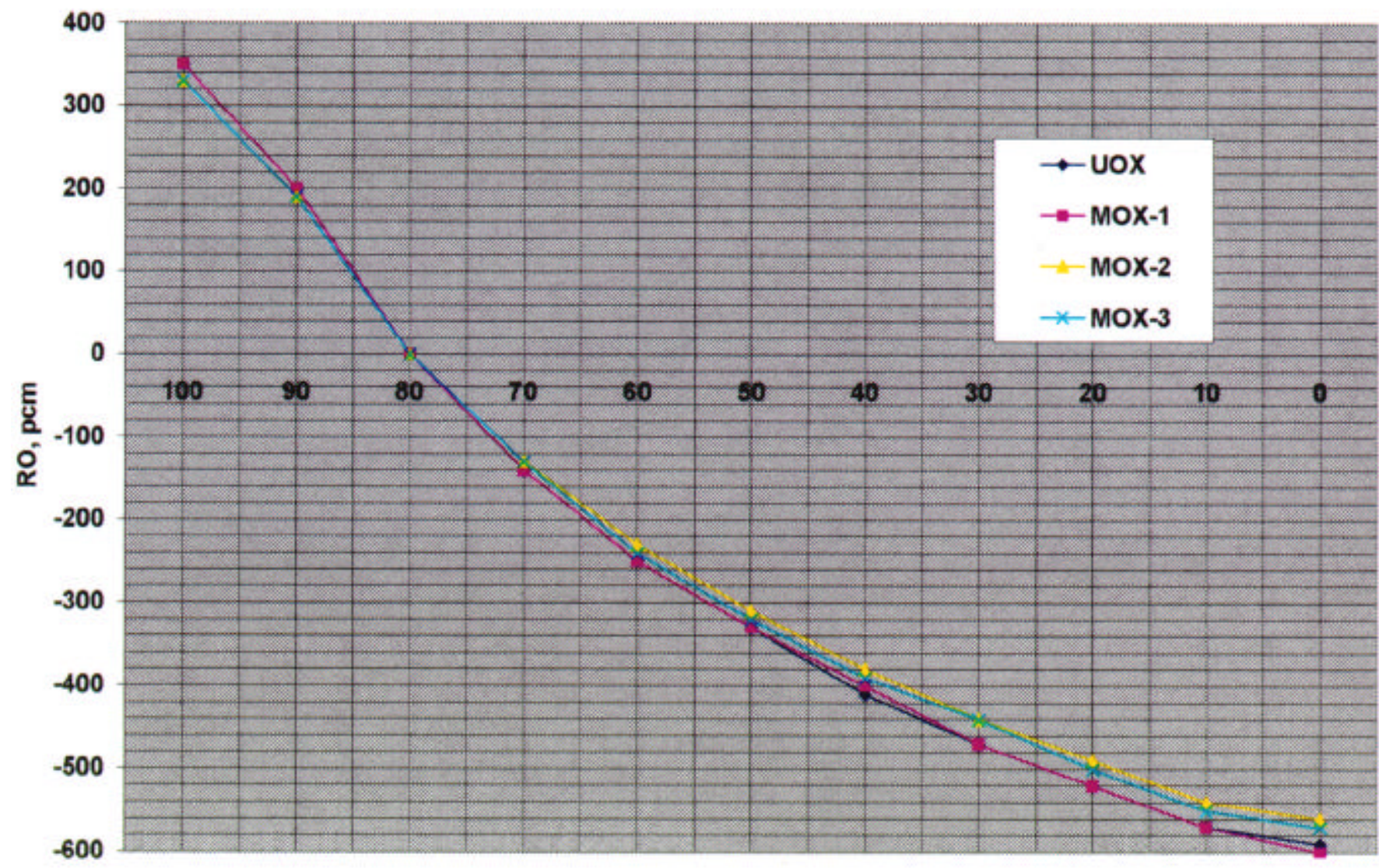

Hreg, \% 
Fig.5. Core Reactivity Versus Coolant Density

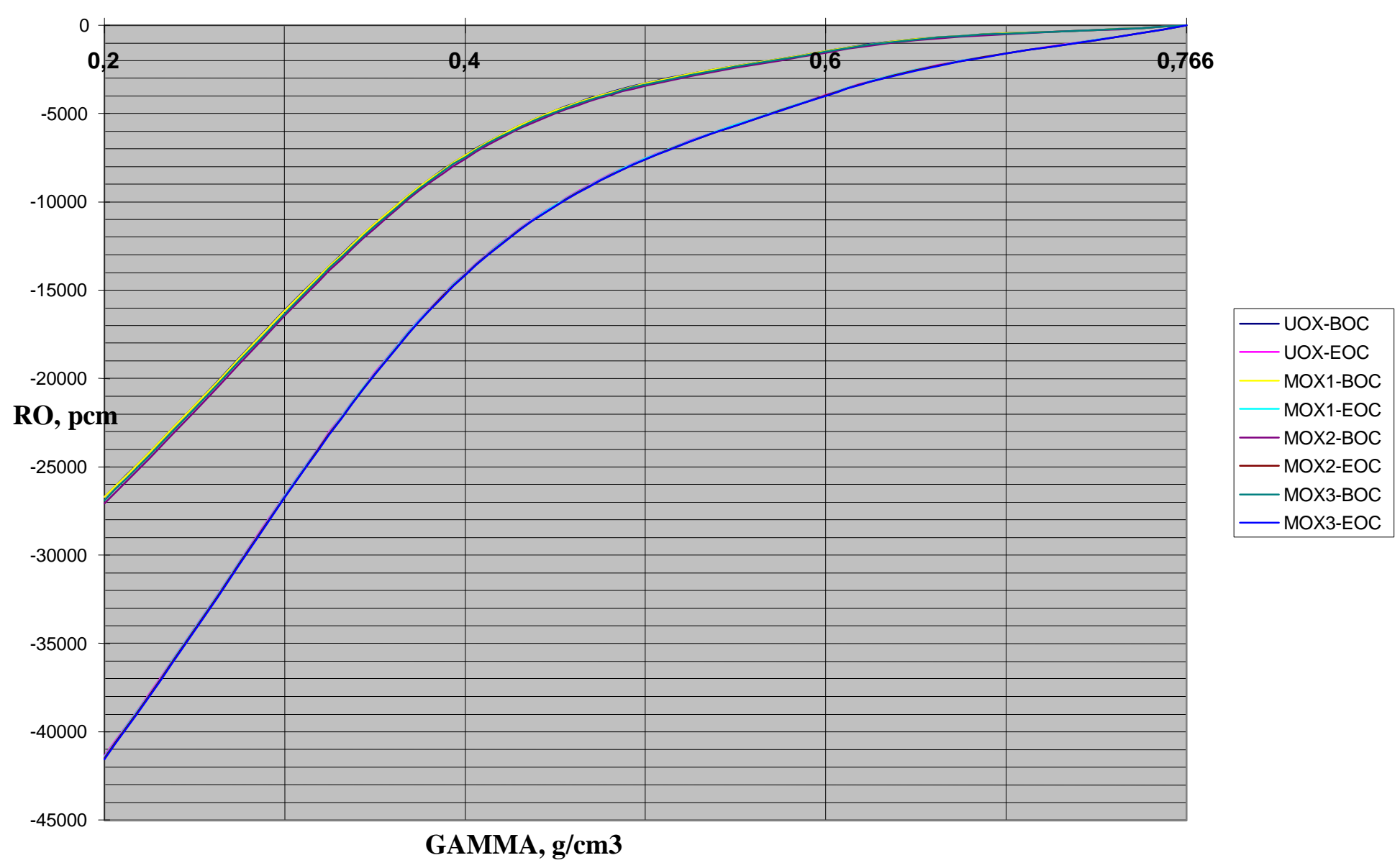


Fig.6. Core Reactivity Versus Fuel Temperature in BOC

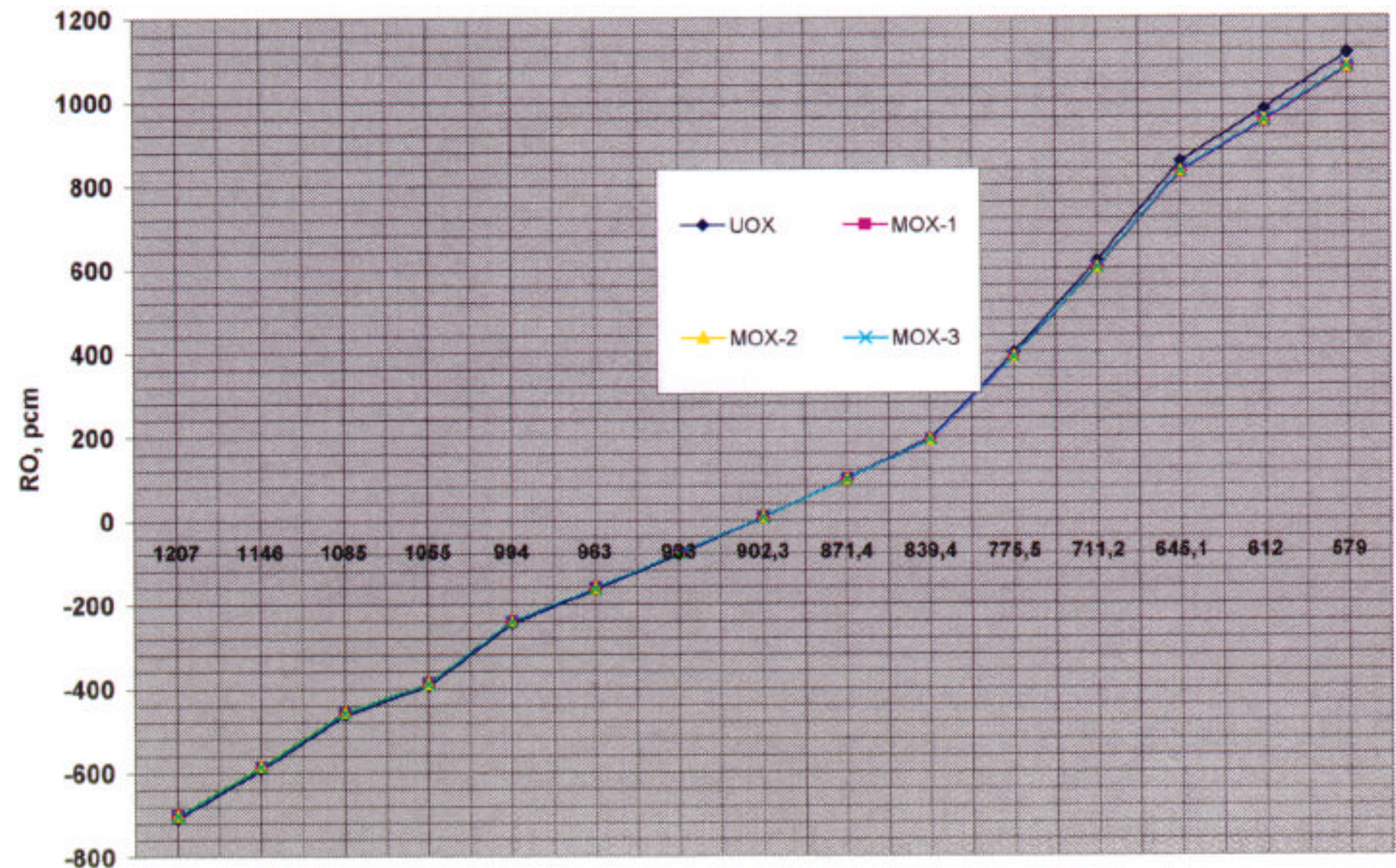

Tfuel, $\mathrm{K}$ 
Fig.6a. Core Reactivity Versus Fuel Temperature in EOC

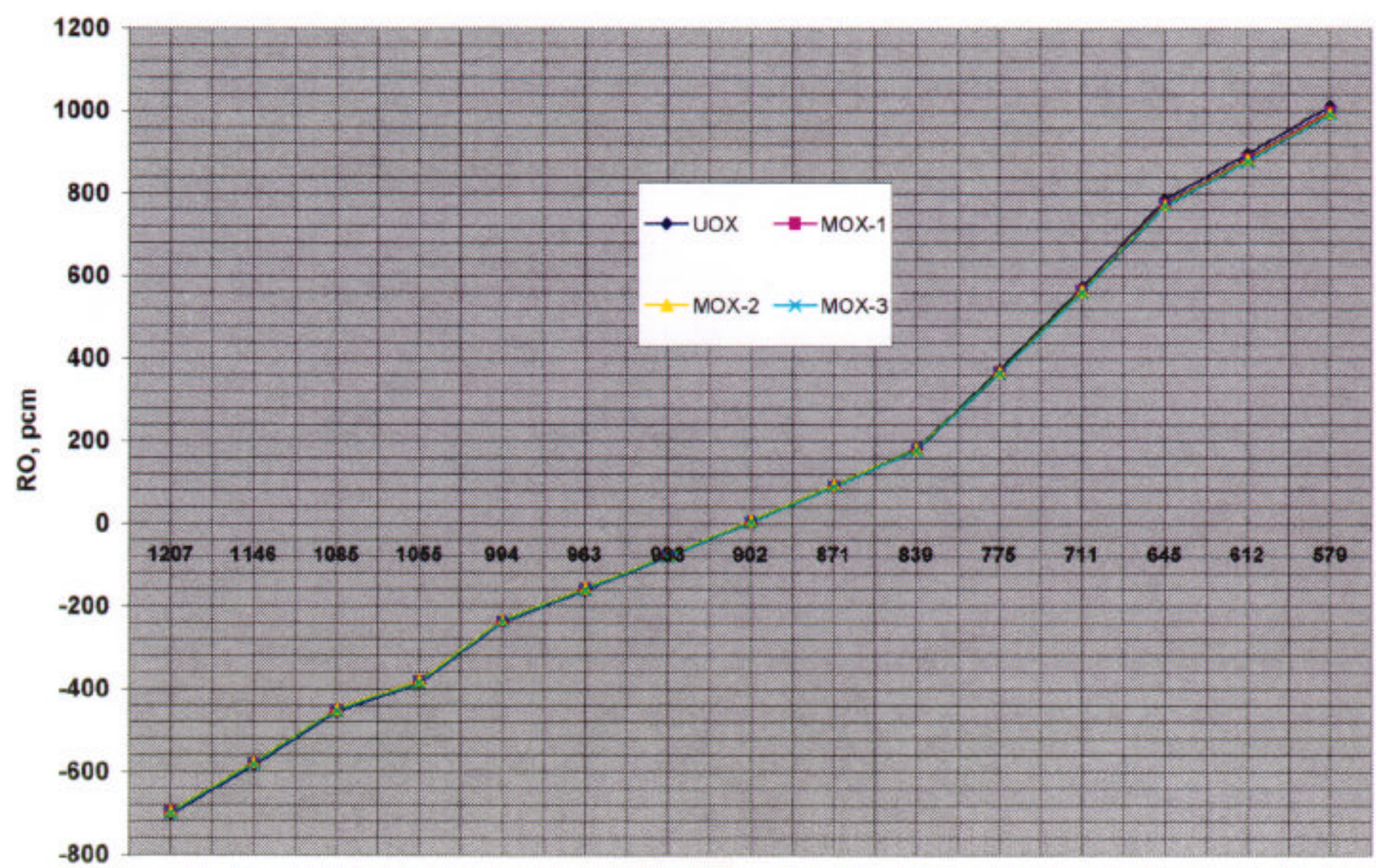

Tfuel, $\mathbf{K}$ 
Fig.7. Assembly Axial Power Distribution for Uranium Reference Core. Equilibrium Cycle

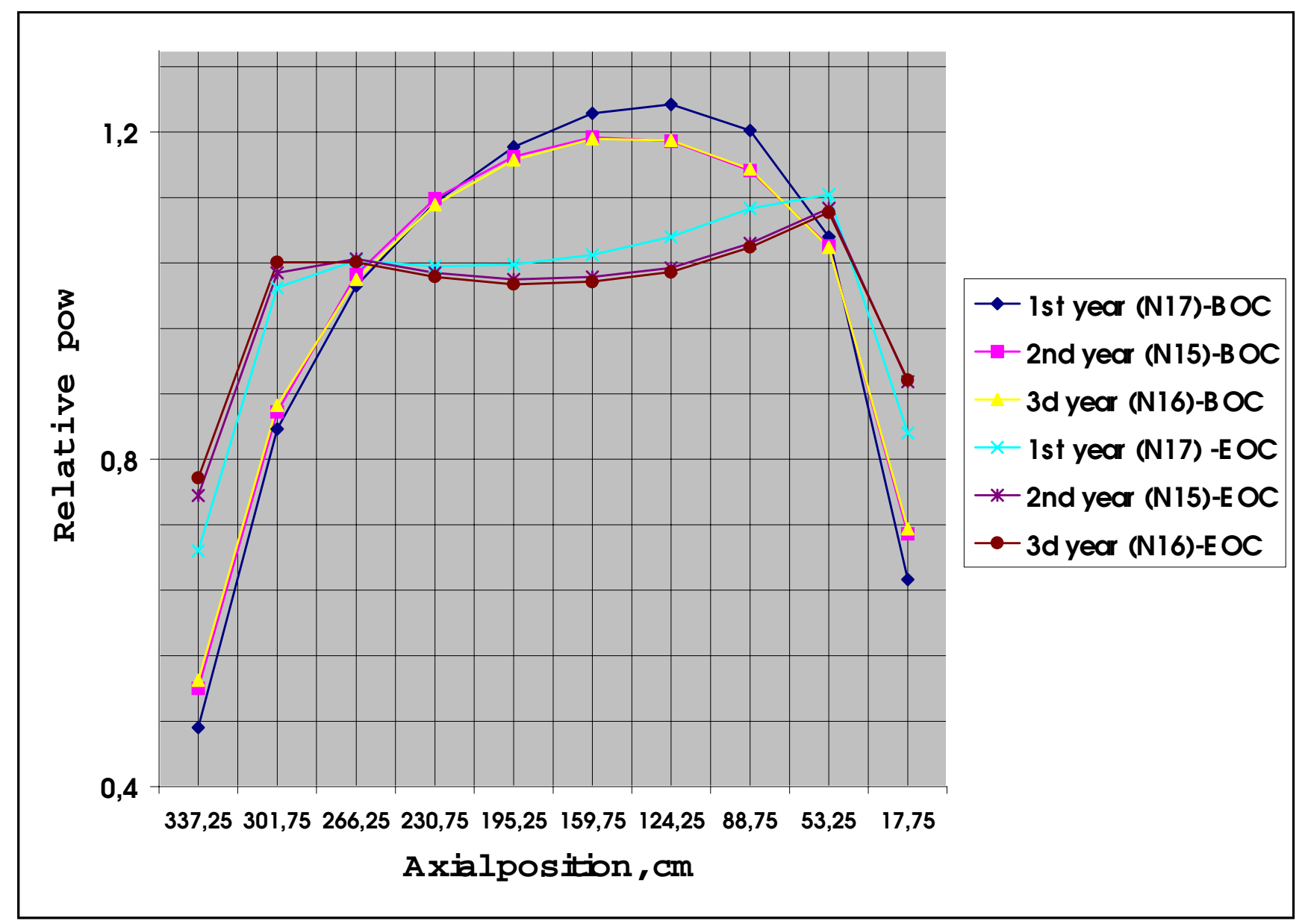


Fig.7a. Axial Power Distribution in MOX LTAs

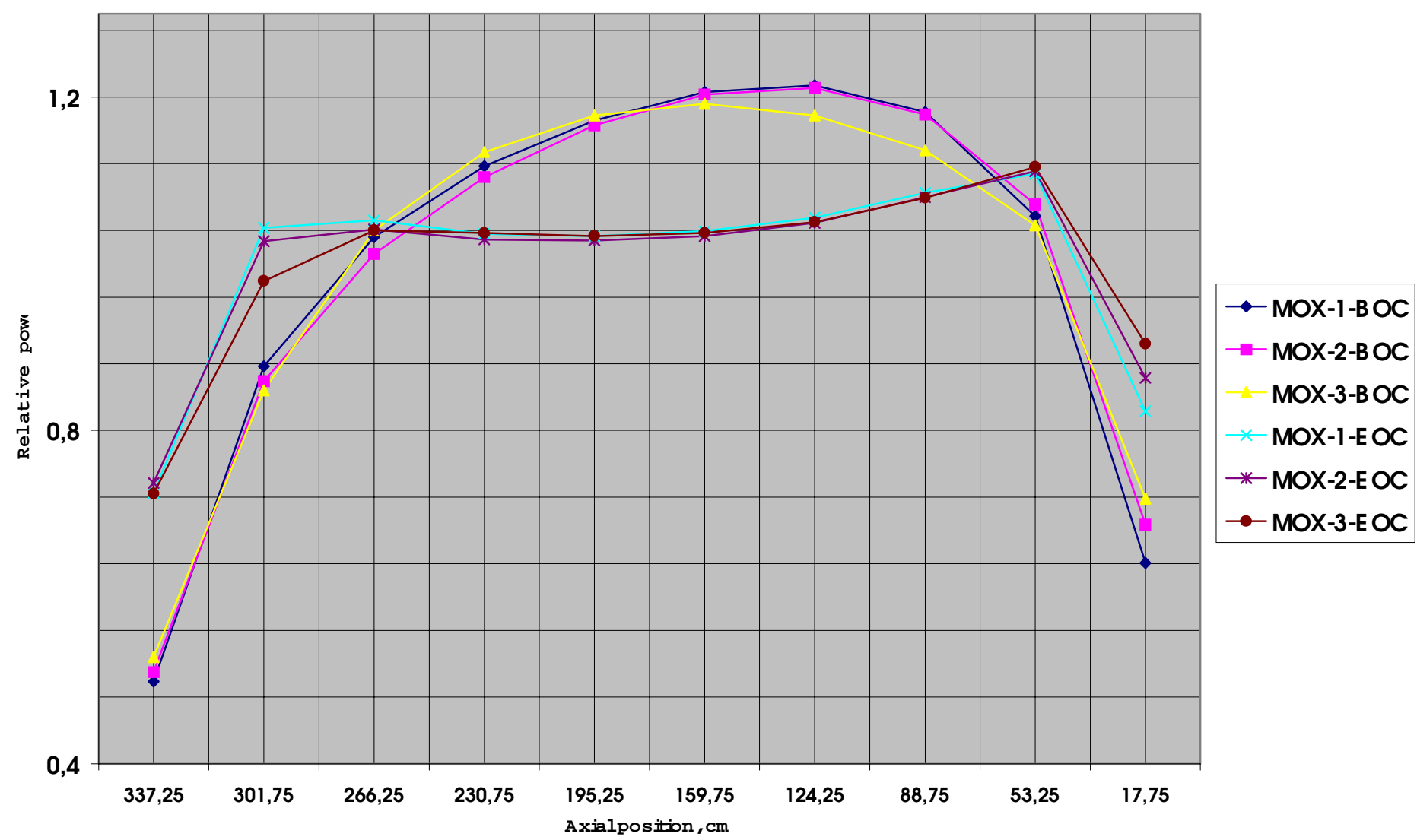


Fig.8. Assembly-by-Assembly Burnup, Power and Temperature Drops Distributions. Equilibrium Cycle for Uranium Reference Core with Boron BPRs.Core $60^{\circ}$ Sector

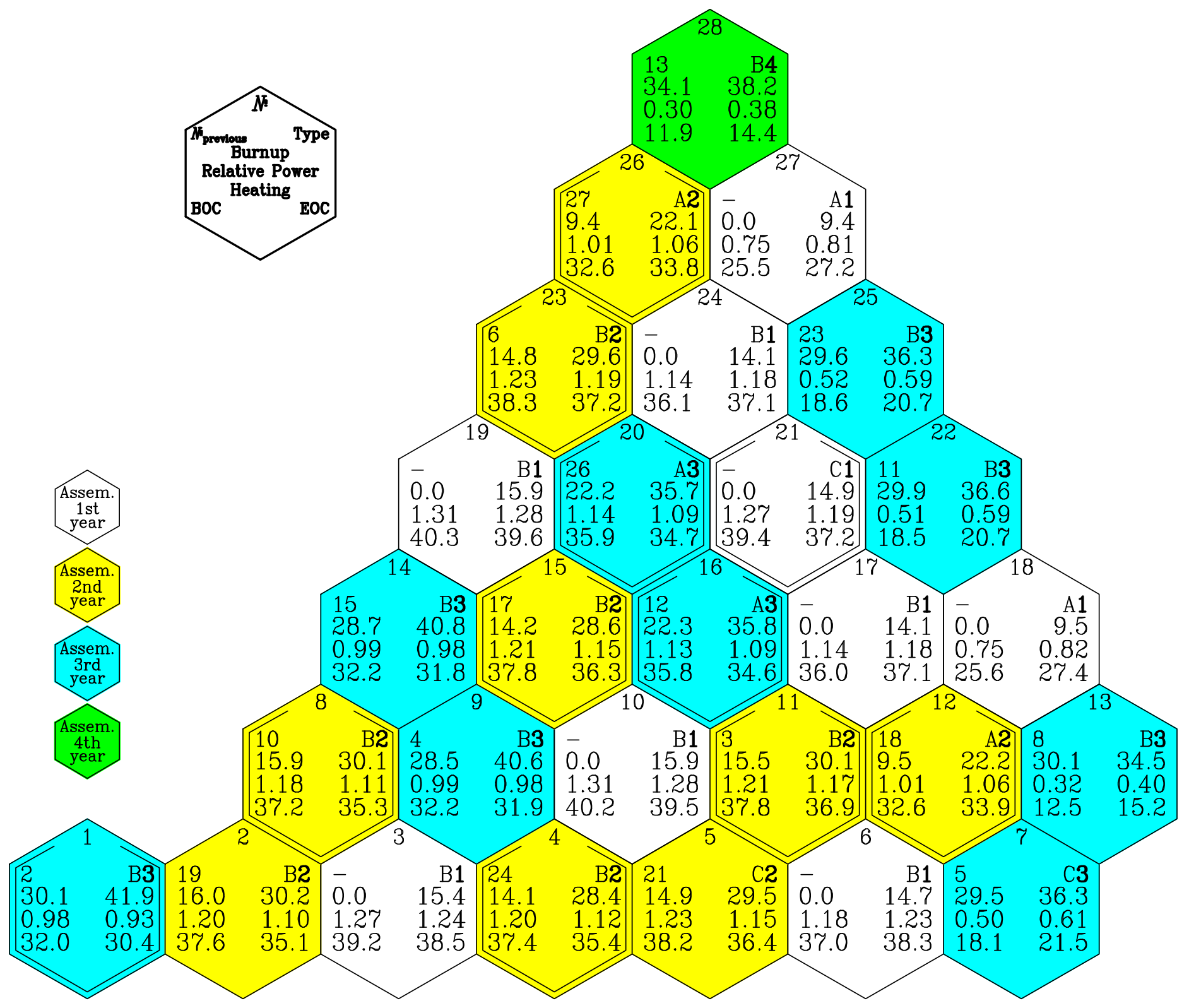


Fig.9. Assembly-by-Assembly Maximum Linear Pin Power Distribution in BOC. Equilibrium Cycle for Uranium Reference Core with Boron BPRs.Core $60^{\circ}$ Sector

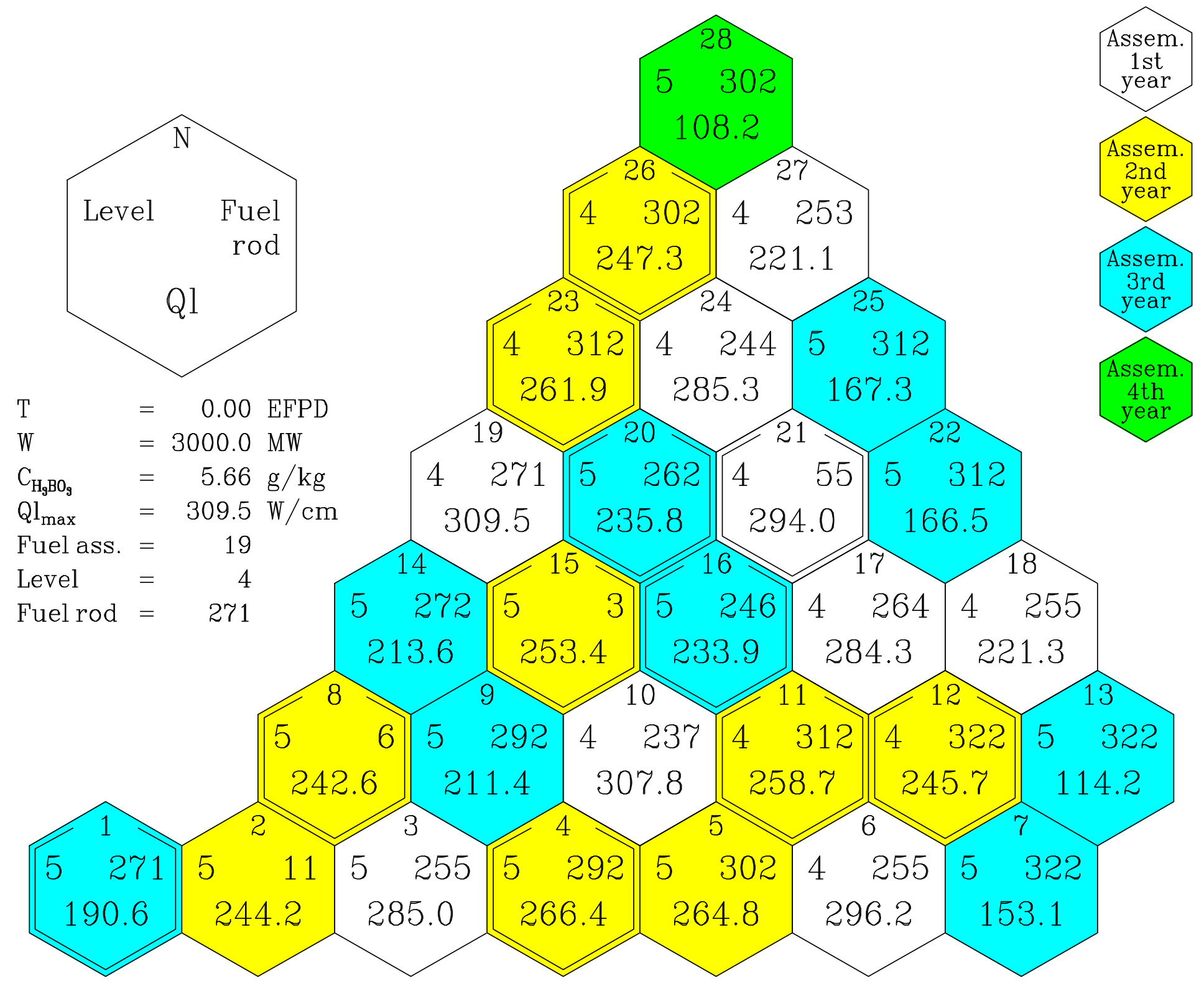


Fig.10. Assembly-by-Assembly Maximum Linear Pin Power Distribution in EOC. Equilibrium Cycle for Uranium Reference Core with Boron BPRs.Core $60^{\circ}$ Sector

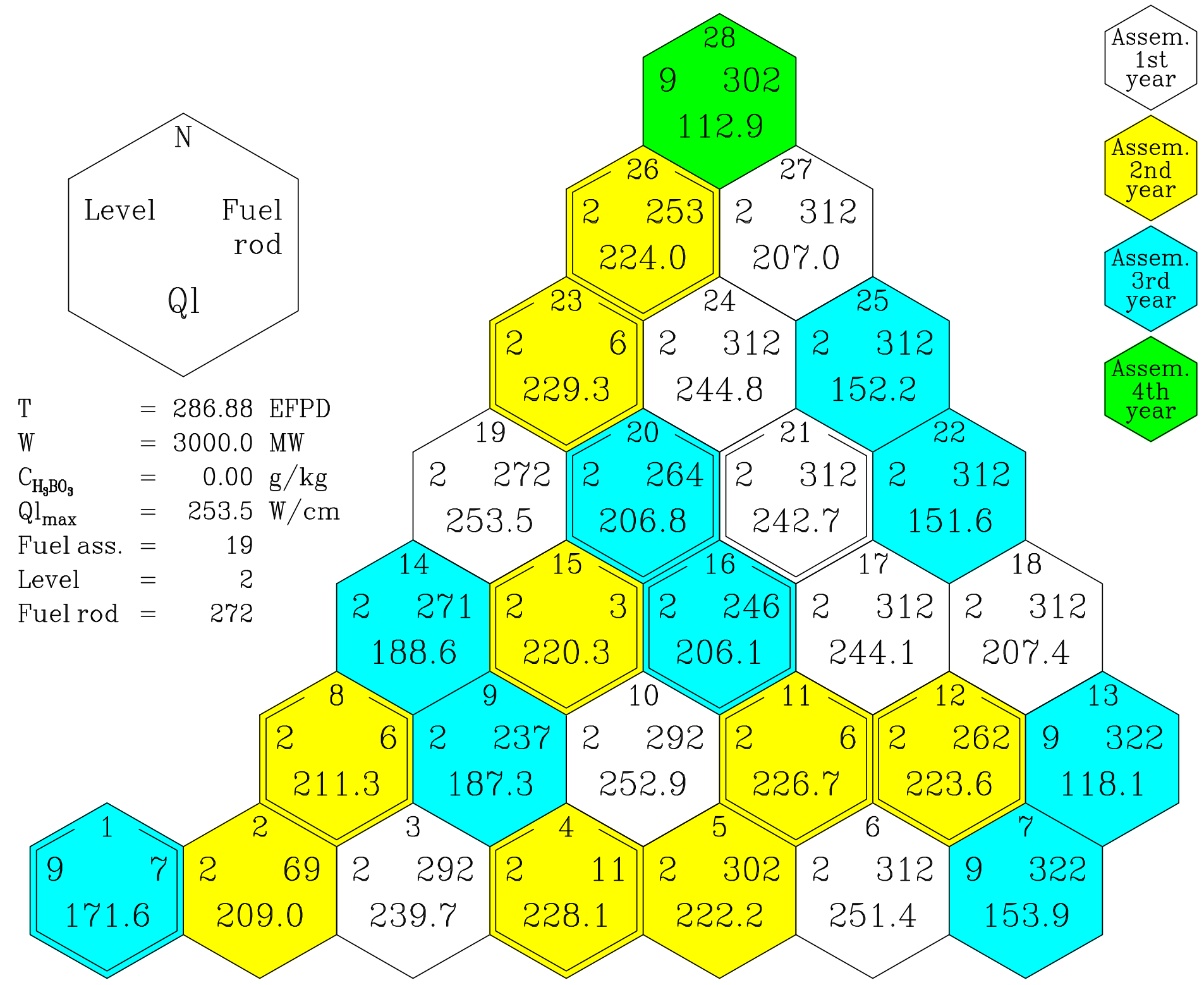


RUSSIAN RESEARCH CENTER KURCHATOV INSTITUTE

Kinetics Parameters of VVER-1000 Core with 3 MOX Lead Test Assemblies to be used for Accident Analysis Codes

Fig.11. Pin-by-Pin Power Distribution in the Most Powered Assembly in BOC. Equilibrium Cycle for Uranium Reference Core with Boron BPRs

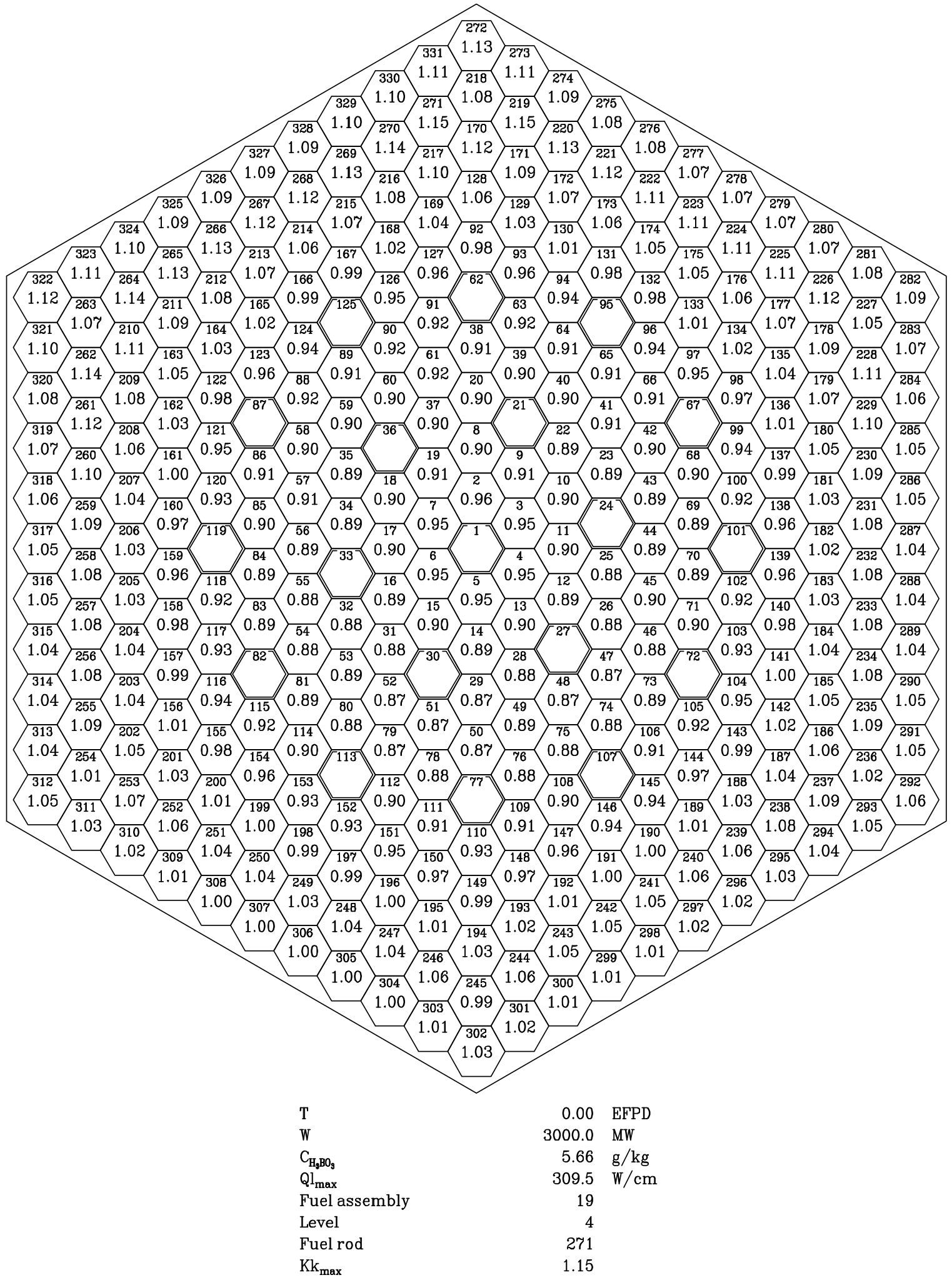


RUSSIAN RESEARCH CENTER KURCHATOV INSTITUTE

Kinetics Parameters of VVER-1000 Core with 3 MOX Lead Test Assemblies to be used for Accident Analysis Codes

Fig.12. Pin-by-Pin Power Distribution in the Most Powered Assembly in EOC. Equilibrium Cycle for Uranium Reference Core with Boron BPRs

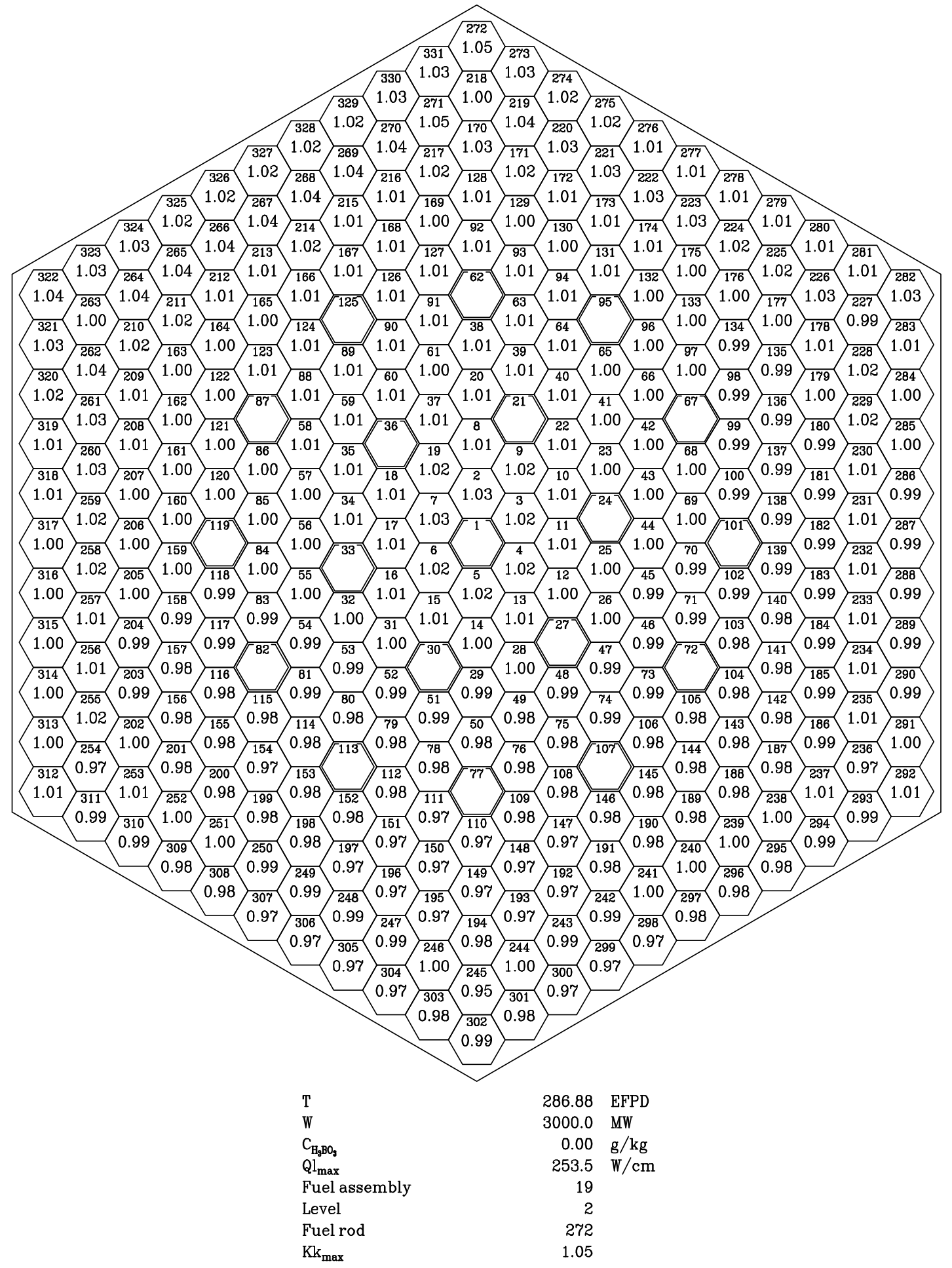


Fig.13. Control Rods Grouping

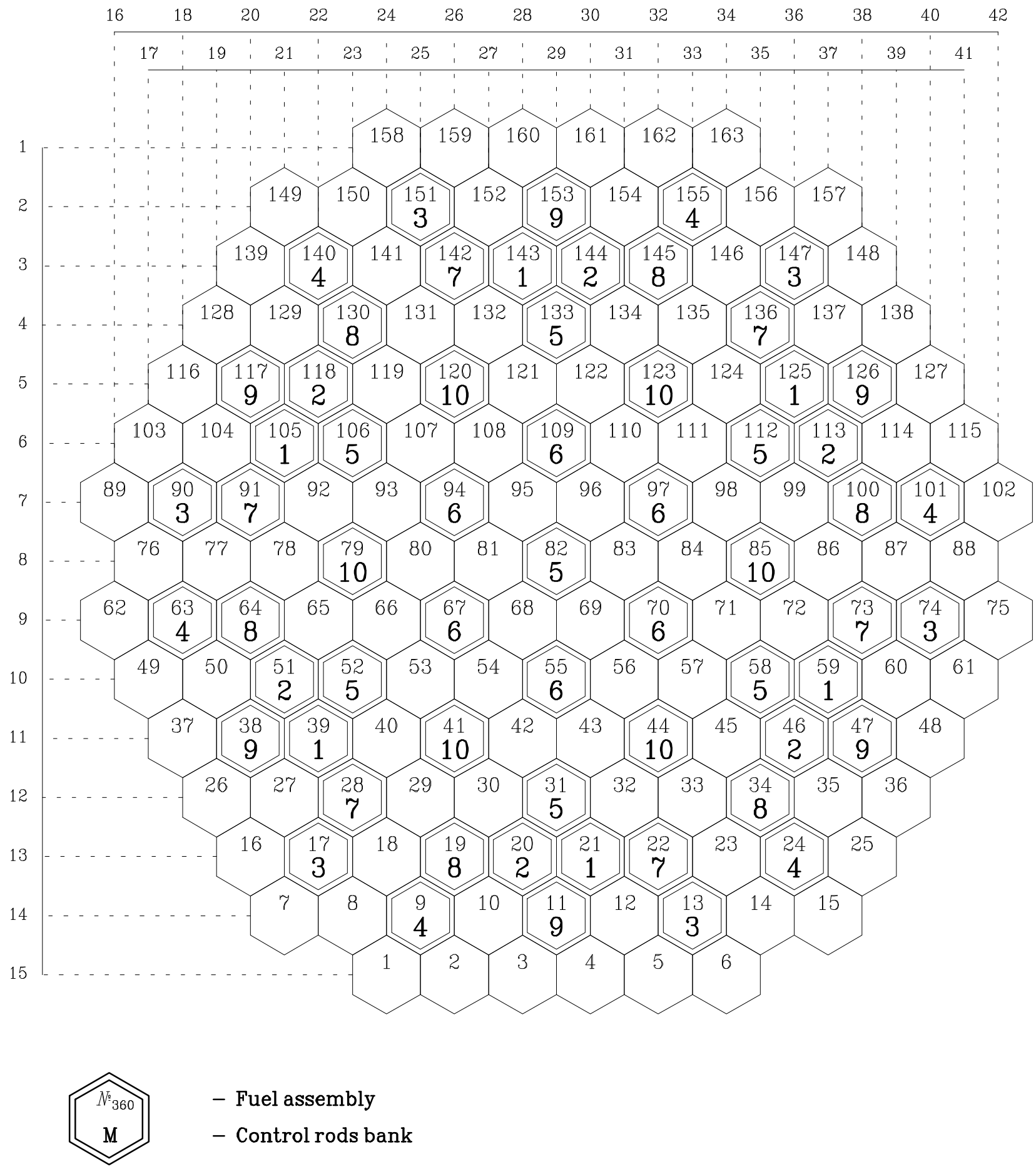


Fig.14. Reloading Scheme. First Cycle with 3 MOX LTAs

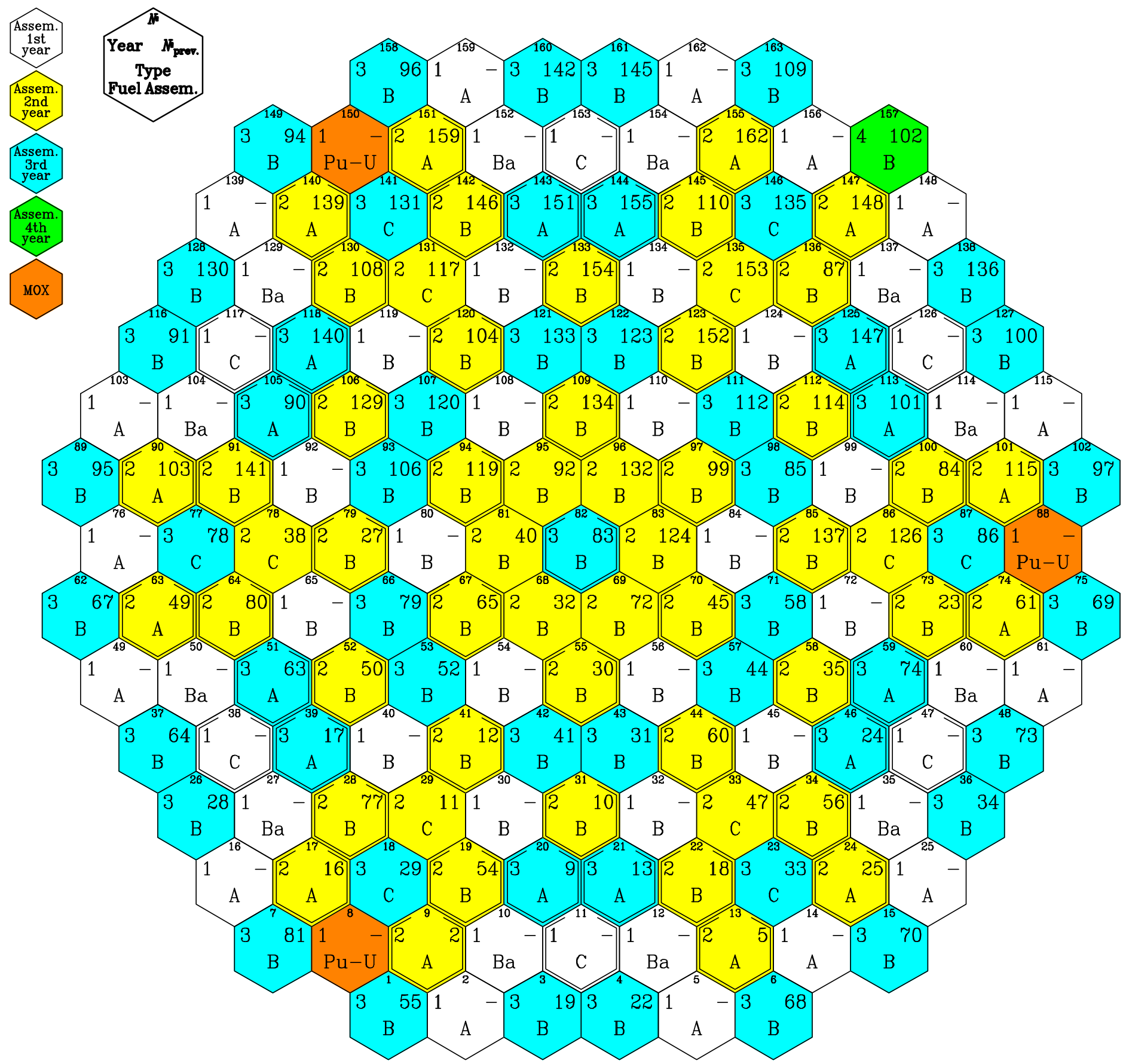


RUSSIAN RESEARCH CENTER KURCHATOV INSTITUTE

Kinetics Parameters of VVER-1000 Core with 3 MOX Lead Test Assemblies to be used for

Accident Analysis Codes

Fig.15. Assembly-by-Assembly Power Distribution.

First Cycle with 3 MOX LTAs $100 \%$ Pu (4.2-3.0-2.0)

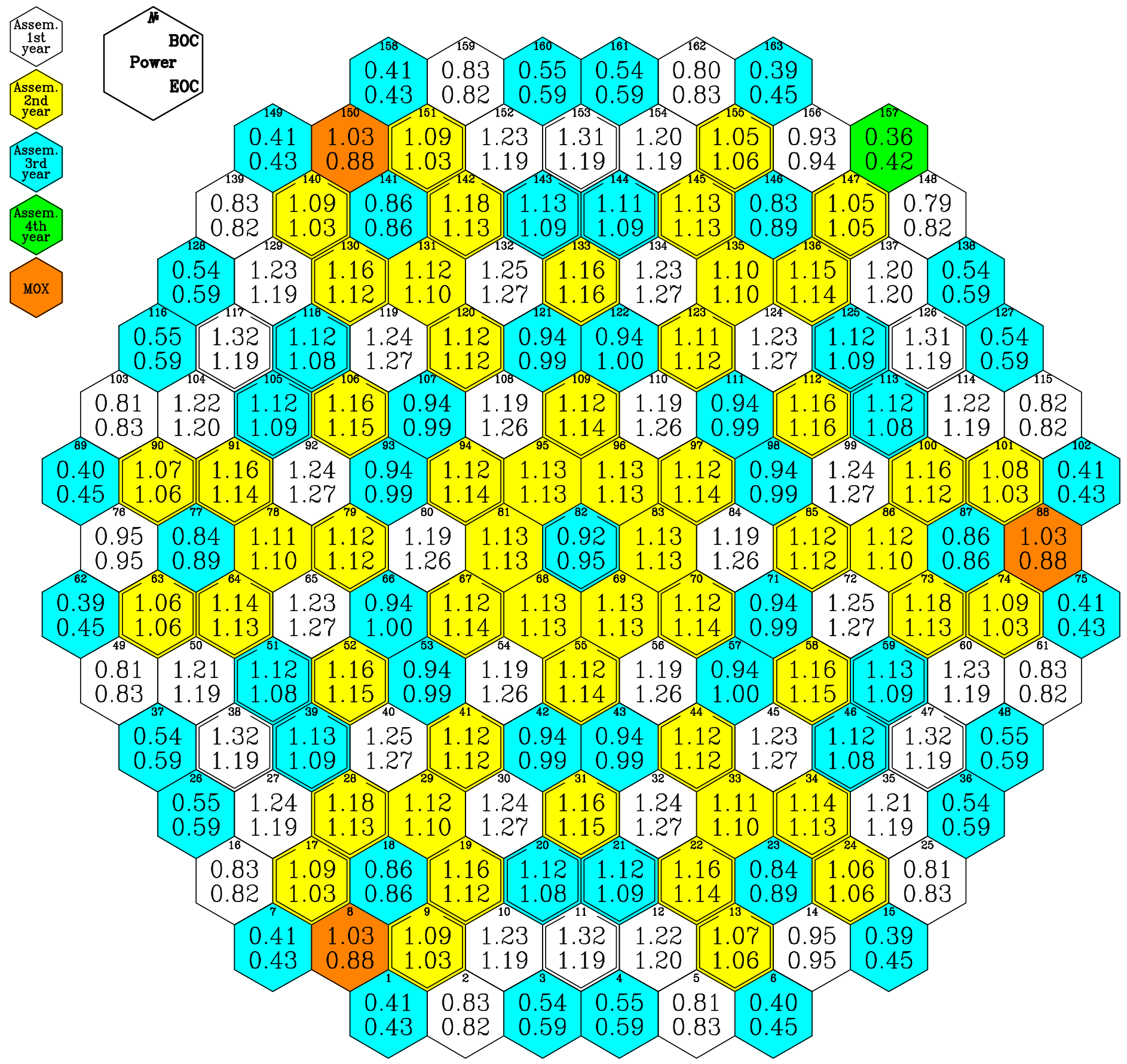


RUSSIAN RESEARCH CENTER KURCHATOV INSTITUTE

Kinetics Parameters of VVER-1000 Core with 3 MOX Lead Test Assemblies to be used for Accident Analysis Codes

Fig.16. Assembly-by-Assembly Burnup Distribution.

First Cycle with 3 MOX LTAs 100\%Pu (4.2-3.0-2.0)

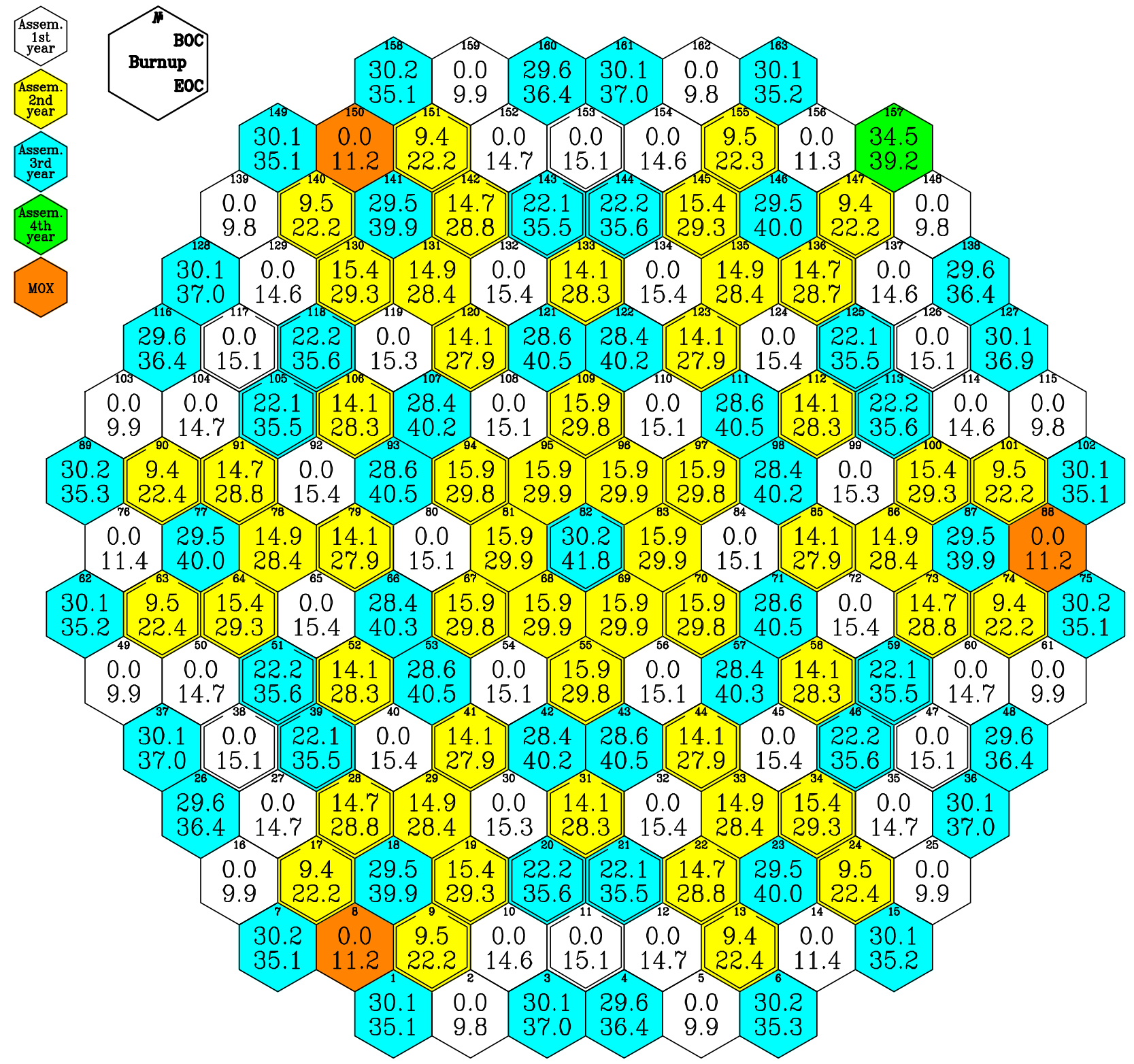


RUSSIAN RESEARCH CENTER KURCHATOV INSTITUTE

Kinetics Parameters of VVER-1000 Core with 3 MOX Lead Test Assemblies to be used for

Accident Analysis Codes

Fig.17. Assembly-by-Assembly Temperature Drop Distribution.

First Cycle with 3 MOX LTAs 100\%Pu (4.2-3.0-2.0)

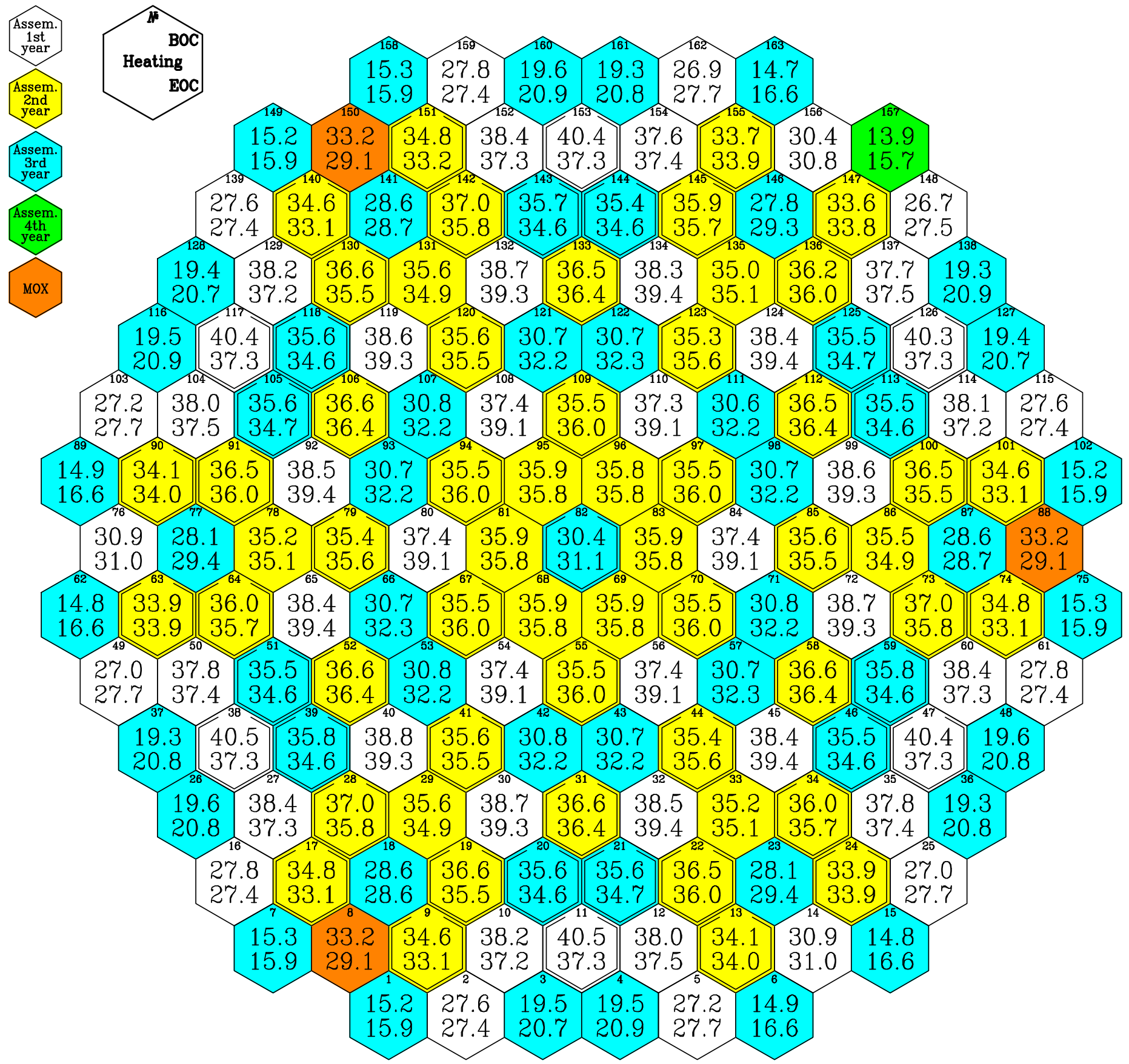


RUSSIAN RESEARCH CENTER KURCHATOV INSTITUTE

Kinetics Parameters of VVER-1000 Core with 3 MOX Lead Test Assemblies to be used for Accident Analysis Codes

Fig.18. Assembly-by-Assembly Maximum Linear Pin Power Distribution in BOC. First Cycle with 3 MOX LTAs 100\%Pu (4.2-3.0-2.0)

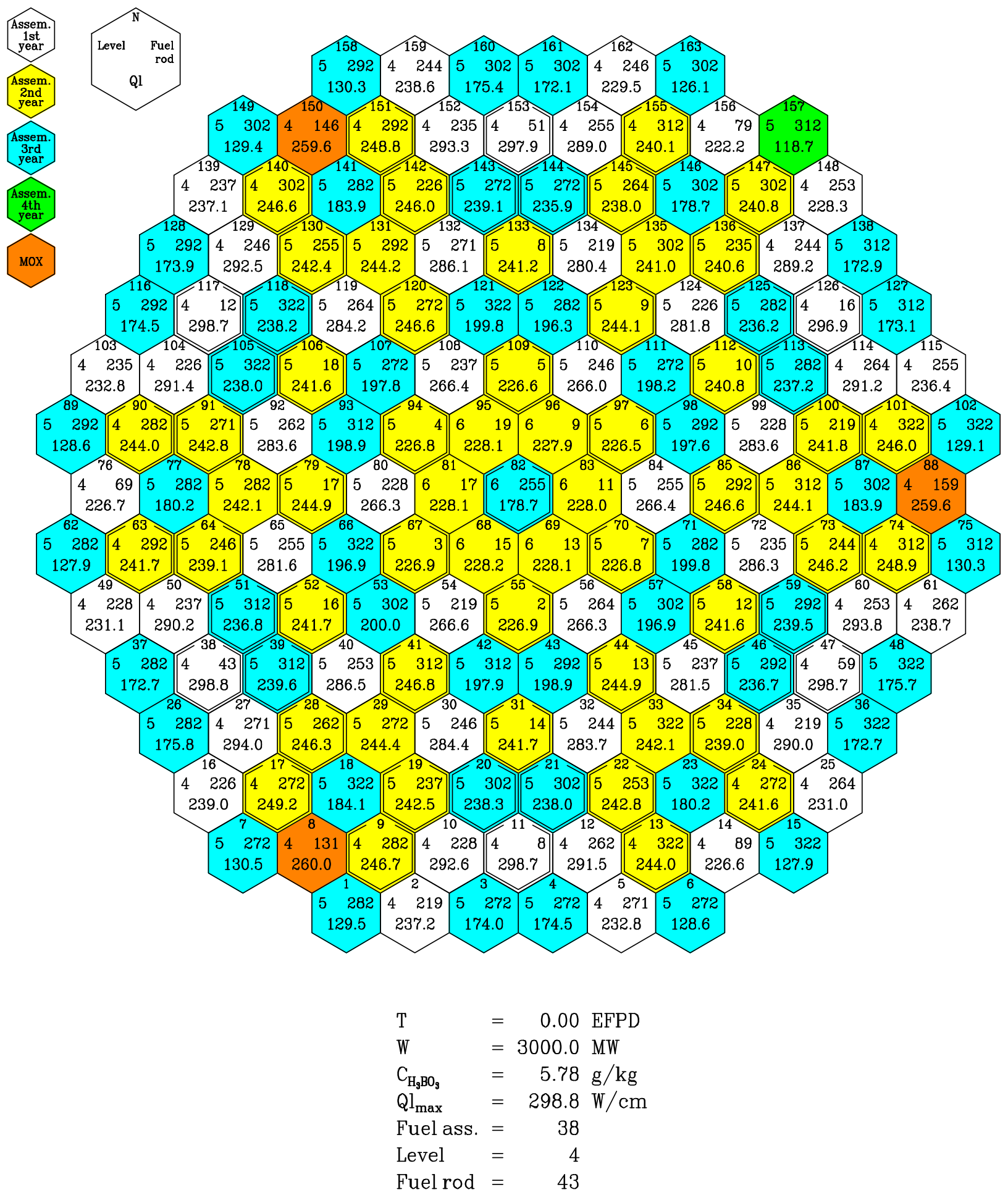


RUSSIAN RESEARCH CENTER KURCHATOV INSTITUTE

Kinetics Parameters of VVER-1000 Core with 3 MOX Lead Test Assemblies to be used for Accident Analysis Codes

Fig.19. Assembly-by-Assembly Maximum Linear Pin Power Distribution in EOC. First Cycle with 3 MOX LTAs $100 \%$ Pu (4.2-3.0-2.0)

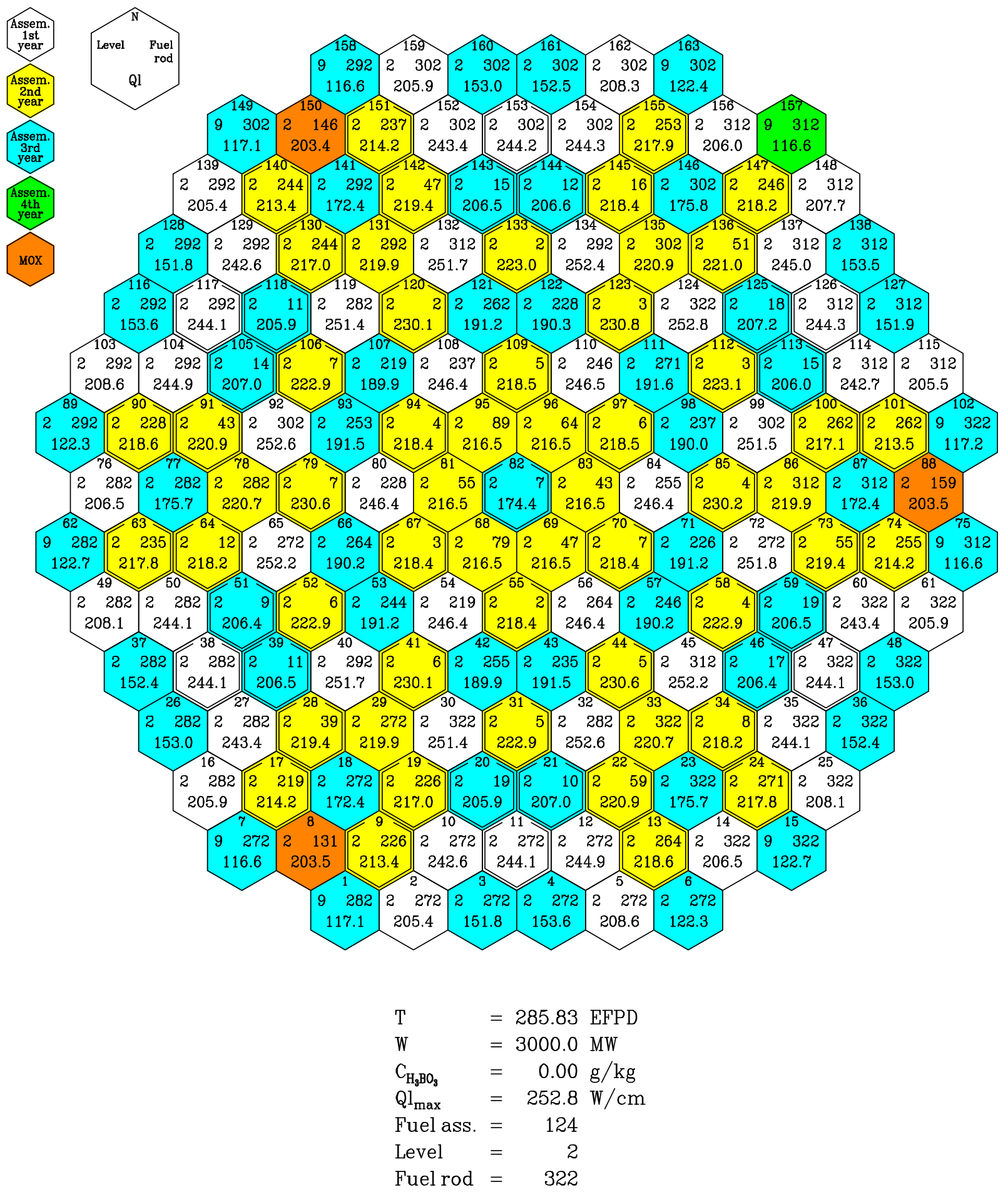


RUSSIAN RESEARCH CENTER KURCHATOV INSTITUTE

Kinetics Parameters of VVER-1000 Core with 3 MOX Lead Test Assemblies to be used for Accident Analysis Codes

Fig.20. Pin-by-Pin Power Distribution in the Most Powered Assembly in BOC.

First Cycle with 3 MOX LTAs 100\% Pu (4.2-3.0-2.0)

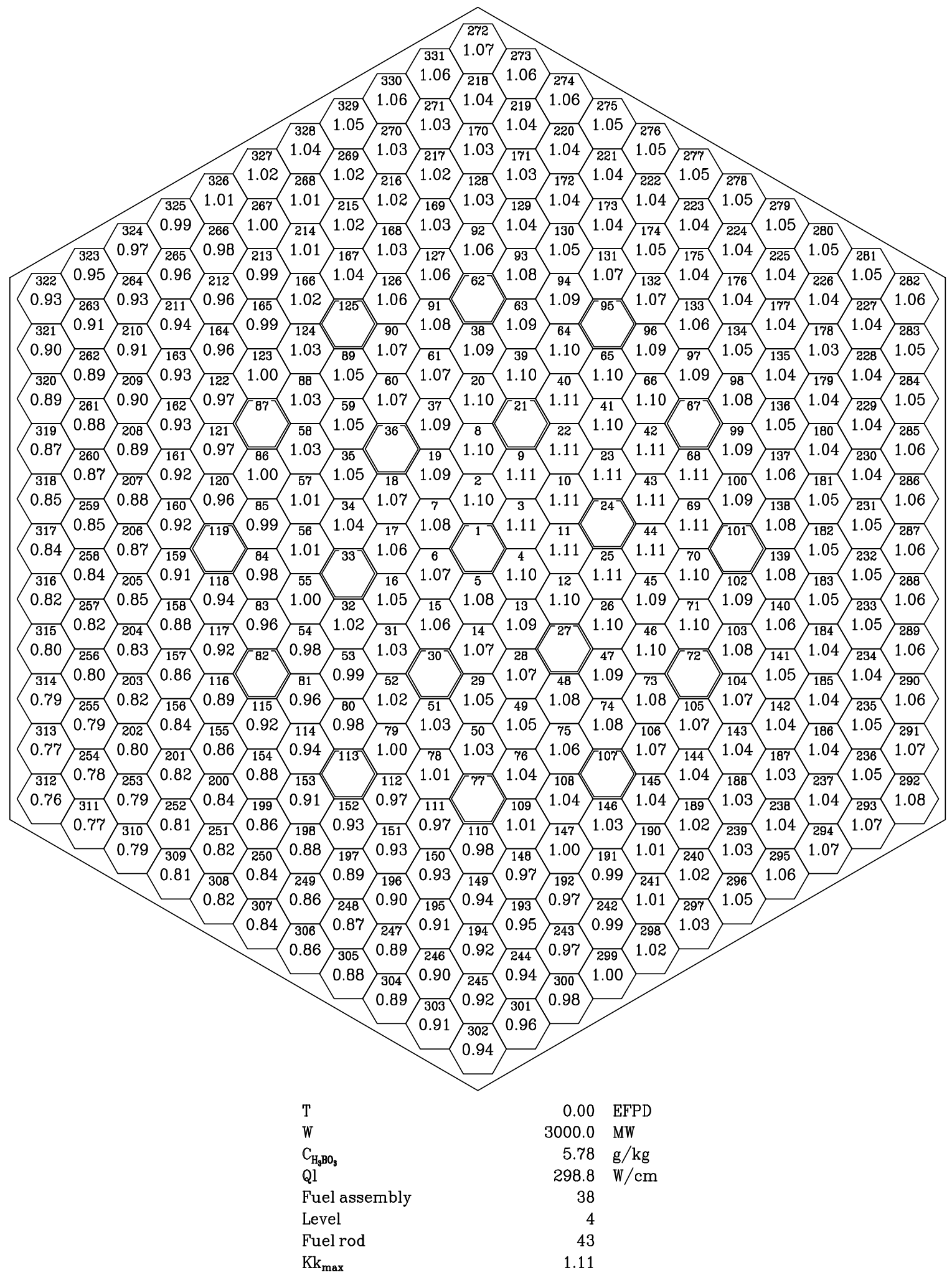


RUSSIAN RESEARCH CENTER KURCHATOV INSTITUTE

Kinetics Parameters of VVER-1000 Core with 3 MOX Lead Test Assemblies to be used for Accident Analysis Codes

Fig.21. Pin-by-Pin Power Distribution in the Most Powered Assembly in EOC. First Cycle with 3 MOX LTAs 100\%Pu (4.2-3.0-2.0)

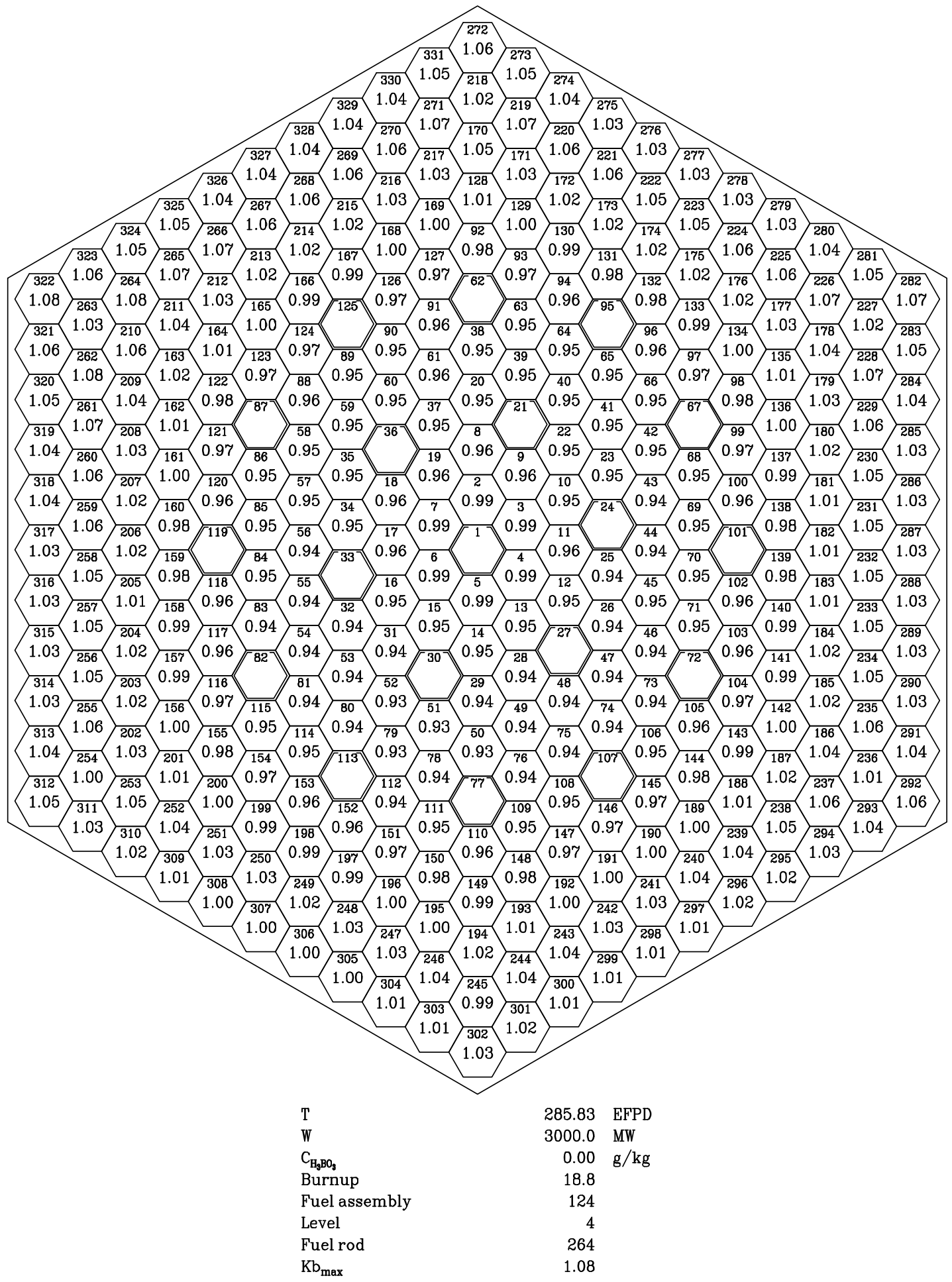


RUSSIAN RESEARCH CENTER KURCHATOV INSTITUTE

Kinetics Parameters of VVER-1000 Core with 3 MOX Lead Test Assemblies to be used for Accident Analysis Codes

Fig.22. Pin-by-Pin Power Distribution in MOX LTA in BOC. First Cycle with 3 MOX LTAs $100 \%$ Pu (4.2-3.0-2.0)

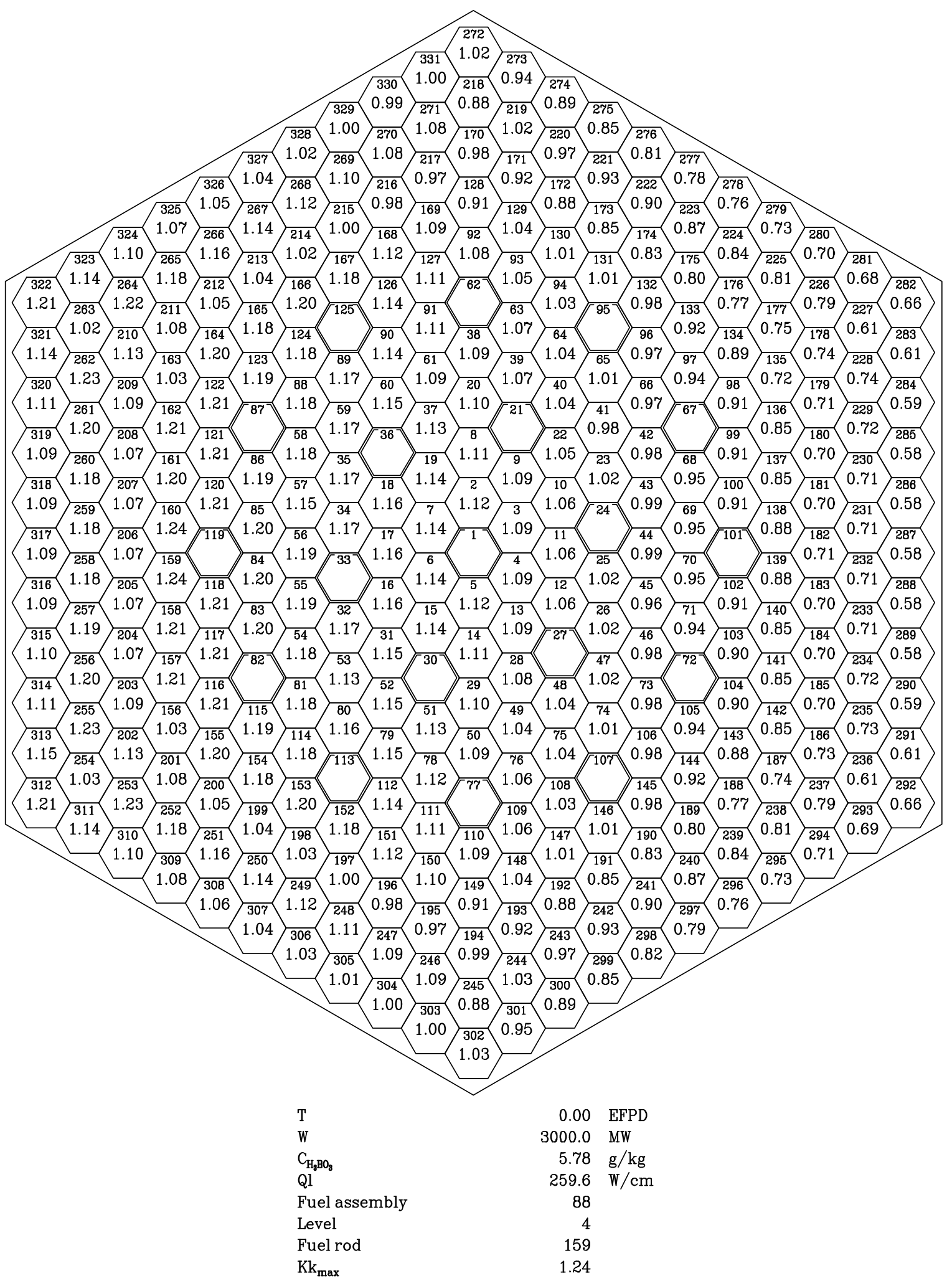


RUSSIAN RESEARCH CENTER KURCHATOV INSTITUTE

Kinetics Parameters of VVER-1000 Core with 3 MOX Lead Test Assemblies to be used for Accident Analysis Codes

Fig.23. Pin-by-Pin Power Distribution in MOX LTA in EOC. First Cycle with 3 MOX LTAs $100 \%$ Pu (4.2-3.0-2.0)

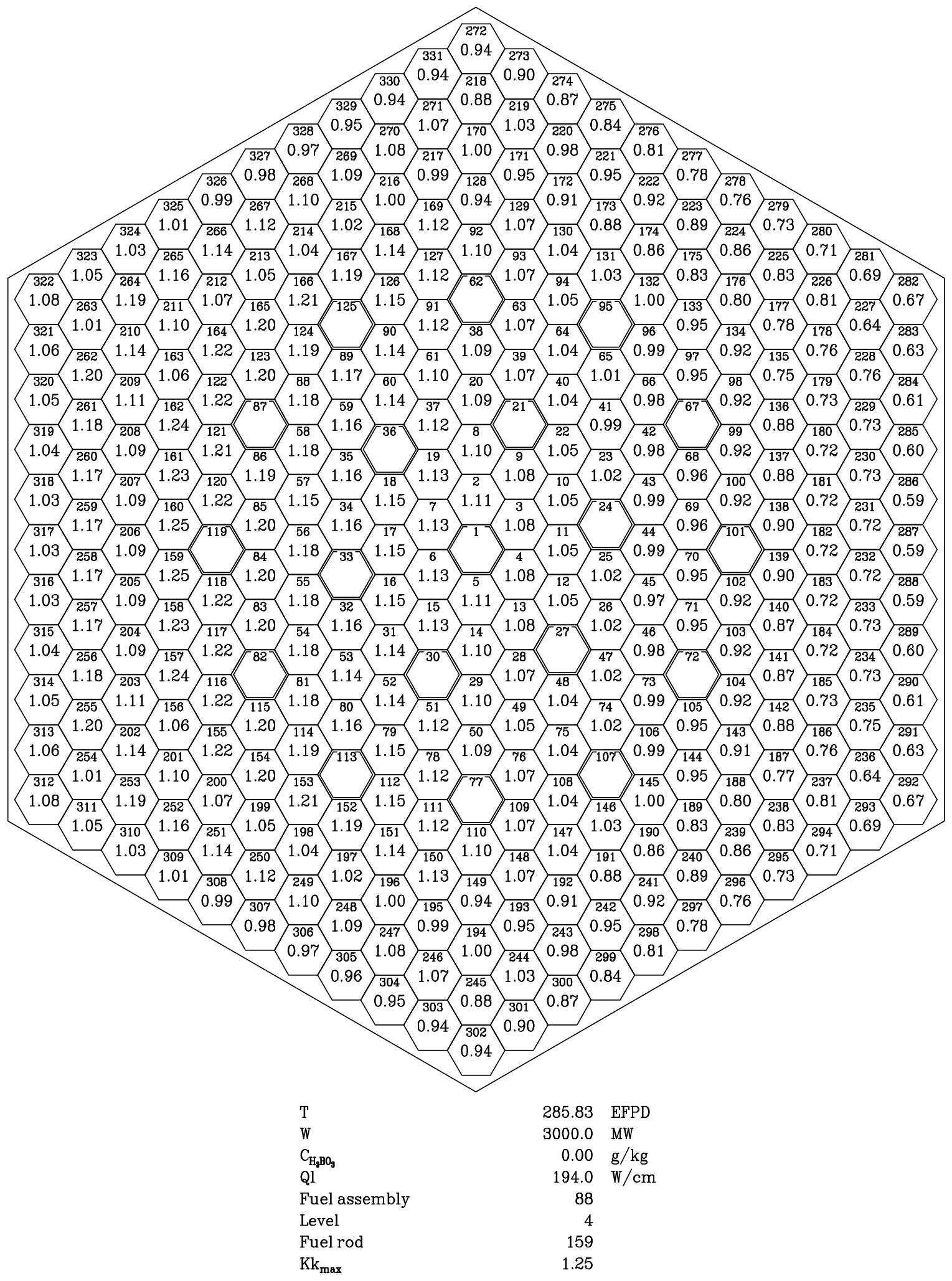


RUSSIAN RESEARCH CENTER KURCHATOV INSTITUTE

Kinetics Parameters of VVER-1000 Core with 3 MOX Lead Test Assemblies to be used for

Accident Analysis Codes

Fig.24. Assembly-by-Assembly Power Distribution.

First Cycle with 3 MOX LTAs of "Island" Type (Pu3.8-2.8, U-3.7)

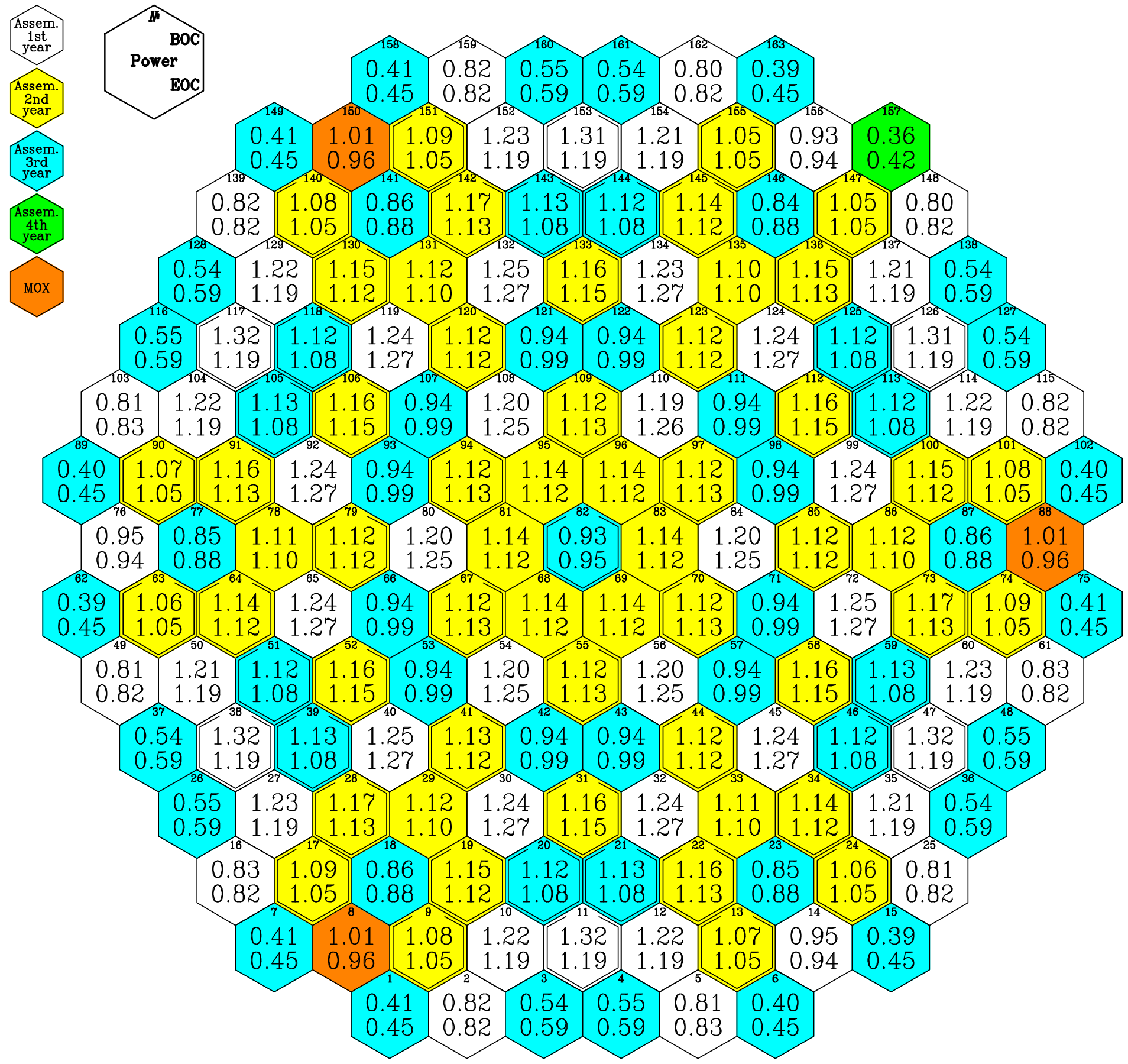


RUSSIAN RESEARCH CENTER KURCHATOV INSTITUTE

Kinetics Parameters of VVER-1000 Core with 3 MOX Lead Test Assemblies to be used for

Accident Analysis Codes

Fig.25. Assembly-by-Assembly Burnup Distribution.

First Cycle with 3 MOX LTAs of "Island" Type (Pu3.8-2.8, U-3.7)

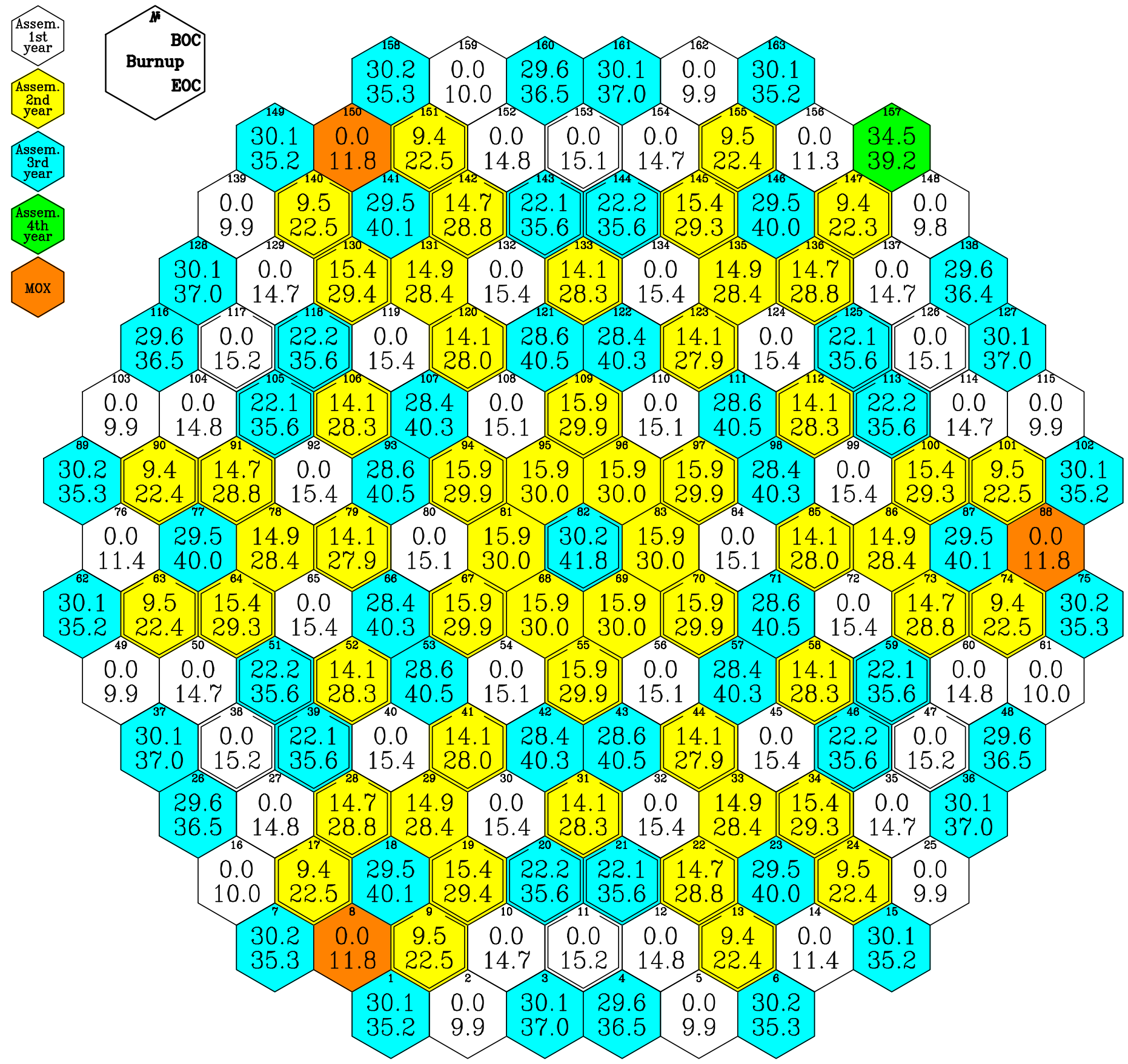


RUSSIAN RESEARCH CENTER KURCHATOV INSTITUTE

Kinetics Parameters of VVER-1000 Core with 3 MOX Lead Test Assemblies to be used for

Accident Analysis Codes

Fig.26. Assembly-by-Assembly Temperature Drop Distribution.

First Cycle with 3 MOX LTAs of "Island" Type (Pu3.8-2.8, U-3.7)

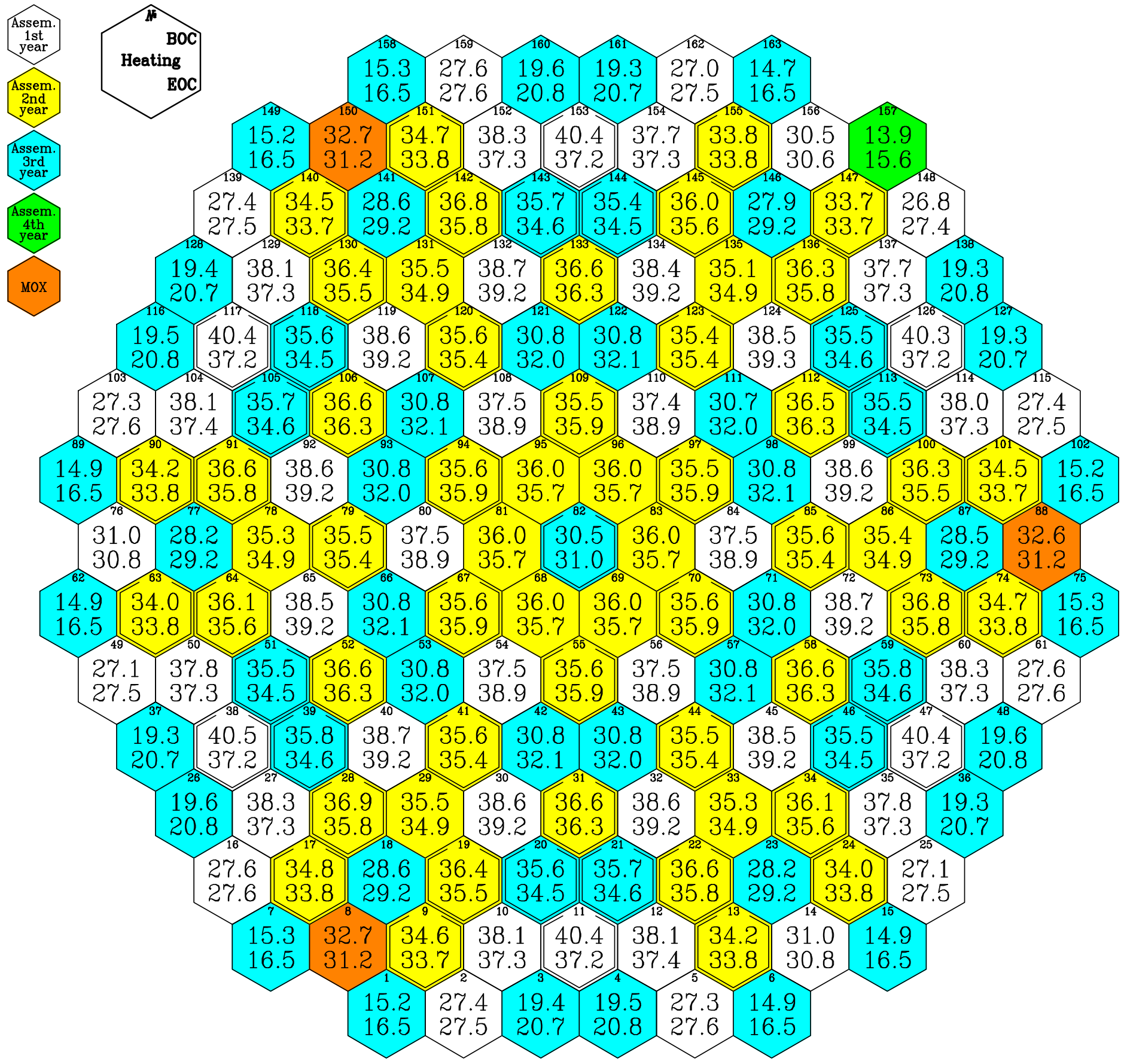


RUSSIAN RESEARCH CENTER KURCHATOV INSTITUTE

Kinetics Parameters of VVER-1000 Core with 3 MOX Lead Test Assemblies to be used for Accident Analysis Codes

Fig.27. Assembly-by-Assembly Maximum Linear Power Distribution in BOC. First Cycle with 3 MOX LTAs of "Island" Type (Pu3.8-2.8-U3.7)

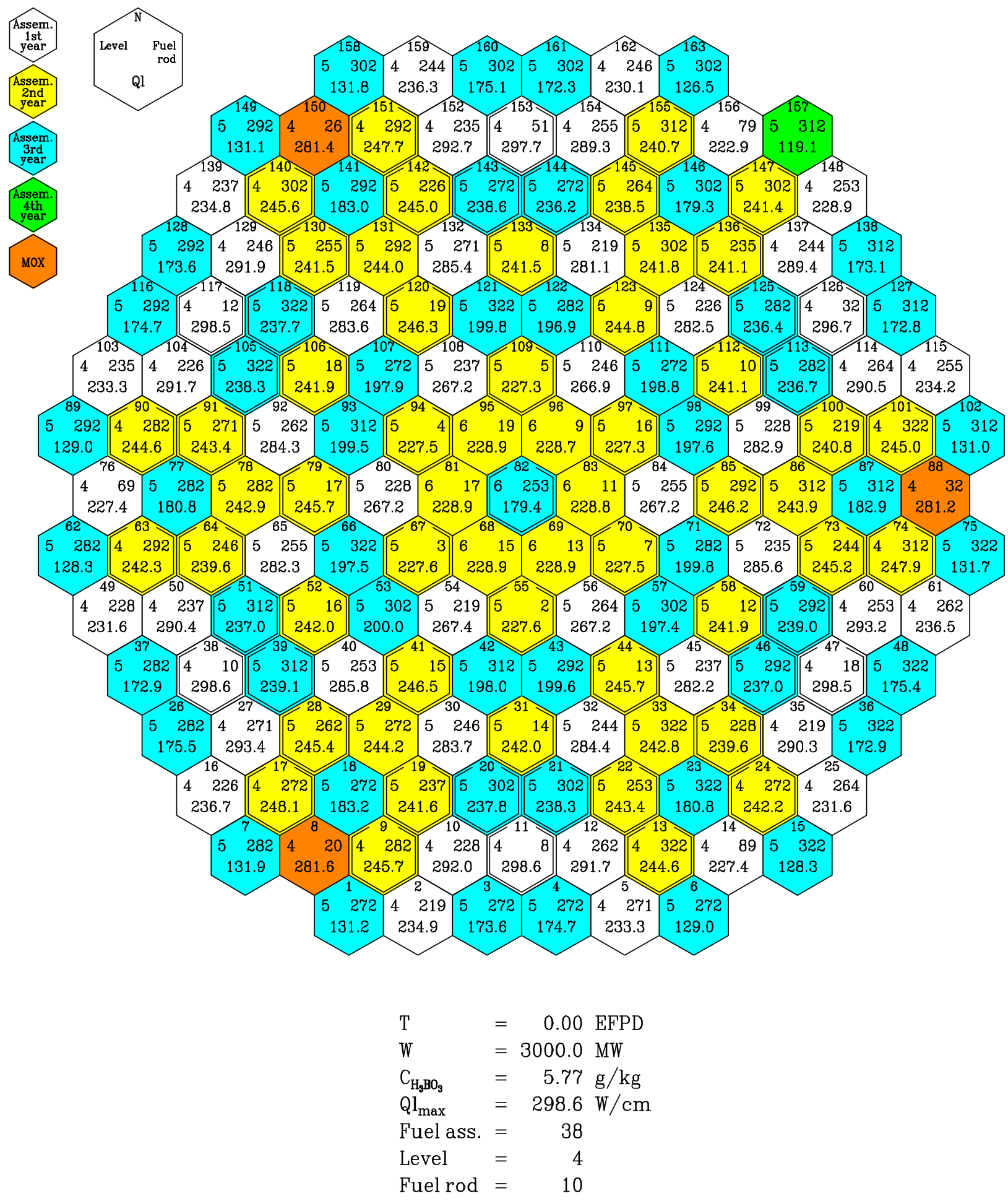


RUSSIAN RESEARCH CENTER KURCHATOV INSTITUTE

Kinetics Parameters of VVER-1000 Core with 3 MOX Lead Test Assemblies to be used for Accident Analysis Codes

Fig.28. Assembly-by-Assembly Maximum Linear Power Distribution in EOC. First Cycle with 3 MOX LTAs of "Island" Type (Pu3.8-2.8-U3.7)

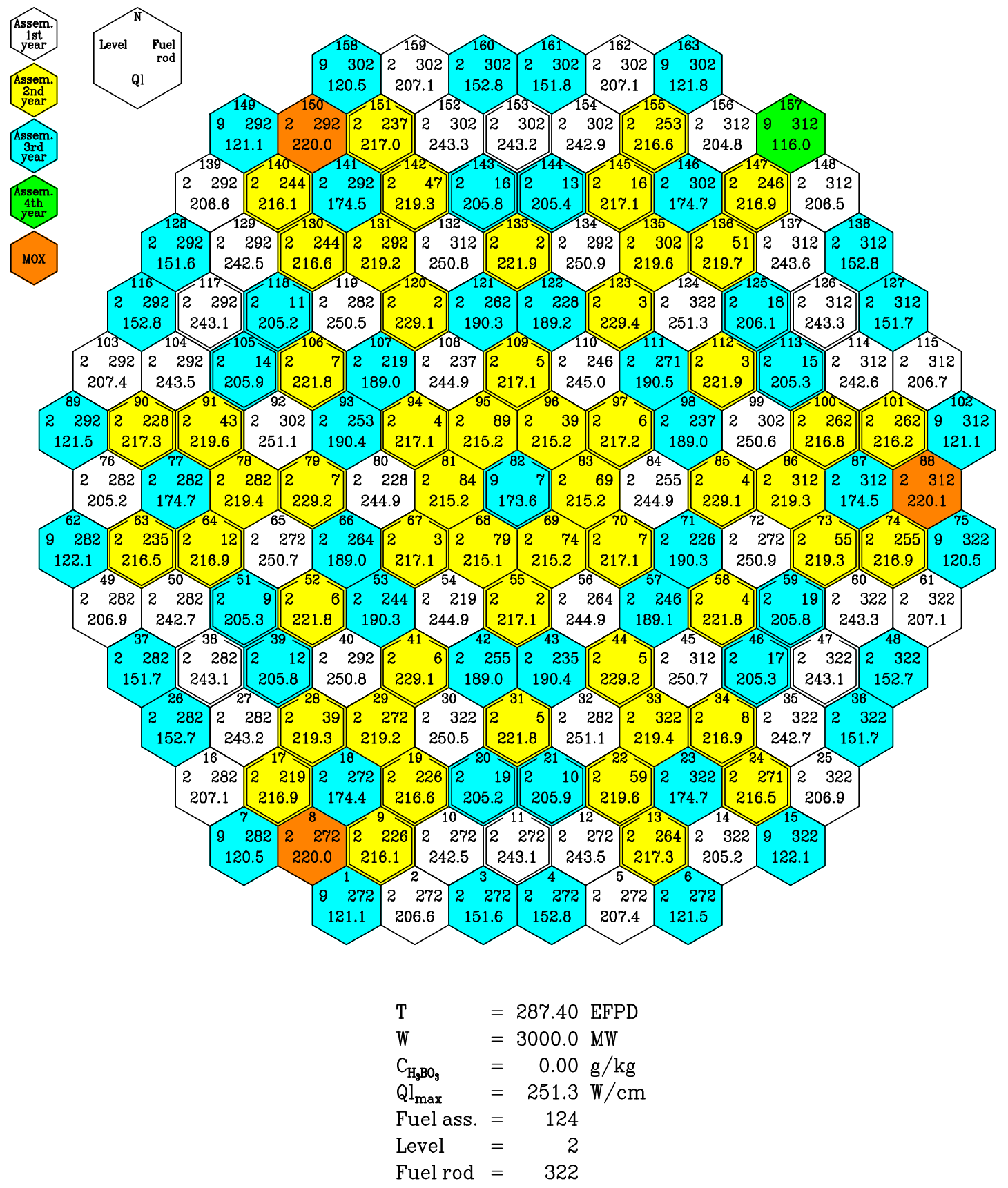


RUSSIAN RESEARCH CENTER KURCHATOV INSTITUTE

Kinetics Parameters of VVER-1000 Core with 3 MOX Lead Test Assemblies to be used for Accident Analysis Codes

Fig.29. Pin-by-Pin Power Distribution in the Most Powered Assembly in BOC. First Cycle with 3 MOX LTAs of "Island" Type (Pu3.8-2.8, U-3.7

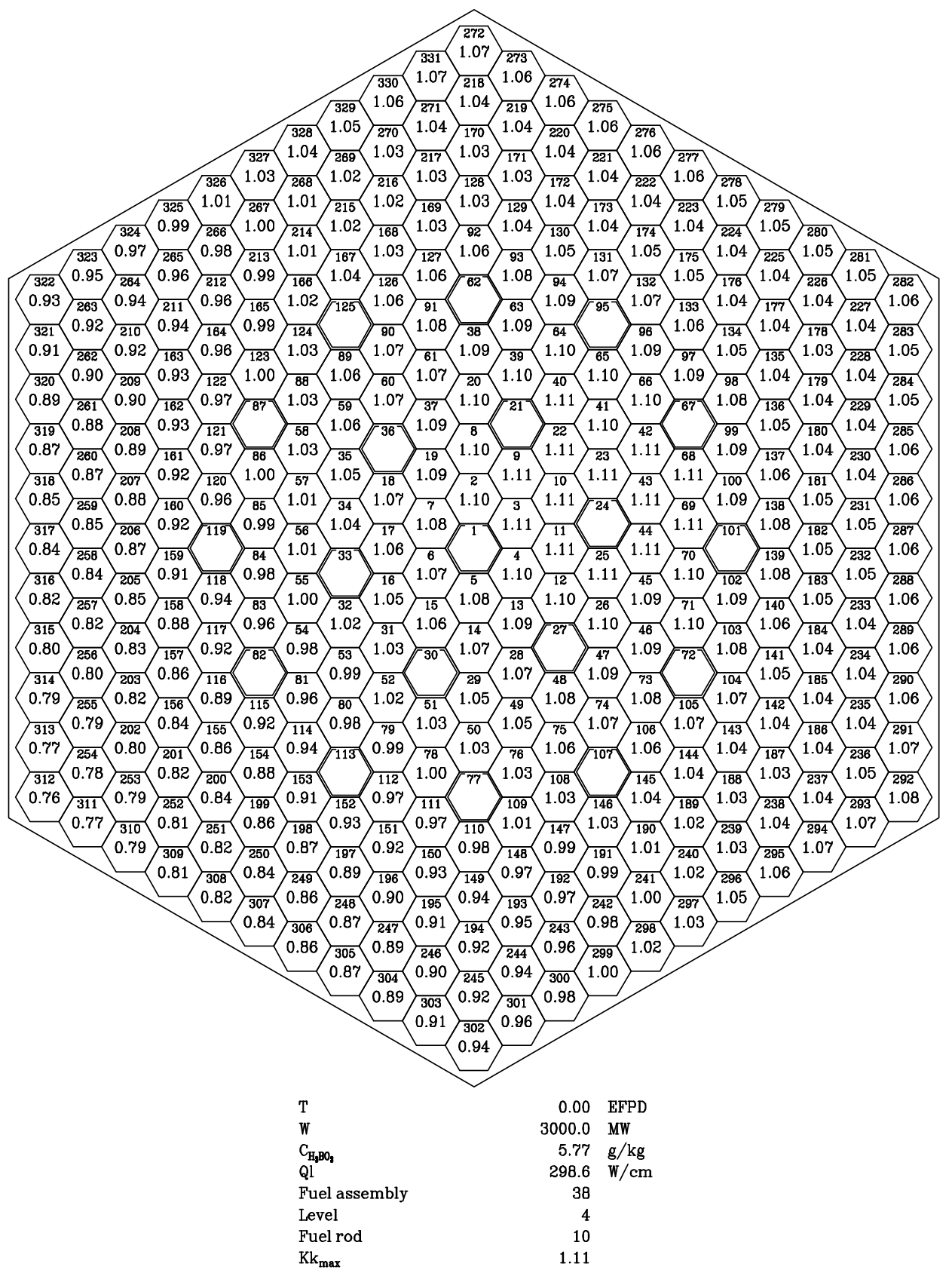


RUSSIAN RESEARCH CENTER KURCHATOV INSTITUTE

Kinetics Parameters of VVER-1000 Core with 3 MOX Lead Test Assemblies to be used for Accident Analysis Codes

Fig.30. Pin-by-Pin Power Distribution in the Most Powered Assembly in EOC. First Cycle with 3 MOX LTAs of "Island" Type (Pu3.8-2.8, U-3.7)

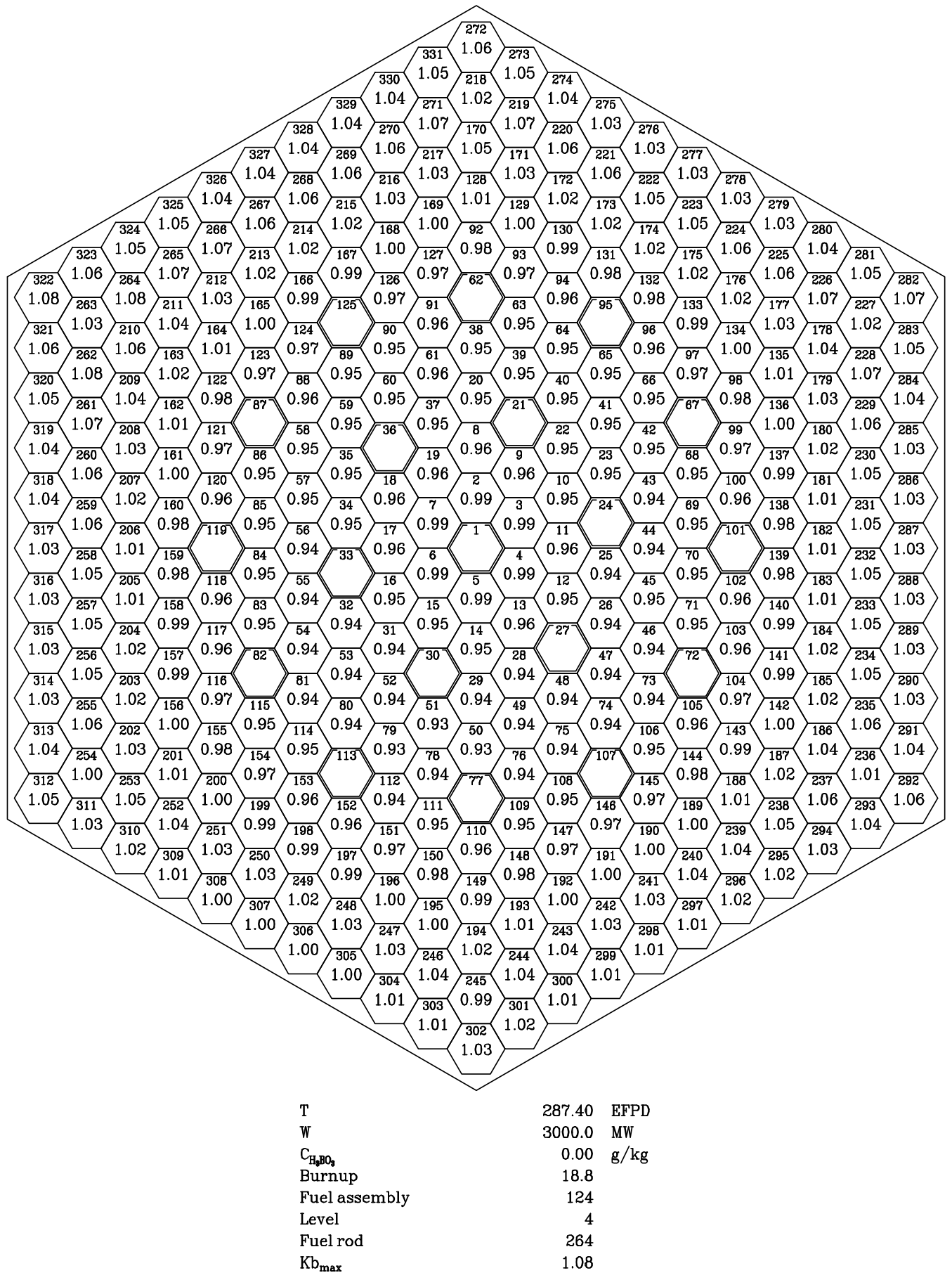


RUSSIAN RESEARCH CENTER KURCHATOV INSTITUTE

Kinetics Parameters of VVER-1000 Core with 3 MOX Lead Test Assemblies to be used for Accident Analysis Codes

Fig.31. Pin-by-Pin Power Distribution in MOX LTA in BOC. First Cycle with 3 MOX LTAs of "Island" Type (Pu3.8-2.8, U-3.7)

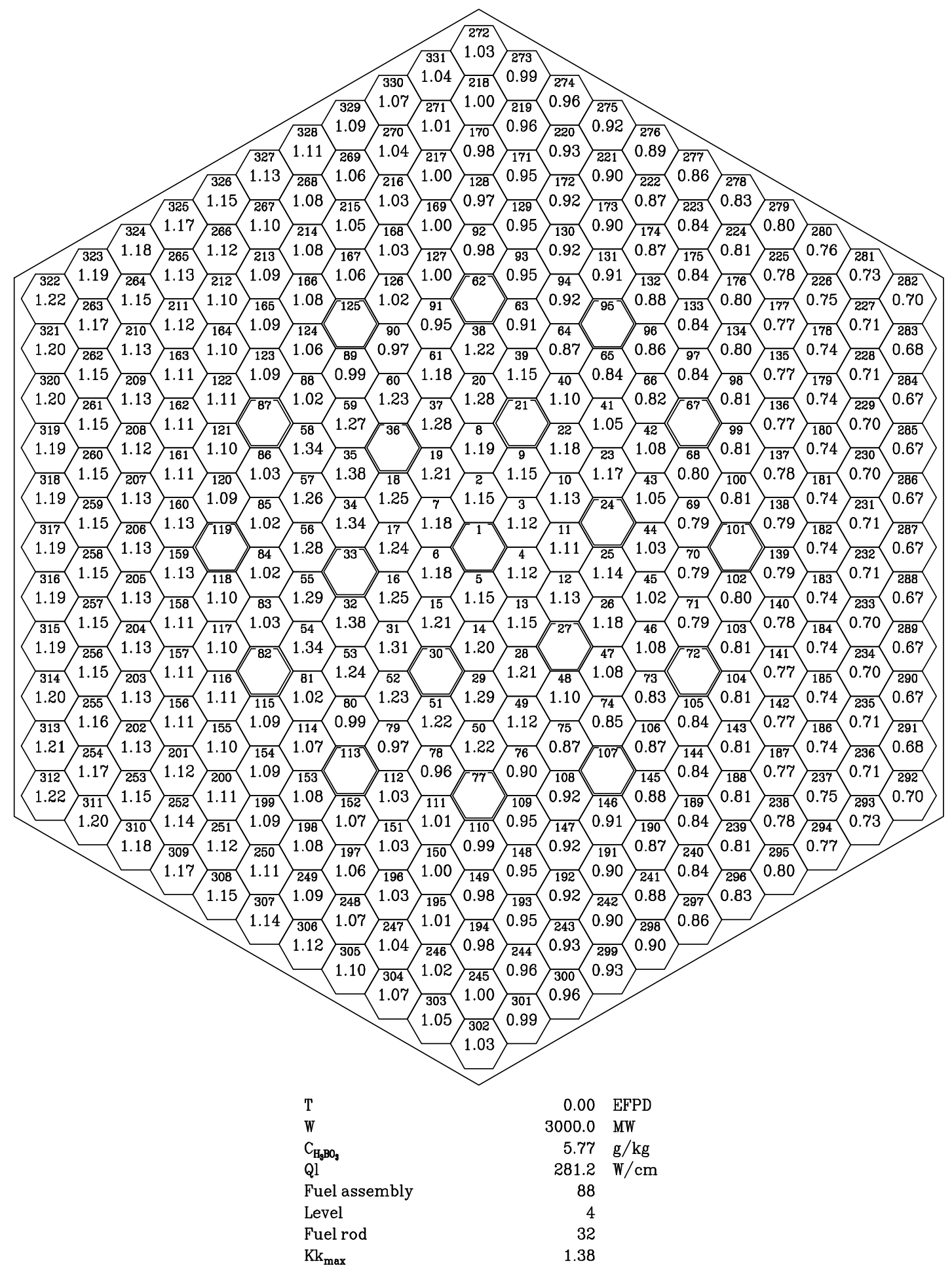


RUSSIAN RESEARCH CENTER KURCHATOV INSTITUTE

Kinetics Parameters of VVER-1000 Core with 3 MOX Lead Test Assemblies to be used for Accident Analysis Codes

Fig.32. Pin-by-Pin Power Distribution in MOX LTA in EOC. First Cycle with 3 MOX LTAs of "Island" Type (Pu3.8-2.8, U-3.7)

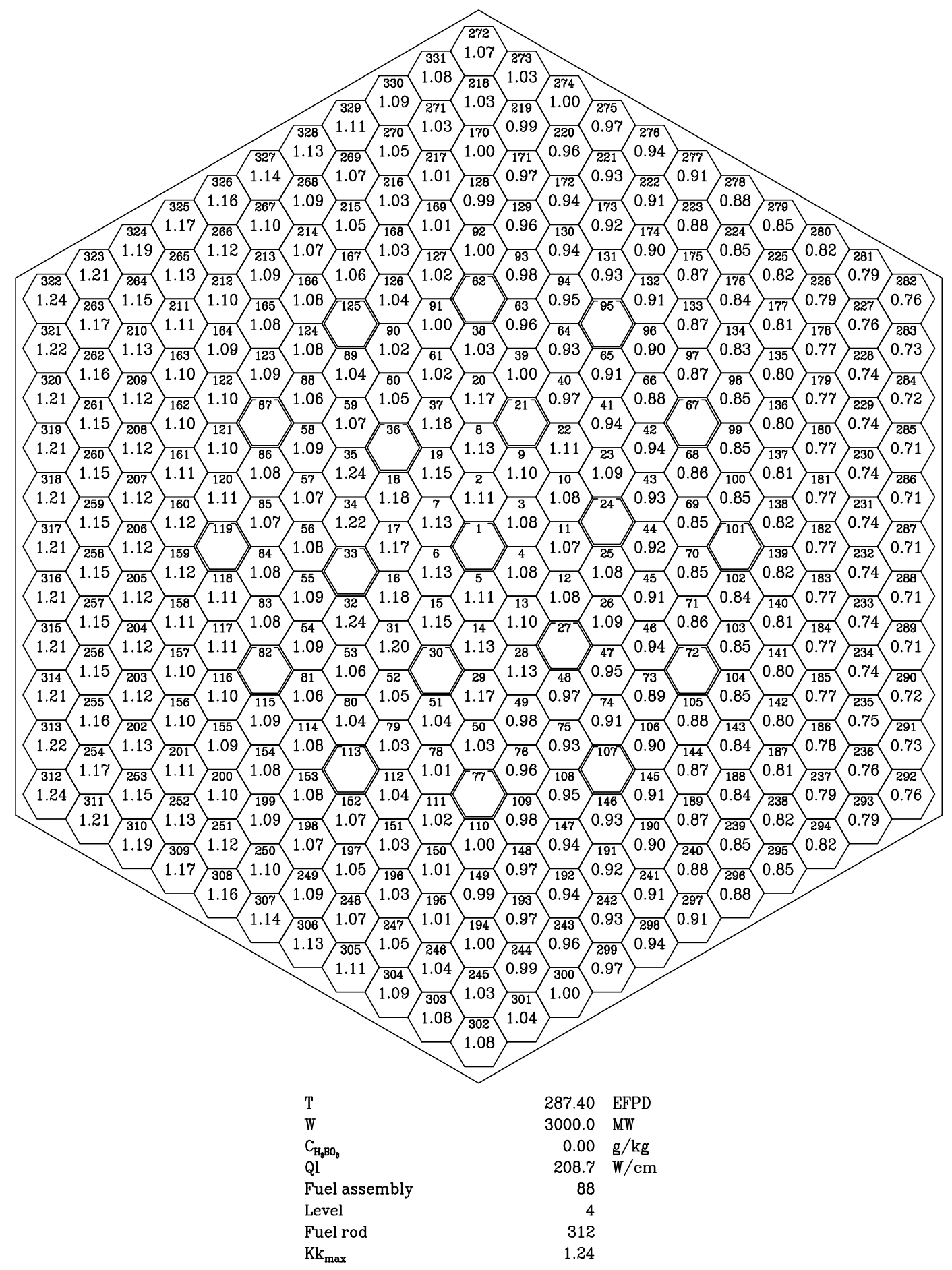


RUSSIAN RESEARCH CENTER KURCHATOV INSTITUTE

Kinetics Parameters of VVER-1000 Core with 3 MOX Lead Test Assemblies to be used for Accident Analysis Codes

Fig.33. Reloading Scheme.

Second Cycle with 3 MOX LTAs

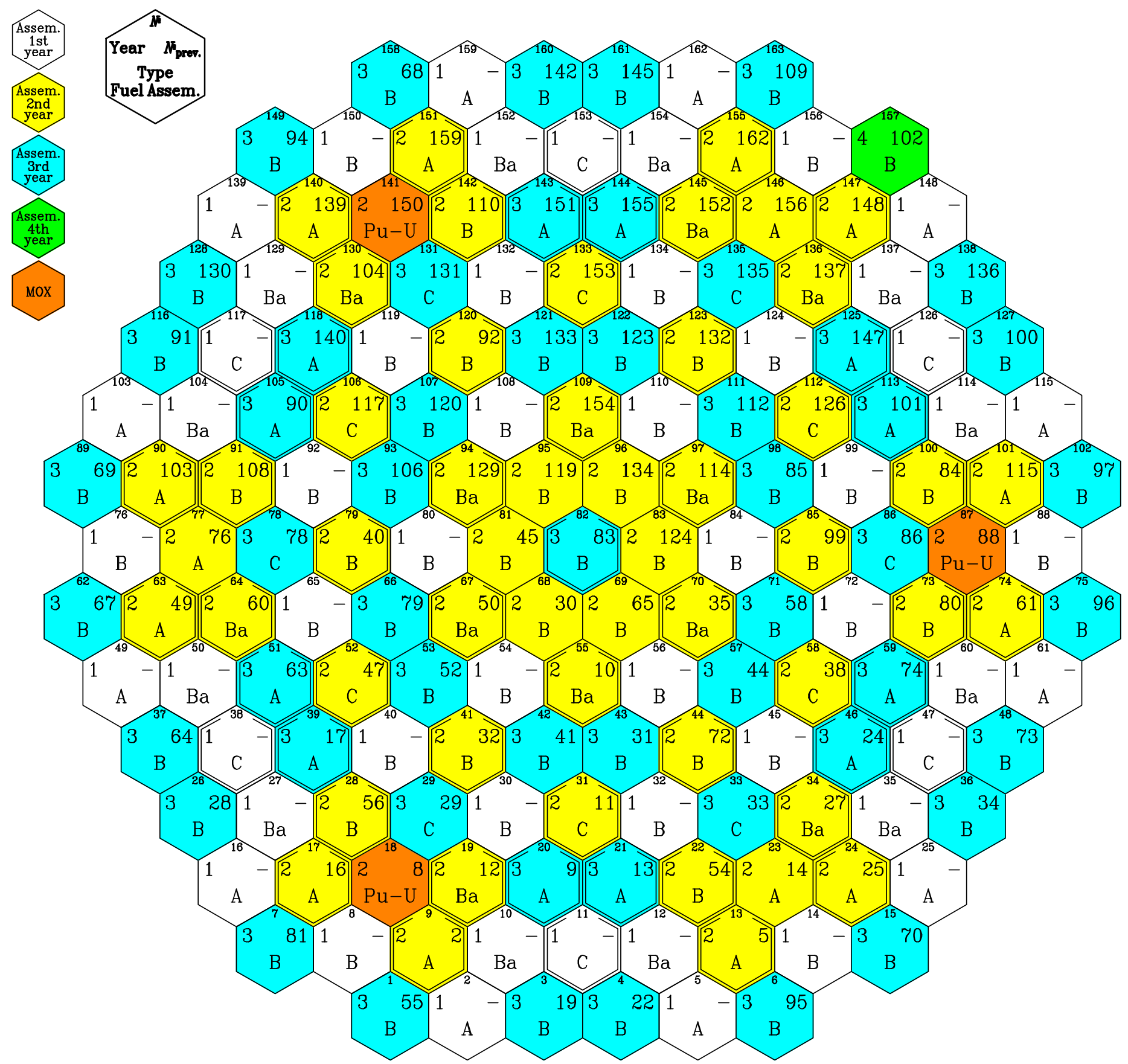


RUSSIAN RESEARCH CENTER KURCHATOV INSTITUTE

Kinetics Parameters of VVER-1000 Core with 3 MOX Lead Test Assemblies to be used for

Accident Analysis Codes

Fig.34. Assembly-by-Assembly Power Distribution.

Second Cycle with 3 MOX LTAs 100\%Pu (4.2-3.0-2.0)

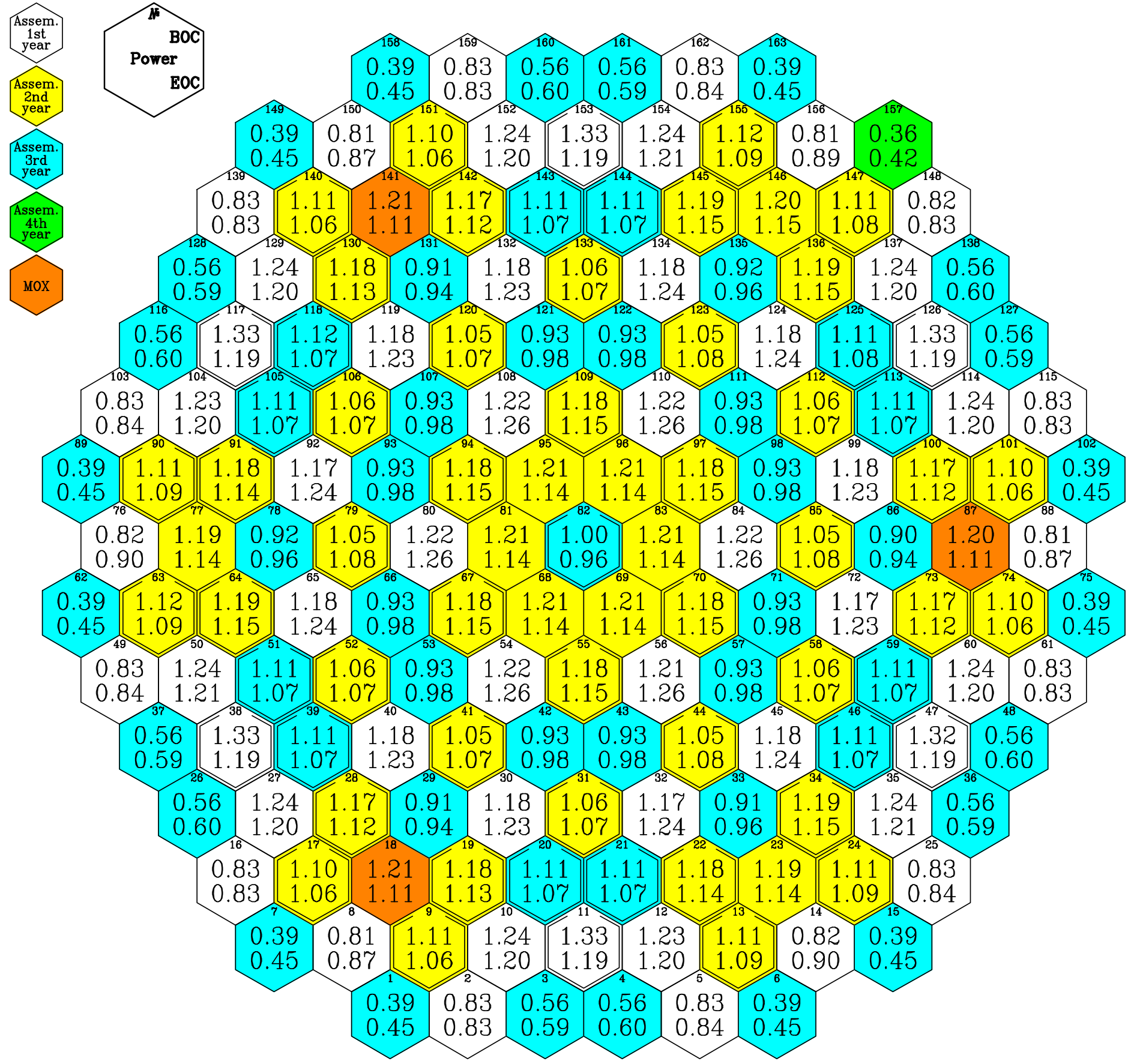


RUSSIAN RESEARCH CENTER KURCHATOV INSTITUTE

Kinetics Parameters of VVER-1000 Core with 3 MOX Lead Test Assemblies to be used for Accident Analysis Codes

Fig.35. Assembly-by-Assembly Temperature Drop Power Distribution. Second Cycle with 3 MOX LTAs 100\% Pu (4.2-3.0-2.0)

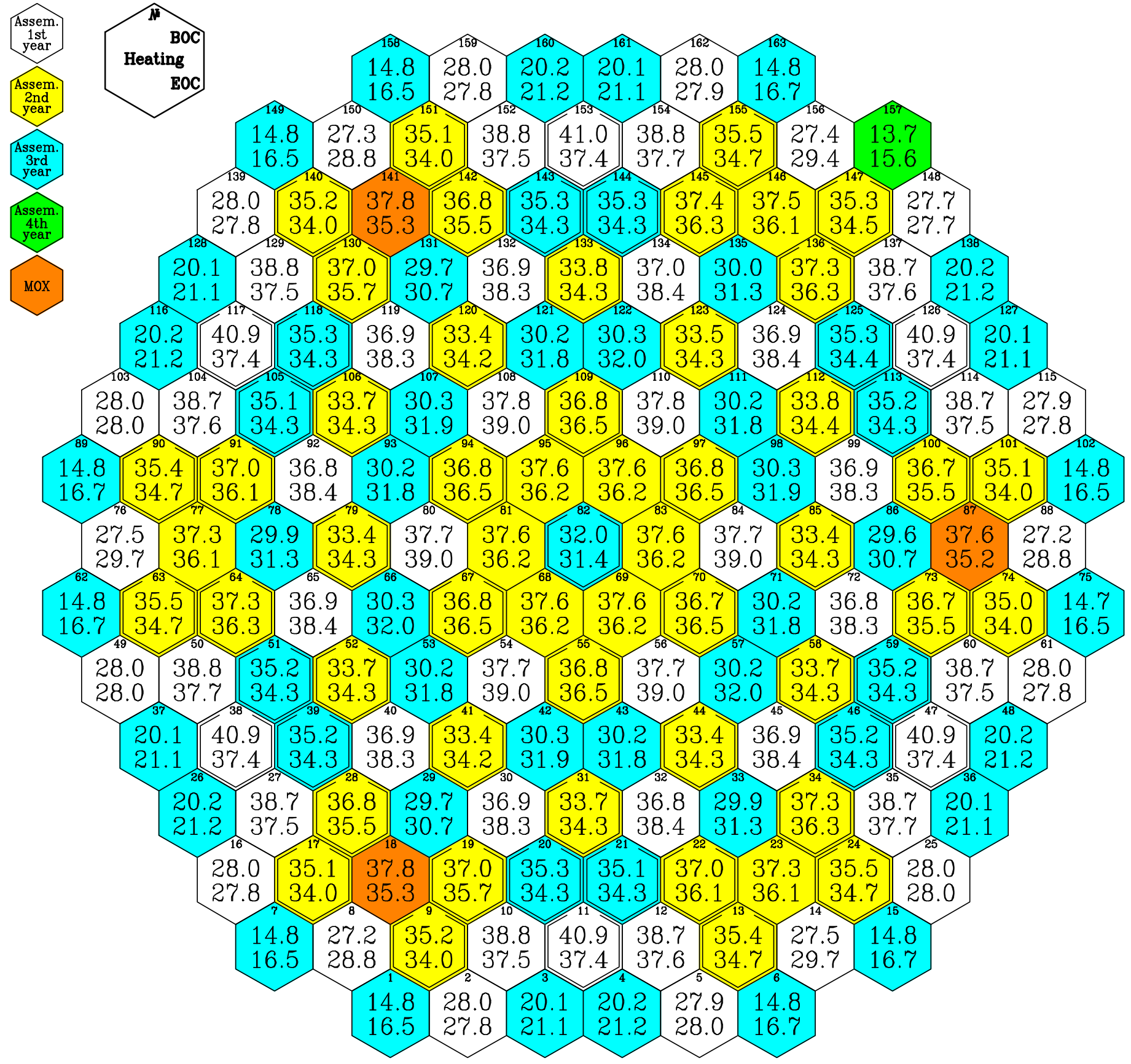


RUSSIAN RESEARCH CENTER KURCHATOV INSTITUTE

Kinetics Parameters of VVER-1000 Core with 3 MOX Lead Test Assemblies to be used for

Accident Analysis Codes

Fig.36. Assembly-by-Assembly Burnup Distribution.

Second Cycle with 3 MOX LTAs 100\%Pu (4.2-3.0-2.0)

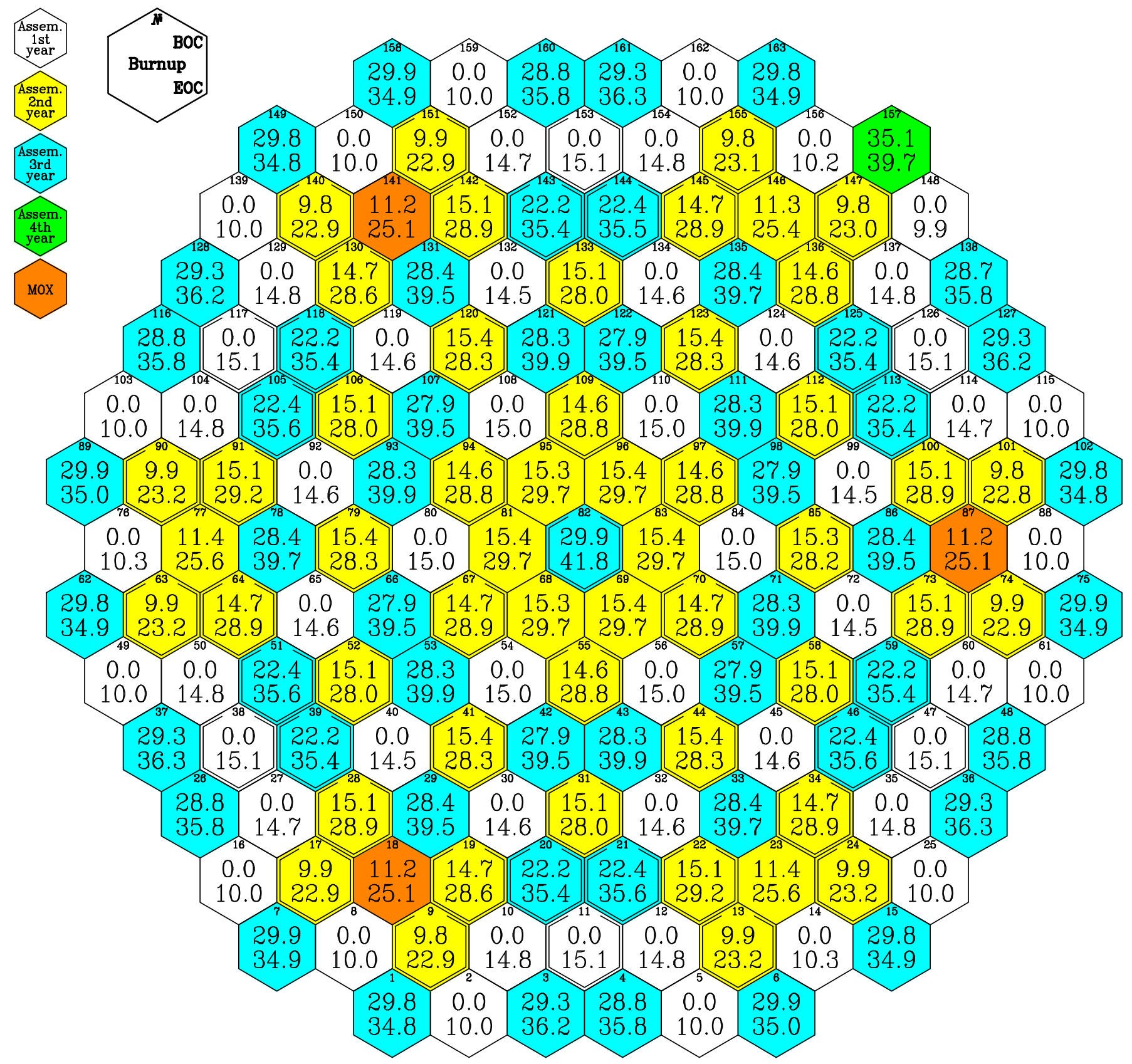


RUSSIAN RESEARCH CENTER KURCHATOV INSTITUTE

Kinetics Parameters of VVER-1000 Core with 3 MOX Lead Test Assemblies to be used for Accident Analysis Codes

Fig.37. Assembly-by-Assembly Maximum Linear Pin Power Distribution in BOC. Second Cycle with 3 MOX LTAs 100\%Pu (4.2-3.0-2.0)

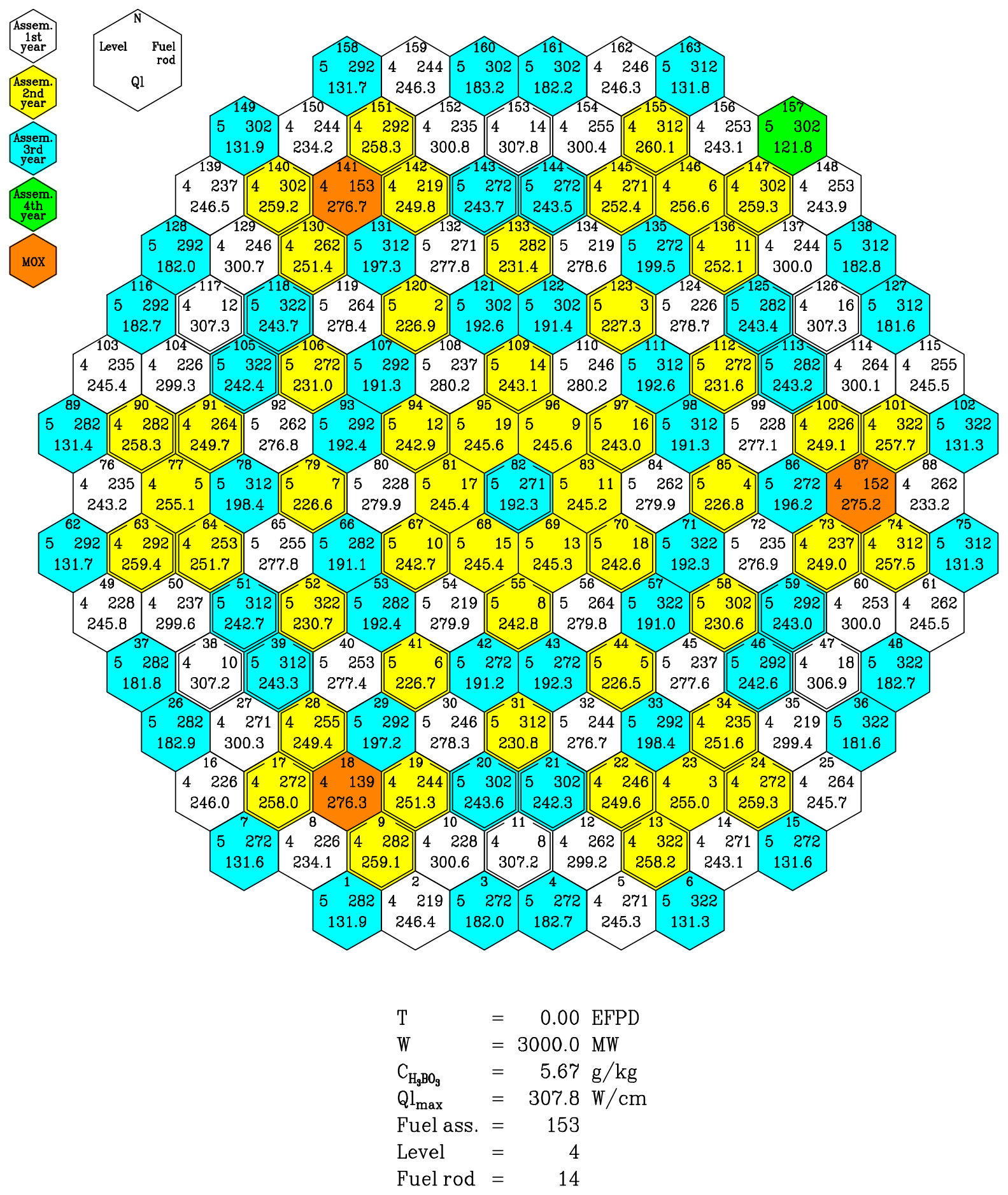


RUSSIAN RESEARCH CENTER KURCHATOV INSTITUTE

Kinetics Parameters of VVER-1000 Core with 3 MOX Lead Test Assemblies to be used for Accident Analysis Codes

Fig.38. Assembly-by-Assembly Maximum Linear Pin Power Distribution in EOC. Second Cycle with 3 MOX LTAs 100\%Pu (4.2-3.0-2.0)

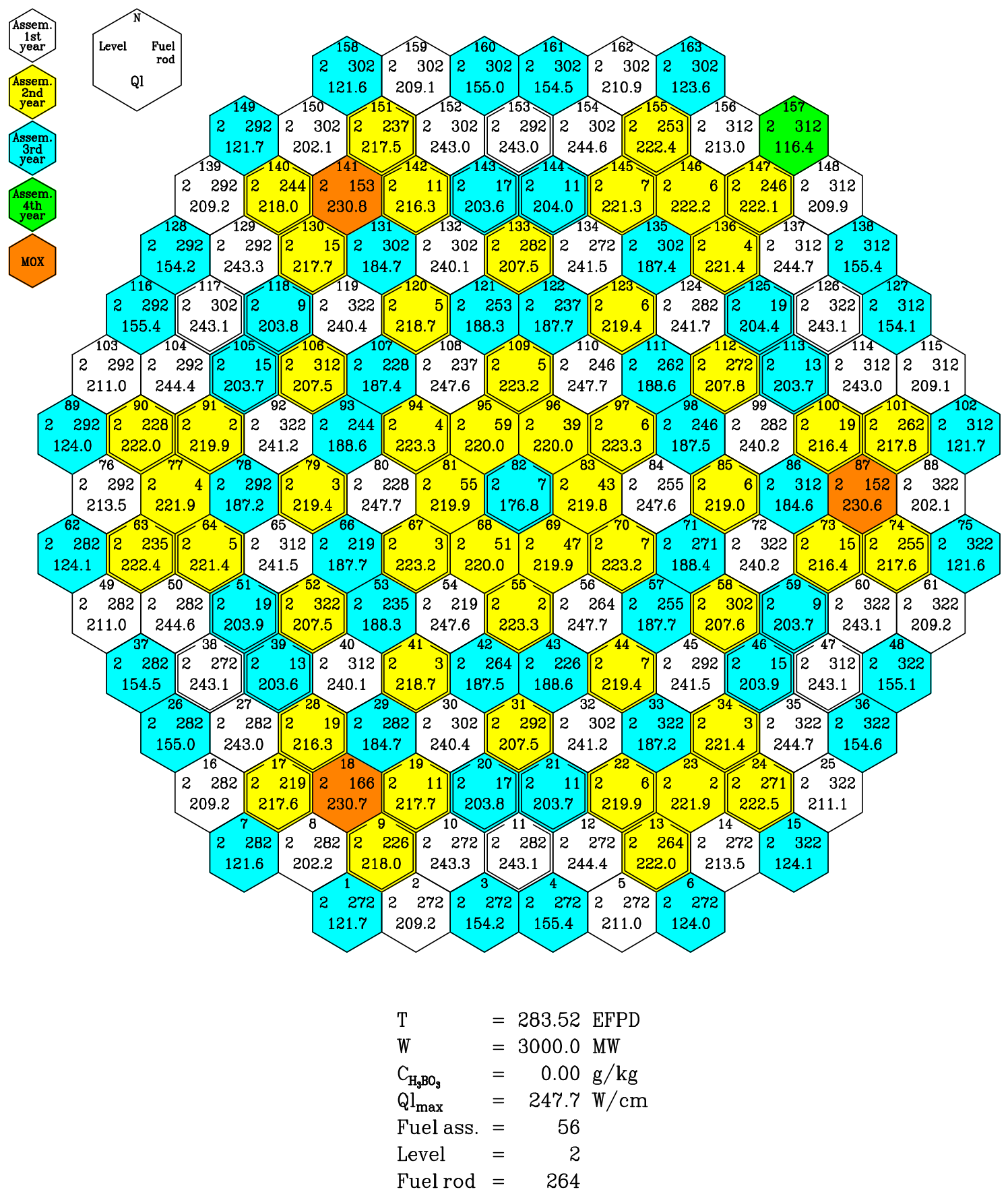


RUSSIAN RESEARCH CENTER KURCHATOV INSTITUTE

Kinetics Parameters of VVER-1000 Core with 3 MOX Lead Test Assemblies to be used for Accident Analysis Codes

Fig.39. Pin-by-Pin Power Distribution in the Most Powered Assembly in BOC. Second Cycle with 3 MOX LTAs 100\%Pu (4.2-3.0-2.0)

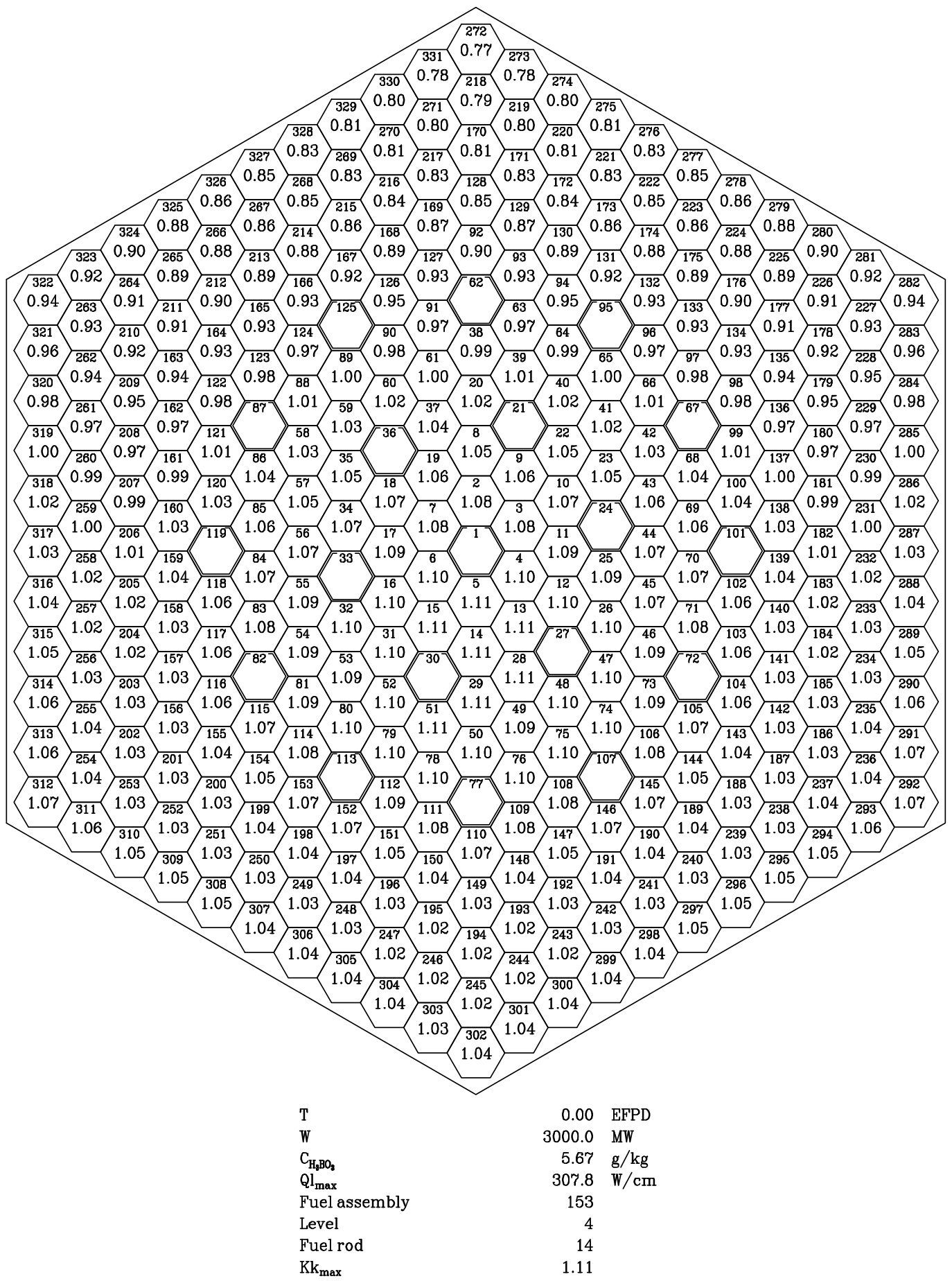


RUSSIAN RESEARCH CENTER KURCHATOV INSTITUTE

Kinetics Parameters of VVER-1000 Core with 3 MOX Lead Test Assemblies to be used for Accident Analysis Codes

Fig.40. Pin-by-Pin Power Distribution in the Most Powered Assembly in EOC. Second Cycle with 3 MOX LTAs 100\%Pu (4.2-3.0-2.0)

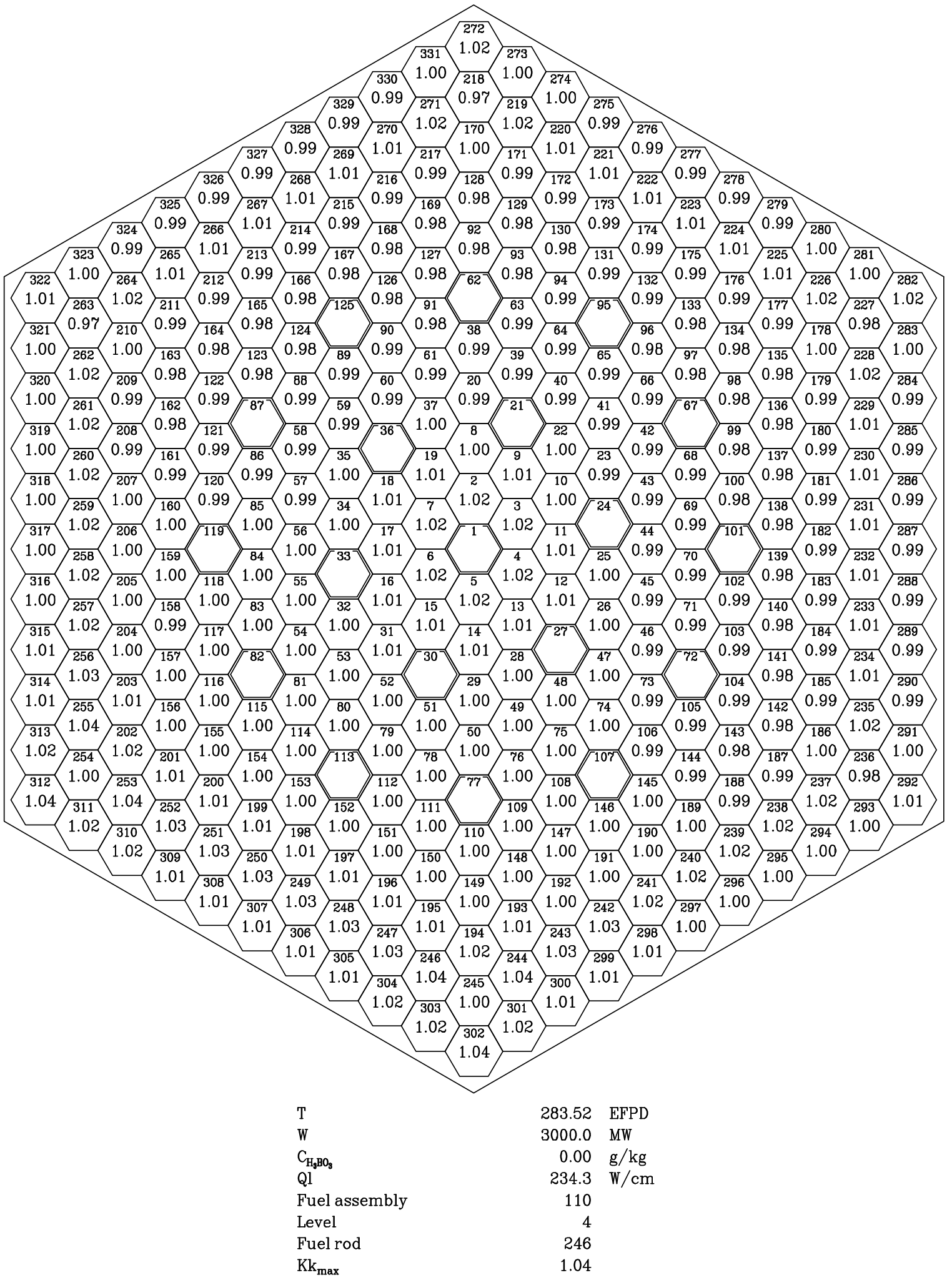


RUSSIAN RESEARCH CENTER KURCHATOV INSTITUTE

Kinetics Parameters of VVER-1000 Core with 3 MOX Lead Test Assemblies to be used for Accident Analysis Codes

Fig.41. Pin-by-Pin Power Distribution in MOX LTA in BOC. Second Cycle with 3 MOX LTAs 100\% Pu (4.2-3.0-2.0)

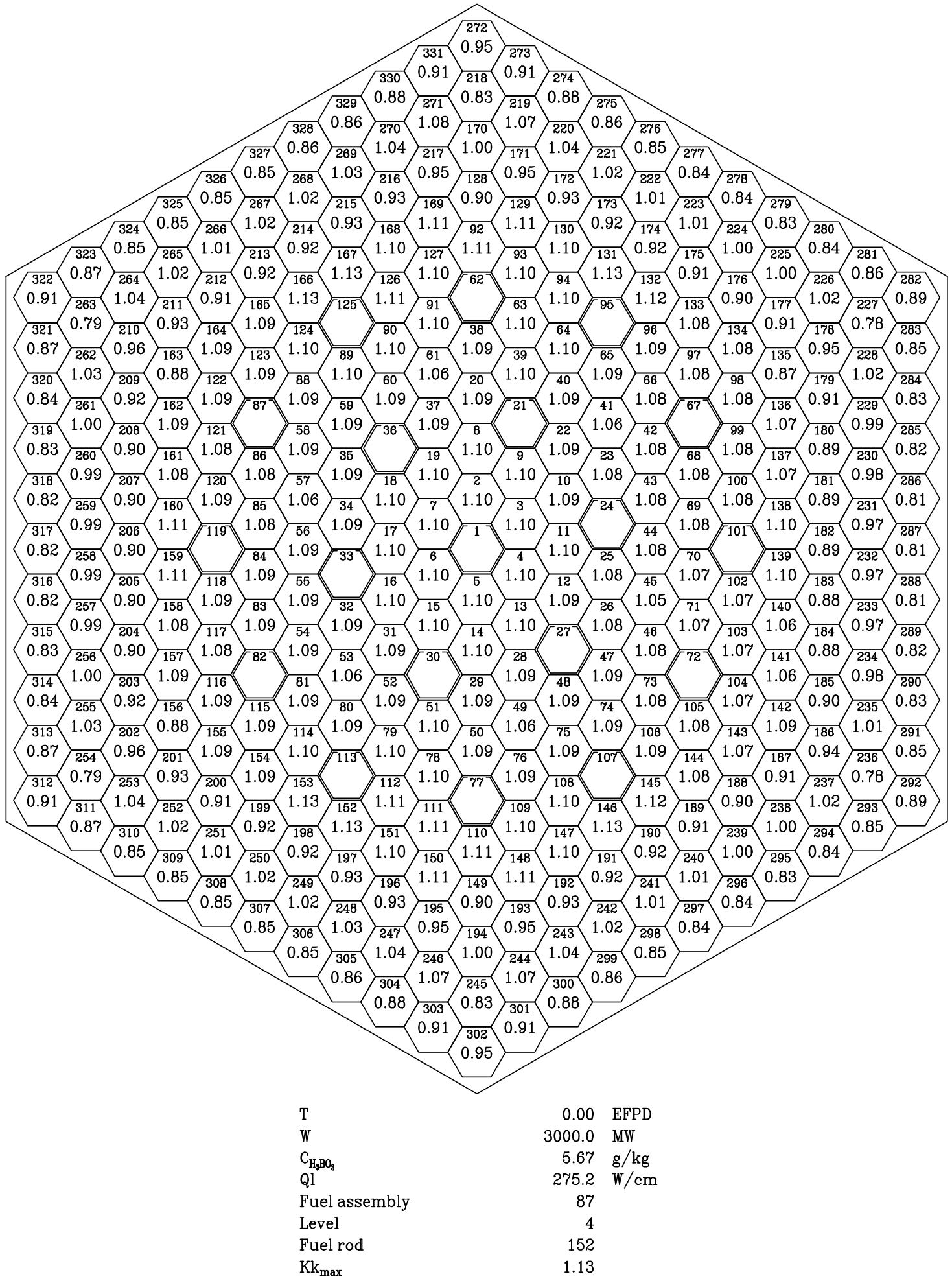


RUSSIAN RESEARCH CENTER KURCHATOV INSTITUTE

Kinetics Parameters of VVER-1000 Core with 3 MOX Lead Test Assemblies to be used for Accident Analysis Codes

Fig.42. Pin-by-Pin Power Distribution in MOX LTA in EOC. Second Cycle with 3 MOX LTAs 100\% Pu (4.2-3.0-2.0)

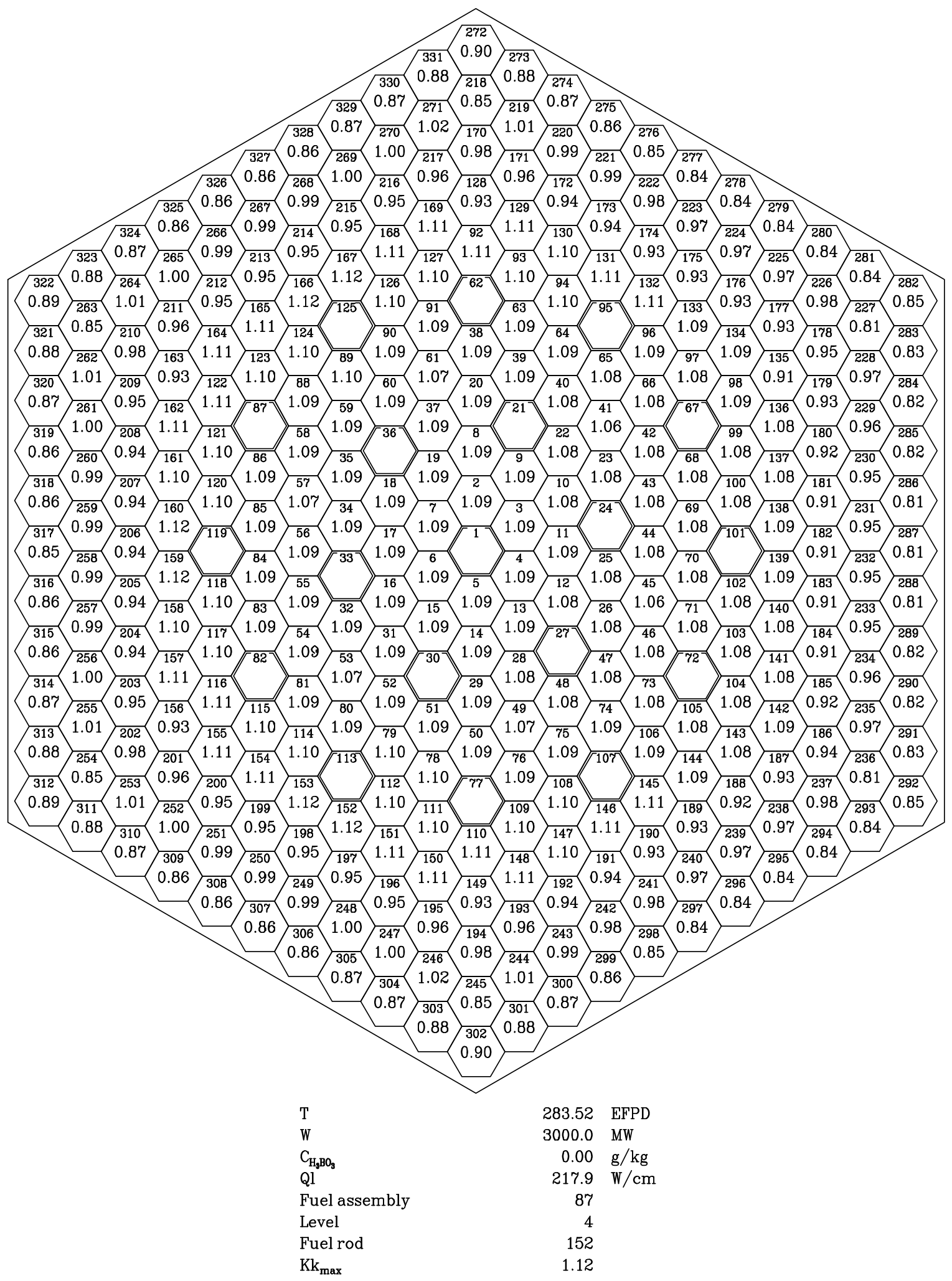


RUSSIAN RESEARCH CENTER KURCHATOV INSTITUTE

Kinetics Parameters of VVER-1000 Core with 3 MOX Lead Test Assemblies to be used for

Accident Analysis Codes

Fig.43. Assembly-by-Assembly Power Distribution.

Second Cycle with 3 MOX LTAs of "Island" Type (Pu3.8-2.8-U3.7)

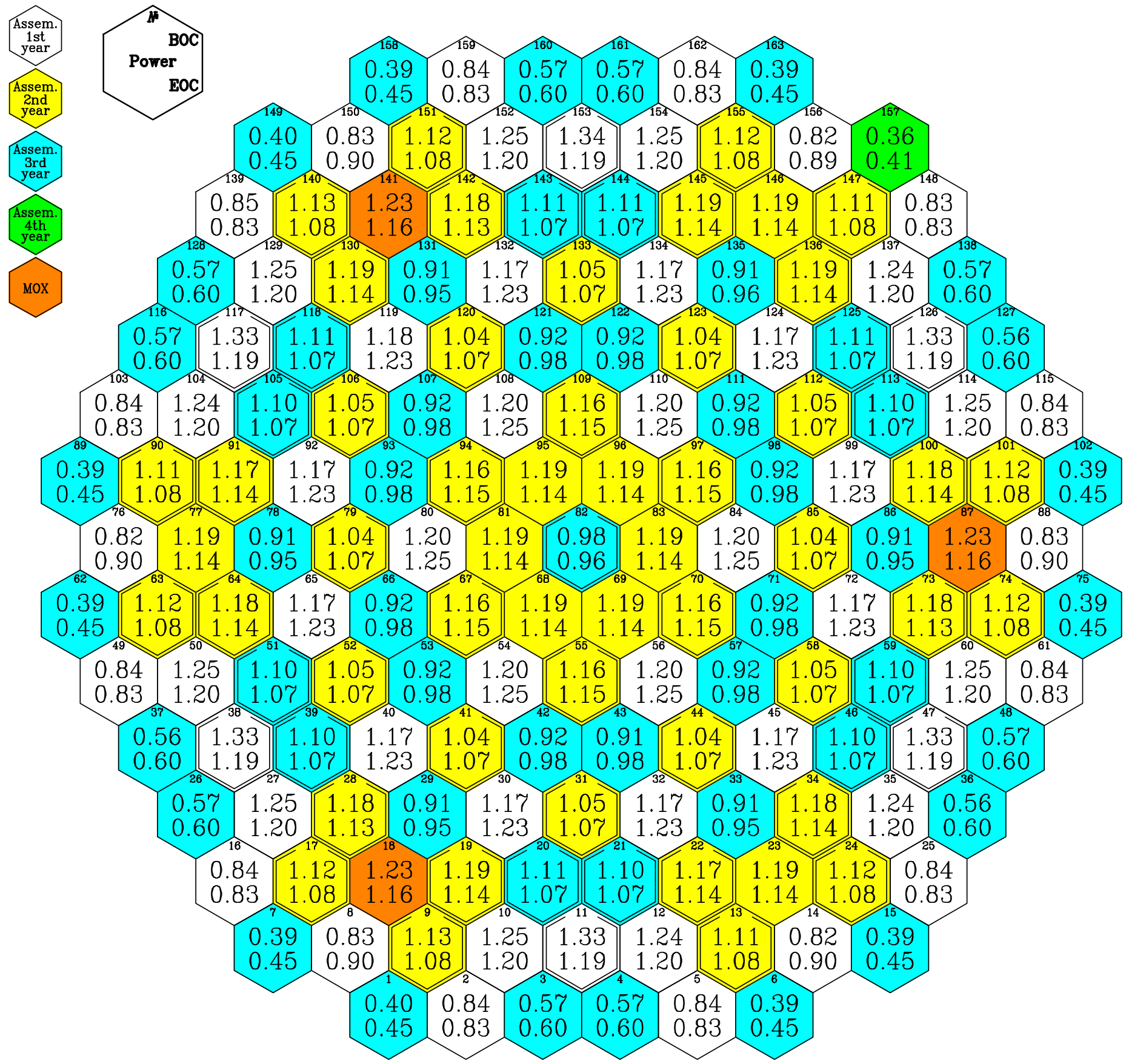


RUSSIAN RESEARCH CENTER KURCHATOV INSTITUTE

Kinetics Parameters of VVER-1000 Core with 3 MOX Lead Test Assemblies to be used for

Accident Analysis Codes

Fig.44. Assembly-by-Assembly Burnup Distribution.

Second Cycle with 3 MOX LTAs of "Island" Type (Pu3.8-2.8-U3.7)

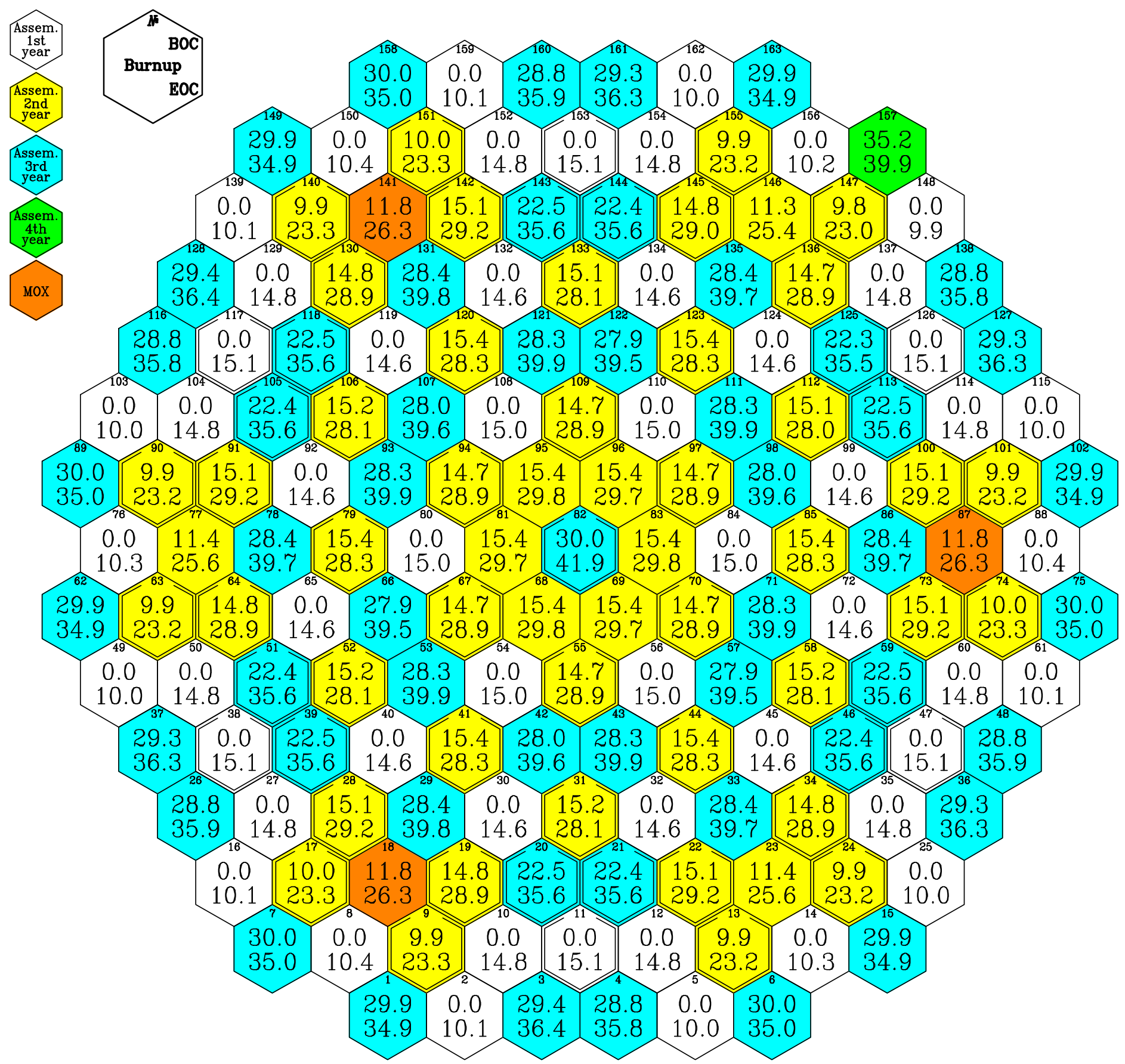


RUSSIAN RESEARCH CENTER KURCHATOV INSTITUTE

Kinetics Parameters of VVER-1000 Core with 3 MOX Lead Test Assemblies to be used for

Accident Analysis Codes

Fig.45. Assembly-by-Assembly Temperature Drop Distribution.

Second Cycle with 3 MOX LTAs of "Island" Type (Pu3.8-2.8-U3.7)

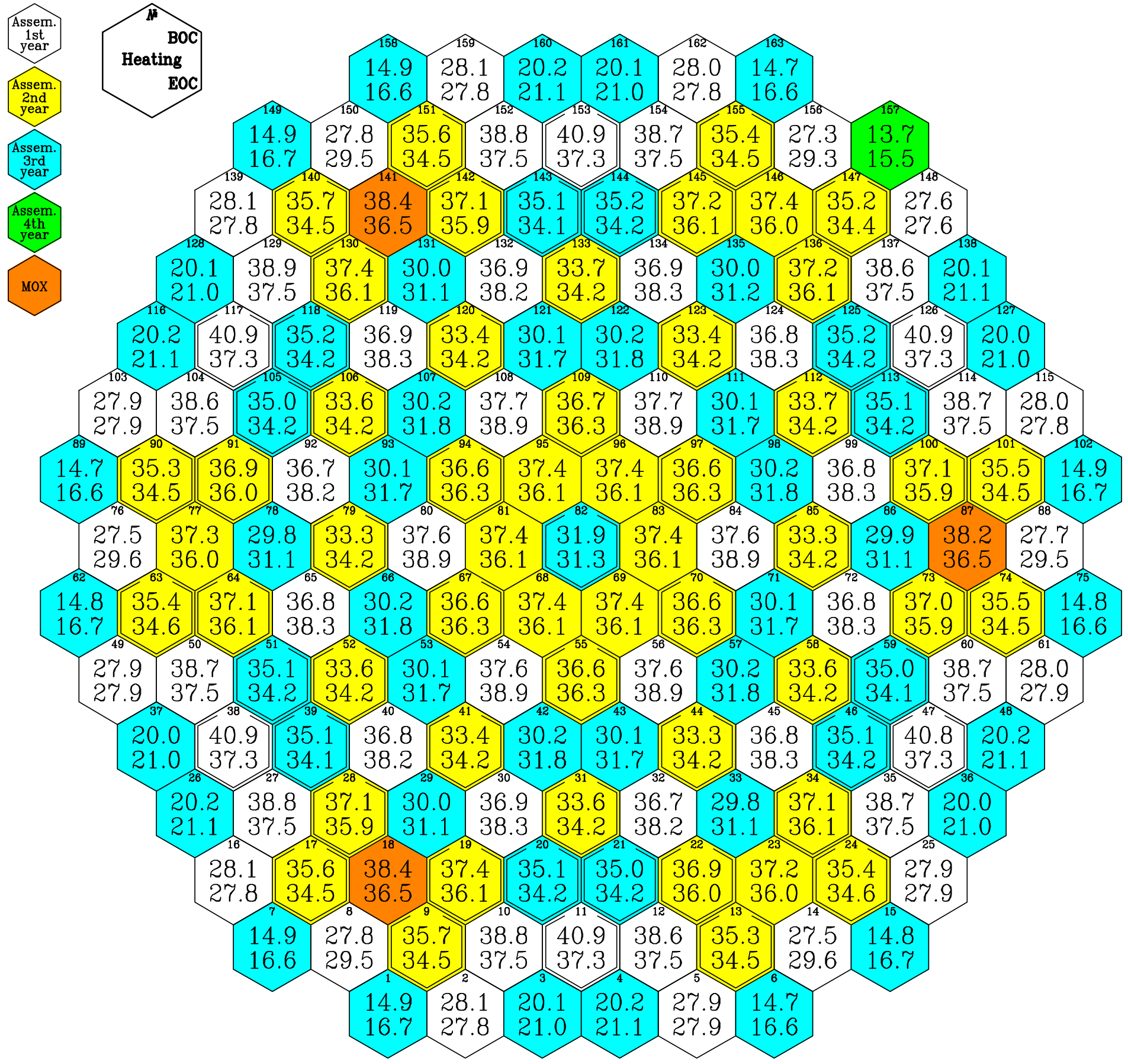


RUSSIAN RESEARCH CENTER KURCHATOV INSTITUTE

Kinetics Parameters of VVER-1000 Core with 3 MOX Lead Test Assemblies to be used for Accident Analysis Codes

Fig.46. Assembly-by-Assembly Maximum Linear Pin Power Distribution in BOC. Second Cycle with 3 MOX LTAs of "Island" Type ( Pu3.8-2.8-U3.7)

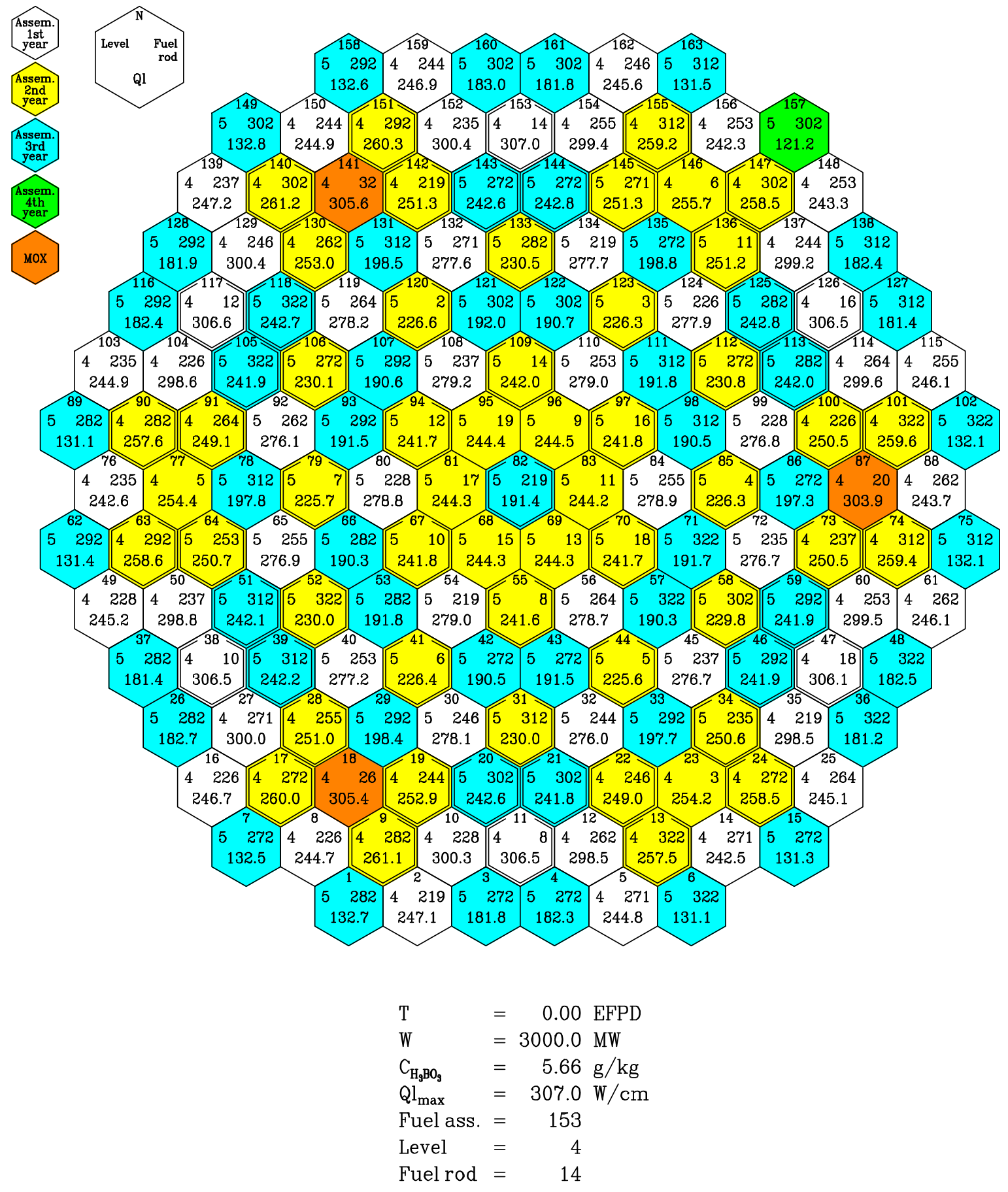


RUSSIAN RESEARCH CENTER KURCHATOV INSTITUTE

Kinetics Parameters of VVER-1000 Core with 3 MOX Lead Test Assemblies to be used for Accident Analysis Codes

Fig.47. Assembly-by-Assembly Maximum Linear Pin Power Distribution in EOC. Second Cycle with 3 MOX LTAs of "Island" Type (Pu3.8-2.8-U3.7)

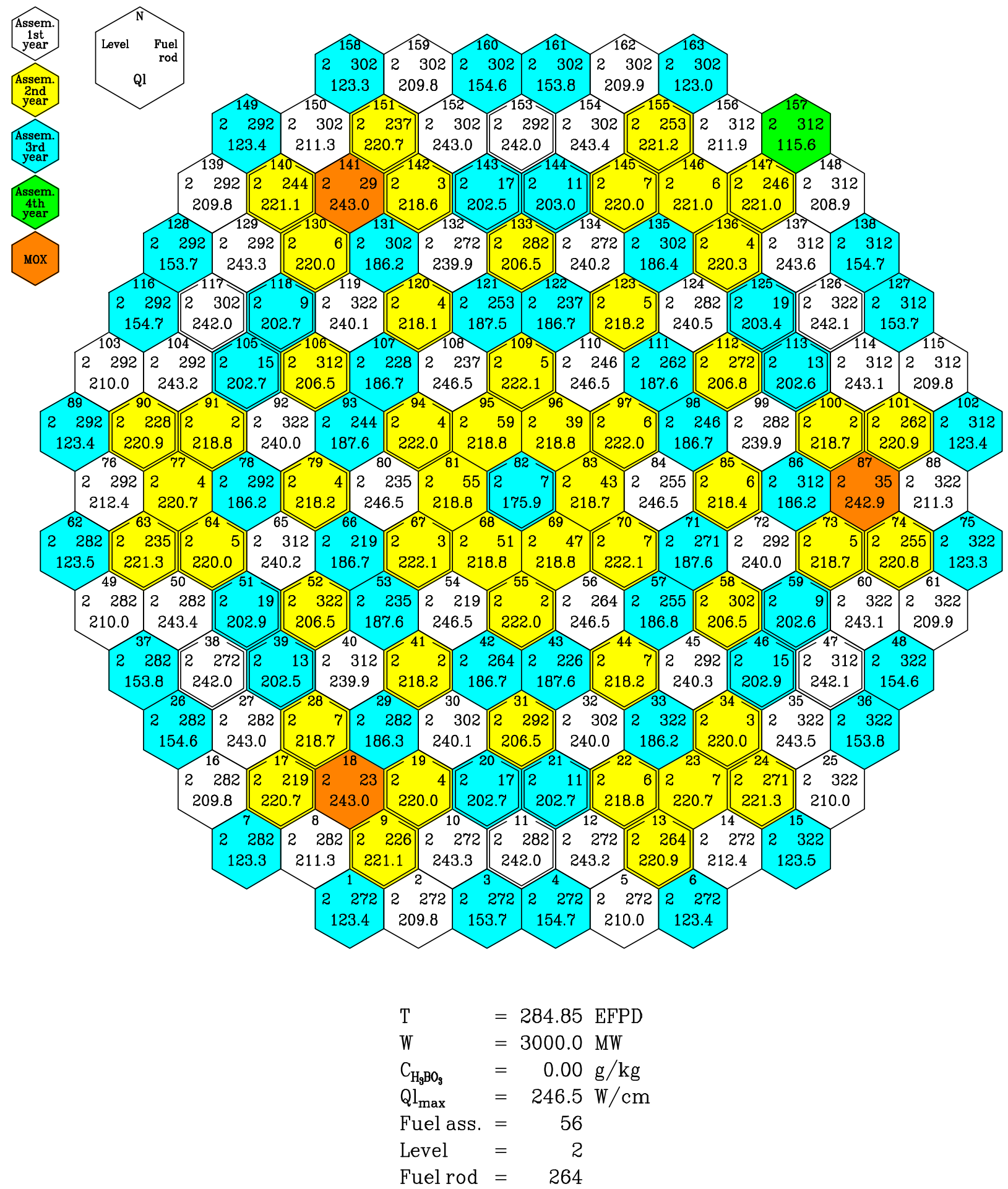


RUSSIAN RESEARCH CENTER KURCHATOV INSTITUTE

Kinetics Parameters of VVER-1000 Core with 3 MOX Lead Test Assemblies to be used for Accident Analysis Codes

Fig.48. Pin-by-Pin Power Distribution in the Most Powered Assembly in BOC. Second Cycle with 3 MOX LTAs of "Island" Type ( Pu3.8-2.8-U3.7)

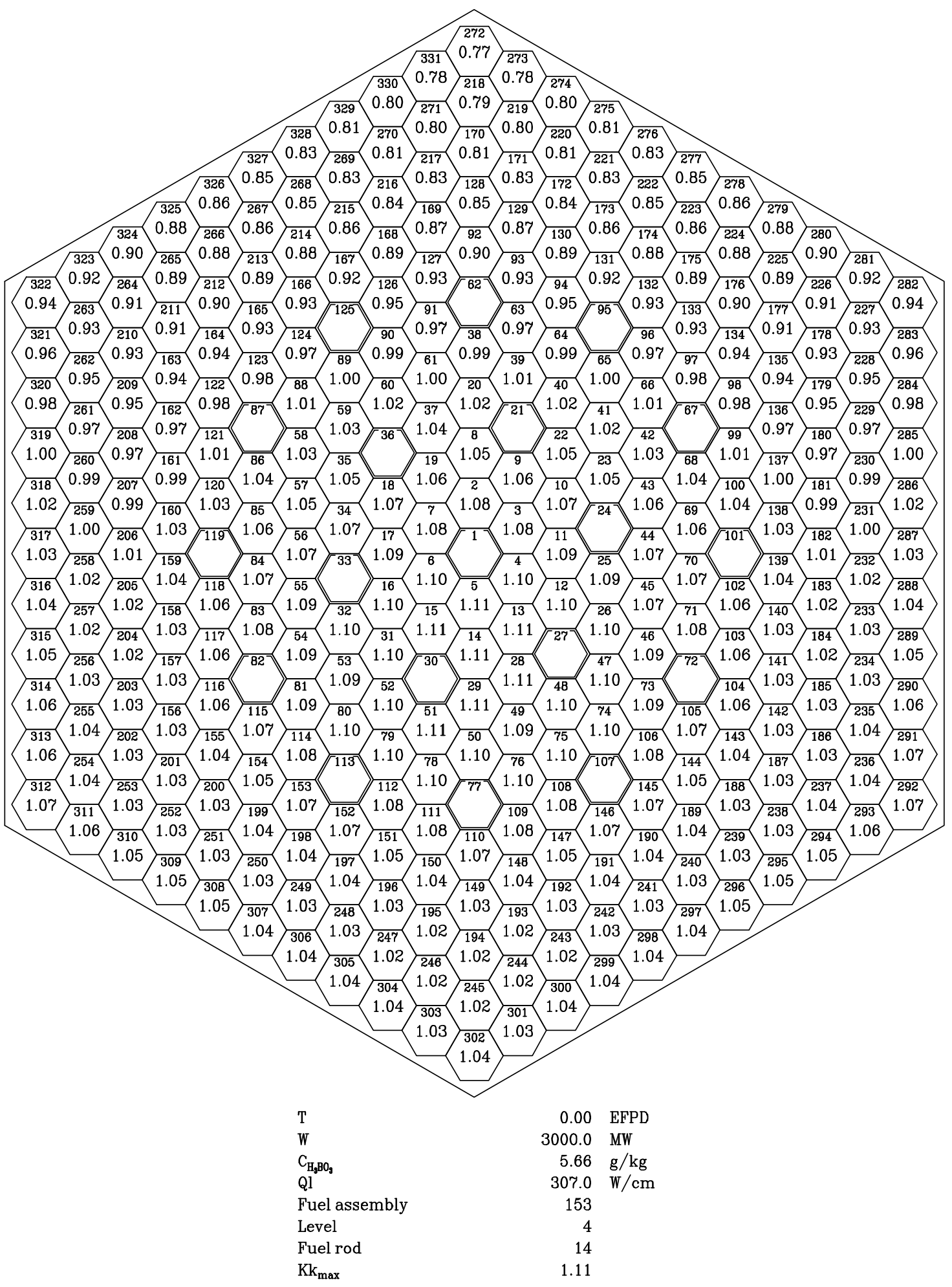


RUSSIAN RESEARCH CENTER KURCHATOV INSTITUTE

Kinetics Parameters of VVER-1000 Core with 3 MOX Lead Test Assemblies to be used for Accident Analysis Codes

Fig.49. Pin-by-Pin Power Distribution in the Most Powered Assembly in EOC. Second Cycle with 3 MOX LTAs of "Island" Type ( Pu3.8-2.8-U3.7)

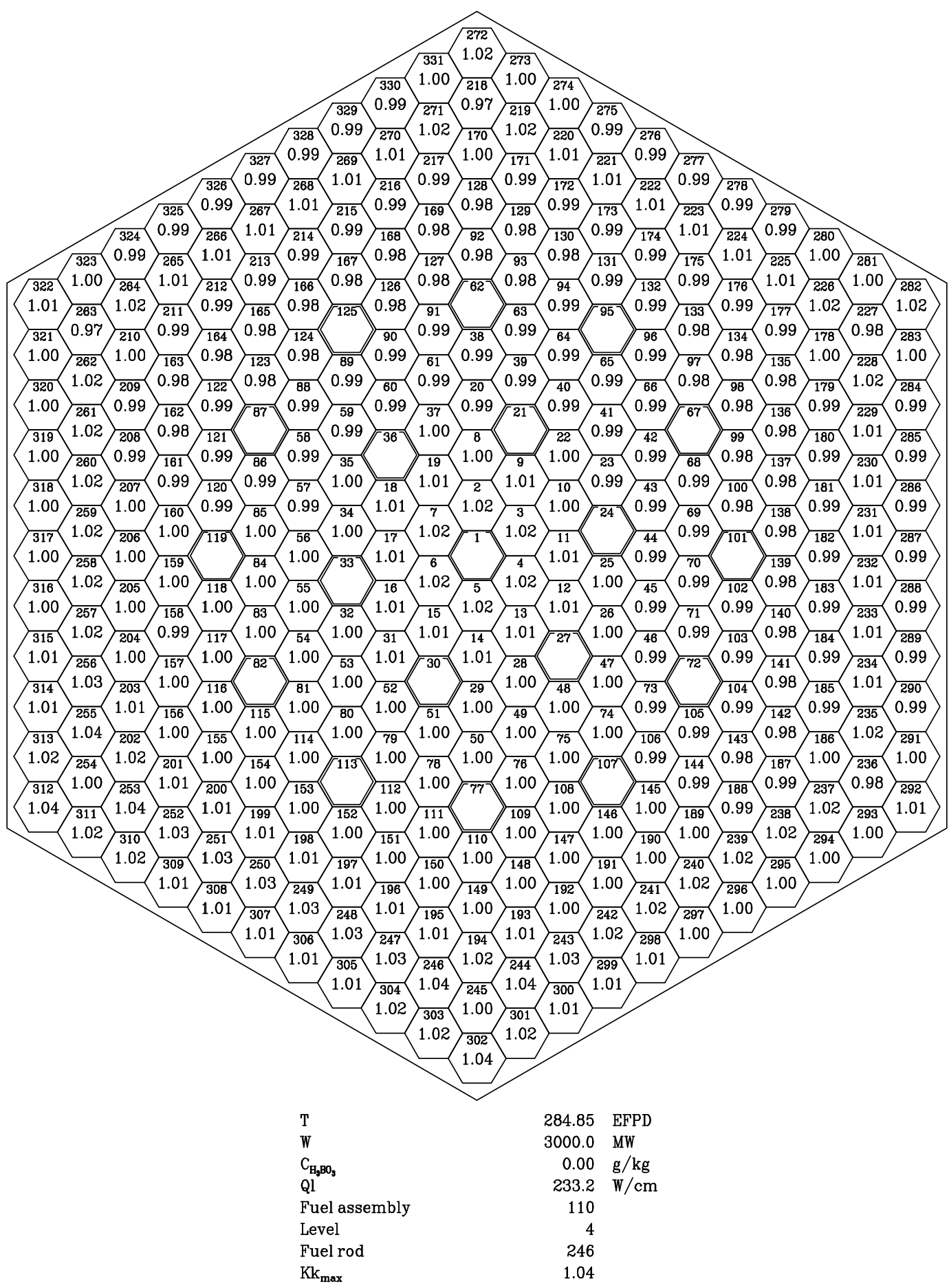


RUSSIAN RESEARCH CENTER KURCHATOV INSTITUTE

Kinetics Parameters of VVER-1000 Core with 3 MOX Lead Test Assemblies to be used for Accident Analysis Codes

Fig.50. Pin-by-Pin Power Distribution in MOX LTA in BOC. Second Cycle with 3 MOX LTAs of "Island" Type ( Pu3.8-2.8-U3.7)

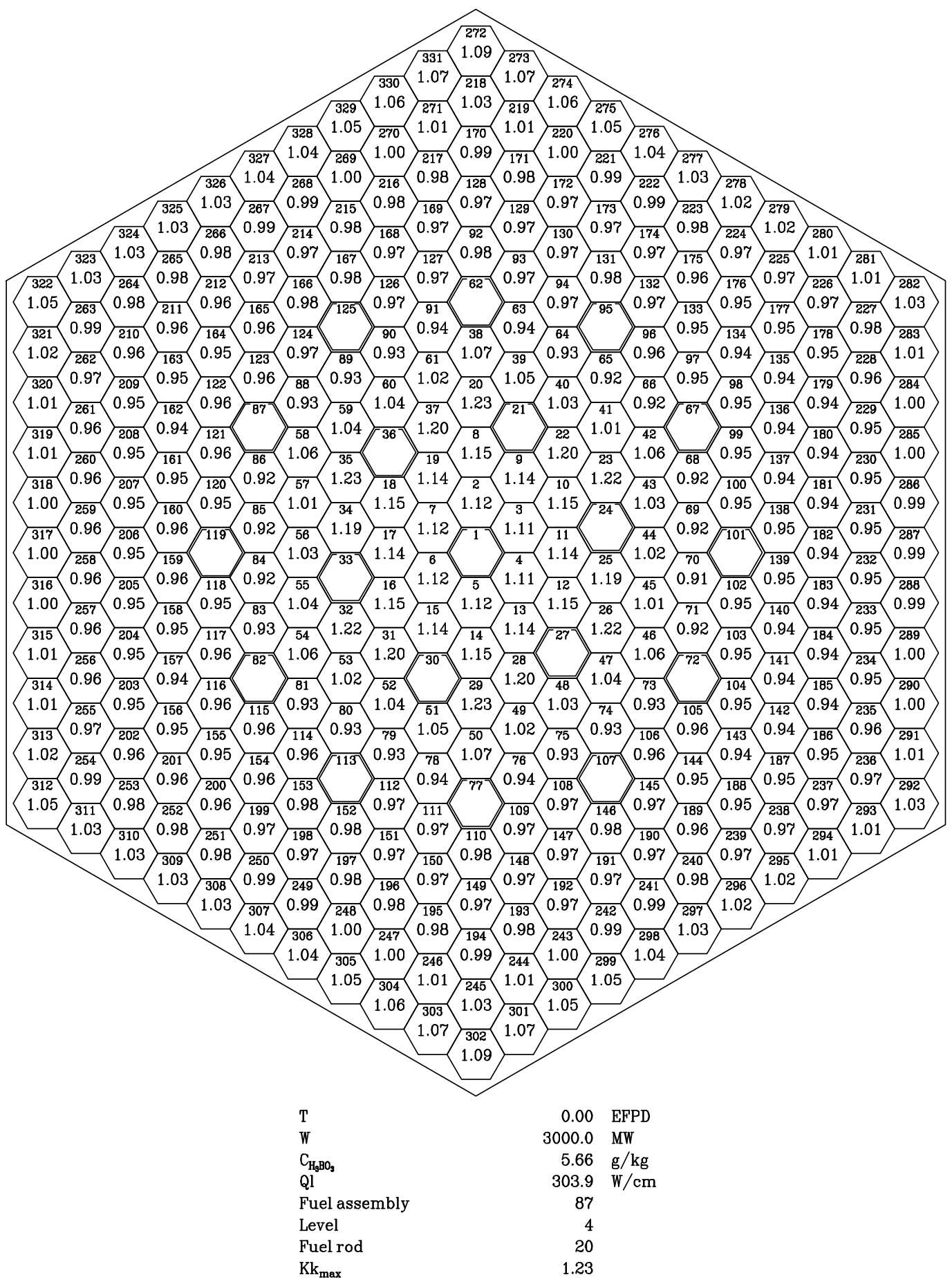


RUSSIAN RESEARCH CENTER KURCHATOV INSTITUTE

Kinetics Parameters of VVER-1000 Core with 3 MOX Lead Test Assemblies to be used for Accident Analysis Codes

Fig.51. Pin-by-Pin Power Distribution in MOX LTA in EOC. Second Cycle with 3 MOX LTAs of "Island" Type ( Pu3.8-2.8-U3.7)

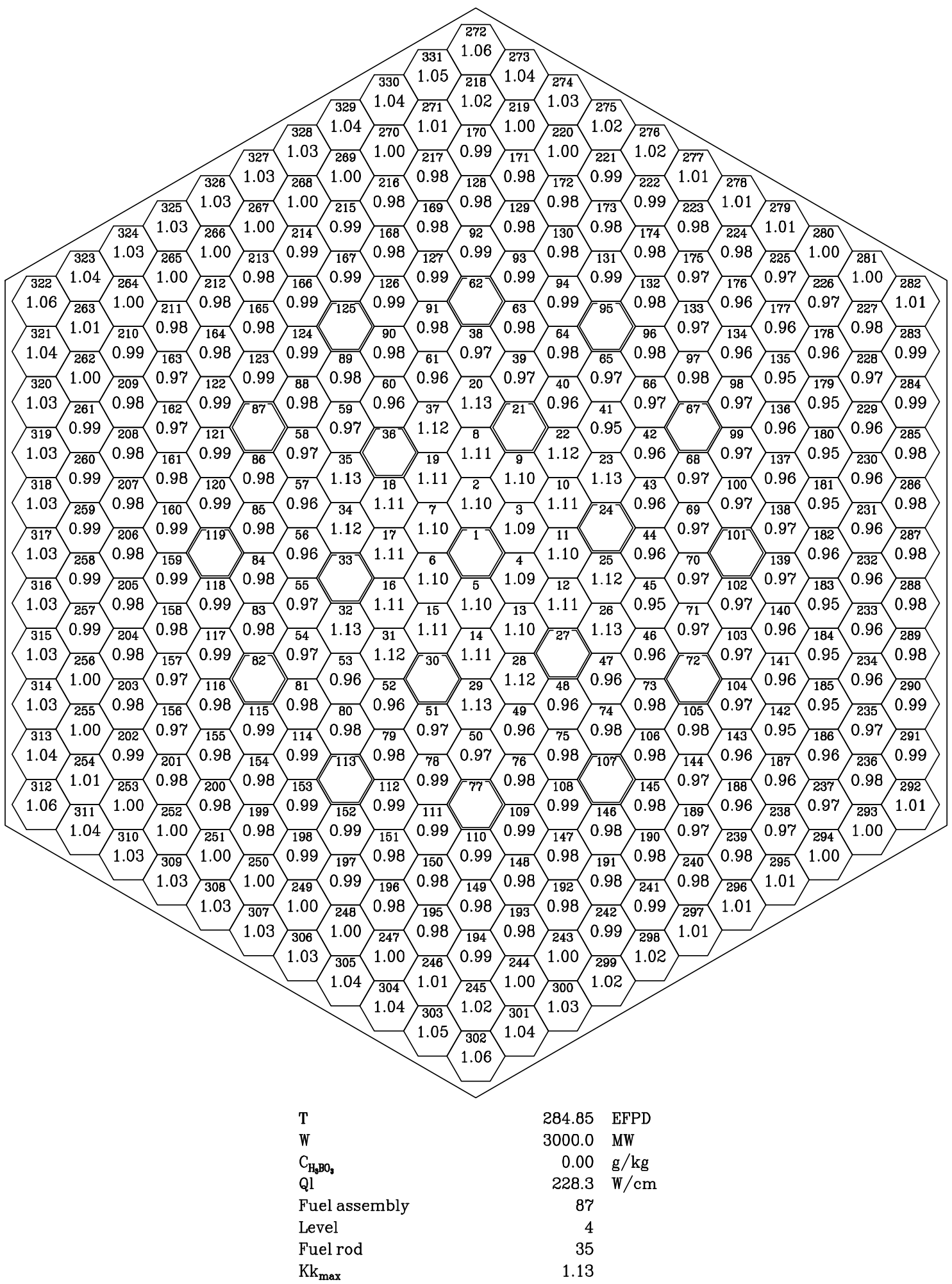


Fig.52. Reloading scheme. Third Cycle with 3 MOX LTAs

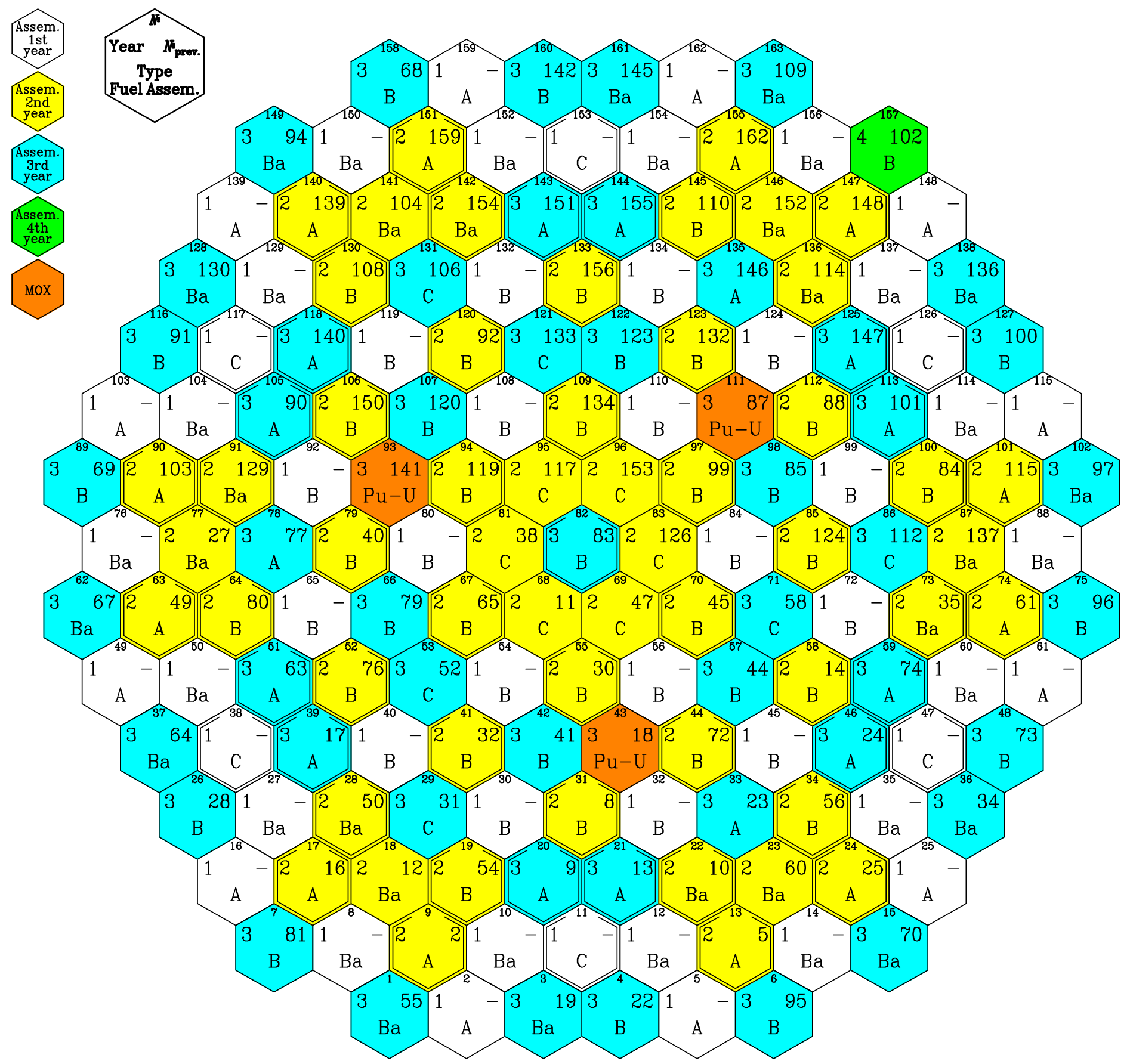


RUSSIAN RESEARCH CENTER KURCHATOV INSTITUTE

Kinetics Parameters of VVER-1000 Core with 3 MOX Lead Test Assemblies to be used for

Accident Analysis Codes

Fig.53. Assembly-by-Assembly Power Distribution.

Third Cycle with 3 MOX LTAs $100 \%$ Pu (4.2-3.0-2.0)

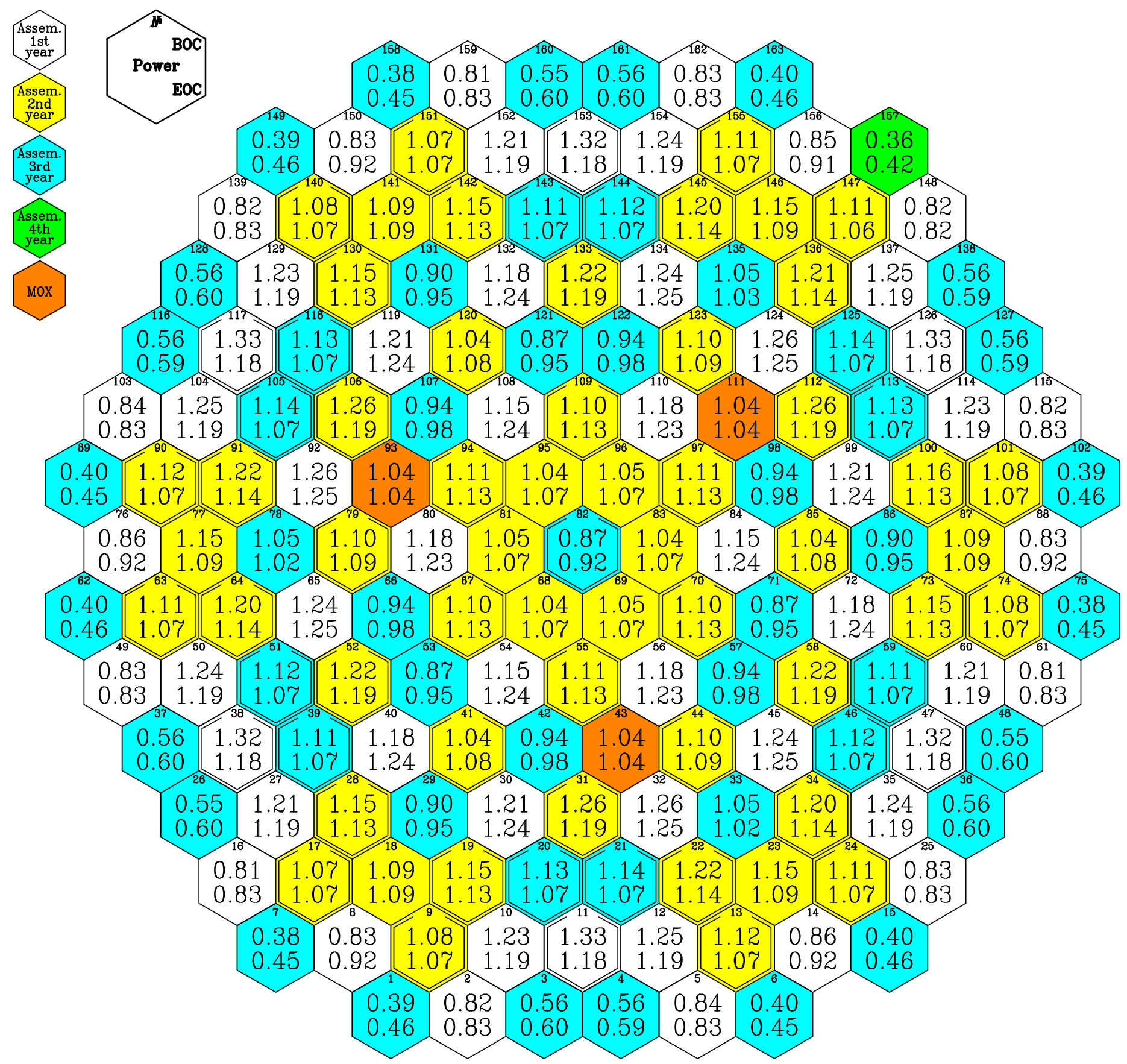


RUSSIAN RESEARCH CENTER KURCHATOV INSTITUTE

Kinetics Parameters of VVER-1000 Core with 3 MOX Lead Test Assemblies to be used for

Accident Analysis Codes

Fig.54. Assembly-by-Assembly Burnup Distribution.

Third Cycle with 3 MOX LTAs $100 \%$ Pu (4.2-3.0-2.0)

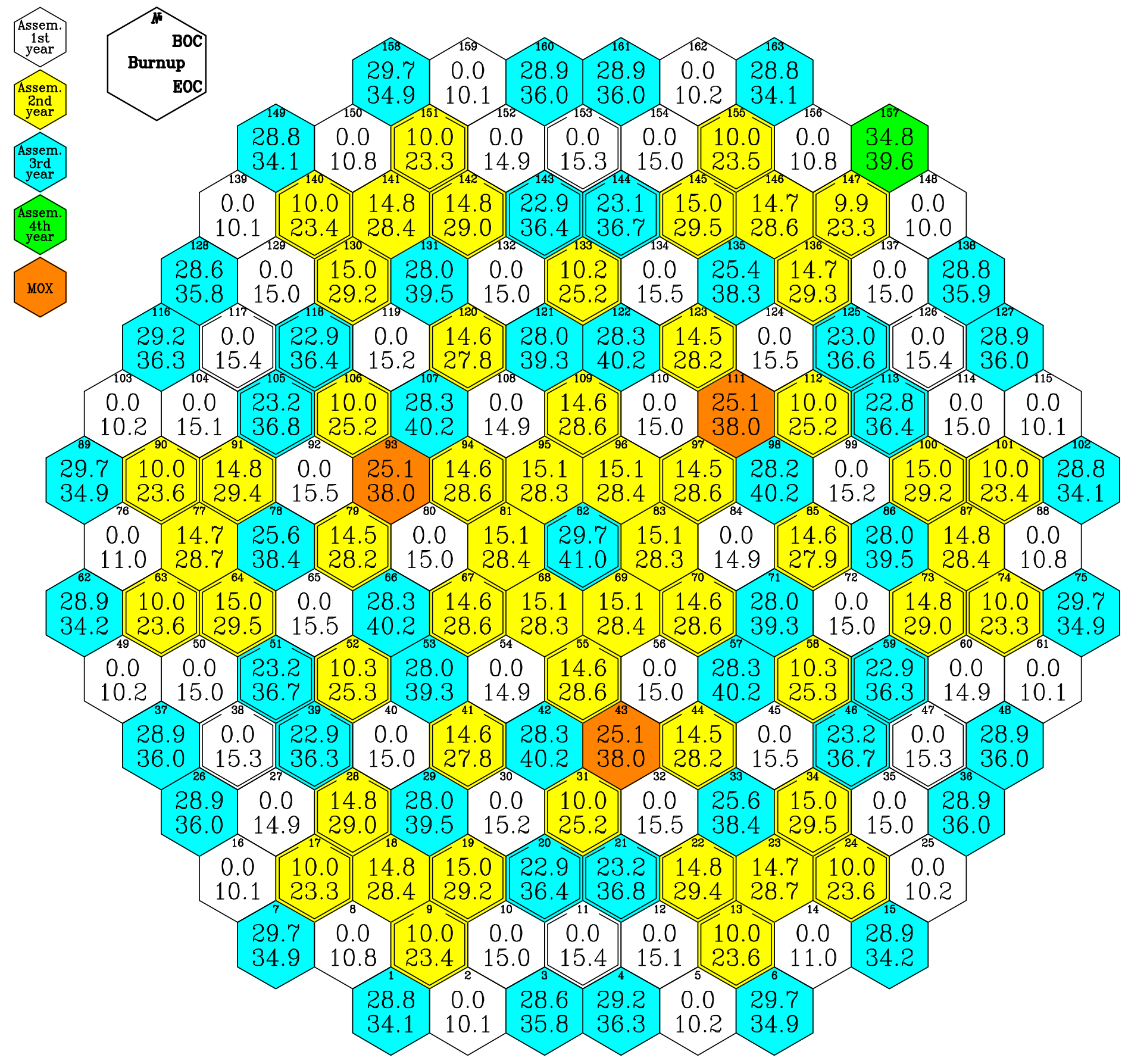


RUSSIAN RESEARCH CENTER KURCHATOV INSTITUTE

Kinetics Parameters of VVER-1000 Core with 3 MOX Lead Test Assemblies to be used for

Accident Analysis Codes

Fig.55. Assembly-by-Assembly Temperature Drop Distribution.

Third Cycle with 3 MOX LTAs $100 \%$ Pu (4.2-3.0-2.0)

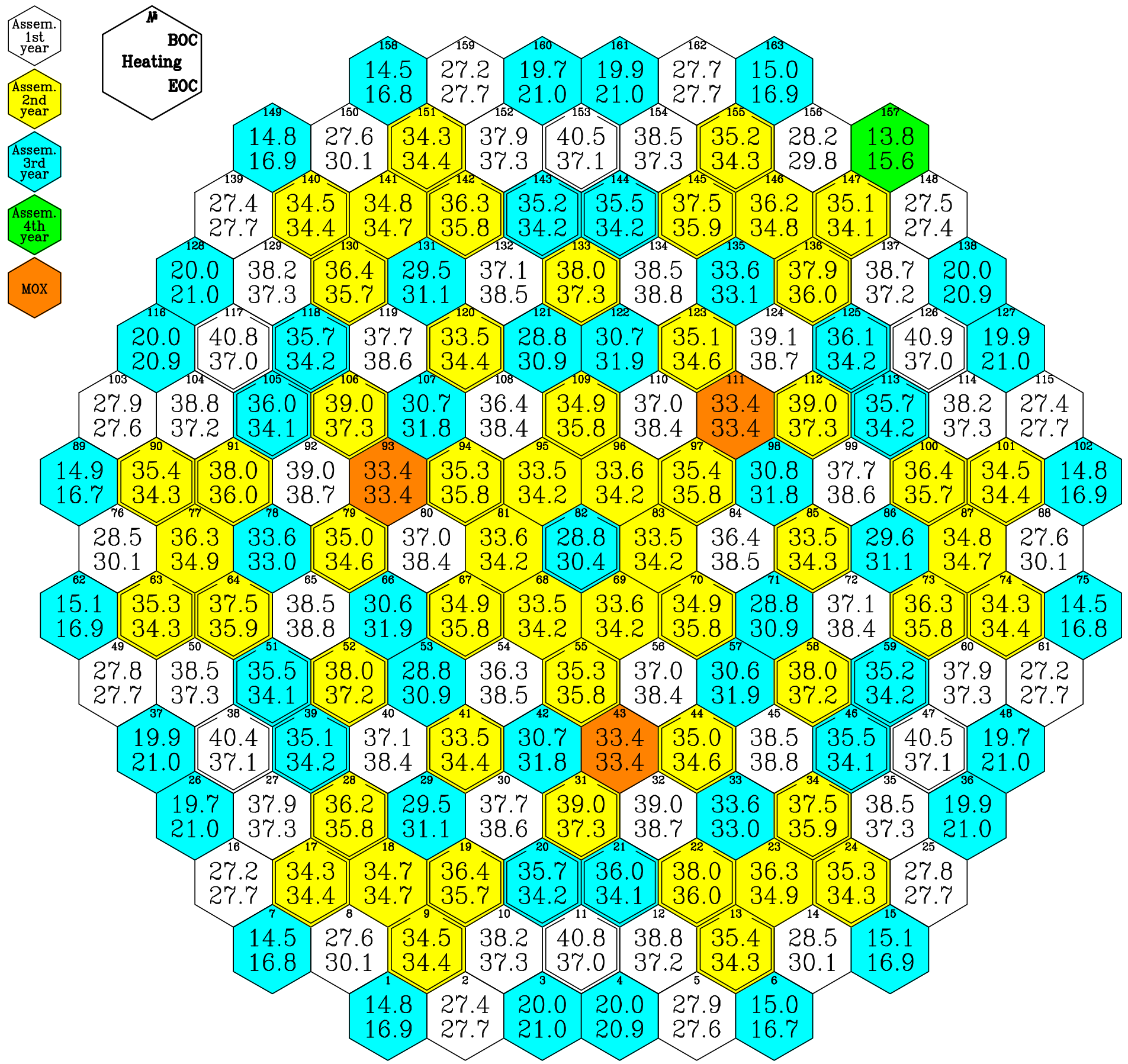


RUSSIAN RESEARCH CENTER KURCHATOV INSTITUTE

Kinetics Parameters of VVER-1000 Core with 3 MOX Lead Test Assemblies to be used for Accident Analysis Codes

Fig.56. Assembly-by-Assembly Maximum Linear Pin Power Distribution in BOC. Third Cycle with 3 MOX LTAs 100\%Pu (4.2-3.0-2.0)

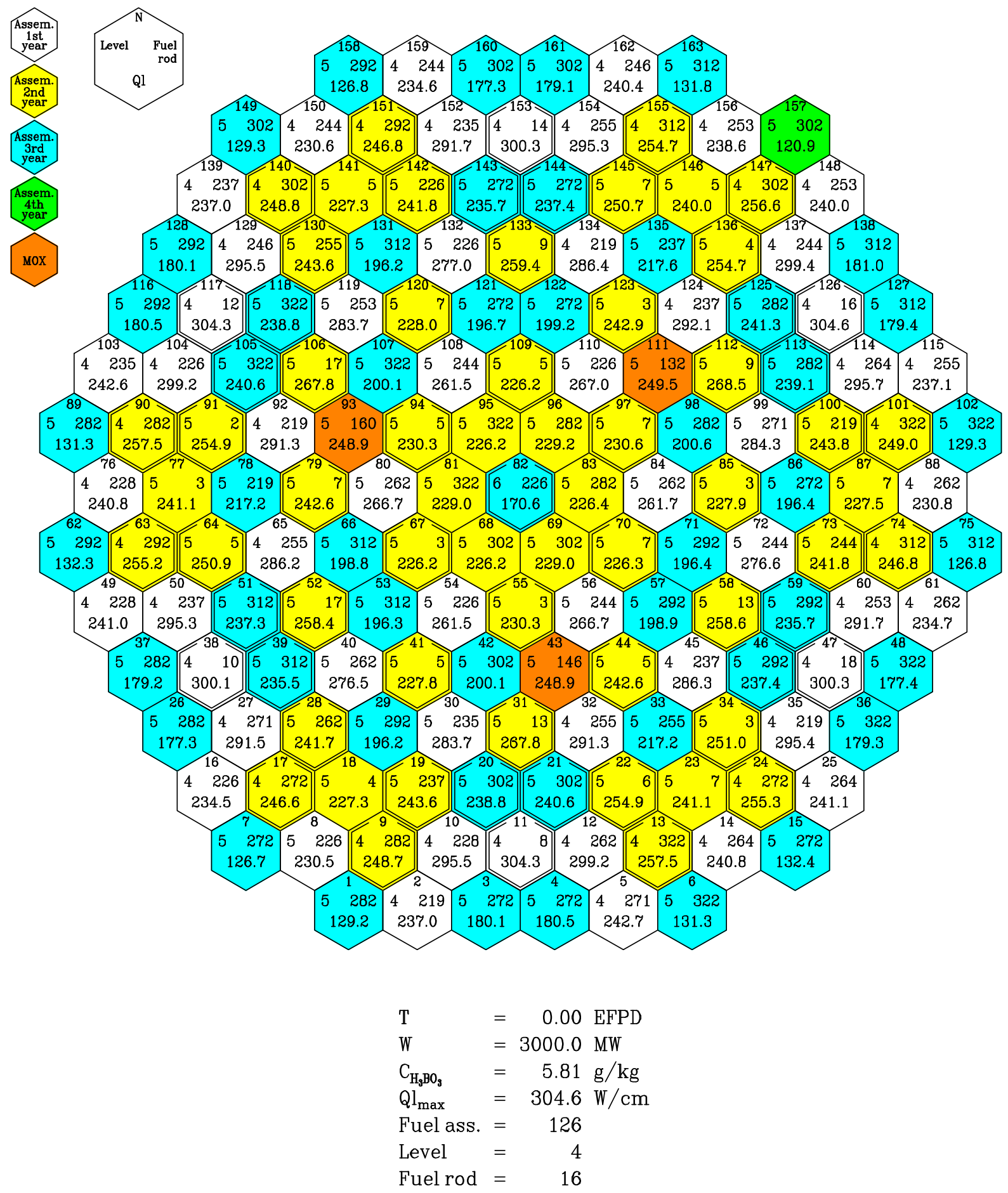


RUSSIAN RESEARCH CENTER KURCHATOV INSTITUTE

Kinetics Parameters of VVER-1000 Core with 3 MOX Lead Test Assemblies to be used for Accident Analysis Codes

Fig.57. Assembly-by-Assembly Maximum Linear Pin Power Distribution in EOC. Third Cycle with 3 MOX LTAs 100\%Pu (4.2-3.0-2.0)

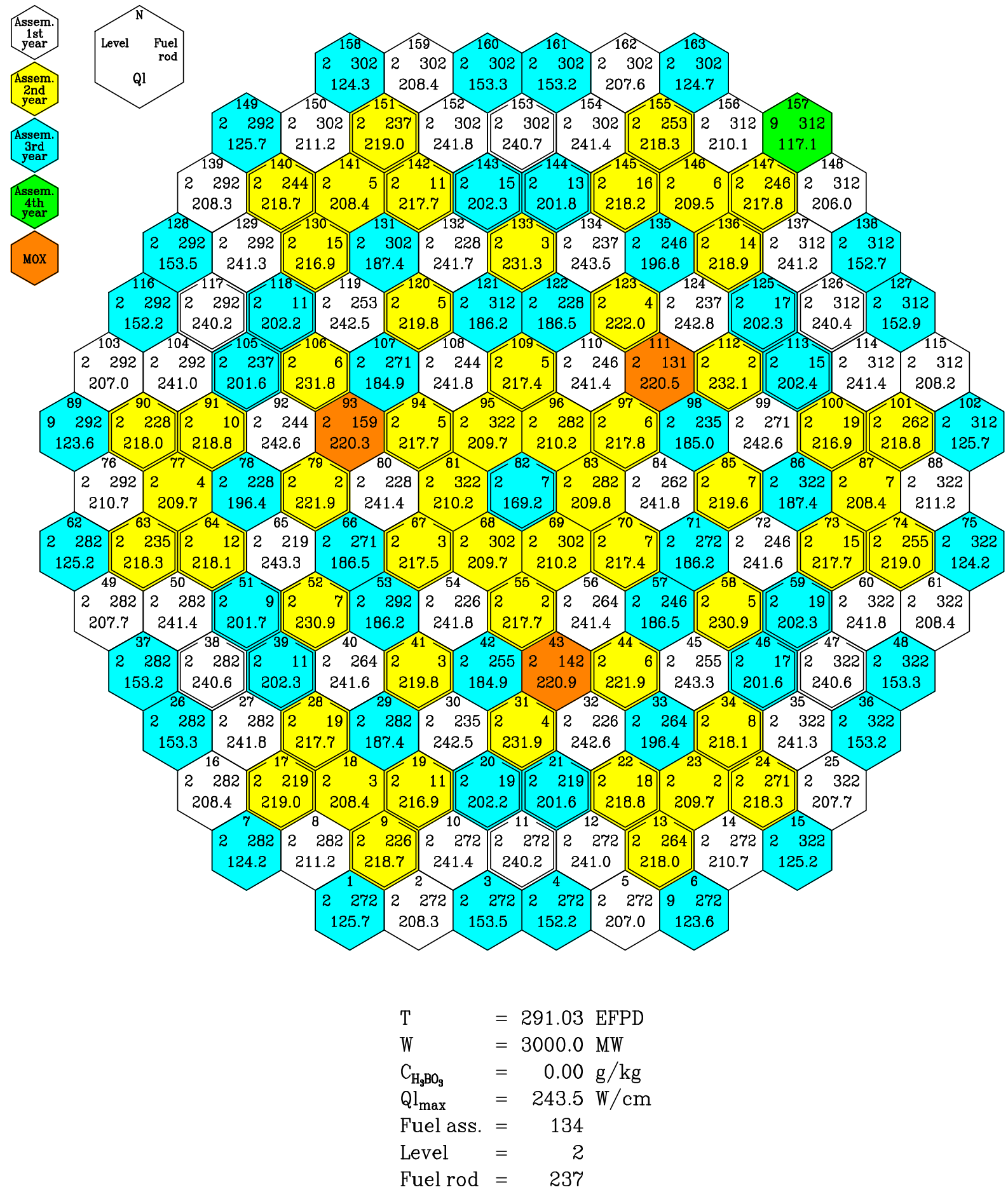


RUSSIAN RESEARCH CENTER KURCHATOV INSTITUTE

Kinetics Parameters of VVER-1000 Core with 3 MOX Lead Test Assemblies to be used for Accident Analysis Codes

Fig.58. Pin-by-Pin Power Distribution in the Most Powered Assembly in BOC. Third Cycle with 3 MOX LTAs 100\%Pu (4.2-3.0-2.0)

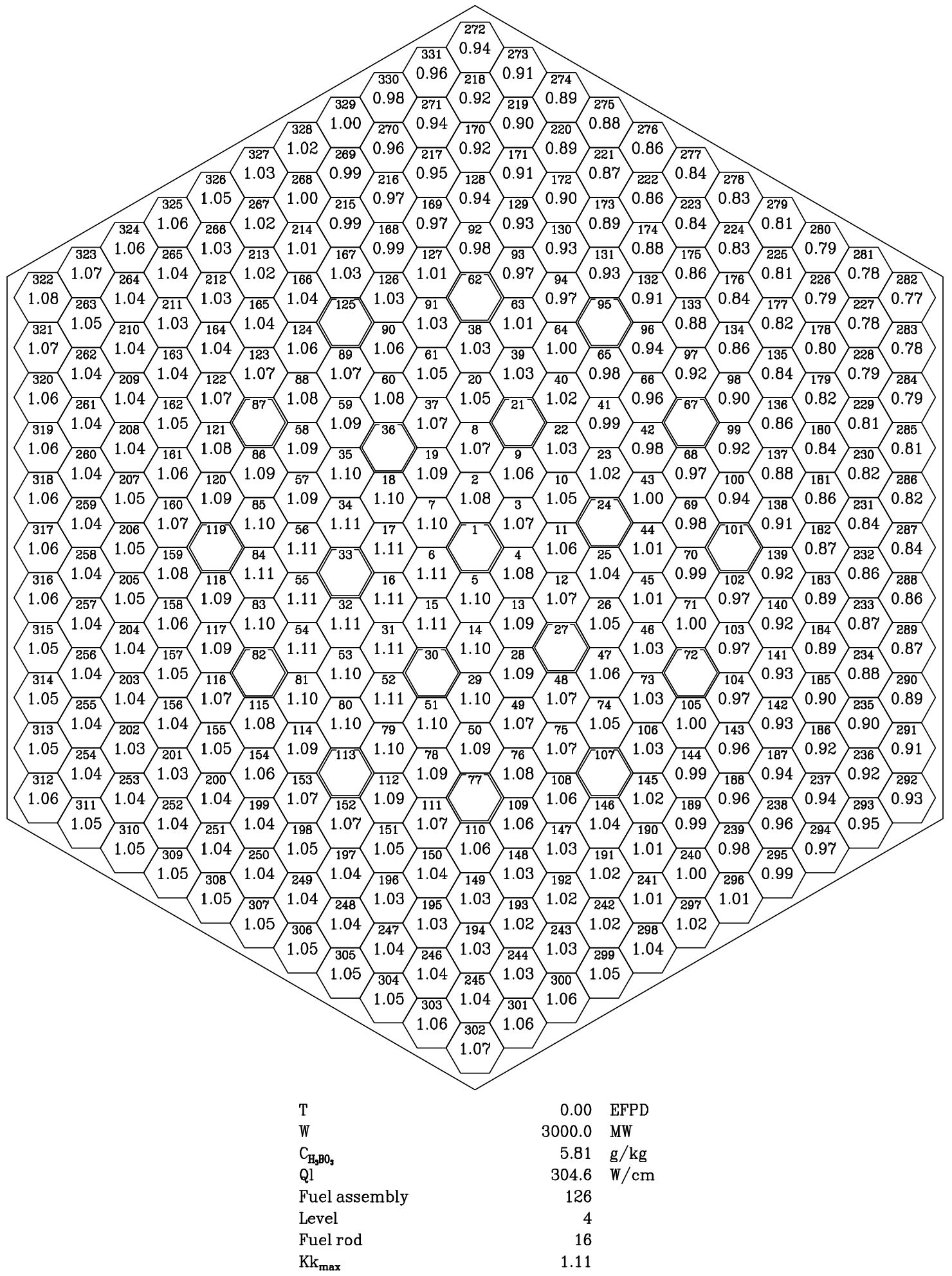


RUSSIAN RESEARCH CENTER KURCHATOV INSTITUTE

Kinetics Parameters of VVER-1000 Core with 3 MOX Lead Test Assemblies to be used for Accident Analysis Codes

Fig.59. Pin-by-Pin Power Distribution in the Most Powered Assembly in EOC. Third Cycle with 3 MOX LTAs $100 \%$ Pu (4.2-3.0-2.0)

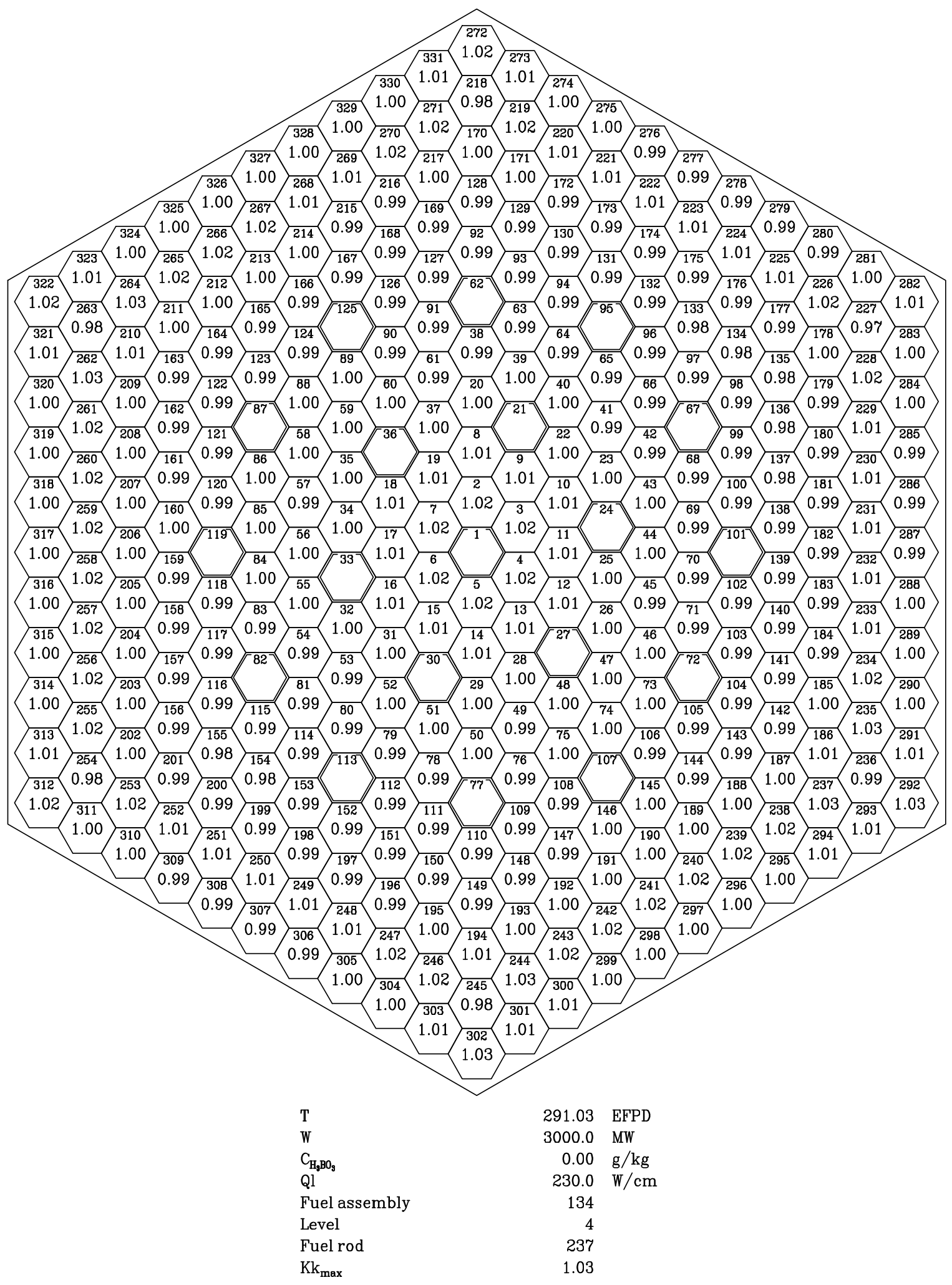


RUSSIAN RESEARCH CENTER KURCHATOV INSTITUTE

Kinetics Parameters of VVER-1000 Core with 3 MOX Lead Test Assemblies to be used for Accident Analysis Codes

Fig.60. Pin-by-Pin Power Distribution in MOX LTA in BOC. Third Cycle with 3 MOX LTAs $100 \%$ Pu (4.2-3.0-2.0)

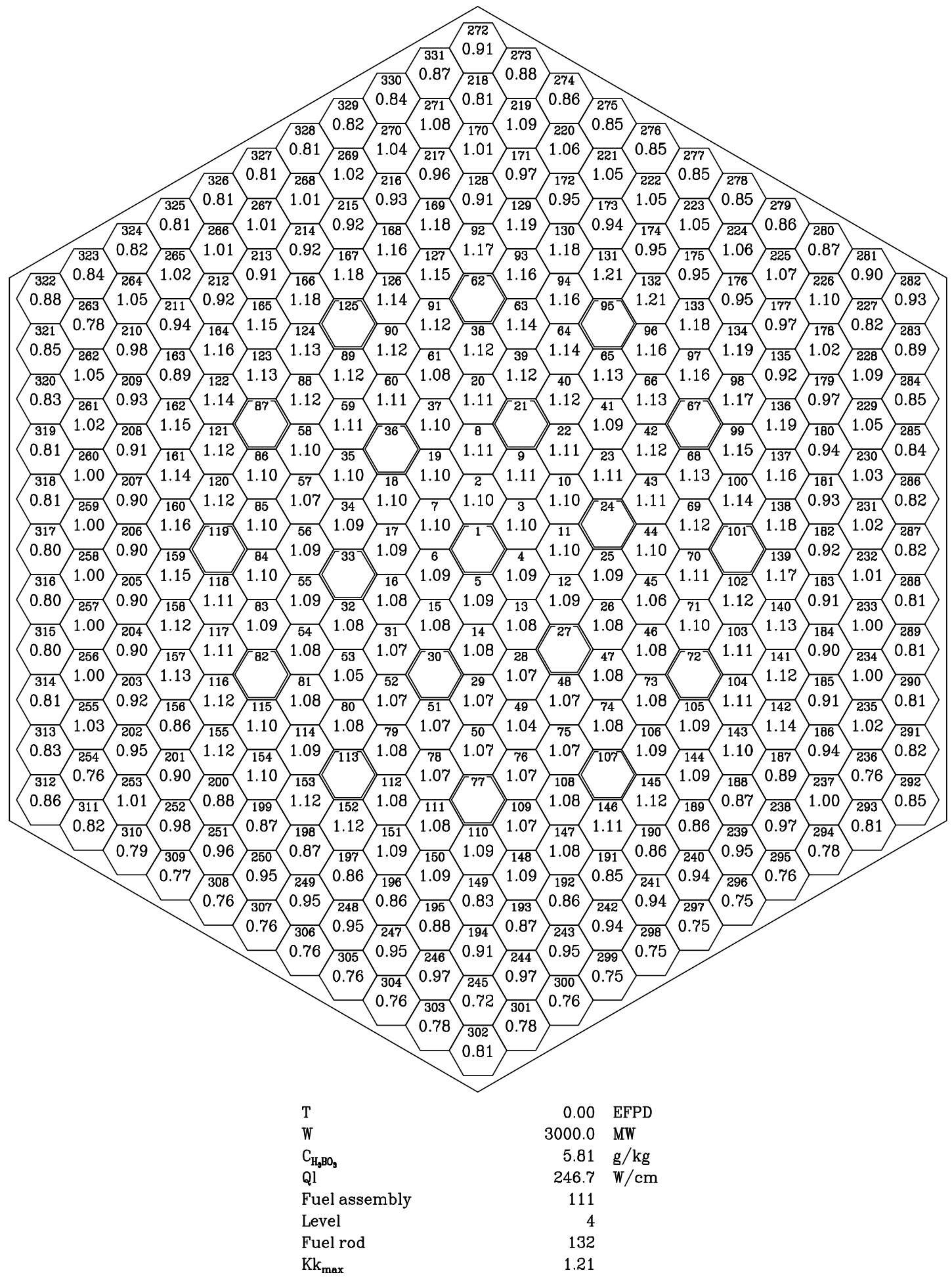


RUSSIAN RESEARCH CENTER KURCHATOV INSTITUTE

Kinetics Parameters of VVER-1000 Core with 3 MOX Lead Test Assemblies to be used for Accident Analysis Codes

Fig.61. Pin-by-Pin Power Distribution in MOX LTA in EOC. Third Cycle with 3 MOX LTAs 100\%Pu (4.2-3.0-2.0)

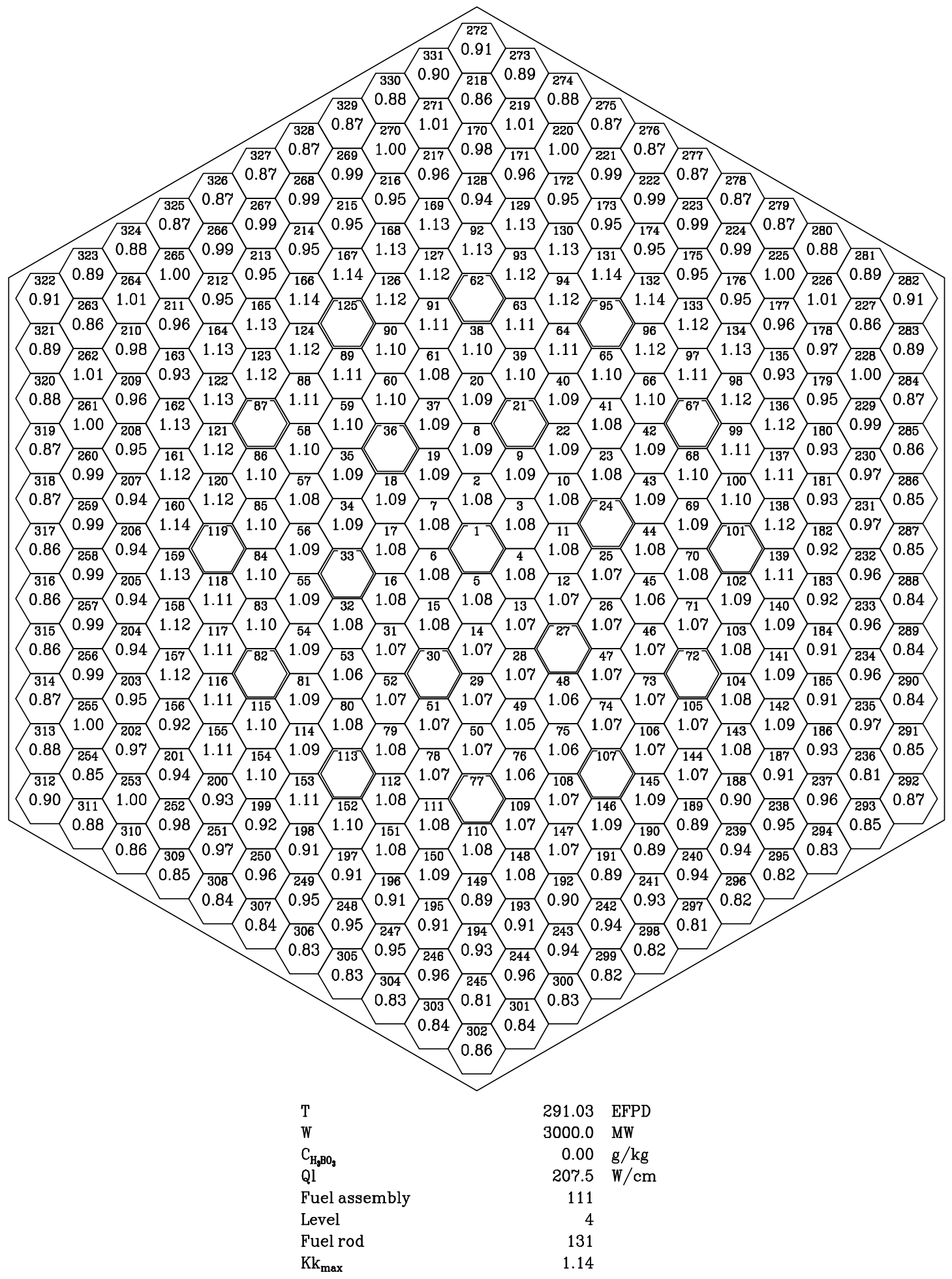


RUSSIAN RESEARCH CENTER KURCHATOV INSTITUTE

Kinetics Parameters of VVER-1000 Core with 3 MOX Lead Test Assemblies to be used for

Accident Analysis Codes

Fig.62. Assembly-by-Assembly Power Distribution.

Third Cycle with 3 MOX LTAs of "Island" Type (Pu3.8-2.8-U3.7)

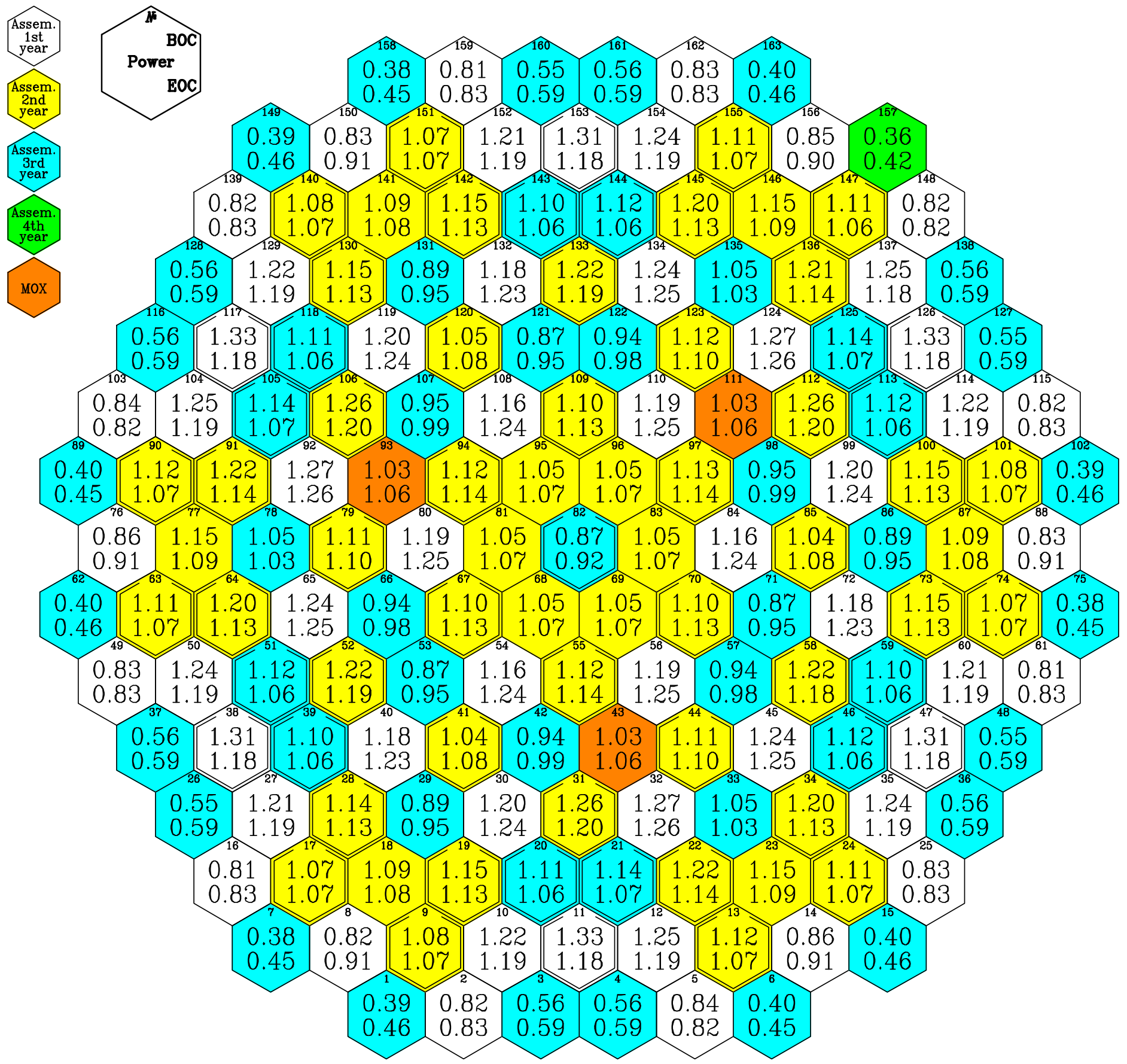


RUSSIAN RESEARCH CENTER KURCHATOV INSTITUTE

Kinetics Parameters of VVER-1000 Core with 3 MOX Lead Test Assemblies to be used for

Accident Analysis Codes

Fig.63. Assembly-by-Assembly Burnup Distribution.

Third Cycle with 3 MOX LTAs of "Island" Type (Pu3.8-2.8-U3.7)

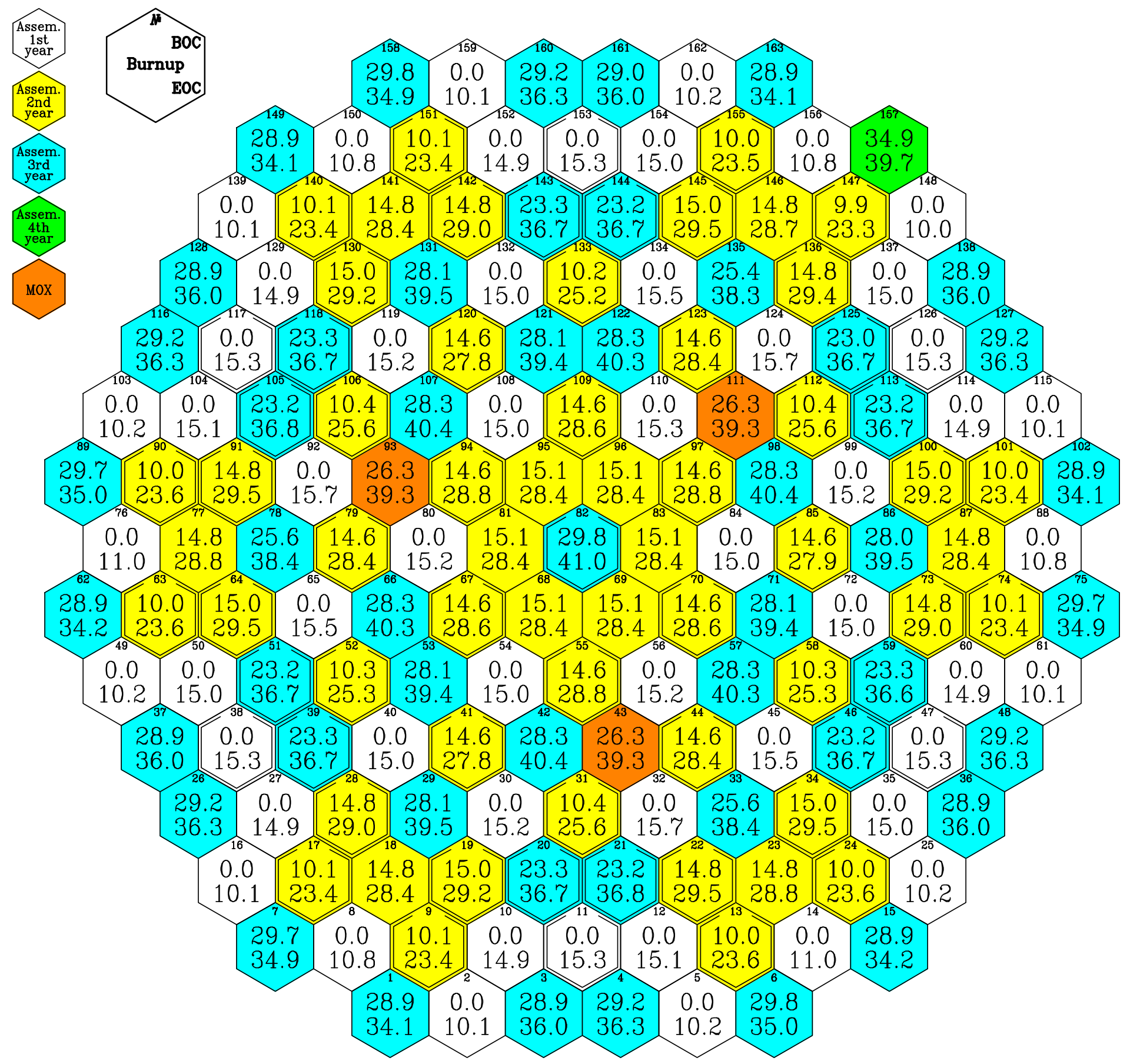


RUSSIAN RESEARCH CENTER KURCHATOV INSTITUTE

Kinetics Parameters of VVER-1000 Core with 3 MOX Lead Test Assemblies to be used for

Accident Analysis Codes

Fig.64. Assembly-by-Assembly Temperature Drop Distribution. Third Cycle with 3 MOX LTAs of "Island" Type (Pu3.8-2.8-U3.7)

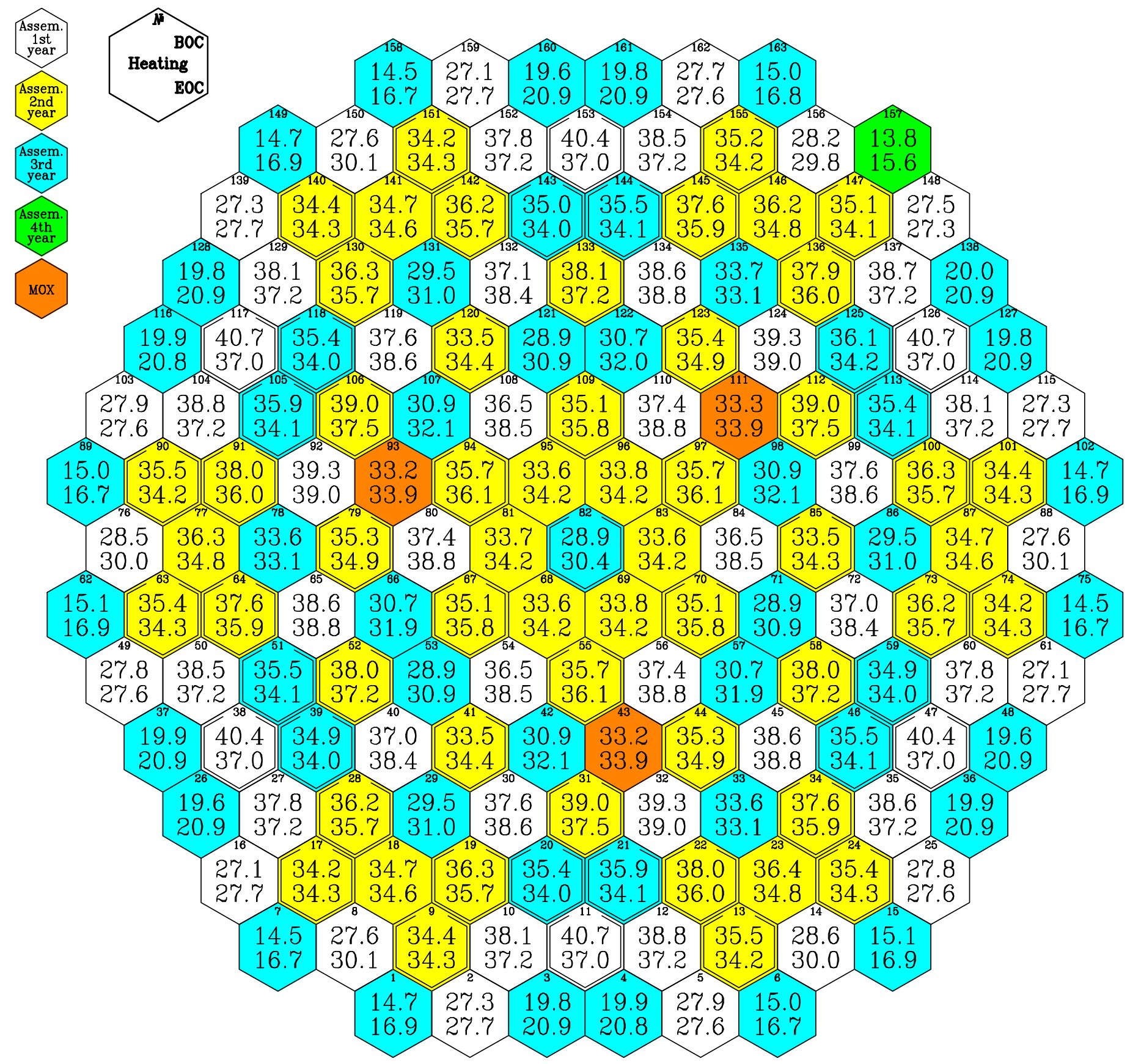


RUSSIAN RESEARCH CENTER KURCHATOV INSTITUTE

Kinetics Parameters of VVER-1000 Core with 3 MOX Lead Test Assemblies to be used for Accident Analysis Codes

Fig.65. Assembly-by-Assembly Maximum Linear Power Distribution in BOC. Third Cycle with 3 MOX LTAs of "Island" Type (Pu3.8-2.8-U3.7)

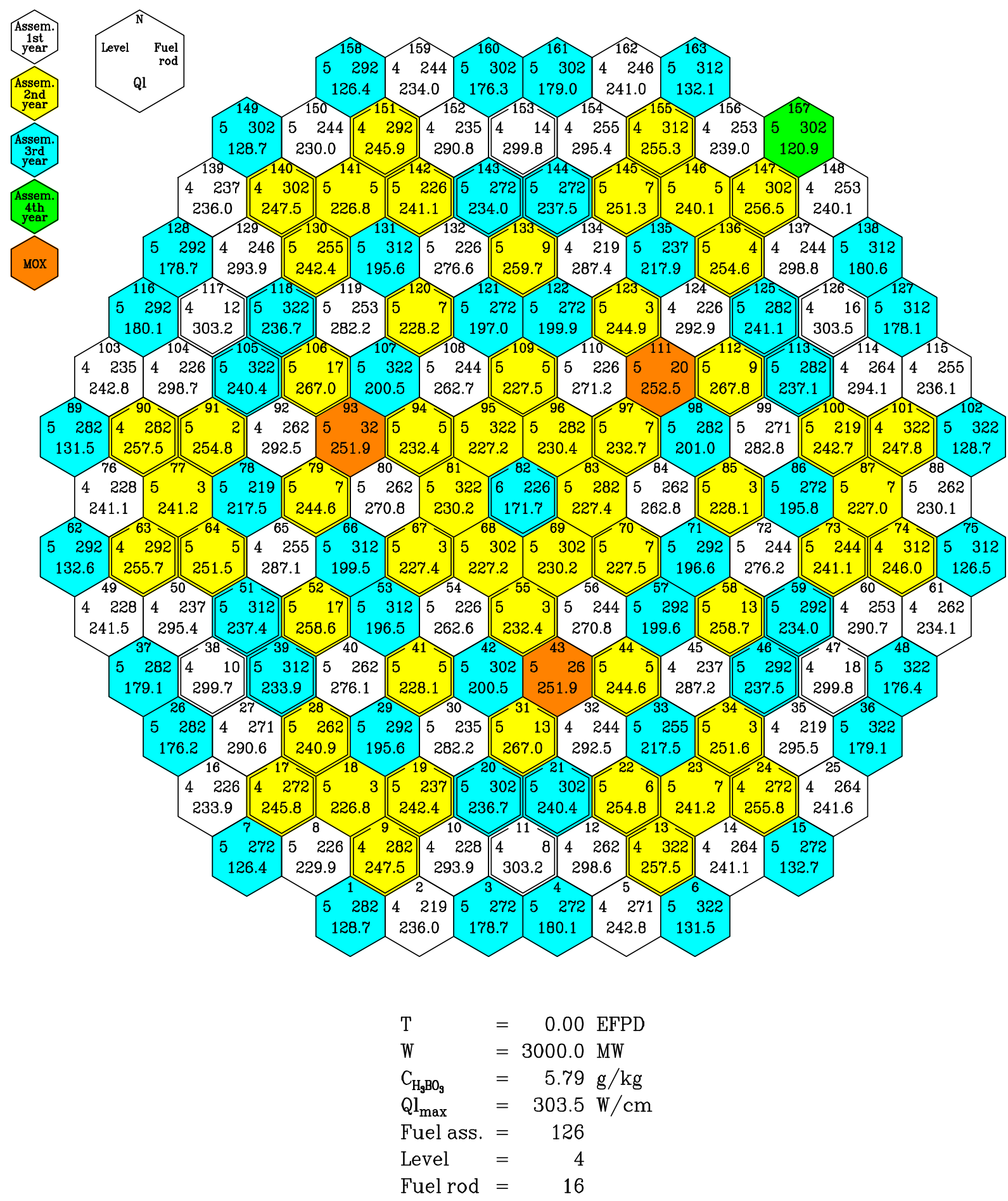


RUSSIAN RESEARCH CENTER KURCHATOV INSTITUTE

Kinetics Parameters of VVER-1000 Core with 3 MOX Lead Test Assemblies to be used for Accident Analysis Codes

Fig.66. Assembly-by-Assembly Maximum Linear Power Distribution in EOC. Third Cycle with 3 MOX LTAs of "Island" Type (Pu3.8-2.8-U3.7)

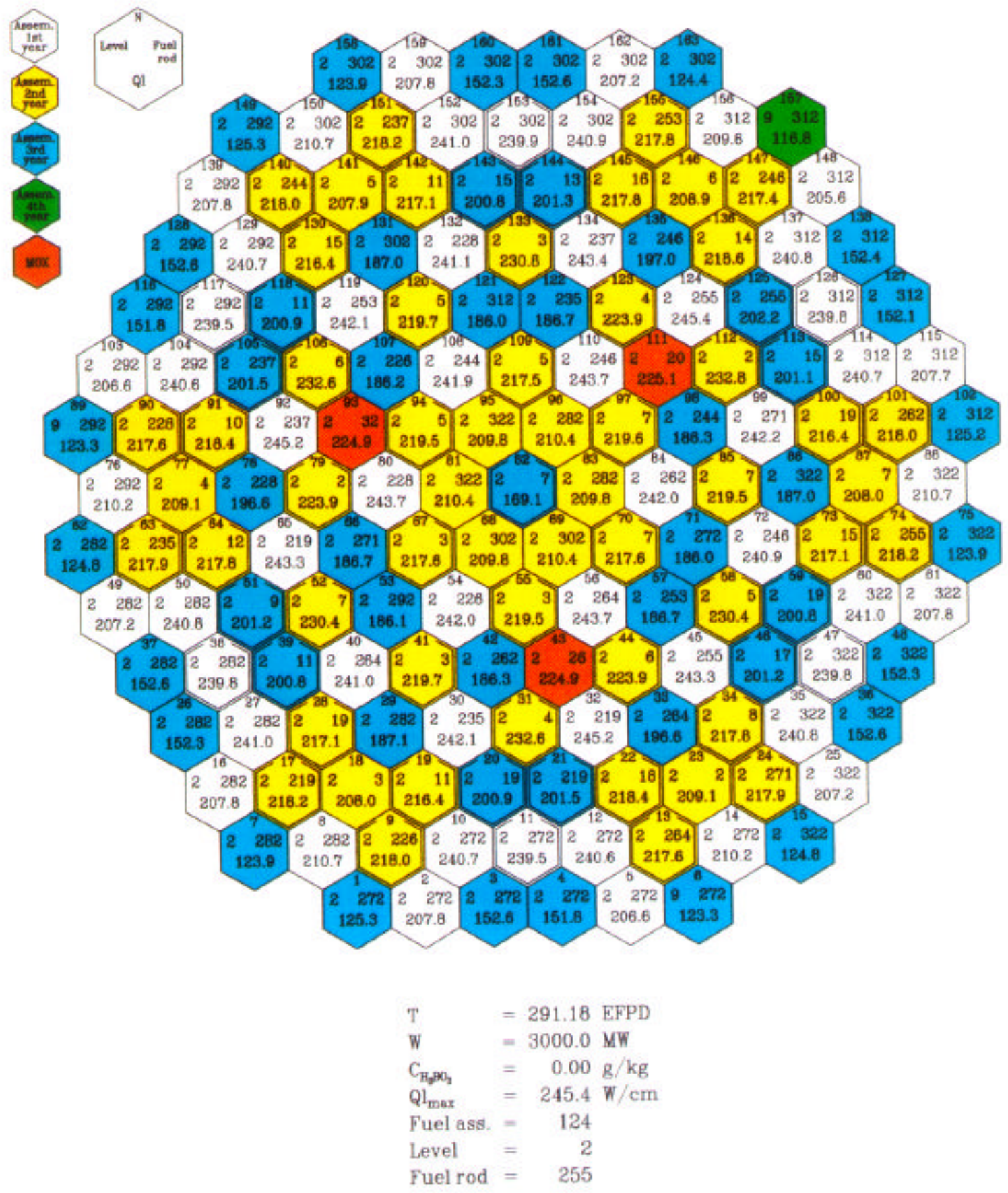


RUSSIAN RESEARCH CENTER KURCHATOV INSTITUTE

Kinetics Parameters of VVER-1000 Core with 3 MOX Lead Test Assemblies to be used for Accident Analysis Codes

Fig.67. Pin-by-Pin Power Distribution in the Most Powered Assembly in BOC. Third Cycle with 3 MOX LTAs of "Island" Type ( Pu3.8-2.8-U3.7)

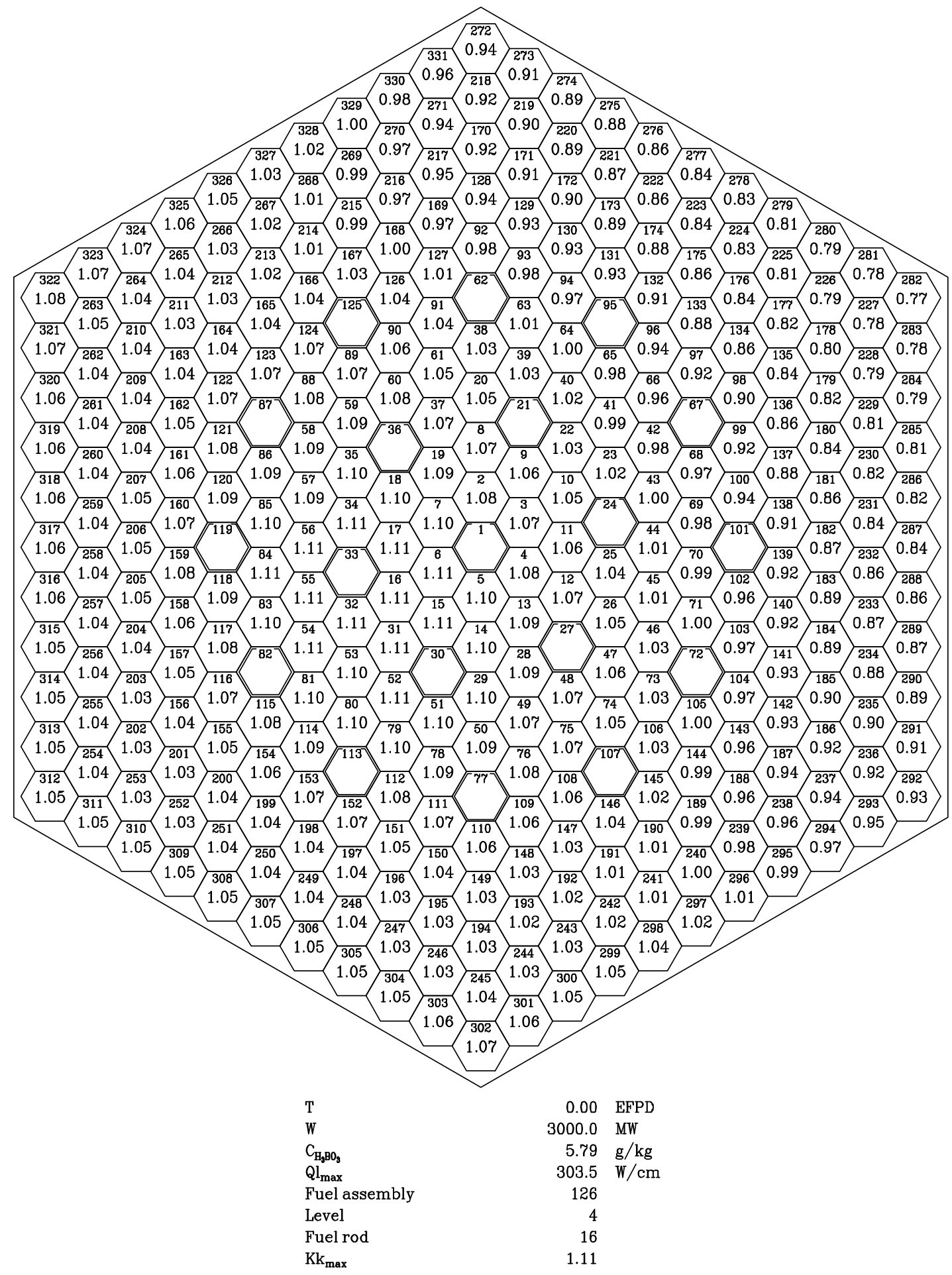


RUSSIAN RESEARCH CENTER KURCHATOV INSTITUTE

Kinetics Parameters of VVER-1000 Core with 3 MOX Lead Test Assemblies to be used for Accident Analysis Codes

Fig.68. Pin-by-Pin Power Distribution in the Most Powered Assembly in EOC. Third Cycle with 3 MOX LTAs of "Island" Type ( Pu3.8-2.8-U3.7)

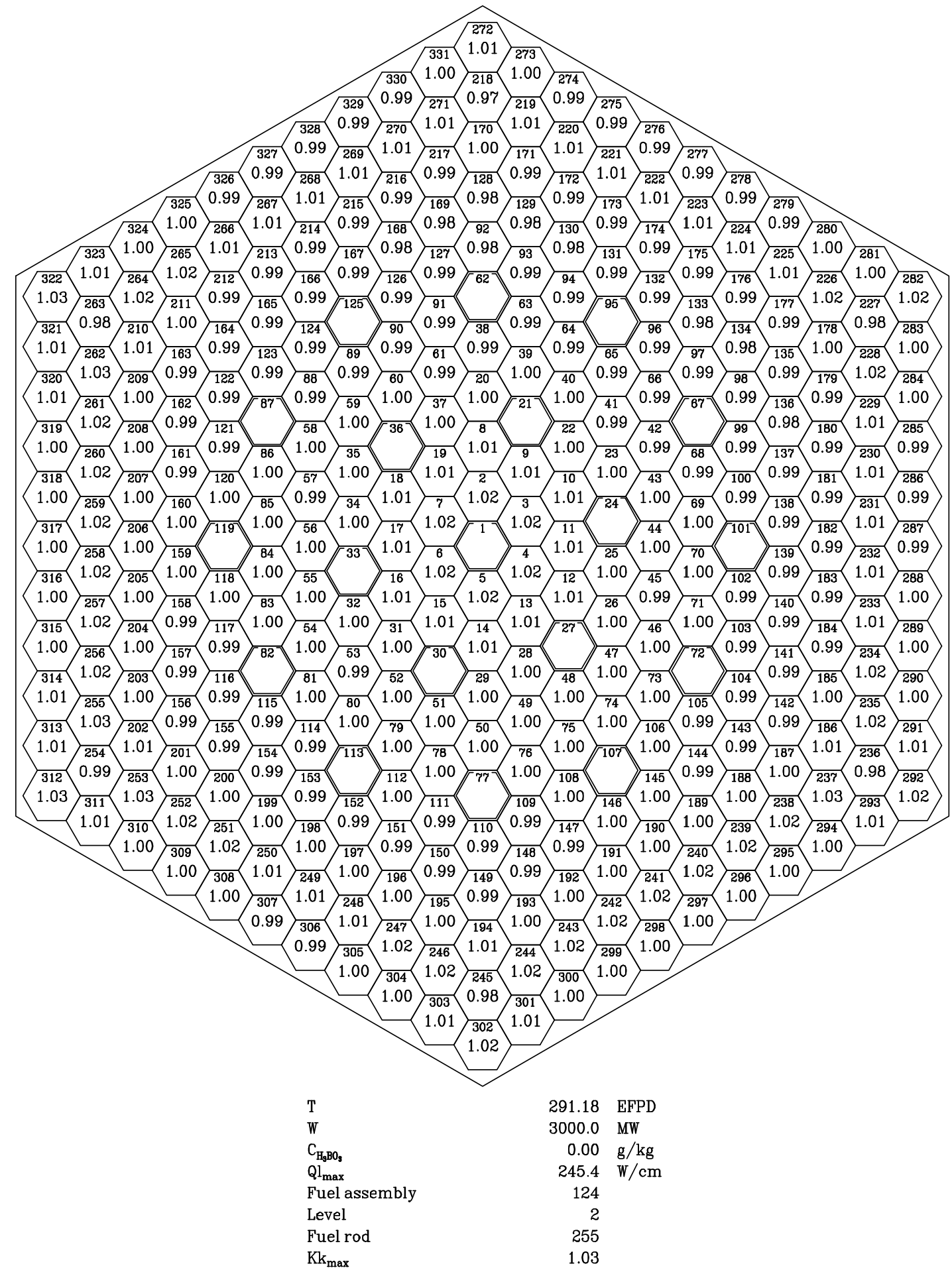


RUSSIAN RESEARCH CENTER KURCHATOV INSTITUTE

Kinetics Parameters of VVER-1000 Core with 3 MOX Lead Test Assemblies to be used for Accident Analysis Codes

Fig.69. Pin-by-Pin Power Distribution in MOX LTA in BOC. Third Cycle with 3 MOX LTAs of "Island" Type ( Pu3.8-2.8-U3.7)

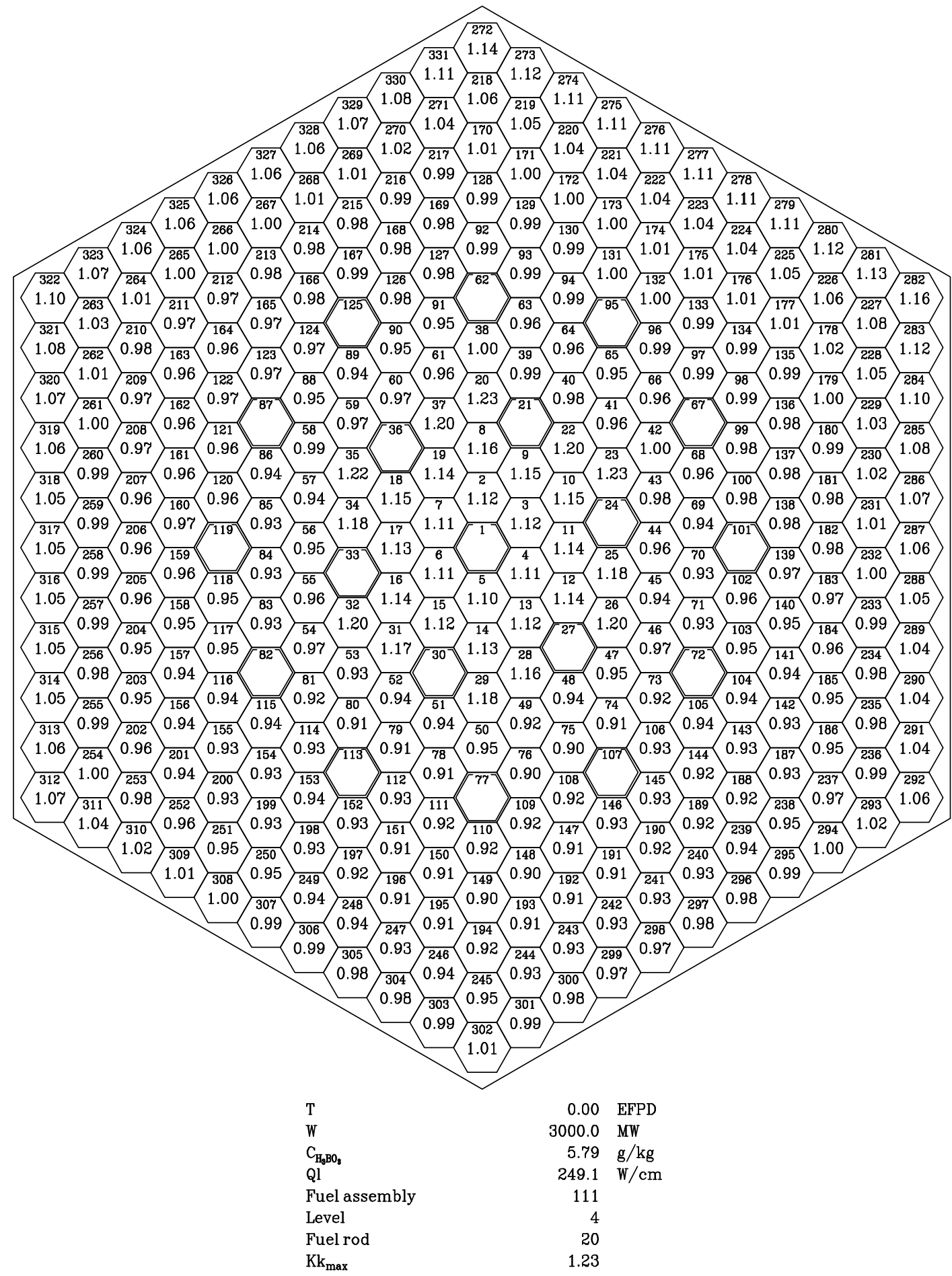


RUSSIAN RESEARCH CENTER KURCHATOV INSTITUTE

Kinetics Parameters of VVER-1000 Core with 3 MOX Lead Test Assemblies to be used for Accident Analysis Codes

Fig.70. Pin-by-Pin Power Distribution in MOX LTA in EOC. Third Cycle with 3 MOX LTAs of "Island" Type ( Pu3.8-2.8-U3.7)

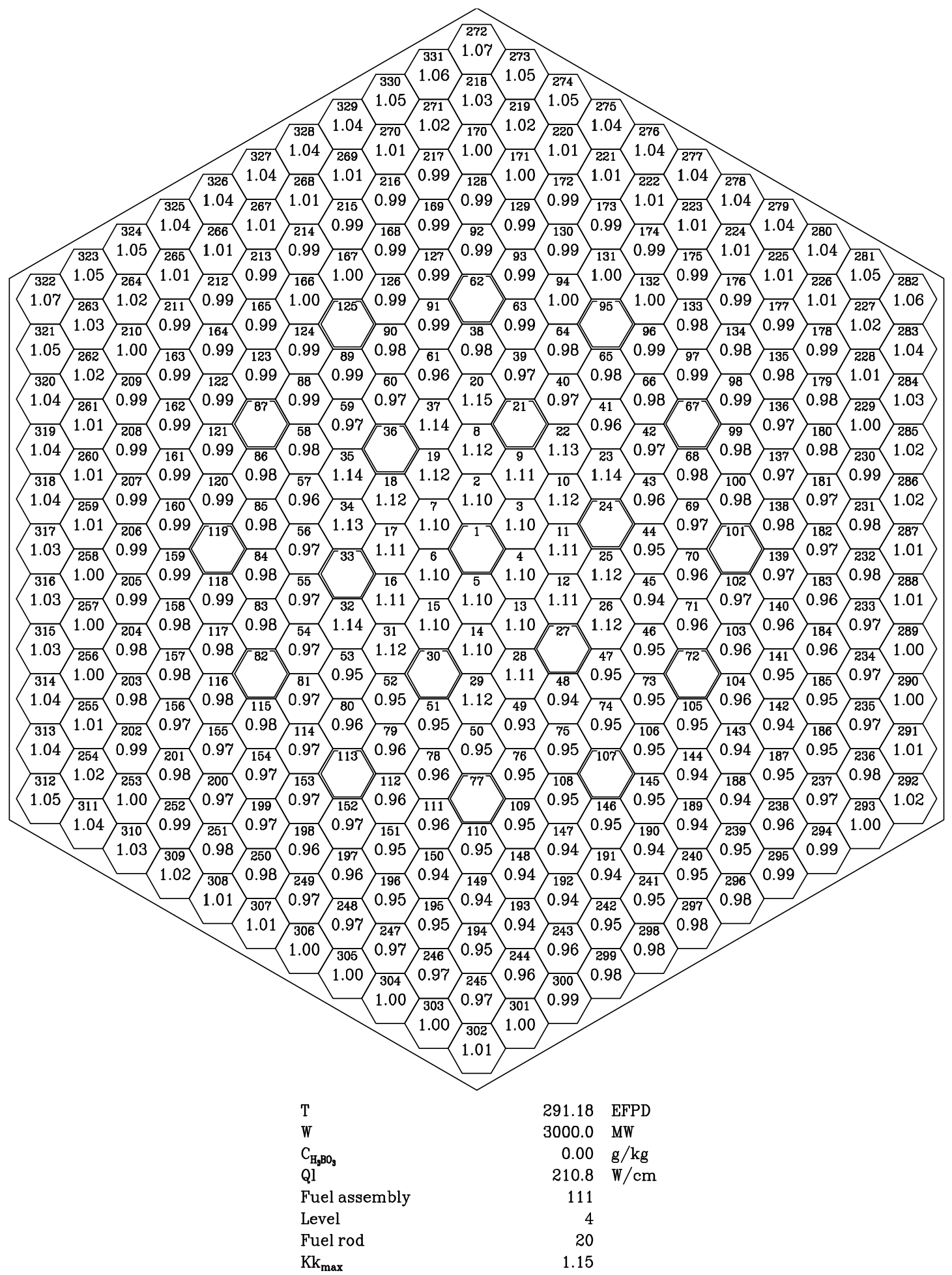


124 
Comments from ORNL staff on the report, Kinetics Parameters of VVER-1000 Core with 3 MOX Lead Test Assemblies to be used for Accident Analysis Codes

1. Page 18: The notations for the Xe and Sm concentrations are ambiguous. The units are noted as $10^{24}$ per cubic centimeter, but the comment notes that the element symbol value refers to different states of the core, i.e., fission product poison is absent, equilibrium. Since the Xe and Sm content of 1 cubic centimeter of fuel could never be equal or greater than $1\left(10^{24}\right)$ for reactor conditions, it is assumed that if the value is less than 1 , the interpretation is units of $10^{24}$ per cubic centimeter, but if equal to or greater than 1 , the interpretation is as noted in the comments column.

2. Page 62, Fig. 9: The axial levels in this and subsequent figures correspond to those in Table 18 (level $4=124.25 \mathrm{~cm}$, level $2=53.25 \mathrm{~cm}$, etc.).

3. Page 28-4, Tables 3-9: The symbol given for the prompt neutron lifetime $\left(1_{\mathrm{im}}\right)$ does not match that given in Table 1 ( $\lambda_{\mathrm{im}}$, i.e. $\left.\mathrm{lamba}_{\mathrm{im}}\right)$ but is assumed to be intended to be the same.

4. Page 24, Table 2: From the magnitude of the boron reactivity coefficient given here it appears that its units are $\mathrm{pcm} / \mathrm{ppm}$-boron, while the values given in Tables 3-9 appear to be $\mathrm{pcm} / \mathrm{ppm}$-boric acid (as noted in Table 1). The reader should note that the values in Table 2 are not provided with units consistent with similar values reported elsewhere in the report.

5. The axial location $\mathrm{z}=0$ is at the bottom of the fueled region of the core. Note that in the axial power distribution figures ( 7 and $7 \mathrm{a}$ ), the values for the bottom of the core are at the right of the figure.

6. This report is the deliverable for FY 1999 Annual Operating Plan Task 10.2.2.1, milestone e. This milestone also had the internal ORNL designation of 99-2. 
ORNL/SUB/99-B99398V-2

\section{INTERNAL DISTRIBUTION}

$\begin{aligned} 1-5 . & \text { B. B. Bevard } \\ 6 . & \text { J. J. Carbajo } \\ 7 . & \text { E. D. Collins } \\ 8 . & \text { B. S. Cowell } \\ 9 . & \text { M. D. DeHart } \\ \text { 10. } & \text { F. C. Difilippo } \\ 11 . & \text { R. J. Ellis } \\ 12-16 . & \text { J. C. Gehin } \\ 17 . & \text { S. R. Greene } \\ \text { 18. } & \text { T. W. Horning } \\ 19 . & \text { D. T. Ingersoll }\end{aligned}$

\author{
20. M. A. Kuliasha \\ 21. G. E. Michaels \\ 22. B. D. Murphy \\ 23. D. L. Moses \\ 24. C. V. Parks \\ 25-29. R. T. Primm III \\ 30. C. C. Southmayd \\ 31. Central Research Library \\ 32-33. ORNL Laboratory Records (OSTI) \\ 34. ORNL Laboratory Records-RC
}

\section{EXTERNAL DISTRIBUTION}

35. N. Abdurrahman, College of Engineering, Dept. of Mechanical Engineering, University of Texas, Austin, TX 78712

36. M. L. Adams, Department of Nuclear Engineering, Texas A\&M University, Zachry 129, College Station, TX 77843

37. D. Alberstein, Los Alamos National Laboratory, MS-E502, P.O. Box 1663, Los Alamos, NM 87545

38. J. Baker, Office of Fissile Materials Disposition, U.S. Department of Energy, MD-3, 1000 Independence Avenue SW, Washington, DC 20585

39. J. B. Briggs, Idaho National Environmental and Engineering Laboratory, P.O. Box 16253855, Idaho Falls, ID 83415-3855

40. L. Holgate, Office of Fissile Materials Disposition, U.S. Department of Energy, MD-1/2, 1000 Independence Avenue SW, Washington DC 20585

41. N. Fletcher, Office of Fissile Materials Disposition, U.S. Department of Energy, MD-3, 1000 Independence Avenue SW, Washington DC 20585

42. K. Chidester, Los Alamos National Laboratory, MS-E502, P.O. Box 1663, Los Alamos, NM 87545

43. W. Danker, U. S. Department of Energy, MD-3, 1000 Independence Avenue SW, Washington DC 20585

44. T. Gould, Lawrence Livermore National Laboratory, P.O. Box 808, MS-L186, Livermore, CA 94551

45. L. Jardine, Lawrence Livermore National Laboratory, P.O. Box 808, MS-L166, Livermore, CA 94551

46. Dr. Alexander Kalashnikov, Institute of Physics and Power Engineering, 1 Bondarenko Square, Obninsk, Kaluga Region, Russia 249020

47-51. D. E. Klein, Associate Vice Chancellor for Special Engineering Programs, The University of Texas System, 210 West Sixth Street, Austin, TX 78701

52. J. O. Nulton, Office of Fissile Materials Disposition, U.S. Department of Energy, MD-3, 1000 Independence Avenue SW, Washington, DC 20585

53. Dr. Stephen L. Passman, Sandia National Laboratories, Suite 110, 950 L'Enfant Plaza, S.W., Washington DC 20024-2123 
54-58. Dr. Alexander Pavlovitchev, Russian Research Center "Kurchatov Institute," Institute of Nuclear Reactors VVER Division, VVER Physics Department, 123182, Kurchatov Square, 1, Moscow, Russia

59. K. L. Peddicord, Associate Vice Chancellor, Texas A\&M University, 120 Zachry, College Station, TX 77843-3133

60. W. D. Reece, Texas A\&M University, Department of Nuclear Engineering, Zachry 129, College Station, TX 77843-3133

61. R. H. Clark, Duke Cogema Stone \& Webster, 400 South Tryon Street, WC-32G, P.O. Box 1004, Charlotte, NC 28202

62. S. Nesbit, Duke/Cogema/Stone \& Webster, 400 South Tryon Street, WC-32G, P.O. Box 1004, Charlotte, NC 28202

63. D. Dziadosz, Innsbruck Technical Center, 5000 Dominion Blvd., Glen Allen, VA 23060

64. M. S. Chatterton, Office of Nuclear Reactor Regulation, MS O10B3, U.S. Nuclear Regulatory Commission, Washington, DC 20555-0001

65. U. Shoop, Office of Nuclear Reactor Regulation, MS O10B3, U.S. Nuclear Regulatory Commission, Washington, DC 20555-0001 